UNIVERSIDADE DE SÃO PAULO

FACULDADE DE FILOSOFIA, LETRAS E CIÊNCIAS HUMANAS DEPARTAMENTO DE LETRAS CLÁSSICAS E VERNÁCULAS PROGRAMA DE PÓS-GRADUAÇÃO EM LITERATURA BRASILEIRA

\title{
ALUÍSIO AZEVEDO: O MOVIMENTO CRIATIVO DE CASA DE PENSÃO
}

MARIZETE LIAMAR GRANDO GARCIA 
MARIZETE LIAMAR GRANDO GARCIA

\section{ALUÍSIO AZEVEDO: O MOVIMENTO CRIATIVO DE CASA DE PENSÃO}

Tese apresentada ao Programa de Pós-Graduação em Literatura Brasileira, do Departamento de Letras Clássicas e Vernáculas da Faculdade de Filosofia, Letras e Ciências Humanas da Universidade de São Paulo, Como exigência para a obtenção do título de Doutor em Letras.

Orientador: Prof. Dr. José Alcides Ribeiro 
Ao meu pai Rubi e à minha mãe Nilce, pelo exemplo de força e integridade e também porque sempre acreditaram em mim. Ao meu marido Cássio, pela cumplicidade, apoio e amor incondicional. 


\section{AGRADECIMENTOS}

Inicialmente, agradeço ao Prof. Dr. José Alcides, orientador deste trabalho, pelo profissionalismo, leitura e seriedade durante o desenvolvimento desta tese.

Ao Prof. Dr. Amalio Pinheiro e ao Prof. Dr. José Luiz Proença, pelas sugestões e caminhos apontados durante o exame de qualificação.

Ao Prof. Dr. Jaime Ginzburg e à Profa. Dra. Cilaine Cunha, pelo apoio e amizade.

Ao Conselho Nacional de Desenvolvimento Científico e Tecnológico (CNPq), pelo auxílio financeiro à pesquisa.

À Profa. Ms. Maria Albany da Costa, por ter me ensinado a dar os primeiros passos no caminho das letras e que, quinze anos depois, honra-me com a leitura minuciosa da minha tese. Albany, você representa um marco na minha vida acadêmica, a inspiração que me fez acreditar que o mundo pode ser bem melhor para aqueles que lutam e vencem os obstáculos.

Aos funcionários da Biblioteca Nacional - Rio de Janeiro, especialmente à Anna Naldi, pelo auxílio durante a pesquisa documental.

Sou grata especialmente aos meus pais que, apesar de terem pouco estudo, são dois sábios que me ensinaram a encontrar em mim a resposta para tudo. Por eles eu me fiz forte para vencer o mundo e a ser muito mais do que o que destruiu parte das minhas ilusões.

Aos meus irmãos, Carlos, Sidnei, Janete e Vitor, pela compreensão e carinho. Aos cunhados Dilso, Shirley, Alice e Thaysa, pela amizade. Aos meus sobrinhos Suelen, Luís Eduardo, Gabriel, Emmanuel, Maria Eduarda, José Felipe e João Vitor.

Ao Cássio, por entender a necessidade que eu tive de dedicar grande parte do meu tempo à pesquisa; por sempre estar ao meu lado e sorrir, tornando a vida mais leve, como um conto de fadas.

À família Moret e Garcia, pelo apoio.

Aos amigos Marco, Iliene, Beth e Júlio Peruzzi; Alessandro e Lígia; Nelson; 
Elisângela; Dami, pela cumplicidade.

Agradeço a todos os meu colegas da USP, que estiverem ao meu lado em diversos momentos dos anos dedicados a esta pesquisa.

Mais uma vez, agradeço a Deus, por tudo. 
Já é madrugada, a luz da minha luminária te deixa inquieto, apago-a, guardo as seqüências do romance-seriado, você continua agitado, mexe-se muitas vezes, até que sua cabeça sai do travesseiro e caí sobre o livro Casa de Pensão... Preciso pegar o livro... Deveria desligar o computador, mas é necessário voltar à leitura do capítulo sete. Como falta apenas uma seqüência, irei escrever na sala e levarei o livro e o romance-seriado comigo. Durma bem querido Cássio, pois hoje preciso entender um pouco mais o meu Aluísio. 


\section{SUMÁRIO}

$\begin{array}{ll}\text { RESUMO } & 14\end{array}$

$\begin{array}{ll}\text { ABSTRACT } & 15\end{array}$

INTRODUÇÃO 16

1 TÉCNICAS DE ROMANCE-SERIADO 28

1.1 Capítulo I - dois segmentos 34

1.1.1 Primeira seqüência: 06 de março (1) 34

1.1.1.1 Principais ações desta seqüência 35

1.1.1.2 Técnicas básicas do padrão narrativo do romance-seriado 36

1.1.2 Segunda seqüência: 07 de março (2) 36

1.1.2.1 Principais ações desta seqüência 36

1.1.2.2 Técnicas básicas do padrão narrativo do romance-seriado 37

1.2 Capítulo II - quatro segmentos 38

1.2.1 Primeira seqüência: 08 de março (2) 38

1.2.1.1 Principais ações desta seqüência 38

1.2.1.2 Técnicas básicas do padrão narrativo do romance-seriado 39

1.2.2 Segunda seqüência: 09 de março (4) 40

1.2.2.1 Principais ações desta seqüência $\quad 40$

1.2.2.2 Técnicas básicas do padrão narrativo do romance-seriado 41

1.2.3 Terceira seqüência: 10 de março (5) 42

1.2.3.1 Principais ações desta seqüência 42

1.2.3.2Técnicas básicas do padrão narrativo do romance-seriado 43

1.2.4 Quarta seqüência: 11 de março (6) 43 
1.2.4.1 Principais ações desta seqüência

1.2.4.2Técnicas básicas do padrão narrativo do romance-seriado

1.3 Capítulo III - cinco segmentos

1.3.1 Primeira seqüência: 12 de março (7)

1.3.1.1 Principais ações desta seqüência

1.3.1.2Técnicas básicas do padrão narrativo do romance-seriado

1.3.2 Segunda seqüência: 14 de março (8)

1.3.2.1 Principais ações desta seqüência

1.3.2.2 Técnicas básicas do padrão narrativo do romance-seriado

1.3.3 Terceira seqüência: 15 de março (9)

1.3.3.1 Principais ações desta seqüência

1.3.3.2 Técnicas básicas do padrão narrativo do romance-seriado

1.3.4 Quarta seqüência: 16 de março (10)

1.3.4.1 Principais ações desta seqüência

1.3.4.2 Técnicas básicas do padrão narrativo do romance-seriado

1.3.5 Quinta seqüência: 17 de março (11)

1.3.5.1 Principais ações desta seqüência

1.3.5.2 Técnicas básicas do padrão narrativo do romance-seriado

1.4 Capítulo IV - dois segmentos

1.4.1 Primeira segunda seqüência: 20 de março (12)

1.4.1.1 Principais ações desta seqüência

1.4.1.2 Técnicas básicas do padrão narrativo do romance-seriado

1.4.2 Segunda seqüência: 21 de março (13)

1.4.2.1 Principais ações desta seqüência 56

1.4.2.2 Técnicas básicas do padrão narrativo do romance-seriado 
1.5 Capítulo V - um segmento e recortes de um possível segmento extraviado 58

1.5.1 Primeira seqüência: 22 de março (14) 58

1.5.1.1 Principais ações desta seqüência 58

1.5.1.2 Técnicas básicas do padrão narrativo do romance-seriado 59

1.5.2 Conteúdo retirado da versão em livro e não localizado no

$\begin{array}{ll}\text { romance-seriado } & 60\end{array}$

1.5.2.1 Principais ações deste recorte 60

1.5.2.1.1 Uma antítese de Amâncio 60

1.5.2.1.2 A redenção do pai 61

1.5.2.1.3 A decadência da família Coqueiro e a casa de pensão 61

1.5.2.1.4 A morte da mãe e o fechamento da casa de pensão 62

1.5.2.1.5 A segunda mãe - gancho para o próximo segmento 62

1.6 Capítulo VI - um segmento 63

1.6.1 Primeira seqüência: 24 de março (15) 63

1.6.1.1 Principais ações desta seqüência 63

1.6.1.2 Técnicas básicas do padrão narrativo do romance-seriado 64

1.6.2 Conteúdo retirado da versão em livro e não localizado no

$\begin{array}{ll}\text { romance-seriado } & 65\end{array}$

1.6.2.1 Apresentação dos espaços e moradores da casa de pensão 65

$\begin{array}{ll}\text { 1.7 Capítulo VII - oito segmentos } & 67\end{array}$

1.7.1 Primeira seqüência: 27 de março (16) 67

1.7.2 Segunda seqüência: 28 de março (17) 69

1.7.3 Terceira seqüência: 29 de março (18) 70

1.7.4 Quarta seqüência: 31 de março (19) 71

1.7.5 Quinta seqüência: 02 de abril (20) 71 
$\begin{array}{ll}\text { 1.7.7 Sétima seqüência: } 06 \text { de abril (22) } & 74\end{array}$

1.7.8 Oitava seqüência: 07 de abril (23) 75

$\begin{array}{ll}\text { 1.8 Capítulo VIII - dois segmentos } & 75\end{array}$

1.8.1 Conteúdo retirado da versão em livro e não localizado no $\begin{array}{ll}\text { romance-seriado } & 76\end{array}$

1.8.1.1 De casa de Campos à casa de pensão de Coqueiro 76

$\begin{array}{ll}\text { 1.8.2 Primeira seqüência: } 11 \text { de abril (24) } & 78\end{array}$

1.8.2.1 Principais ações desta seqüência 78

1.8.1.2 Técnicas básicas do padrão narrativo do romance-seriado 79

$\begin{array}{ll}\text { 1.8.3 Segunda seqüência: } 12 \text { de abril (25) } & 79\end{array}$

1.8.3.1 Técnicas básicas do padrão narrativo do romance-seriado 80

1.9 Capítulo IX - nove segmentos $\quad 80$

1.9.1 Primeira seqüência: 12 de abril (continuação) (25) 80

1.9.1.1 Técnicas básicas do padrão narrativo do romance-seriado 81

1.9.2 Segunda seqüência: 13 de abril (26) 81

1.9.2.1 Técnicas básicas do padrão narrativo do romance-seriado 82

1.9.3 Terceira seqüência: 17 de abril (27) 82

1.9.3.1 Técnicas básicas do padrão narrativo do romance-seriado 83

1.9.4 Quarta seqüência: 19 de abril (28) 83

1.9.4.1 Técnicas básicas do padrão narrativo do romance-seriado 84

1.9.5 Quinta seqüência: 24 de abril (29) 85

1.9.5.1 Técnicas básicas do padrão narrativo do romance-seriado 86

1.9.6 Sexta seqüência: 25 de abril (30) 86

1.9.6.1 Técnicas básicas do padrão narrativo do romance-seriado 87 
1.9.7 Sétima seqüência: 26 de abril (31)

1.9.7.1 Técnicas básicas do padrão narrativo do romance-seriado

1.9.8 Oitava seqüência: 29 de abril (32)

1.9.8.1 Técnicas básicas do padrão narrativo do romance-seriado

1.9.9 Nona seqüência: 01 de maio (33)

1.9.9.1 Técnicas básicas do padrão narrativo do romance-seriado

1.10 Capítulo X - sete segmentos

1.10.1 Primeira seqüência: 01 de maio (continuação) (33)

1.10.1.2 Técnicas básicas do padrão narrativo do romance-seriado

1.10.2 Segunda seqüência: 04 de maio (34)

1.10.2.1 Técnicas básicas do padrão narrativo do romance-seriado

1.10.3 Terceira seqüência: 09 de maio (35)

1.10.3.1 Técnicas básicas do padrão narrativo do romance-seriado

1.10.4 Quarta seqüência: 09 de maio (36)

1.10.4.1 Técnicas básicas do padrão narrativo do romance-seriado

1.10.5 Quinta seqüência: 11 de maio (37)

100

1.10.5.1 Técnicas básicas do padrão narrativo do romance-seriado 100

1.10.6 Sexta seqüência: 13 de maio (38)

1.10.6.1 Técnicas básicas do padrão narrativo do romance-seriado

1.10.7 Sétima seqüência: 16 de maio (39)

1.10.7.1 Técnicas básicas do padrão narrativo do romance-seriado

1.11 Capítulo XI - um segmento

105

1.11.1 Primeira seqüência: 22 de maio (40)

106

1.11.1 Técnicas básicas do padrão narrativo do romance-seriado 
2.1 Três núcleos narrativos adicionais

2.1.1. Primeiro núcleo: Lúcia

2.1.2. Segundo núcleo: Coqueiro e personagens a ele agregadas

2.1.3 Terceiro núcleo: a fragmentação de Amâncio

2.1.3.1 Último capítulo do romance Casa de Pensão: a reificação de Amâncio 122

2.2 Considerações adicionais

3.3 Ponto de vista do narrador

3.4 Tipologias anunciadas no romance-seriado 
$\begin{array}{ll}4.1 \text { Intertexto } & 173\end{array}$

4.2 A narrativa de Casa de Pensão: a voz e o ponto de vista 174

4.3 Gênero ou a pluralidade discursiva de Casa de Pensão 180

4.4 Jornalismo, literatura e o híbrido 185

4.5 Duas narrativas jornalísticas de um crime $\quad 186$

4.5.1 Jornal do Comércio 188

4.5.2 Gazeta de Notícias 193

4.3.3 Construção do ponto de vista 197

4.6 Nota Antes de principiar e o encontro de dois gêneros 198

4.7 Aventura, intriga e morte: das páginas policiais à Casa de Pensão 204

4.8 Romantismo, Naturalismo e o híbrido 208

$\begin{array}{ll}\text { CONCLUSÃO } & 213\end{array}$

$\begin{array}{ll}\text { REFERENNCIAS } & 218\end{array}$ 


\section{RESUMO}

GARCIA, M, L, G. Aluísio Azevedo: o movimento criativo de Casa de Pensão. Tese (Doutorado). Faculdade de Filosofia, Letras e Ciências Humanas da USP, São Paulo, 2009.

O objetivo deste trabalho é destacar a habilidade com a qual Aluísio Azevedo acompanhou algumas das transformações tecnológicas ocorridas na penúltima década do século XIX. Esta pesquisa analisa o movimento criativo de Casa de Pensão, a partir de textos que compõem o corpus: a primeira edição no formato de romance-seriado, publicada no periódico Folha Nova (1883) e da primeira edição em livro, publicada por Faro \& Lino Editores (1884). As transformações ocorridas no processo criativo foram estudadas por intermédio da metodologia para a análise do padrão narrativo do romance-seriado, sistematizada por Ribeiro (1996; 2000). De modo complementar à apreciação dos aspectos intertextuais, consideramos a influência do contexto do processo criação, de onde emergem vozes relacionadas à Questão Capistrano (1876) e ao hibridismo discursivo imanente à estrutura narrativa do romance Casa de Pensão.

Palavras-chave: padrão narrativo do romance-seriado; movimento criativo; jornalismo e literatura; hibridismo discursivo. 


\begin{abstract}
GARCIA, M, L, G. Aluísio Azevedo: o movimento criativo de Casa de Pensão. [Aluísio Azevedo: the creative movement of the novel Casa de Pensão]. São Paulo (BR); 2009. [PhD Thesis - Faculdade de Filosofia, Letras e Ciências Humanas da Universidade de São Paulo Brazil].

The main aim of this paper is to highlight the ability with which Aluísio Azevedo led some of technological transformations that occurred in the last nineteenth century decade. This research analyses the Casa de Pensão creative movement based on texts that compose the corpus: the first edition in novel-series format published in the journal named Folha Nova (1883), and about the first edition in book format published by Faro \& Lino Editors (1884). The transformations occurred in the creative process were studied through the methodology to analyze the novel-series narrative pattern organized by Ribeiro (1996; 2000). In order to complement the assessment of intertextual aspects, it was considered the influence about the context of the process creation where the voices that were linked to Questão Capistrano (1876) came out and about the discursive hybridism immanent to the narrative structure of Casa de Pensão novel.
\end{abstract}

Keywords: the novel-series narrative pattern; creative movement; journalsm and literature; discursive hybridism. 


\section{INTRODUÇÃO}

Se é arte pertence ao público, pertence à nação, pertence ao mundo [...]

Se é arte, pertence à crítica que a julgará, sem nunca tirar nem pôr do seu merecimento. Forte, ela atravessará os séculos, marcando eternamente na história a época em que veio ao mundo; fraca, morrerá logo ao nascer, desconhecida de todos e esquecida até pelo próprio autor (O COMBATE, 1892, p. 64).

Este estudo tem como objetivo principal situar o romance Casa de Pensão no movimento midiático praticado por Aluísio Azevedo, a partir da análise e interpretação do padrão narrativo presente nas duas primeiras versões do romance. A primeira foi publicada no jornal Folha Nova, em 1883; a segunda foi lançada por Faro \& Lino Editores ${ }^{1}$ um ano depois, isto é, em 1884. Além dos aspectos textuais, consideramos pertinente analisar o contexto de produção e a relação dialógica do texto literário com os aspectos midiático-culturais, a partir dos quais Casa de Pensão teve origem e que podem ser sintetizados na Questão Capistrano (1876).

A reunião desses dois códigos semióticos significava para Aluísio uma ferramenta de divulgação de seu trabalho, um meio de estabelecer diálogos com o leitor, além de contribuir para a venda de seus romances. As preocupações que giravam em torno dos efeitos que a leitura de Casa de Pensão poderia gerar sobre os receptores podem ter impulsionado Aluísio a escrever a nota Antes de principiar (FOLHA NOVA, 05 mar. 1883), com uma síntese do novo romance e o projeto literário almejado com essa publicação.

O fato de Azevedo ter interrompido a publicação dos segmentos antes de seu término pode estar relacionado ao sucesso da história e à mudança de direcionamento do romance. Embora não tenhamos localizado o fascículo de Casa de Pensão, no final de maio de 1883, uma semana dias depois da publicação do último segmento do romance-seriado, o jornal $O$ Mequetrefe informava ao público que um suplemento seria distribuído. Portanto, o romance de Aluísio Azevedo acompanha uma prática comum da época que consistia em vender o romanceseriado de porta em porta como uma forma de apêndice do jornal. Nesse sentido, Sá

\footnotetext{
${ }^{1}$ Por considerarmos a edição de Casa de Pensão lançada pela Ática, em 1977, uma boa edição em termos de fidedignidade textual; e, para uma melhor apreciação, fizemos uma atualização ortográfica das citações feitas na edição de 1884, de forma que, nas citações, limitar-nos-emos apenas a informar a página da qual foi extraído o texto atualizado.
} 
Pinho (O MEQUETREFE, 30 maio 1883, p. 6) informa aos leitores que: "Deve ser distribuído brevemente o primeiro fascículo da 'Casa de Pensão', último romance de Aluísio Azevedo". Na seqüência, o texto destaca que o escritor ainda estava trabalhando no processo de composição, pois o colega do escritor informa que "Aluísio Azevedo tem empregado o máximo esmero na elaboração desta obra, e a 'Casa de Pensão' vai ser talvez o primeiro estudo sério que se tenha feito entre nós, na esfera do romance. Esta qualidade, por um lado e por outro lado, a maneira cômoda como se pretende efetuar a venda do livro, prenunciam um bom êxito.Esse sucesso que saia!" Esta última observação ressalta a certeza de sucesso garantido com a publicação do romance-seriado, como uma forma de conquistar a atenção do público, oferecendo uma amostra de Casa de Pensão.

Consciente da importância dos leitores para a concretização de seu projeto literário, na segunda quinzena de junho de 1883 o jornal O Mequetrefe (K. LOIRO, 10 jun. 1883, p. 7) dá seqüência às notícias sobre o processo de produção do romance Casa de Pensão, deixando o leitor informado que: "Acha-se já distribuído o primeiro fascículo da Casa de Pensão, romance cujo aparecimento fomos dos primeiros a anunciar pela imprensa", com destaque para o privilégio do jornal de acompanhar os desdobramentos do romance. Quando o registro destaca que não seriam feitos comentários: "Para não dar ouvidos para o errôneo paradoxo de que pelo dedo se conhece o gigante, não antecipo nenhum juízo sobre esta obra, baseados em apenas algumas páginas", fica evidente que o fascículo publicou apenas as seqüências divulgadas no jornal Folha Nova, sobretudo porque apenas três semanas separavam a publicação da última seqüência do romance-seriado e do suplemento. Por isso, o autor do comentário revela: "Aguardamos ocasião mais oportuna", o que pode ser depois da publicação do livro. "Por enquanto, para entender os nossos honrados ócios de crítico, limitamo-nos a folheá-la de pena ao léu", ou seja, como um leitor qualquer.

No início de 1884, ano em que seria publicada a versão em livro, o jornal $O$ Mequetrefe expõe um comentário crítico sobre o autor de Casa de Pensão:

Só quem nunca sentiu a mão gelada da realidade entrar-lhe na alma e arrancar lá de dentro, uma a uma, as ilusões, essas douradas partículas do se não compreenderá que $\mathrm{D}$. Quixote ou Philomena moram sem diagnóstico da Policlínica Geral. O Aluísio Azevedo deve perseverar: tem imaginação, estilo, e método de análise. Dessa massa é que fizeram os Zolas e que se fazem os Maupassants (O MEQUETREFE, 20 fev. 1884, p. 6). 
Exatamente um ano depois da publicação do romance-seriado, O Mequetrefe dedica um resumo de todos os romances escritos por Aluísio Azevedo, desde Uma Lágrima de Mulher, seu primeiro trabalho, até Casa de Pensão. Quando se refere a este último, a informação se limita a destacar que esse romance requer "um estudo completo, rigoroso, cruel, da educação brasileira, pede uma aturada análise". Nesse sentido, o jornal apresenta um gancho para um julgamento estético sobre a nova produção de Aluísio: "No nosso próximo número, em artigo escrito por um dos mais competentes críticos brasileiros, faremos à Casa de Pensão as honras e que a julgamos com pleno direito" (O MEQUETREFE, 30 maio 1884, p. 5).

Embora não saibamos quem era o crítico mencionado acima, depois que ele se recusou a escrever a apreciação crítica sobre Casa de Pensão, o jornal explica que o gaúcho Júlio de Castilhos enviaria um artigo para suprir essa falha:

\footnotetext{
Em um dos passados números do Mequetrefe nos comprometemos a publicar um artigo crítico sobre o último romance de Aluísio Azevedo, mas fomos flauteados pelo cavalheiro a quem havíamos cometido esta tarefa. Entretanto, cai-nos do céu - queremos dizer de Porto Alegre um número da "Federação" (órgão republicano habitualmente dirigido pelo Sr. Júlio de Castilhos), que nos deparou precisamente o que desejamos, isto é - um bom artigo sobre o assunto (O MEQUETREFE, 30 jun. 1884, p. 6).
}

Em meados de 1884, Casa de Pensão apareceu em livro, com o acréscimo dos dez capítulos que não foram divulgados na primeira variante e a reformulação em alguns dos trechos dos primeiros doze capítulos, publicados no jornal Folha Nova. Logo após a aparição da segunda versão do romance, a Gazeta Literária publicou uma apreciação sobre a estratégia escolhida por Aluísio, na qual Urbano Duarte revelou as etapas de divulgação do romance, por considerar o percurso criativo do romance: "Casa de Pensão começou a ser publicada na 'Folha Nova', depois passou a ser editada de princípio pelo senhor Filinto da Silva, saindo em fascículos, com estampas devidas ao lápis do senhor Aurélio de Figueiredo". Tanto na primeira, em romance-seriado, como na segunda, à qual não tivemos acesso, ficou "o romance interrompido, e agora o autor nos dá o livro em edição completa, que se pode portanto classificar como terceiro"2. Destacamos que também foram feitas pelo pintor Aurélio Figueiredo as estampas litrografadas, localizadas na 
primeira edição de Casa de Pensão (popular), editada por Faro \& Lino - RJ, em 1884.

A citação acima é apenas um exemplo de como os leitores reagiram ao processo de produção do romance Casa de Pensão e o efeito que o corte causou sobre alguns leitores, depois que Aluísio suspendeu a publicação em maio de 1883, deixando os leitores ansiosos para conhecer o restante da história.

Como os testemunhos do processo de produção reconstroem a atmosfera que acompanhou a escrita de Casa de Pensão, é possível entender um pouco do movimento que fez parte do percurso criativo utilizado por Aluísio Azevedo no período que parte de 06 de março a 22 de maio de 1883, com o romance-seriado, abrangendo, assim, XII capítulos dos XXII que compôs o livro, ou seja, no segundo semestre de 1884.

Embora nossa pesquisa tenha selecionado apenas as duas primeiras publicações já citadas, destacamos que o romance Casa de Pensão ultrapassou os limites do Rio de Janeiro, quando foi publicado no jornal $A$ Bagagem, em Minas Gerais $^{3}$ (1884-1885), a partir do texto da primeira versão em livro.

Depois de apresentarmos testemunhos do processo criativo de Casa de Pensão (1883-1884), destacamos um panorama da crítica posterior, com a finalidade de situar o ponto de vista seguido neste estudo.

De modo quase que totalitário, a crítica de Aluísio Azevedo divide suas obras em duas partes: a dos romances-seriados, julgada por seu caráter mercadológico ou de entretenimento (que tem início com a primeira produção Uma Lágrima de Mulher, e estende-se a: Girândola de amores, Condessa Vésper, Filomena Borges, A Mortalha de Alzira e Mattos, Malta, Mata?) e a outra, a dos romances reconhecidos pela crítica pela qualidade estética (O Mulato, Casa de Pensão, O Cortiço). Além das romances citados, acrescentamos O homem, O Coruja, Livro de Uma Sogra, que parecem não possuírem um lugar definido pela crítica. Embora o romance Casa de Pensão seja classificado no segundo conjunto de obras, a crítica de Aluísio não considera o movimento de criação do discurso que parte da publicação destinada ao jornal Folha Nova (1883) e recebe mais dez capítulos para ocupar o formato de livro (1884), sem, contudo, excluir do conteúdo narrativo, algumas das técnicas características do romance-seriado, o que estabelece um elo entre as duas

3 A Bagagem. Aluísio Azevedo. Casa de Pensão. Ouro Preto, 04 dez. 1884 - 08 out. 1885. 
variantes. Nesse sentido, destacamos que Aluísio, como escritor, no romanceseriado explora as categorias de um modo complexo e no livro preserva técnicas características da primeira versão elaborada para o jornal.

Como nossa intenção é apresentar o caráter valorativo das etapas que envolvem o movimento criativo de Casa de Pensão, não daremos destaque para julgamentos que dividem a literatura de Aluísio, ora exaltando suas obras, ora reduzindo-as, dependendo do gênero ao qual foram publicadas. Desse modo, reproduziremos apenas o texto escrito por Alfredo Bosi por traduzir o preconceito tido por grande parte da crítica sobre os romances-seriados:

Em Aluísio Azevedo a influência de Zola e Eça é palpável; e, quando não se sente, é mau sinal: o romancista virou produtor de folhetins. Aliás, trata-se de um caso raro e precoce de profissionalização literária: Aluísio Azevedo disse Valentim Magalhães - é no Brasil talvez o único escritor que ganha o pão exclusivamente à custa de sua pena, mas note-se que apenas ganha o pão: as letras no Brasil ainda não dão para a manteiga. Essa luta com a pena pelo pão certamente explica o desnível entre seus romances sérios $(0$ Mulato, Casa de Pensão, O Cortiço) e os pastelões melodramáticos de 'pura inspiração industrial", no dizer de José Veríssimo (Condessa Vésper, Girândola de Amores, a Mortalha de Alzira...). E talvez à mesma causa se possa atribuir o estranho abandono das letras que se lhe nota a partir dos quarenta anos, quando entra para a carreira diplomática e se elege membro da Academia recém-fundada (BOSI, 1994. p. 210).

Diferente da avaliação pejorativa acerca dos romances publicados em jornal, o ponto de vista apresentado neste estudo considera que todas as etapas do processo criativo são essenciais para a caracterização da habilidade de Aluísio Azevedo, visualizada na atribuição de plasticidade ao discurso de Casa de Pensão, como estratégia para atender às expectativas dos leitores e da crítica, às transformações tecnológicas e ao ritmo de interação dos indivíduos, o que também encontra fundamento do movimento criativo que encaminha o leitor para o romance moderno. Nesse sentido, destacamos a valorização da mistura de gêneros e linguagens, que em Jean-Yves Mérian (1988, p. 417) encontra esta definição substancial de que: "os romances-folhetins não se opunham de modo absoluto aos romances naturalistas, mas, segundo Aluísio, deviam contribuir ao progressivo sucesso destes. A relação entre esses dois tipos de romances era de ordem dialética, sendo o objetivo final a "aclimatação" do Naturalismo no Brasil".

Apesar do movimento favorável à fixação do romance moderno no viés do desenvolvimento tecnológico, não se pode deixar de citar as considerações feitas 
por Martín-Barbero (2001, p. 323-324) de que "o que ativa essa memória não é da ordem dos conteúdos, nem sequer dos códigos, é da ordem das matrizes culturais", por isso, cada variante de Casa de Pensão pode ser entendida de acordo com o público que a lê.

Ao focalizarmos Casa de Pensão, encontramos em Araripe Júnior apreciações críticas que lhe conferem um lugar de destaque dentre os críticos de renome que assistiram ao aparecimento do romance, sobretudo pelas contribuições realizadas com a percepção de uma psicologia social objetiva na caracterização dos personagens, guiados pelos impulsos e formas advindas do meio que serve de cenário, tendo em vista que:

Ali [Casa de Pensão] não há reses, nem demonstrações. Os personagens valem uns pelos outros; encontram-se e relacionam-se naturalmente, impelidos pela fatalidade do meio; e não se perfilam, não se curvam, como nos romances antigos, à maneira de serventes humildes, aplainando o caminho do herói, desempenhando uma função no enredo, guiando docilmente a ação a um fim preconcebido, embora com sacrifício das linhas principais dos respectivos caracteres. [...] O que seu espírito [de Aluísio Azevedo] abrange e apanha com mais facilidade é a ligação dos caracteres entre si. Vide, por exemplo, com que rara felicidade ele, depois de apresentar o estudante Amâncio de Vasconcelos no Rio de Janeiro, soube agrupar em torno deste personagem os objetos e as pessoas que com mais força deviam reagir sobre o seu temperamento. Daí uma aglutinação nas cenas que se sucedem, que dão aos fatos descritos um encanto indeclinável.

A vida é contagiosa. O mundo é formado por uma série de cárceres, aonde nos é impossível escapar à influência que os detentos, de ordinário, exercem uns sobre os outros [...] (APARIPE JR apud BOSI, 1978, p. 139).

Tanto o cenário captado pela lente do escritor, quanto os personagens, oriundos de seres tipificados, revelam o ponto de vista de Aluísio Azevedo e o mundo criado por intermédio da ficção. Desse modo, Casa de Pensão reúne caracteres associados ao cotidiano assistido pelo autor, pois:

Os escritores realistas, grosso modo, podem ser vistos como alguém que usava uma câmera, como dissemos; todavia, quando nos carregam com eles da praça para a rua, da rua para a casa e daí para os cômodos específicos onde vivem as personagens, fazem isso com a quantidade e a qualidade de sugestão verbal que, por meio da leitura, traduzimos em imagens mentais. Os cômodos, os objetos, as personagens e o próprio movimento são parte de uma espécie de "olho da mente" que pertence ao mesmo tempo ao autor e ao leitor. Entretanto, uma câmera móvel executando a mesma movimentação, o faz com uma rapidez que requer a mesma rapidez do olhar, numa célere e abrupta associação de imagens, que pouco solicita da mente. Tudo está pronto para ser visto, e não 
imaginado. Assim, tem-se a absolutização da imediatez da imagem, que opera de maneira totalmente diferente da imediatez da palavra (PELLEGRINI, 2003, p. 25).

Para corroborar com as apreciações de Araripe e ressaltar as habilidades artísticas de Aluísio Azevedo, destacamos a sucinta e esclarecedora definição realizada por Adonias filho de que: "Em Casa de Pensão, embora limitando o espaço social que ausculta, movimenta um dos aspectos mais típicos do urbanismo carioca"4.

Sobre Casa de Pensão, Bosi escreve:

Em Casa de Pensão, a vida airada do estudante que vem do Norte para o Rio, o ambiente pegajoso da pensãozinha onde se instala, enfim o rumor dos jornais e da boêmia em volta do caso escandaloso em que se envolve, formam coro, estruturalmente superior ao desenho, flácido, do protagonista, cujas fraquezas são atribuídas desde as primeiras páginas à herança de sangue (BOSI, 1994, p.157).

Beviláqua (1988) afirma que sobre o fundo histórico do romance Casa de Pensão levantado por Aluísio, o autor o executou de tal forma que o leitor chega a supor que não está folheando um romance, mas a narração de um fato real escrita com elegância e muita habilidade:

\begin{abstract}
Os caracteres são todos verdadeiros, se expondo naturalmente, sem contradição e sem surpresas, as cenas são copiadas do natural, revivem os cantos obscuros da sociedade fluminense, reproduzem a vida íntima que se retrai da qualidade solar das ruas e se desabotoa na tipidez do gineceu e das recamaras fouxeladas. (...) Aluísio sabe ver com olhos de observador perspicaz, e descreve as observações colhidas como verdadeiro artista (BEVILAQUA, 1888, p.178-179).
\end{abstract}

Segundo Moisés, Casa de Pensão é elaborada "a maneira dos mestres europeus do realismo, Aluísio muda a cena do romance a fim de experimentar a recorrência das leis hereditárias e ambientais sobre indivíduos afastados no espaço e na classe social" (MOISÉS, 1984, p. 342).

Aderaldo Castelo (1999, p. 395), a seu turno, concorda com Raimundo Menezes (1958) e Moisés (1884), ao ressaltar que Casa de Pensão "[...] representa a vida pequeno burguesa, universo no qual se situam os protagonistas de um crime passional a partir de fato verídico”, acrescentando que Aluísio “... procede conforme 
ensinamentos de Zola sobre o romance - faça reportagem" (CASTELO, 1999, p. 395-396).

De modo complementar, mas igualmente importante, não podemos deixar de citar os personagens caricatos, construídos na atmosfera criativa do romance. Nesse sentido, constata-se que o processo de produção da obra Casa de Pensão foi lento e surpreendente. O procedimento do escritor, adotado para a composição de seu conjunto de textos, e o depoimento de seus colegas escritores indicam que o percurso da obra se iniciou a partir do momento em que Aluísio desempenhou o papel de leitor, assimilando informações sobre a Questão Capistrano. Posteriormente, pressupomos que tenha visitado casas de pensão da cidade para observar cenas de seu cotidiano carioca e os personagens caricatos no movimento criativo.

A importância da linguagem visual e o movimento atribuído aos personagens têm relação direta com a plasticidade com a qual se moldou o discurso de Casa de Pensão, como uma reunião das habilidades do escritor. Poucos dias depois da morte de Aluísio Azevedo, o conterrâneo e colega de moradia Coelho Neto destaca aspectos fundamentais dos procedimentos utilizados por seu mestre:

Refletir sobre a singularidade do estilo de Aluísio Azevedo, perante seu talento por uma diversidade de modalidades artísticas, por isso, para escrever Casa de Pensão usou por palco sua mesa onde se baralhavam figurinhas, desenhadas pelo próprio escritor, que eram os tipos dos seus personagens (O IMPARCIAL, 25 jan. 1913, p. 7).

Na seqüência, Neto descreve o mundo fantástico criado por Aluísio Azevedo, por meio do qual o autor podia ter os personagens como marionetes, "ante os olhos, jogando com eles permanentemente, como que se cercava do mundo psicótico, que ele deveria agitar com a vara encantadora de sua pena".

Em Menezes (1958, p. 84-87), consta-se que Aluísio "devora a jato" O Crime do Padre Amaro e empenha-se para seguir sua trilha: "o material humano está à sua disposição e basta colhê-lo, nas ruas acidentadas, nas igrejas transbordantes de beatas, nos sobrados, onde mexericos dominam... Assim, os personagens - nada mais fácil - vivem por ali em carne e osso [...]". Em complemento, o biógrafo destaca que "[...] para melhor guardar os tipos, apanhados no ramerrão da vida cotidiana, como Balzac e Dostoiévsky, traça-Ihes a caricatura em bonecos (aquarela, quando 
bons, a lápis, quando maus) que se acotovelam sobre a desarrumada mesa de trabalho. Servir-Ihe-ão de valioso roteiro [...]".

Com efeito, colocando-se em contato com o meio investigado, o autor ouvia, observava, anotava diálogos e traçava tipos e, a partir de então, Aluísio atuava na condição de criador, elaborava os primeiros esquemas do romance em germe para, em seguida, desenhar seus personagens em cartolinas, dispondo-os sobre a mesa na qual desenvolvia o seu trabalho:

desenha em cartolina os bonecos dos dois principais heróis: o estudante Amâncio de Vasconcelos, moço de vinte anos, tipo do Norte, franzino, amorenado [...] e a jovem Amélia Coqueiro, de cabelo denso e castanho, bem feita de quadris e de ombros, cintura em volta enérgica [...] (MENEZES, 1958, p. 150-151).

Do mesmo modo, a propósito do método utilizado por Aluísio para a produção de suas obras, dentre as quais destacamos Casa de Pensão, enfatizamos o ponto de vista de Araripe Júnior, segundo o qual: "Esta precedência da caricatura sobre o romance tem, para mim, uma importância particular, porque explica desde logo o caráter de seu talento e põe a descoberto todo o eixo do seu espírito". Desse modo, o crítico acrescenta que a tendência direta para o concreto, localizada nessa representação, "tem no mais alto grau o espírito de observação ligado ao mais cabal sentimento do real e das suas máquinas de expressão" (ARARIPE JR apud BOSI, 1978, p. 35).

Neste estudo, a reunião dos documentos que compõem o processo investigativo - localizados na Biblioteca Nacional - RJ - é fundamental para criar a atmosfera criativa do romance Casa de Pensão. O diálogo intertextual leva-nos a acreditar na capacidade que Aluísio Azevedo possuía para entender as mudanças de perceptiva, advindas dos efeitos das tecnologias sobre os indivíduos. Essa hipótese parte do pressuposto de que, em meio a tantas transformações provocadas pelo aparecimento de um novo meio: "O artista pode corrigir as relações entre os sentidos antes que o golpe da nova tecnologia adormeça os procedimentos conscientes" (MCLUHAN, 1964, p. 86).

Nesse sentido, a leitura do contexto de produção de Casa de Pensão é balizada pelo apontamento feito por McLuhan, de que os meios de comunicação 
estão se misturando, quebrando suas fronteiras rígidas, utilizamos a definição de meios híbridos para abranger os canais de publicação, bem como o contexto produtivo das duas primeiras versões de Casa de Pensão, que resultam em um gênero híbrido.

Como texto basilar para o estudo do movimento criativo de Casa de Pensão, no processo que esmiúça a escrita do romance, adotamos categorias de análise capazes de contemplar, metodologicamente, as peculiaridades do objeto de pesquisa do qual nos ocupamos, em José Alcides Ribeiro (1996, p. 44-46; 2000, p. 164-179) obtivemos "um painel das técnicas estruturadoras do perfil padronizado da convenção narrativa folhetinesca", o qual foi elaborado pelo autor a partir da "recepção crítica do romance folhetim francês". Portanto, esse conjunto de técnicas norteou a análise da história de Casa de Pensão, na versão do romance-seriado, além de oferecer subsídios para a elaboração de hipóteses sobre a construção do discurso híbrido do livro, resultante do método de criação da história.

Como construímos tipologias para caracterizar as técnicas composicionais, a fim de entender como ocorreu o processo de alteração das variantes de Casa de Pensão, realizamos uma divisão do campo do estudo. Por essas razões, adotamos as categorias propostas por Todorov, que classifica os problemas da narrativa em três categorias: a) Tempo (que exprime a relação entre o tempo da história e do discurso); b) aspecto (ou a maneira como a história é percebida pelo narrador); c) modo, ou seja, o tipo de discurso utilizado pelo narrador.

Essas três categorias são reformuladas por Genette (1995, p. 27-30) como visão (aspecto), que se remete a questões de ponto de vista narrador; registro (modo), abrangendo os problemas de representação e narração (distância); e voz que designa, ao mesmo tempo, as relações entre narração e narrativa e entre narração e história. Para as finalidades propostas neste estudo, privilegiaremos as categorias voz e ponto de vista.

Paul Ricoeur (1990, p. 165-66) destaca que a noção da experiência fictícia do tempo não pode prescindir dos conceitos de ponto de vista e de voz narrativa, ou seja, o ponto de vista recai sobre a esfera da experiência à qual concerne a personagem e a voz narrativa e é a que se dirige ao leitor, apresentando-lhe o "mundo narrado", que, em Casa de Pensão, é realizado na nota Antes de principiar. Nessa perspectiva, aplicamos os conceitos apresentados por Ricoeur que liga as noções de ponto de vista e de voz narrativa às categorias de narrador e de 
personagem. O mundo narrado em Casa de Pensão é o mundo das personagens referenciadas na construção dos tipos que compõem o romance e é contado por um narrador guiado pelo autor, escritor-jornalista. Portanto, a enunciação é o discurso do narrador, que por vezes é autor-narrador, enquanto o enunciado é o discurso da personagem, com vozes que se remetem ao cotidiano dos leitores contemporâneos ao lançamento das duas primeiras versões da história.

Van Dijk (1990) propõe um procedimento capaz de abranger a análise de diferentes níveis do discurso, em diferentes sistemas semióticos, relacionados ao jornalismo e à literatura, assim como os demais elementos relacionados ao contexto produtivo. Nesse sentido, van Dijk (1990, p. 45) enfatiza que as dimensões textuais dão conta das estruturas do discurso em diferentes níveis de descrição e as relacionam com diferentes propriedades do contexto, como processos cognitivos e as representações pronominais, que podem ser diferentes para a análise da linguagem elaborada para a versão em jornal e em livro.

Essa intersecção de campos enfatiza o valor da linguagem híbrida, não apenas para caracterizar a poética de Aluísio Azevedo e a habilidade de o autor acompanhar as transformações tecnológicas, mas também para situar Casa de Pensão como representação de um fenômeno sociocultural. Dito isso, retomamos o objetivo de situar o romance Casa de Pensão no movimento midiático, com a apresentação do movimento criativo da diegese e habilidade adquirida por Aluísio em sua profissão de escritor.

Mais do que compreender a necessidade de dominar a técnica da escrita industrial, Aluísio também procurava entender e escrever de acordo com suas concepções artísticas, em direção ao romance moderno. Isso se explica porque, segundo Albérès (1962, p. 38), a grande transformação ocorrida com o romance do século XIX, como "document romance", está ligada às suas condições de publicação. Para o autor, não é possível entender o romance realista sem primeiramente verificar seu aspecto de retrato do cotidiano. Portanto, o maior romance desse século é o romance-seriado, com o estudo da sociedade, em seus aspectos pitorescos.

Levando em consideração os procedimentos apresentados, o primeiro capítulo apresenta uma análise minuciosa do romance-seriado, a partir do conceito basilar sistematizado por José Alcides Ribeiro (1996) e presente na obra Imprensa e Fiç̧ão no Século XIX: Edgard Allan Poe e a Narrativa de Arthur Gordon Pym. Além 
de propor uma metodologia de análise, Ribeiro também analisa um texto escrito por Poe, publicado, parcialmente, no formato de romance-seriado e, posteriormente, duplicado integralmente em livro, o que representa grande semelhança ao processo de publicação do romance aqui cotejado. Portanto, esse conjunto de técnicas norteia a análise da história de Casa de Pensão, na versão do romance-seriado, além de oferecer subsídios para a elaboração de hipóteses sobre a construção do discurso híbrido do livro, resultante do método de criação da história, o que é apresentado no segundo capítulo desta pesquisa.

O terceiro capítulo apresenta exemplos representativos das alterações ocorridas no conteúdo do romance-seriado quando recebe o formato de livro, ou seja, são considerados apenas os principais textos comuns às duas vertentes. Nas duas situações comunicativas, a apresentação da tipologia textual utilizada na composição do enredo envolve códigos fundamentais à hermenêutica do texto e à definição de semas que delineiam os personagens e os cenários onde ocorre o desenvolvimento da narrativa. Encontramos em Genette (1995) e Ricoeur (1990) noções substanciais para detectar a visão narrativa em Casa de Pensão como um caminho para desvendar em que medida o ponto de vista dos personagens e do narrador orienta a perspectiva narrativa nas duas versões cotejadas. A partir disso, podemos entender a habilidade do escritor de atribuir plasticidade à linguagem literária, em função dos meios aos quais ela se vincula, por intermédio da publicação, concretizando o projeto daquele que despendeu esforços em dois momentos criativos.

No quarto e último capítulo, são apresentados elementos intratextuais e extratextuais, no intuito de caracterizar o diálogo do texto e o contexto na construção do gênero de Casa de Pensão (1883-1884), em função da plurissignificação discursiva. Esta etapa do estudo apresenta uma leitura da relação do tema do romance com a Questão Capistrano (1876), a partir de notícias divulgadas pelo Jornal do Comércio e pela Gazeta de Notícias. A reunião dos diversos códigos semióticos localizados no romance, ligados à situação comunicativa, contribui para a construção de um microcosmo da sociedade carioca que abrange as décadas de 1870 e 1880. Como resultado, podemos entender em que medida as notícias podem ser cristalizadas no universo textual do romance, pelo código sociocultural empregado na ficção. 


\section{TÉCNICAS DE ROMANCE-SERIADO}

Desde pequeno, Aluísio Azevedo via o mundo com o olhar de um artista. Pintava o cenário em que ele e seus irmãos representavam as peças criadas pelo irmão Artur Azevedo e amava o Maranhão, assim como admirava os grandes poetas conterrâneos. Se os projetos de estudar pintura em Roma não foram concretizados, Aluísio viu outras possibilidades viáveis para dedicar-se à pintura do mundo, o que, muitas vezes, fazia de forma caricata para ressaltar os defeitos que via e como os via.

Foi também ao lado de membros de sua família que Aluísio dedicou-se à atividade jornalística. Seguindo os passos de Artur, ele decidiu fixar-se na Corte e ali dar continuidade às modalidades artísticas já adquiridas. Foi assim que Aluísio começou a trabalhar como caricaturista em jornais como O Fígaro, O Mequetrefe, Zig-Zag e A Semana Ilustrada. Depois de uma passagem pelo Maranhão, seu retorno ao Rio de Janeiro deu início a uma carreira exemplar de folhetinista, como um hábil escritor de romances-seriados, como grandes crônicas do cotidiano, reveladas de modo caricato.

Sobre o gênero do romance-seriado, as produções que antecederam Casa de Pensão, os temas e a linguagem naturalista, o crítico Araripe Jr. (apud BOSI, 1978, p. 135) ressalta que: "Depois da brilhante estréia d'O Mulato (1881-1882), o autor andou a satisfazer a avidez dos leitores de rodapé, escrevendo as Memórias de um condenado e Os Mistérios da Tijuca, vazando-os, embora com muitas restrições, nos moldes de Xavier de Montépin e de Panson du Terrail".

O romance-seriado Memórias de um Condenado - lançado em 1882, um ano antes da primeira variante de Casa de Pensão - estimulou um leitor em especial a escrever uma carta a Aluísio, como uma espécie de crítica a algumas particularidades do romance-seriado.

Em resposta, Aluísio compôs a epístola "A Giovani (particular)", revelando que, embora não tivesse o hábito de responder às cartas dos leitores, o faria nesse caso, demonstrando certa intimidade com aquele que the escreve: "Querido desconhecido. - A tua carta é a primeira carta anônima que respondo, das

\footnotetext{
${ }^{5}$ Obras completas de Aluísio Azevedo. O Touro Negro. São Paulo: Martins, 1961. p. 51-54 (grifos nossos).
} 
muitíssimas que até hoje tenho recebido. E a razão disso está simplesmente no modo asseado por que me falas", o que pode não se tratar de um leitor qualquer, mas de um crítico. Nossa constatação parte do pressuposto de que somente um conhecedor de literatura teria a atitude de fazer apontamentos em uma obra que já havia obtido reconhecimento no meio literário. Além disso, a aparente confiança conquistada de Aluísio é expressa quando o escritor se dirige ao leitor anônimo nestes termos: "Ofereceste-me obsequiosamente para anotar o meu romance 0 Mulato e eu aceito e agradeço o oferecimento, sentindo apenas não possuir um exemplar para pô-lo à tua disposição".

Se considerarmos a literatura como um processo que encontra no romanceseriado uma vertente plástica, tanto pelo formato quanto pela possibilidade de mudança de perspectiva durante a publicação dos segmentos, a crítica poderia contribuir para o reconhecimento das obras. Nessa perspectiva, Aluísio acrescenta: “- Estou reconhecido pelas palavras lisonjeiras que me dedicas e mais ainda pelo interesse que mostras pelas minhas produções".

Sobre o romance-seriado Memórias de um Condenado, publicado um ano antes do primeiro surgimento de Casa de Pensão, podemos dizer que a proximidade temporal entre a publicação dos dois romances revela particularidades dos procedimentos utilizados por Aluísio na produção de romances-seriados, ao mesmo tempo em que desvenda o significado desse gênero no processo criativo de suas obras, conforme registrado na mesma carta:

Quanto ao que dizes a respeito das Memórias do condenado ${ }^{6}$, pesa-me confessar-te uma coisa: - Tu tomaste muito a sério essa obra.

Que não nos ouçam os leitores do rodapé, mas impõe-me a franqueza declarar-te que as Memórias, enquanto não aparecerem em volume, não merecerão desvelos de ninguém.

Romance de au jour le jour, escrito para acudir às exigências de uma folha diária, está, como facilmente se pode julgar, eivado de erros e descuidos, que só na revisão para o volume poderão desaparecer.

Além disso, os erros tipográficos são tantos e tão constantes, que constituem uma verdadeira calamidade. Ainda no último folhetim, eu escrevi - belos brilhantes, e os tipógrafos disseram - velhos brilhantes; em outro lugar falo de pedras limpas, e eles emendaram para límpidas. Isto sem querer citar as repetidas transposições que alteram completamente o sentido do que está escrito; as palavras incompletas, os saltos e mil outros inimigos do estilo e da boa lógica gramatical.

\footnotetext{
${ }^{6}$ Romance-seriado, publicado na Gazetinha - Rio de Janeiro de $1^{\circ}$ de janeiro a 7 de junho de 1882.
} 
O conteúdo a seguir expõe como Aluísio diferenciava a linguagem ligada à produção folhetinesca daquela registrada em livro e a preocupação com o efeito causado pela linguagem naturalista. Em resposta a alguns questionamentos feitos por Giovani ${ }^{7}$, leitor do romance-seriado Memórias do Condenado - Aluísio publica o seguinte texto:

Mas vejamos as tuas três primeiras emendas:

$\left.1 .^{\circ}\right)$ Queima como pus.

Se bem que isto não seja uma frase completamente verdadeira, tem todavia algum fundo de verdade. Há certo pus venenoso, que possui propriedades de cáustico, e queima a epiderme. Podes facilmente verificar esse fato nas feridas venéreas. Contudo não discuto a frase, porque não reconheço nela valor algum.

$\left.2 .^{\circ}\right) \mathrm{O}$ abuso das frases - Que diabo! com os diabos! etc., etc.

Não me pareces nisso muito razoável, mas enfim pode ser que tenhas razão.

$\left.3^{\circ}{ }^{\circ}\right)$ Pedes a supressão de certo adjetivo, porque ele pode lembrar desgostos a uma senhora, que ambos nós respeitamos.

Quanto a isso, só me resta declarar-te uma coisa: - Para poupar um desgosto a uma senhora de minha estima, eu seria capaz de sacrificar um dedo, quanto mais um adjetivo [destaques do autor].

Sobre a resposta dada por Aluísio, destacamos o primeiro item citado acima, por intermédio do qual o escritor explica que a utilização do vocábulo "pus" está relacionada à linguagem naturalista que emprega termos científicos para demonstrar particularidades de algumas das cenas retratadas nos romances; no segundo item, o escritor responde ironicamente à crítica quanto à utilização excessiva da expressão "com os diabos!", sobretudo porque essa é uma estrutura que aparece de modo recorrente nas produções de Aluísio, tanto nos romances-seriados quanto nos livros; e é com ironia que o escritor também responde ao último item.

Ao valorizar as contribuições que serviam para o aprimoramento artístico, Aluísio finaliza a epístola de modo objetivo, com a seguinte consideração: "Creio que te fiz a vontade; espero por conseguinte que sejas mais severo nas tuas notas. Vê se dizes alguma cousa sobre a concepção artística de meus trabalhos".

Se, por um lado, Aluísio preocupava-se em seguir a nova estética RealNaturalista, por outro lado, tinha consciência de que os leitores ainda estavam acostumados a ler romances românticos. $O$ resultado desse impasse foi a adoção de um gênero híbrido, que tanto agradaria os leitores quanto a crítica. Em Os Mistérios da Tijuca (FOLHA NOVA, 1882-1883) - publicado em folhetim até 18 de fevereiro de

\footnotetext{
${ }^{7}$ Aluísio Azevedo. O Touro Negro, 1961, p. 51-54 (grifos nossos).
} 
1883, que seria sucedido por Casa de Pensão no mesmo jornal, a partir de 05 de março do mesmo ano -, Aluísio enfatiza que pretende introduzir o leitor ao romance moderno, a partir de doses de Romantismo que "vão gradativamente diminuindo enquanto que as do Naturalismo irão se desenvolvendo; até que, um belo dia, sem que o leitor se sinta, esteja completamente habituado ao romance de pura observação e estudo de caracteres". Ao empregarmos esse procedimento ao romance Casa de Pensão, o código híbrido pode nos revelar quais eram as doses de Romantismo e de Naturalismo dadas aos diferentes públicos. Sobre esse aspecto, Brayner (1973), que, de certo modo, responde, indiretamente, aos apontamentos feitos por Giovani (anônimo), enfatiza que:

\footnotetext{
O que agrada aos críticos favoráveis à técnica naturalista é a possibilidade de um julgamento dos costumes sociais, muito dentro da linhagem eciana. Entretanto, o aspecto descritivo e desvendador é julgado com severidade, pois pode macular a inocência de leitores despreparados ou mocinhas ávidas de sensações proibidas (BRAYNER, 1973, p. 26).
}

Conhecido em seu meio pela polêmica levantada em seus romances, entre 1882-1883, Aluísio Azevedo empenhava esforços para acostumar o leitor à leitura de romances naturalistas. O crítico Araripe acompanhou esse processo, por isso pergunta:

\footnotetext{
Por mais de uma vez, se lhe aprazia assanhar essa fera chamada - público, atirando-lhe pedaços de carne crua e ensangüentada, como costumam fazer os domadores, para mostrar mais realçadas as suas qualidades dominadoras. A resposta a estas e outras injunções foi o aparecimento de Casa de Pensão (ARARIPE JÚNIOR apud BOSI, 1978, p. 135).
}

Mas o que seria essa carne crua e ensangüentada? Será que o crítico estava fazendo apenas uma referência à linguagem naturalista? Não, mais do que isso, a carne crua em Casa de Pensão pode estar relacionada às informações que referenciam um drama, quando o escritor retoma um tema que se encontra vivo na memória de muitos dos leitores, pois apenas sete anos separavam o trágico assassinato de Capistrano da Cunha (1876) da ficção (1883). Sobre o processo criativo desse romance, Bosi acrescenta que:

Em Casa de Pensão, a vida airada do estudante que vem do Norte para o Rio, o ambiente pegajoso da pensãozinha onde se instala, enfim o rumor dos jornais e da boêmia em volta do caso escandaloso em que se envolve, 
formam o coro, estruturalmente superior ao desenho flácido, do protagonista, cujas franquezas são atribuídas desde as primeiras páginas à herança do sangue (BOSI, 1994, p. 190).

Para Aluísio, o Naturalismo e a literatura não representavam apenas uma linguagem e uma estética, mas uma atitude diante da sociedade e uma maneira de exercer, em sua função, um combate ideológico. Nesse sentido, o sucesso da ficção significava um sinal de respeito às idéias que nele estavam vinculadas e a garantia de venda de sua produção artística. Suspender a publicação em folhetim e dedicarse à edição da versão em livro significava que os onze capítulos da primeira versão haviam garantido que o livro também obteria sucesso e venda. Nesse aspecto, o processo de criação de Casa de Pensão em folhetim é desenvolvido para visibilidade social.

No contexto específico das trocas simbólicas desenvolvidas a partir de uma dialética reiterativa entre o romance Casa de Pensão e a Questão Capistrano, os tipos de sociedade representados nas variantes aparecem sujeitos da experiência do espaço, ou seja, sua culminância ocorre de acordo com um corpo social, historicamente determinado, que a realiza. Desde o momento em que os leitores se propõem a desvendar o que há de imaginário em Casa de Pensão, a sociologia da arte se autentica pelo caráter de representação de conhecimento ligado ao contexto carioca do século XIX. Nessa perspectiva, Francastel (1968, p. 1728) ressalta que: “jamais o signo plástico é o duplo ou o equivalente do real, ele é um relais. Ele não manifesta um fato ou uma idéia [...], mas uma causalidade. É o testemunho de uma conduta, não o reflexo de uma essência".

A estrutura artística de Casa de Pensão pode ser vista pela via dupla, tanto pela linguagem intertextual, que influencia as escolhas lingüísticas e a construção de sentido do texto, da mesma forma que por influenciar os leitores e uma sociedade pelo ponto de vista expresso nas entrelinhas do discurso literário. Quando Aluísio opta por inserir, gradativamente, o Naturalismo, respeitando o hábito que o público ainda cultivava pelos romances românticos, expressa a intenção de familiarizar o leitor com o novo gênero em plena atividade na Europa graças à produção artística de Émile Zola, que influencia a literatura brasileira, principalmente as produções de Aluísio Azevedo. A preocupação com a elaboração de uma obra literária representa um sistema dialógico integrado pelo leitor e escritor. Sobre o sistema de comunicação, o estruturalista Lotman destaca que: 
A escolha pelo escritor de um gênero, de um estilo ou de uma tendência artística determinados é também a escolha da linguagem na qual ele pensa falar ao leitor [...] A transcodificação de uma linguagem noutra, extremamente produtiva na maioria dos casos e que surge em ligação com os problemas interdisciplinares, descobre num único objeto, tal como parecia antes, os objetos de duas ciências ou leva à elaboração de um novo domínio do conhecimento e de uma nova metalinguagem que the é própria (LOTMAN, 1978, p. 50-51).

A leitura intratextual do romance Casa de Pensão pode identificar códigos ligados ao gênero da publicação. No entanto, apenas os leitores contemporâneos à publicação do romance-seriado ou aqueles que têm acesso ao conjunto de quarenta seqüências e das notícias da Questão Capistrano poderão identificar facilmente os códigos extratextuais, que ajudam o leitor a entender a situação comunicativa do discurso ficcional. Quando Aluísio elaborou a nota Antes de principiar, utilizou uma linguagem individualizada para dialogar com os leitores da publicação seriada, já, na versão em livro, que atinge uma dimensão social mais ampla, a nota foi suprimida.

Duas publicações envolvem diferentes estâncias de leitura de mundo, porque nem mesmo os documentos que envolvem o processo de produção das duas versões de Casa de Pensão e os jornais da época desvendam todos os códigos extratextuais do romance ou sua dialogia externa. No entanto, por intermédio do texto artístico, a leitura de um microcosmo da sociedade carioca pode ser feita em diferentes épocas, a partir da compreensão intratextual, limitada ao que o formato em livro conseguiu absorver e cristalizar na linguagem literária.

Pertencente a um universo pouco conhecido para os leitores que somente têm acesso à variante em livro, Casa de Pensão, no formato de romance-seriado, contém especialidades do processo de criação do discurso ficcional, ligadas ao gênero da publicação, periodicidade quase que diária e cortes sistemáticos. Essas características nos levam à apresentação das principais informações ligadas a cada uma das seqüências localizadas, ao mesmo tempo em que nos permitem aplicar alguns dos exemplos representativos da metodologia elaborada por Ribeiro (1996; 2000). Com o resultado dessa abordagem, torna-se possível verificar as técnicas composicionais de Casa de Pensão para o jornal, como forma de interpretar as técnicas utilizadas por Aluísio Azevedo na primeira versão desse romance.

No período que vai do dia 06 de março a 22 de maio de 1883, o jornal Folha Nova - RJ publica os dez primeiros capítulos e parte do décimo primeiro do romance Casa de Pensão. No dia 30 desse mesmo mês, Sá Pinho informa aos leitores do 
jornal O Mequetrefe (RJ) que "Aluísio Azevedo tem empregado o máximo esmero na elaboração desta obra, e a Casa de Pensão vai ser talvez o primeiro estudo sério que se tenha feito entre nós, na esfera do romance". No mês seguinte, no dia 10 de junho, O Mequetrefe, em texto assinado por K. Loiro, anuncia a publicação de um fascículo do romance, no entanto, não tivemos acesso a essa variante, tendo em vista que a próxima versão localizada é a em livro (popular), lançada em 1884, por Faro \& Lino Editores, cuja estrutura apresenta vinte e dois capítulos.

No jornal Folha Nova, o romance é introduzido pela nota Antes de principiar, publicada no dia 05 de março de 1883, na véspera da publicação da primeira das quarenta seqüências do romance-seriado.

As quarenta seqüências encontradas na Biblioteca Nacional - RJ representam grande parte da publicação em jornal e possibilitam a aplicação do procedimento proposto para a análise dessa variante, a partir de exemplos representativos de todas as seqüências. $\mathrm{Na}$ análise do romance-seriado, as técnicas da narrativa folhetinesca revelam as estratégias textuais utilizadas por Aluísio para a composição de cada seqüência do romance, conforme pode ser observado a seguir.

Além de seguir as tendências adotadas pelo mercado editorial de sua época, ora lançando seus romances na seção folhetim de algum jornal, ora adequando o texto para o formato de livro, Aluísio Azevedo é considerado um dos poucos escritores brasileiros a fazer da literatura e do jornalismo duas profissões. No universo artístico de Azevedo, essas duas modalidades estão profundamente associadas, seja no momento de selecionar informações, elaborar os textos, divulgar romances-folhetins ou estruturar um livro. Essa estreita relação contribuiu para que os discursos se fundissem, resultando em uma nova linguagem, híbrida, entre literatura e jornalismo.

\subsection{Capítulo I - dois segmentos}

\subsubsection{Primeira seqüência: 06 de março (01)}




\subsubsection{Principais ações desta seqüência}

Coluna 01 - Início: a marca temporal "Seriam onze horas da manhã" descreve o momento em que Campos, o primeiro personagem a ser apresentado, desce do almoço. Depois do tempo, é apresentado o espaço de trabalho, em que havia grandes livros de escrituração mercantil ${ }^{8}$, uma escrivaninha, prensa de copiar, dentre outros objetos.

Colunas 02 e 03 - O comerciante está escrevendo uma carta, quando um rapaz [Amâncio] o interrompe, "perguntando se podia falar com o Sr. Luiz Batista de Campos". O jovem de 20 anos é descrito como um tipo do Norte do Brasil, levemente estrábico, que ostentava sua riqueza pelas jóias que usava. Os dois se apresentam.

Coluna 04 - Amâncio entrega a Campos uma carta escrita pelo pai, o Sr. Vasconcelos, na qual este solicitava que o comerciante, que tinha sido sócio do tio do seu irmão, ajudasse o filho a fixar-se na Corte. Essa era apenas uma das inúmeras cartas de recomendação que Amâncio ainda precisava entregar.

Colunas 05 - A casa comercial de Campos é descrita minuciosamente. No térreo, era o armazém, no primeiro andar, o escritório e, no segundo andar, era onde o guarda-livros morava com a mulher - Hortênsia e uma cunhada - Carlotinha.

Coluna 06 - São descritos os hábitos de Campos. O final desta seqüência revela que Campos: "nos dias de descanso dava-se todo ao Figuier, ao Flammarion ${ }^{9}$ e ao Júlio Verne ${ }^{10}$; outras vezes", poucas, atirava-se à literatura francesa, mas os verdadeiros mestres do romance o aborreciam com o seu estilo compacto e cerrado".

\footnotetext{
${ }^{8}$ Obras do período: 1878 de Jerônimo Joaquim de Oliveira "Compêndio - Comercial - Tratado Prático de Direito e Escrituração Mercantil”; 1880 de Ildefonso de Souza Cunha - Guia teórico - prático de escrituração mercantil.

${ }^{9}$ Os cientistas Louis Figuier e Camille Flammarion foram dois dos principais e mais renomados divulgadores científicos da segunda metade do século XIX. Louis Figuier renunciou à carreira científica para dedicar-se à criação do teatro científico. Autodidata, Camille Flammarion tornou-se astrônomo e publicou a obra especializada: Tratado de Astronomia.

${ }^{10}$ Júlio Verne foi um dos primeiros escritores a dedicar-se à escrita da moderna ficção científica, tal como: "Cinco Semanas em um Balão" (1863), "Viagem ao Centro da Terra", "Da Terra à Lua" (1865), "Vinte Mil Léguas Submarinas" (1869) e "A Volta ao Mundo em 80 Dias" (1872).
} 


\subsubsection{Técnicas básicas do padrão narrativo do romance-seriado}

O romance-seriado inicia-se com a frase: "seriam onze horas da manhã". Para Ribeiro (2000, p. 166), essa marca temporal "procura indicar logo ao leitor o marcador do tempo ficcional em questão", além disso, essa expressão indica a presença de "uma voz narrativa que assume um tom bem coloquial". Outra técnica narrativa notada refere-se ao início "sem muitos preâmbulos, contendo referência direta à hora da história". Apesar de ser inserida indiretamente a referência do mês, pressupomos que se trata de fevereiro ou março, pois fazia muito calor e, nessa época, o período letivo já havia começado.

Enquanto o final desta seqüência apresenta a informação de que a leitura dos grandes mestres do romance aborrecia Campos, "com o seu estilo compacto e cerrado", a versão em livro revela que o descontentamento está ligado aos "rigorismos da forma".

\subsubsection{Segunda seqüência: 07 de março (2)}

\subsubsection{Principais ações desta seqüência}

Coluna 01 - O primeiro parágrafo, que marca o início desta seqüência, foi suprimido no livro: "O fato é que era [Campos] um excelente homem. Percebiam-se-lhe os bons desejos e as justas intenções; descobria-se o esforço que ele empregava pra se distinguir o mais possível dos colegas grosseiros e marialões".

Coluna 02 - A vida profissional estava em harmonia com a familiar, em meio à organização e à limpeza, o que era mantido graças à sua determinação e às qualidades encontradas na mulher Hortênsia. Campos "sentia-se bem no meio dessa ordem, desse método".

Coluna 03 - Conteúdo que somente existiu no romance-seriado: "De Ponsos a Pilatos [Campos] com uma mão atrás a outra adiante!... Diziam alguns colegas invejosos" [...]. Não tinha mais de 36 anos de idade e era "assombroso" o modo como Campos prosperava. Há um diálogo que expressa os comentários que os vizinhos faziam a seu respeito, alguns o invejavam, outros o elogiavam. 
Coluna 04 - "E assim ia Campos. Amaldiçoado por uns, bem ausentado por outros, ora elogiado, ora mal falado, mas sempre a caminhar, sempre a prosperar". No livro, esse texto é resumido da seguinte forma: "E o caso era que o Campos, ou devido à fortuna ou ao bom tino para os negócios, prosperava sempre". Amâncio retorna à casa do comerciante para jantar, às quatro horas da tarde, quando o jovem já não conseguia entregar as últimas cartas, pois o calor o fatigava.

Coluna 05 - Enquanto Amâncio está na sala de visitas, Hortênsia tenta convencer Campos a não receber o maranhense, dizendo que "meter estudantes em casa é o diabo". Campos justifica que precisa receber o jovem para pagar os favores que devia à família Vasconcelos, que o acolheu no Maranhão. Ele acrescenta que "ele até parece tolo". É acrescentada a informação de que Campos é cearense, por isso hospitaleiro.

Coluna 06 - O final desta seqüência é surpreendente. Se nas colunas anteriores, Maria Hortênsia mostrava desaprovar a atitude do marido de acolher o jovem, durante o jantar ela passou a se dirigir a ele com um sorriso afável nos lábios. Enquanto isso, Amâncio observava Carlotinha: "não a perdera de vista e, com o seu espírito perspicaz de maranhense, entrava-lhe pelos ouvidos e ia mexer-lhe a alma" [Apenas o romance-seriado apresenta a informação destacada]. Às sete horas, o nortista vai para o hotel "Coroa de ouro", tenta dormir, mas não consegue deixar de ver o vulto de Hortênsia a lhe sorrir, "estendendo-lhe no ar os belos braços, brancos e carnudos". Ao dormir, são interrompidos os relatos sobre as duas mulheres, que haviam mexido com Amâncio naquela noite e, assim, instaura-se um suspense.

\subsubsection{Técnicas básicas do padrão narrativo do romance-seriado}

A conexão estabelecida com o segmento anterior possibilita a continuidade das descrições apresentadas. Há explicações sobre a ascensão profissional do comerciante, sua feição pelos livros e as conquistas adquiridas pelo trabalho.

Da segunda até a quarta seqüência, é privilegiada a descrição de Luís de Campos, comerciante português amigo da família Vasconcelos, para a qual devia favores. No romance-seriado, diz-se que "apesar de brasileiro, Campos nunca 
conseguiu espantar de sua casa o ar triste que a ensombrecia", ao passo que na publicação em livro, o comerciante recebe os atributos de brasileiro e inteligente. Apesar de serem apresentadas com detalhes as qualidades do comerciante, a "ausência da descrição psicológica" nos impede de realizarmos qualquer julgamento sobre o porquê de Campos não conseguir espantar o ar triste de sua casa.

O conteúdo da terceira, quarta e quinta colunas é apresentado por meio de diálogos. O final desta seqüência é igual ao apresentado em livro.

A técnica de "priorizar a ação dos personagens com o recurso de expressão para esse fim" (RIBEIRO, 1996, p. 45) pode ser notada na sexta coluna, quando Amâncio, "com o seu espírito perspicaz de maranhense, entrava-lhe pelos olhos e ia mexer-Ihe a alma [de Carlotinha]".

\subsection{Capítulo II - quatro segmentos}

\subsubsection{Primeira seqüência: 08 de março (3)}

\subsubsection{Principais ações desta seqüência}

Coluna 01 - Início: Há um deslocamento espacial. Amâncio deixa o hotel para instalar-se na casa de Campos. Nessa altura, também realiza uma reflexão sobre suas primeiras impressões acerca do Rio de Janeiro.

Coluna 02 - O aspecto infantil e os traços delicados de Amâncio camuflavam seu lado dissimulado e fingido, como conseqüência dos castigos recebidos do pai e do professor. E só encontrava refúgio nos braços da mãe, Ângela. Apenas o romanceseriado contém essa informação a propósito do pai: "[...] trabalhador como um herói, mas bruto como um burro. Amava muito o filho, mas entendia que lhe não podia dar melhor prova de estima do que ministrando de vez em quando alguns pontapés, quando o rapaz fazia das suas".

Coluna 03 - Aos sete anos Amâncio inicia os estudos. No início, o menino tenta afrontar o professor Pires, mas o medo do castigo o faz disfarçar seu ódio, porque os pais "ignorantes, viciados pelos costumes bárbaros do Brasil, atrofiados pelo hábito 
de lidar com escravos, descobriam naquele bruto o unido professor capaz de endireitar os filhos".

Coluna 04 - Quando tinha oito anos, um colega de classe provoca Amâncio, ofendendo sua mãe. Esse insulto instaura grande conflito. Isso era relembrado pelo professor, sempre que dizia ao Vasconcelos que "aquela criança the havia de dar muito desgosto".

Coluna 05 - "De repente, ouve-se o estalo de uma bofetada" [no colega que o ofendera há pouco]. Depois de castigar Amâncio, Pires pede para que o garoto que havia recebido a bofetada "aplicasse mais outras tantas palmatoadas" no colega.

Coluna 06 - Como Amâncio diz que não irá se submeter ao castigo, o professor fica nervoso e deixa "escapar a mesma frase que pouco antes promovera tudo aquilo". "Amâncio recuou dois passos e soltou em cheio a mão no rosto do mestre. Depois fugiu, a correr". Seguindo as ordens do professor colérico, cinqüenta condiscípulos perseguiram Amâncio até levá-lo à presença do professor. Amâncio sofreu um novo castigo. Quando chegou em casa, o pai "deu-lhe nova sova e obrigou-o a pedir perdão de joelhos ao professor e ao menino da bofetada". Desde então, todo o sentimento de justiça se transformou em ódio. Esta seqüência termina com Ângela beijando o filho antes de dormir: "dissera-lhe, com uma lágrima nos olhos, que ele fizera muito bem".

\subsubsection{Técnicas básicas do padrão narrativo do romance-seriado}

$\mathrm{Na}$ primeira coluna, o personagem Amâncio descreve suas primeiras impressões acerca do Rio de Janeiro. O maranhense esperava que a cidade fosse uma espécie de Babilônia, onde a libertinagem podia correr solta, com a exploração da "temática dos vícios e amor selvagem". O conteúdo em livro apresenta o espaço comparado a Paris, que conhecia através das de feitas por Dumas e Paulo de Kock, escritores franceses que retrataram problemas sociais por intermédio da ficção. Nas duas versões, a cidade é vista como um lugar de se viver à vontade, com liberdade e sem medo de escândalos.

Com a técnica de "conduzir para trás" (RIBEIRO, 1996, p. 45), o personagem remete-se ao "mestre, um tal José Antônio Pires, homem grosseiro, bruto, de cabelo 
negro e olhos de touro, batia nas crianças por gosto, por um hábito do ofício" ( $3^{a}$ coluna). O vilão é descrito com "traços grosseiros e satânicos". Esse professor falava a berrar "como se dirigisse uma boiada". O professor foi uma espécie de carrasco na vida do protagonista, uma vez que seus castigos e tratamentos severos foram grandes responsáveis por Amâncio ter se tornado um sujeito hipócrita. De acordo com Menezes (1958, p. 55), o autor utiliza no romance-seriado o nome do antigo professor José Antônio Pires, tão carrasco quanto o vilão ficcional. Essa analogia se remete à técnica narrativa da "verossimilhança que nunca escorrega para o irracional" [...] porque há "uma explicação real para a verossimilhança dos fatos".

Há um "lance teatral" na classe do Pires. As bofetadas, uma dada por Amâncio no colega e a outra no mestre, causam grande confusão. Esse episódio é retomado pelo professor sempre que o Pires tenta alertar Vasconcelos para o aborrecimento que o filho Ihe daria, como se antecipasse o desfecho da história.

Nesta seqüência, também podemos notar a presença da técnica de construção narrativa da "estética divergente e centrífuga", que engloba a mudança de Amâncio para a casa de Campos; as primeiras lembranças do Maranhão, com a visão idealizada da mãe e desejo de vingança que sentia sempre que as imagens do pai e do professor Pires vinham à sua mente. Apesar da multiplicidade temática, todos esses pontos estão ligados à explicação de como se formou o caráter do personagem. O final desta seqüência é feito durante a narração de eventos ocorridos na infância de Amâncio, o que provoca suspense até a retomada desse assunto no próximo seguimento.

\subsubsection{Segunda seqüência: 09 de março (4)}

\subsubsection{Principais ações desta seqüência}

Coluna 01 - Início: há um acoplamento de idéias, que se dá pela explicação dos efeitos que o castigo provocara na vida do personagem: "Esses pequenos episódios da infância, tão insignificantes na aparência, decretaram todavia a direção que tinha de tomar o caráter de Amâncio".

Coluna 02 - "E Amâncio dominava-se, fazia-se sério por medo de apanhar". "Por essa forma foi se tornando reservado e fingido". 
Coluna 03 - "Tudo isso foi o esterco onde desabrochou no seu temperamento o leite escravo que lhe deu de mamar a preta que Ihe serviu de ama". Essa referência provoca um recuo ainda maior no tempo do romance, que passa a revelar os momentos que antecederam e precederam o nascimento de Amâncio.

Coluna 04 - A técnica narrativa de "conduzir para trás" surge novamente nesta coluna. Os castigos, somados ao fato de que sua ama de leite tinha problemas de saúde, remetem-nos à advertência do médico: "- Esta mulher tem reuma no sangue, dizia ele, e a criança pode vir a sofrer no futuro". Amâncio "era muito feio de pequeno. Um nariz disforme, uma boca sem lábios e dois rasgões no lugar dos olhos. Não tinha um fio de cabelo e estava sempre fazendo caretas".

Coluna 05 - "Ângela adorava-o com o entusiasmo do primeiro parto". "A avó, uma quase analfabeta, supersticiosa e devota, permitia-Ihe todas as vontades e morria de amores por ele". E Amâncio se aproveitava muito dessa predileção.

Coluna 06 - Como um pedido de Amâncio era suficiente para que a avó suspendesse os castigos dados aos negros, os escravos da fazenda tratavam Amâncio como "um pequeno Deus, caprichoso e colérico. Suportavam sorrindo todas as duas diabruras e cumpriam os seus desejos, como se eles fossem ordens irrevogáveis" [esta última citação é suprimida da versão em livro]. Só aos onze anos, fez o seu exame de português na aula do Pires [...] foi aprovado plenamente, mas não sabia nada; quase não sabia ler". O Lyceu, nova etapa da vida acadêmica para Amâncio, representava ficar longe do castigo. A conclusão desta seqüência é feita com as projeções de Amâncio: "só de se lembrar que já não estava ao alcance das garras do Pires, o coração saltava-Ihe de alegria". No livro, o Pires é classificado como maldito e é "uma alegria nervosa" que está associada ao sentimento de liberdade.

\subsubsection{Técnicas básicas do padrão narrativo do romance-seriado}

A "estética divergente e centrífuga" e a "técnica narrativa de conduzir para trás" apresentam as informações relacionadas tanto com os quatro anos que Amâncio fora aluno do Pires, quanto ao recuo, mais ainda no tempo, que focaliza o nascimento do protagonista e sua nova fase no Lyceu, aos quatorze anos. 
As colunas um e dois apresentam a "fisionomia interior do personagem", na quatro, a fisionomia de recém-nascido é delineada com traços fixos, os defeitos exagerados. Todas as seis colunas desta seqüência apresentam informações importantes para o desenvolvimento narrativo e a posição ocupada por Amâncio em diversas situações dentro da intriga. Sua debilidade infantil servirá de gancho para o início do décimo terceiro segmento, quando é inserida a explicação do que o prendeu por três anos na casa da avó, atrasando a conclusão dos estudos, preenchendo lacunas deixadas na primeira seqüência. Esse "didatismo narrativo" é característico no romance-seriado e fundamental para a compreensão dos cortes e ganchos feitos, não apenas com as seqüências anteriores e posteriores, mas com todos as partes que integram a diegese de Casa de Pensão.

\subsubsection{Terceira seqüência: 10 de março (5)}

\subsubsection{Principais ações desta seqüência}

Coluna 01 - Início: "Vasconcelos quis festejar o exame do filho com um jantar".

Coluna 02 - Mais uma vez, há um recuo do tempo para dizer que "- já em pequeno era [Amâncio] muito sabido, muito esperto!". Com pesar, Ângela refletia sobre o fato de que não teria seu filho perto de si para sempre.

Coluna 03 - Com ar superior, Amâncio revela a um dos convidados que irá ingressar na Marinha.

Coluna 04 - "Amâncio nunca mais voltou a passear na fazenda da avó. Agora gostava mais de ficar na cidade. Tinha namoros [...] fumava, fazia pandegas com os colegas do Lyceu".

Coluna 05 - A liberdade encontrada quando fugia à noite parecia "Ihe sorrir por um prisma voluptuoso e romanesco".

Coluna 06 - Seus pensamentos são embalados pelas lembranças de cenas lidas em livros românticos e pela música que lembrava os Girondinos de Lamartine. O final 
desta seqüência ocorre com a convicção de Amâncio de que era preciso viver livremente outro mundo, por isso decidiu partir para o Rio de Janeiro, onde poderia viver "aventuras inesperadas e amores, amores principalmente".

\subsubsection{Técnicas básicas do padrão narrativo do romance-seriado}

A quarta coluna retoma a informação já apresentada na última coluna da seqüência anterior, dando continuidade aos relatos sobre a trajetória acadêmica de Amâncio. Essa correlação de informações possibilita o desenvolvimento da seqüência anterior, ligando a aprovação de Amâncio à festa para comemorar sua aprovação na avaliação do Pires.

O final desta seqüência é inconsistente, se comparado com os inúmeros fatos relatados nas seis colunas que lhe integram. As lembranças tidas com a primeira bebedeira, durante a festa oferecida por seu pai, e as outras que a precederam fazem uma cronologia da vida boêmia que Amâncio levava no Maranhão. A voz do narrador acrescenta que Amâncio buscava a liberdade idealizada com a vida na Corte.

Enquanto o romance-seriado apresenta esses fatores para explicar o porquê de sua "vinda para o Rio de Janeiro", o livro os coloca como justificativa para Amâncio deixar o Maranhão e "ter de seguir para o Rio de Janeiro". O ponto final é substituído por um ponto de exclamação para encerrar esta seqüência.

\subsubsection{Quarta seqüência: 11 de março (6)}

\subsubsection{Principais ações desta seqüência}

Coluna 01 - Início: "Desde bordo principiou a gozar do efeito que a novidade de sua viagem produziu-lhe no espírito. Amâncio está a bordo do navio que o levaria à Corte". 
Coluna 02 - O personagem lembra-se do sofrimento que a despedida causou em sua mãe. No entanto, ele achava que já estava indo tarde.

Coluna 03 - Ângela ficou doente nos dias que antecederam à partida do filho. "No dia da viagem não se pode levantar da cama [...]".

Coluna 04 - E a "lembrança do dinheiro puxou logo outros consigo; voltaram os seus sonhos de prazer, as suas fantasias românticas". Dos quinze anos até sua partida tinha vivido muitos amores, mas achava que só estas três mereciam ser lembradas: a filha do Costa Lobo, a mulher de um comendador e uma viúva.

Coluna 05 - Amâncio tinha 16 anos, "estava cheio de tolice" quando a mulher de um comendador o encaminhou. Porém, não podia deixar de reconhecer que a filha do Costa levava vantagem pela primazia em beleza, em frescura, em novidade. "Ela às vezes chorava".

Coluna 06 - "Já não era assim a viúva. Muito mais séria, romântica, só falava escolhendo termos com os olhos revirados, a voz sibilada. Amâncio custou alcançála, mas depois viu-se perseguido: a viúva era muito ciumenta. Fazia cenas, afetava crises histéricas, gostava de agatanhar, descompor, dizer impropérios. Amâncio achava que das três era a mais inteligente, mas espirituosa, mais metida a literata".

Coluna 07 - Todo o conteúdo desta coluna está mutilado, assim como o final de todas as outras colunas desta seqüência.

\subsubsection{Técnicas básicas do padrão narrativo do romance-seriado}

$\mathrm{Na}$ vertente em livro, são suprimidos os detalhes sobre os primeiros amores de Amâncio. Embora parte do documento esteja mutilada, ainda é possível ler grande parte das informações sobre as primeiras experiências amorosas do protagonista:

Não sabia qual das três era o melhor [amor] $\left(.^{11}\right)$ ao restaurante do Porto. Sentaram-se ao lado um do outro; no meio do céu já brincavam com os pés, e no dia seguinte cartearam-se.

Amâncio teria dezesseis anos, estava ainda cheio de tolice; ela o encaminhou.

\footnotetext{
${ }^{11}$ Parte mutilada.
} 
Como foram felizes. Como foram! Com que prazer não saltava ele o muro do quintal para ir falar-lhe à meia noite por debaixo da janela de seu quarto, ao clarão melancólico da lua ou das estrelas.

Foi a sua primeira paixão, foi a sua primeira conquista séria, tinha saudades dela. Mas a filhinha do Costa Lobo!!

Se a mulher do comendador levava vantagem nas salas, nas toilettes, no luxo, a filhinha do Costa Lobo tinha a primazia em beleza, em frescura em novidade.

Era quase criança; todos a supunham inocente. Amâncio para falar-lhe tinha de subir por uma escada de cordas, que ela prendia à janela.

As entrevistas eram na cozinha, pela madrugada quando toda a casa dormia. Amâncio sentava-se em um degrau do fogão, que era de barro, dos primitivos.

Havia sempre muito sobressalto, muito susto. Ela às vezes chorava.

Uma tia da menina $\left(.{ }^{12}\right)$.

Já não era assim a viúva. Muito mais séria, romântica, só falava escolhendo termos, com os olhos revirados, a voz sibilada. Amâncio custou alcançá-la, mas depois viu-se perseguido; a viúva era muito ciumenta. Fazia cenas, afetava crises histéricas, gostava de agatanhar, descompor, dizer impropérios.

Amâncio achava que das três era a mais inteligente, mais espirituosa, mais metida a literata $\left(4^{\mathrm{a}}, 5^{\mathrm{a}}\right.$ e $6^{\mathrm{a}}$ COLUNAS).

Os três amores são relatados em lances teatrais. Os espaços de São Luís integram o cenário dos amores proibidos: Amâncio precisava pular um muro à meia noite para se encontrar com a mulher de um comendador; de madrugada, subia por uma escada de cordas até a janela da casa da filhinha do Costa Lobo; quanto à viúva, os obstáculos eram feitos por ela, que dificultava a conquista. Todas as aproximações são cercadas por lances teatrais, em meio a dificuldades, obstáculos, que são recompensados pela conquista de seus amores.

Há uma particularidade estrutural nesta seqüência, que consiste na distribuição do conteúdo em sete colunas, ao passo que a maioria dos segmentos apresenta seis.

\subsection{Capítulo III - cinco segmentos}

\subsubsection{Primeira seqüência: 12 de março (7)}

\footnotetext{
${ }^{12}$ Ibidem.
} 


\subsubsection{Principais ações desta seqüência}

Coluna 01 - Início: "Amâncio, graças aos esforços de Campos, matriculou-se quinze dias depois de sua chegada". Desde o primeiro contato com o curso de Medicina: "Compreendia perfeitamente que nunca viria a ser um bom médico: nunca amaria perfeitamente a sua profissão".

Coluna 02 - "Às vezes, contudo, pretendia reagir [...] disposto a ler horas consecutivas [...]. Mal, porém, ele se agarrava aos compêndios, o pensamento, pé ante pé, ia-se escapando da leitura, descia sorrateiramente ao chão e fugia pela janela do quarto, para ganhar a rua e prender-se na primeira saia que encontrasse".

Coluna 03 - "E não haver uma academia de direito no Rio! Se houvesse! Então é que seriam elas!" [...] "E Amâncio revoltava-se cada vez mais com a Medicina”.

Coluna 04 - "A mãe tinha toda razão. Era preciso fazer-se doutor". Só de lembrar-se da mãe, logo sentiu vontade de estar ao seu lado. "A despeito do seu desenvolvimento do corpo, sua alma fazia-se muito pequena, muito criança e chorava".

Coluna 05 - "Minha querida mãe. Eis-me na grande corte! a qual me parece insípida e acanhada porque estou longe de vocemecê". Seguia-se uma descrição da cidade, que ocupou duas laudas da carta.

Coluna 06 - "E a carta continuava neste teor, até encher duas folhas de papel marca pequena. Amâncio aí contava à mãe todos os seus passos e todos os seus desgostos [...]". "Luiz Campos, o qual já se lhe ia tornando perfeitamente insuportável com a sua grande seriedade de mentor, a sua voz medida e discreta, os seus gestos sóbrios, enfim, o seu todo repreensivo e pedagógico".

O final desta seqüência ocorre com o basta que o estudante quer dar ao controle exercido sobre ele: "- Ora adeus! dizia Amâncio consigo, furioso - Não foi para isso que vim ao Rio de Janeiro! Boas!" 


\subsubsection{Técnicas básicas do padrão narrativo do romance-seriado}

Nesta seqüência, há abundância de solilóquios, nos quais o protagonista reflete sobre a impossibilidade de cursar Direito na Corte, a dificuldade de ser um bom aluno e bom médico. Novos pensamentos interiores justificam os motivos que o impulsionaram a ir ao Rio de Janeiro. Queria estudar Direito por admitir sua falta de talento pelas matérias exatas e seu desapreço completo pela Medicina. Porém, se Amâncio quisesse verdadeiramente ser um advogado, poderia ter ficado no Maranhão.

Diferente da versão em livro, o romance-seriado apresenta repetição de conteúdos, na coluna dois e na três, para enfatizar o descontentamento de Amâncio por não existir academia de Direito no Rio de Janeiro: "- Não haver uma academia de direito no Rio de Janeiro!" ( $2^{a}$ Coluna); "E não haver uma academia de direito no Rio!" ( $3^{a}$ coluna). Nas colunas dois e três os solilóquios marcam as reflexões acerca da idéia de Amâncio ser ou não médico.

O pensamento sobre as profissões insere a técnica de "conduzir para trás", e novamente vem-lhe à mente a imagem do pai, que "nunca tomou a sério os artistas". Segundo Vasconcelos, a melhor maneira era conseguir cobres e ter à disposição os melhores artistas. Nessa mesma concepção, Amâncio pensava que tinha dinheiro o bastante para contratar os melhores médicos e, assim, não precisaria estudar para ser um. No entanto, quando se lembra do quanto sua mãe desejava vê-lo formado, "fosse lá como fosse", o personagem tenta convencer-se de que era preciso ser doutor. Em solilóquios, começa a ligar o título ao nome: - Doutor Amâncio.

Há uma supressão temporal dos quarenta e cinco dias posteriores à chegada de Amâncio ao Rio de Janeiro. A primeira marca temporal refere-se ao encontro entre Amâncio e Campos; a segunda, à informação de que: "Amâncio, graças aos esforços de Campos, matriculou-se quinze dias depois de sua chegada"; a terceira é registrada na carta escrita à mãe, na qual Amâncio relata tudo o que Ihe acontecera no primeiro mês e meio em que estava hospedado na casa de Campos. 


\subsubsection{Segunda seqüência: 14 de março (8)}

\subsubsection{Principais ações desta seqüência}

Coluna 01 - Início: "Podia lá estar disposto a aturar a noite aquele maçante Campos?!...". "Por isso ficou muito satisfeito uma manhã em que, passando pelo beco do Cotovelo, deu cara a cara com o Paiva Rocha".

Coluna 02 - "E Amâncio prosseguia: - que não achara graça nenhuma na tal corte!"

Coluna 03 - Quando Amâncio viu em Paiva, um ímpeto de raiva "começou a falar sobre dinheiro". "- E sacudiu as algibeiras. - Isso arranja-se, disse Amâncio timidamente, com medo de humilhar o outro [...]".

Coluna 04 - "Paiva olhou muito sério para ele, e espocou depois uma risada falsa".

Coluna 05 - "E [Paiva] fazia-se muito emprenhado nos interesses do amigo, davaIhe conselhos, havia de abrir-Ihe os olhos, indicar-Ihe o verdadeiro caminho".

Coluna 06 - Final: "Aceitaram [o convite de Amâncio]. E os quatro rapazes seguiram alegremente para o hotel, a rir e a conversar, como se fossem todos amigos de muito tempo".

\subsubsection{Técnicas básicas do padrão narrativo do romance-seriado}

No momento em que Amâncio reflete sobre a necessidade de deixar a casa de Campos e viver livremente sem ser vigiado, pergunta a si mesmo [e talvez ao leitor] se: "Podia lá estar disposto a aturar à noite aquele maçante Campos?!". No livro há apenas a exclamação.

Enquanto o protagonista mergulha em um solilóquio, é surpreendido pelo "acaso" de encontrar Paiva [condiscípulo do Pires]. A partir disso, o espaço das ruas do Rio de Janeiro é enfatizado como palco do diálogo, que mais parece um monólogo, pois Amâncio não cessa de falar da desilusão sentida na Corte. Se, no início, Paiva queria livrar-se de Amâncio, a partir do momento em que o conterrâneo passou a falar de dinheiro, Paiva mostrou-se muito afável. Neste ponto, Amâncio 
inicia seu processo de reificação, que culminaria em sua morte e transformação como coisa, como marca: "O velho leu distintamente" "Amâncio de Vasconcelos". É o título! Disse [à mãe de Amâncio]. - Eles agora batizam as mercadorias com os nomes que estão na moda. Algum tenor!" (CP, 1977, p. 191).

\subsubsection{Terceira seqüência: 15 de março (9)}

\subsubsection{Principais ações desta seqüência}

Coluna 01 - Início: "Paiva pediu um gabinete particular e instalou-se aí com os amigos".

Coluna 02 - "Este Paiva é terrível para um menu! observou o Simões em ar de troça". "E parecia querer provar que os seus direitos sobre o Amâncio eram muito mais legítimos que os dos outros dois, que Amâncio Ihe pertencia, era um tesouro seu $[\ldots] "$.

Coluna 03 - "O almoço tornava-se alegre. João Coqueiro propôs um brinde a Amâncio e declarou, depois de fazer-Ihe muitos elogios, que estimaria imenso ser recebido no rol de seus amigos".

Coluna 04 - "E [Coqueiro], puxando a cadeira para mais perto de Amâncio, falou-lhe em voz baixa. Disse que no Rio de Janeiro era preciso ter um amigo sincero, não que primasse nos menus, mas que fosse sério, que tivesse imputabilidade moral. Que Amâncio estava defronte de duas estradas: uma que conduzia à verdadeira felicidade e outra para a desordem, para o vício e para a completa desmoralização. Não se deixasse levar pelos pândegos: aquilo era gente sem nada a perder".

Coluna 05 - "- Menino! disse-lhe o Paiva. - vai tratando de aproveitar, porque é isso o que se leva d'este mundo! Amâncio fazia-se fino, perigoso, e continuava a falar expansivamente um pouco agitado pelo almoço. Coqueiro o ouvia com muita atenção, em silêncio [...]". 
Coluna 06 - "- E como lhe digo, explicava este - aquilo não é um hotel, é uma casa de família! Nós não temos hospedes, temos amigos! Minha mulher é quem toma conta de tudo! [...]".

O final instaura um suspense: "Mas a porta abriu-se com empuxão, e uma mulher loura, gorda, vestida de seda amarela, precipitou-se no gabinete, espavorida, a soltar gritos".

\subsubsection{Técnicas básicas do padrão narrativo do romance-seriado}

O início desta seqüência apresenta continuidade com a anterior. Se, por um lado, os espaços abertos das ruas também marcam o encontro de Simões e Campos, colegas de Paiva da Escola Politécnica, por outro, o espaço fechado do restaurante propicia a aproximação de Coqueiro que, ao perceber que o novo amigo é rico, tenta ganhar sua confiança.

No livro, o termo "amigos", que aparece na primeira coluna, é substituído por "outros", como se Amâncio fosse o único amigo de Paiva e os outros fossem apenas colegas. Para acentuar o significado dessa alteração, citamos que Paiva: "parecia querer provar que os seus direitos sobre o Amâncio eram muito mais legítimos que os dos outros dois, que Amâncio Ihe pertencia, era um tesouro seu [...]". No livro (CP, 1977, p. 35), esta passagem sofre alterações significativas: "E parecia querer provar que os seus direitos sobre o comprovinciano eram muito mais legítimos que os dos outros dois, que Amâncio lhe pertencia quase exclusivamente, como uma fortuna que se traz no berço". Nas duas versões, fica claro que "a situação social insatisfatória" de Paiva poderia ser melhorada diante do compromisso que Amâncio Ihe fizera de ajudá-lo financeiramente.

Se, no romance-seriado, Amâncio apenas ouve os conselhos de Paiva: “— vai tratando de aproveitar, porque é isso o que se leva deste mundo!", no livro, Amâncio expressa compartilhar desse pensamento: “- E o mais são histórias!... concluiu o filho de Vasconcellos" (CP, 1977, p. 37).

A técnica folhetinesca de inserir "vilões da história com traços grosseiros e satânicos", já utilizada para caracterizar o professor Pires, também pode ser aplicada a Coqueiro, o antagonista de Casa de Pensão. Durante o almoço pago por Amâncio, Coqueiro: "Era o único que não estava tonto, seus olhos, pequenos e de cor incerta, 
conservavam a mesma penetração e a mesma fixidez incisiva. Sua boca quase sem lábios e guarnecida de bons dentes tinha o mesmo riso arqueado, indeciso e frio". 0 conteúdo em livro registra que Coqueiro estudava Amâncio de maneira dissimulada, a seguir-lhe os gestos e tentando entender suas intenções. Por essas razões, na variante em livro, é comparado a uma ave de rapina, acentuando a técnica da narrativa folhetinesca.

O final desta seqüência instaura grande suspense e expectativa quanto à continuidade da história. O corte repentino quebra o ritmo narrativo e interrompe duas ações: a persuasão de Coqueiro sobre Amâncio e uma briga causada por outros clientes do restaurante. Segundo Ribeiro (1998, p. 44-46), o "corte no desenvolvimento da história" redireciona o discurso narrativo.

A técnica narrativa com os "lances teatrais" também pode sugerir a "linha de ação quebrada dos personagens", pois todos representam o papel que convém a cada um durante o almoço. Em todas as colunas desta seqüência há "abundância de diálogos", como marca da oralidade.

\subsubsection{Quarta seqüência: 16 de março (10)}

\subsubsection{Principais ações desta seqüência}

Coluna 01 - Início: "Vinha perseguindo um sujeito idoso, cheio de corpo, o chapéu atirado para a nuca; o olhar desvairado e convulso".

Coluna 02 - "Paiva atirou-se-lhe à pista, mas o gerente do hotel meteu-se entre eles, pedindo aquele por amor de Deus que não fizesse caso, e deixasse lá os dois se esbordoarem".

Coluna 03 - "Amâncio aconselhou ao Braz que bebesse alguma cousa, e derramouIhe vinho no copo".

Coluna 04 - "E Coqueiro, já de chapéu na cabeça e guarda-chuva debaixo do braço, foi apertar-Ihe a mão [de Amâncio], dizendo que folgava muito em haver travado com ele relações, e que o esperava sem falta no domingo". 
Coluna 05 - "- Pois que repare! Manda plantar batatas o tal Campos! Tu não és nenhum caixeiro dele. Eu, no teu caso, nem ficava ali mais um dia! É estúpido estar hospedado em uma casa de comércio. Olha! se quiseres mudar-te lá para a república. Sempre é outra cousa morar com rapazes!"

Coluna 06 - Final: “- Dá cá daí uns cinqüenta ou sessenta. Depois te os pagarei. Pois não! disse Amâncio, passando-Ihe três notas de vinte mil réis".

\subsubsection{Técnicas básicas do padrão narrativo do romance-seriado}

Esta seqüência apresenta a técnica da narrativa folhetinesca com a "estrutura sinusoidal da intriga: técnica de contar a história provocando um fluxo alterado de tensão e distensão por meio da organização dos elementos da narrativa nas seqüências". Este modo de conduzir a história provoca expectativa por parte do leitor, que nunca sabe o que virá na próxima seqüência: não se sabia se seria retomada a conversa entre Amâncio e Coqueiro ou se a briga mereceria destaque especial. Quando a confusão foi focalizada, percebemos que além dos "cortes com ganchos nos finais de segmentos", Aluísio também fazia uso da inserção de episódios extradiegéticos para aumentar o suspense.

Na coluna 06 há um "lance teatral" que marca a representação nada civilizada de Paiva, que começa a "derramar o resto das garrafas no açucareiro, a emporcalhar o damasco da cortina e a cuspir dentro das chávenas". Além disso: "meteu no bolso um paliteiro e duas colheres".

O final desta seqüência coincide com o final do almoço no qual Amâncio conhece Simões e Coqueiro, ao mesmo em que tempo retoma o acordo estabelecido entre os dois maranhenses, registrado na coluna 03 do dia 14 de março, no qual Amâncio dispõe-se a ajudar Paiva:

- Esqueceste aquilo de que falamos?... observou ele ao outro em viagem. Amâncio já não se lembrava.

Paiva respondeu, fazendo um sinal com os dedos.

- Ah! Quanto queres?

- Dá cá daí uns cinqüenta ou sessenta. Depois te os pagarei.

- Pois não! disse Amâncio, passando-lhe três notas de vinte mil réis". 
Tanto no romance-seriado quanto no livro, o "didatismo narrativo" retoma episódios interrompidos por outras ações e torna o final um tanto quanto inconsistente: Amâncio entrega a Paiva o valor solicitado, sem contestar ou fixar uma data para o pagamento. Como os dois estão se dirigindo à república onde Paiva estava hospedado, nada justifica o fato deste ter solicitado o dinheiro naquele momento, a não ser o fato de Amâncio estar bêbado e, por isso, atenderia ao pedido facilmente.

\subsubsection{Quinta seqüência: 17 de março (11)}

\subsubsection{Principais ações desta seqüência}

Coluna 01 - Início: "Amâncio chegou à república muito enfermado, quase que não dava conta dos quatro lances de escada, que era necessário vencer para se alcançar a sala".

Coluna 02 - "- Eu quero vomitar! Exclamou Amâncio, apressado pela agonia. Mas não teve tempo senão para erguer a cabeça".

Coluna 03 - "- Olha! Disse ao Paiva - creio que está ai sobre a mesa, por detrás do Comte. É um frasquinho quadrado, com rolha de vidro".

Coluna 04 - "Por todo o quarto havia um ar profundamente de desmazelo e boemia".

Coluna 05 - "Por toda a parte, pontas esmagadas de cigarro e cuspalhadas secas. No meio do chão, com o gargalo decepado, jazia uma garrafa".

Coluna 06 - Final: "E o homem do lixo entrava e saia familiarmente, com o seu gigo às costas. Um relógio da vizinhança bateu 6 horas".

\subsubsection{Técnicas básicas do padrão narrativo do romance-seriado}

O início apresenta um novo espaço fechado, que é mencionado do início ao final desta seqüência.

Nesta seqüência, são esmiuçadas as conseqüências da bebida sobre o corpo 
fraco de Amâncio, que é apresentado em delírio, em meio a uma crise nervosa, numa "contraposição entre a fraqueza e o vício". No livro, esse aspecto é menos enfático.

Outro aspecto importante é a apresentação de cenas características da narrativa Naturalista, que pode ser evidenciada na sujeira do quarto de Paiva, onde Amâncio havia vomitado, e que, no dia seguinte, ele via secar no chão, azedando o ambiente, misturando-se ao cheiro da louça cheia de gordura sobre a pia. Apesar de sentir-se bem entre os boêmios, nesse momento, sentiu-se mal no meio de tanta sujeira e ela o espantava.

\subsection{Capítulo IV - dois segmentos}

\subsubsection{Primeira segunda seqüência: 20 de março (12)}

\subsubsection{Principais ações desta seqüência}

Coluna 01 - Início: "Amâncio reparou que estava com muita sede, mas não descobriu a talha d'água. Afinal encontrou-a em um sótão, que ficava ao lado do quarto, e onde só agachado se podia penetrar".

Coluna 02 - "Amâncio não fez caso, e beijou-a, à força, pela boca e pelos olhos".

Coluna 03 - "- Oh! Ele sentia-se muito farto de ser governado, de ser vigiado a todos os instantes! - Já era tempo de gozar um pouco de liberdade".

Coluna 04 - "Ângela retraía-se, cortava em meio as carícias do filho, como se as recebesse de um amante, em plena ilegalidade do adultério".

Coluna 05 - "- O demoninho era levado! E assim se foi tornando mulherengo, fraldeiro, amigo de saias. A mãe, quando ouvia da varanda as risadas da criadagem, gritava logo por ele".

Coluna 06 - "Algumas [moças] Ihe perguntavam [brincando] se ele as queria para mulher, se queria ser seu noivo. Amâncio respondia que sim, com um arrepio. E elas 
daí a pouco ficavam muito surpreendidas quando o demônio do menino lhes saltava ao colo e principiava a beijar-lhes com sofreguidão o pescoço e os cabelos, metendo-lhes a língua pelos ouvidos".

Final: "[...] De todos os brinquedos, o que Amâncio em pequeno mais gostava [estimava] era o de fazer casa ["fazer casa"] [...]. Uma de suas primas, filha do protetor de Campos, ou alguma menina que estivesse passando o dia com ele, representava de mulher; Amâncio de marido. A menina ficava debaixo da mesa e ele andava por fora a trabalhar ["a ganhar a vida" até que se]; depois recolhia-se a casa também [...]. "Gostava infinitamente dessa brincadeira; mas um belo dia desprendeuse [veio abaixo] o lençol que servia de parede, e Ângela desde então não consentiu que o filho se divertisse a fazer casa" [Entre colchetes estão as principais alterações verificadas no conteúdo do livro].

\subsubsection{Técnicas básicas do padrão narrativo do romance-seriado}

Um pequeno recuo no tempo retoma o dia anterior, quando Amâncio conheceu Coqueiro e Simões. A primeira coluna retoma os gastos excessivos, quando Amâncio conta o dinheiro que trazia consigo, "lamentando mentalmente o que gastara na véspera": oitenta e cinco mil réis com o almoço, 60 mil réis com o empréstimo feito a Paiva. Depois disso, "há a dilatação dos elementos narrativos de tempo, de lugar e de ação dos personagens no desenvolvimento da intriga do romance".

Há uma abundância de episódios, nesta seqüência, para explicar, com a técnica de "conduzir para trás", como se desenvolveu o lado libertino de Amâncio. Quando o estudante deixa o quarto de Paiva, depara-se com uma jovem que estava subindo as escadas, então agarra a jovem pela cintura, beijando-a à força. Esse assédio caracteriza-se como uma repetição do hábito que ele tinha desde muito pequeno, quando, ao perceber uma oportunidade, saltava ao colo das moças, beijando-lhes e "metendo-Ihes a língua pelos ouvidos" (coluna 06).

Na terceira coluna, enquanto toma café, Amâncio reflete sobre a necessidade de ser livre. É então que o personagem recorda-se "do seu pobre passado de submissão e disciplina": Antes de entrar na escola, não podia transpor sozinho a porta da rua ou do quintal; depois, caiu nas garras do professor Pires; na época em 
que estava no Lyceu [onde ingressou com quatorze anos], era vigiado pelo pai, pelos tios e tias; só na fazenda da avó, durante os meses de férias, que gozava de alguma liberdade.

Como sofria muito com as privações e castigos, encontrava na mãe o verdadeiro amor, por isso a amava verdadeiramente, como um Édipo, conforme pode ser constatado na coluna quatro, deste segmento. Na cinco, são relatadas as peripécias em momentos de luxúria, quando Amâncio assediava as empregadas, movido pelo clima tropical: "Isso se dava quase sempre no intervalo das aulas, pelo alto do dia, quando o calor quebrava o corpo e punha nos sentidos uma pasmaceira voluptuosa". Esta seqüência é encerrada com os pequenos romances que Amâncio tinha com as primas e meninas que passavam o dia com ele, quando brincavam de fazer casa.

\subsubsection{Segunda seqüência: 21 de março (13)}

\subsubsection{Principais ações desta seqüência}

Coluna 01 - "Muitos anos depois, já no Lyceu [aos quinze anos], sentiu-se incomodado por um padecimento estranho. Não disse nada à família e procurou um homem que havia na província com grande habilidade para curar todas as moléstias, até mesmo as produzidas pelo mau-olhado e pelo feitiço".

Coluna 02 - "E, de repente, sem dar por isso, achou-se a fazer conjeturas sobre o amor de Hortênsia".

Coluna 03 - "E seu espírito enfermo, começava a despi-la, peça por peça, até deixála completamente nua".

Coluna 04 - "As oito horas, quando entrou em casa, tinha já a resolução de não ficar ali nem mais um dia. Era fazer as malas e bater quanto antes a bela plumagem!"

Coluna 05 - "Amâncio não sabia o que deliberar. O Coqueiro, com a sua figura de tísico, o seu rosto chupado e quase verde, os seus olhos pequenos e penetrantes, de uma mobilidade de olho de pássaro, com a sua boca fria, deslabiada, o seu nariz 
agudo, o seu todo seco, egoísta, desenganado da vida, não era das coisas que mais o atraíssem; mas quem lábia lá!? Bem podia ser que estivesse ali o que ele procurava - um cômodo limpo, confortável, um pouquinho de luxo e plena liberdade!... [Talvez aceitasse o convite]".

Coluna 06 - "Corte sistemático": "E tudo ali em casa de Campos o aborrecia! [...] E quando passou pela porta da rua teve ímpetos de esbordoar o caixeiro, que estava esse dia de plantão".

\subsubsection{Técnicas básicas do padrão narrativo do romance-seriado}

O início deste segmento retoma a época em que Amâncio estava no Lyceu (no livro não consta essa informação e, no lugar dela, há o dado de que, nessa época, ele tinha 15 anos). O leitor do romance-seriado precisaria retomar a leitura de segmentos anteriores, para contatar que Amâncio havia ingressado no Lyceu aos com 14 anos, no entanto, não chegaria à idade exata de 15 anos, fixada no livro.

Mesmo depois de ter sido curado da moléstia, mais tarde, Amâncio caiu "de cama, prostrado por novo carregamento, que o ia varrendo ao cemitério". A técnica composicional da narrativa folhetinesca pode ser percebida pelo "didatismo narrativo", pois "esses foram os três anos de sezões a que se referia [na primeira seqüência], quando encontrou-se com o Campos pela primeira vez [...]". Com isso, o tempo narrativo retoma a ordem cronológica, no espaço do Rio de Janeiro, durante o café tomado depois de Amâncio sair da república de Paiva. Na medida em que começa a pensar em Hortênsia, Amâncio não consegue controlar o fluxo de seus pensamentos, por isso se perdia em "Cálculos infames" (coluna 03).

Como apenas Hortênsia prendia Amâncio à casa de Campos, refletiu muito e, quando chegou à conclusão de que ela era apenas "uma pobre mulher honesta, incapaz de cometer uma asneira", o maranhense decidiu deixar a casa do comerciante.

Quando chega à casa de Campos, Amâncio depara-se com um acontecimento inesperado: Coqueiro havia enviado uma carta, na qual antecipa para aquele dia o convite para Amâncio ir visitá-lo, o que provoca "mudanças inesperadas nos episódios".

A técnica folhetinesca de inserir "vilões da história com traços grosseiros e 
satânicos" já foi utilizada para assinalar o antagonista na seqüência publicada no dia 15 de março, quando Amâncio almoçou com Coqueiro, e é retomada neste segmento, coluna 05 , apresentando mais detalhes à caracterização do personagem.

\subsection{Capítulo V - um segmento e recortes de um possível segmento extraviado}

\subsubsection{Primeira seqüência: 22 de março (14)}

\subsubsection{Principais ações desta seqüência}

Coluna 01 - Início: "João Coqueiro era fluminense da gema. Nascera na Rua do Parto em uma das casas de seus pais, nos belos tempos da prosperidade".

Coluna 02 - "O casamento foi para ele [pai de Coqueiro] uma tábua de salvação. A mulher adorava-o [...]; mas, Lourenço depois de casado, principiou a desgostá-la [...]. Tiveram o primeiro filho - Juca. Criancinha feia, sem sangue, cheia de asma. Até aos cinco anos parecia idiota; passava os dias a babar-se debaixo da mesa de jantar, ao pé do moleque que tomava conta dele".

Coluna 03 - “- Ele pode machucar-se, Lourenço, cair! Observava a esposa timidamente. - Pois deixa-o cair! deixa-o machucar-se! Quanto mais trambolhões levar em pequeno, melhor depois se agüentará depois nas pernas! - Mas ele é tão fraquito, coitadinho!"

Coluna 04 - "À mesa não consentia que o filho [João Coqueiro] se sentasse senão ao seu lado. Obrigava-o a comer bifes, dava-Ihe vinho sem água [...]. Janjão chorava mais. - Isso é que o há de pôr pra diante! Gritou [No livro: Berrou] o pai encolerizando-se".

Coluna 05 - "Quando Juca principiou a crescer, o pai levava-o a passeio, dava-Ihe charutos, obrigava-o a tomar cerveja nos cafés [...]. Juca só com a vista do mar ou a presença de um revólver desatava a soluçar e a berrar pela mãe" [...]. E com muita sutileza, comprou para o filho uma bela pistolinha de brinquedo, que estalava 
fulminante".

Coluna 06 - "A mãe acabava de dava-lhe uma irmãzinha, que se ficou chamando Amélia, e o maior encanto do rapaz [livro: menino] era tomar conta do caixãozinho em que ela estava envolvida em panos, a enxotar as moscas que tentassem pousar na cabeça da pequenita".

Final: "Ele queria lá filhos devotos! Era só o que Ihe faltava! Era só! Aquele menino parecia o seu castigo! Parecia a sua maldição!"

\subsubsection{Técnicas básicas do padrão narrativo do romance-seriado}

Este segmento tem como primeira marca a técnica de "conduzir para trás", repetindo o que Genette (1995) caracteriza de analepse. Esse recurso já foi utilizado para fazer uma retrospectiva do passado do protagonista e, agora, também é empregado para acrescentar informações sobre a infância do antagonista, a fim de explicar de que modo o meio pode ter influenciado sua vida, transformando-o em criminoso e guardião da irmã. Sua mãe era rica, o pai vagabundo e o filho [Coqueiro] tolo.

Assim como Amâncio, Coqueiro também sofria muito com o modo de educar do pai e estes eram os vilões de seus primeiros anos de vida. No livro foi acrescentada a informação de que o pai o obrigava a beber conhaque, além de cerveja e vinho mencionados na romance-seriado. O pai fazia questão que João aprendesse a atirar [“- Tu ao menos ficarás sabendo dar um tiro!"] e isso pode ter sido um dos fatores para que, posteriormente, viesse a tornar-se assassino de Amâncio.

Apesar de todas as colunas deste segmento estarem voltadas exclusivamente para Coqueiro, sua voz não é notada e, no lugar dela, o personagem se expressa pelo choro, berros e tremores. A partir da terceira coluna, há "abundância de diálogos", que revelam o discurso machista do pai e a timidez da mãe, cujo nome não é revelado.

Como Coqueiro era frágil e sensível, a mãe o consolava, da mesma forma que Ângela confortava Amâncio. Outra semelhança entre a infância dos dois personagens é a de que Amâncio gostava de brincar de fazer casa, Coqueiro ficava 
entretido a vestir os seus bonecos ou a fazer de cozinheiro. Os dois viam nos pais verdadeiros carrascos e nas mães o refúgio, o colo que os protegia dos carrascos que tentavam fazê-los machos e não homens de caráter.

Outra técnica narrativa é a "presença de epíteto para caracterizar o personagem" João Coqueiro. Enquanto a mãe o chama de Juca e Juquinha, o narrador utiliza o epíteto Juca e o pai não admite que o chamem senão de João, o nome dado em homenagem ao avô, um fidalgo bastardo. No livro, o epíteto utilizado é Janjão.

A descrição de Lourenço, pai de Coqueiro, é feita com muito humor: ele possuía os bigodes mais compridos do Rio de Janeiro dessa época; "do que fora e do que possuíra, apenas Ihe restava, além do bigode, o hábito de não fazer coisa alguma"; nos melhores grupos, citava-se, entretanto, o seu ar distinto de fidalgo, mas não passava de sobrinho bastardo de um conde português.

\subsubsection{Conteúdo retirado da versão em livro e não localizado no romance- seriado}

\subsubsection{Principais ações deste recorte}

\subsection{Uma antítese de Amâncio}

Contrariando a infância débil apresentada no segmento acima, Coqueiro destacava-se no internato de Pedro II pelo fato de ser muito estudioso, paciente, dedicado aos estudos e respeitava a autoridade dos professores. Além disso: "Tinham-no em boa estima pelo seu espírito católico, pela docilidade de seu gênio e pelo irrepreensível de sua conduta". Por isso, "ninguém the ouvia palavra mais áspera ou gesto menos conveniente, e às vezes entrava pela hora do recreio grudado aos livros sem os querer deixar".

Apesar de o pai ter feito de tudo para mudar seu filho, agora tinha muito orgulho dele, chegando a profetizar que "ali estivesse um sábio" [...]. Como mérito de tanta dedicação, Juca tirou distinção nos primeiros exames. O pai ofereceu uma festa modesta, diferente daquela oferecida pelo Vasconcelos ao filho Amâncio, 
porque a doença de Lourenço e sua falta de vontade para o trabalho estavam consumindo a herança da mulher.

\subsection{A redenção do pai}

A doença do pai de João Coqueiro deformara seu aspecto viril: "Estava acabado; crescera-Ihe o ventre, o nariz tomara uma vermelhidão gordurosa, o cabelo encanecera totalmente, a cabeça despira-se, a pele do rosto fizera-se opada e suja".

Como conseqüência, suas atitudes também mudaram, fazendo-o tentar resignar-se do que fizera durante toda a sua vida. Ao ver-se doente, ia "à noite pelas igrejas [...]. Ajoelhava-se a um canto da nave, em cima das pedras, e aí permanecia longamente, a ouvir os sons lamentosos do órgão, com o rosto descansado sobre as mãos que se cruzavam no castão da bengala". Seu padecimento era tanto que "às vezes chorava".

Dia após dia, definhava: "Seu estômago irritado já não queria os alimentos [...]. Não se Ihe podia suportar o hálito". Mas a notícia de que a sua especulação falhara que o deixou paralisado, levando-o à morte no dia seguinte. A técnica folhetinesca do "acaso como ponto de convergência entre alguns acontecimentos da narração" redireciona a vida de João Coqueiro.

\subsection{A decadência da família Coqueiro e a casa de pensão}

Como foi preciso vender o melhor dos dois prédios que restavam, para saldar as dívidas do defunto, a família Coqueiro ficou pobre. A partir disso, a viúva passou a "tomar encomendas de costura e de engomagem". Como a renda obtida nessas atividades não era suficiente, a viúva de Lourenço decidiu arranjar fregueses para o almoço e admitir hóspedes em sua residência: "Dentro de pouco tempo, o sobrado da viúva de Lourenço era a mais estimada e popular casa de pensão do Rio de Janeiro". E, desse modo, "o órfão prosseguiu nas suas aulas".

Foi na casa de pensão que "Janjão se fez homem. Aí o viram bacharelar-se e aí se matriculou na Escola Central". Desde a morte do pai, Amélia respeitava o irmão como a um pai. Como a casa de pensão era uma atividade necessária para o sustento da família, ela cresceu "no meio da egoística indiferença de vários hóspedes [...]", o que não a impediu de aprender a ler, a escrever e a tocar piano. 


\subsection{A morte da mãe e o fechamento da casa de pensão}

A exploração da "temática de aspectos da vida miserável", característica da técnica folhetinesca, pode ser aplicada ao novo acaso que muda a vida da família Lourenço: "Um novo desastre veio, porém, alterar todos esses planos: a viúva de Lourenço, depois de dois meses de cama, sucumbiu a uma pneumonia". Nessa época:

João Coqueiro estava então no segundo ano da Politécnica; Amélia a fazerse mulher por um daqueles dias; parentes - não os tinham... capitais - ainda menos...Como pois sustentar a casa de pensão? ...Oh! Era preciso despedir os hóspedes, alugar o prédio, abandonar estudos e obter um emprego.

\subsection{A segunda mãe - gancho para o próximo segmento}

Coqueiro, moço de vinte e seis anos, destacava-se pela inteligência, no entanto, a morte dos pais e a decadência da família obrigaram-no a abandonar os estudos, fechar a casa de pensão e a trabalhar na estrada de ferro de Pedro II, para conseguir pagar suas despesas e as de sua irmã Amélia. Mudaram-se para a casa de pensão "de uma francesa, muito antiga no Brasil e que durante longo tempo se mostrou amiga íntima da defunta". Ela se chamava Mme. Brizard: "Estava ainda bem disposta, apesar da idade [aproximadamente cinqüenta anos]. Gorda, mas elegante e com uns vestígios assaz pronunciados de antigas formosuras. Tinha os olhos azuis e os cabelos pretos, no tipo peculiar ao meio-dia da França. Carne opulenta e quadril vigoroso".

A francesa foi se tornando "muito caída para o romantismo" na medida em que envelhecia, às vezes, deparava-se a ver apreciar a noite de luar; "dava-se à leitura prolongada de poetas tristes; fazia-se mais infeliz do que era de fato, e contava a todos a sua história - Um romance!"

A técnica de "conduzir para trás" para acrescentar a informação de que: "Aos quinze anos saíra da família pelo braço de um diplomata russo, que a idolatrava: - ia casada", apesar de sofrer muitos assédios, "conservou-se pura e fiel ao marido". Ainda não tinha filhos quando, cinco anos depois, enviuvou.

Depois de viúva, voltou a morar com a família e, pouco depois, apareceu-lhe o Mr. Brizard, "homem de talento, político e escritor, grande republicano. A subida de 
Luís Felipe ao trono atirou com ele ao Brasil". Essa segunda união deu-lhes três filhos: duas mulheres e um homem.

Como não sabemos o nome de Mme. Brizard senão a partir do sobrenome do segundo marido ao da referência à nacionalidade francesa, pressupomos que sua importância dentro do romance está associada ao foto de seu marido francês ter sido hoteleiro no Brasil, sendo que foi com ele que a madame aprendeu como administrar uma casa de pensão, depois que ficou viúva pela segunda vez e precisou sustentar os três filhos:

A filha mais velha representava a glória da família: unira-se a um ministro plenipotenciário; a outra [Nini, personagem de Casa de Pensão], coitada, não casou mal, porém com a morte do marido, e de um filhinho que lhe ficara, tornou-se muito nervosa, histérica, e até, meio pateta; agora vivia e mais o irmão em companhia da mãe.

De repente, ingressaram à sua casa de pensão dois hóspedes que dariam um novo rumo à sua vida: "a proposta de João Coqueiro pareceu vantajosa a Mme. Brizard. - Ele que trouxesse a irmã a bela Amelita, e tudo se arranjaria pelo melhor".

\subsection{Capítulo VI - um segmento}

\subsubsection{Primeira seqüência: 24 de março (15)}

\subsubsection{Principais ações desta seqüência}

Coluna 01 - Início: "Mme. Interessava-se pelos dois hóspedes, principalmente pelo Coqueirinho como ela tratava o rapaz [No livro: como Ihe chamavam em família]".

Coluna 02 - "Lamartine lá estava no seu quarto, sobre o velador, encadernado com esmero. Mas também apreciava alguns escritores brasileiros [no livro: não desdenhava os poetas brasileiros e lia Camões]". 
Coluna 03 - "Uma tarde, acharam-se os dois, um defronte do outro, assentados sozinhos na varanda da sala de jantar, que dava para um lugar plantado de bananeiras. O sol descia lentamente no horizonte por uma escadaria de fogo. As cigarras estridulavam no fundo das matas [chácara]; a noite ia emanando".

Coluna 04 - "- Ela estava no caso de fazê-lo feliz, porque o amava! Oh! Se o amava! [...] Queria casar-se, porque entendia que isso era necessário à felicidade de Coqueiro".

Coluna 05 - "- Casados, poderiam ressuscitariam a antiga casa de pensão [...] Coqueiro abandonava o emprego e atirava-se de novo aos estudos".

Coluna 06 - "[...] à Amélia Um bom casamento! - um casamentão!” Mme. Brizard [Ah! Ela, a francesa], sabia [perfeitamente] como tudo isso se arranjava [no Brasil]".

Final: "Meteram mãos à obra. Coqueiro deixou o emprego, tratou [contratou] um empreiteiro para restaurar o seu velho prédio da Rua do Resende, e a casa de pensão de Mme. Brizard, como teimosamente continuaram a tratar a mulher, surgiu ameaçadora, escancarando para a população a sua boca de monstro".

\subsubsection{Técnicas básicas do padrão narrativo do romance-seriado}

Nas quatro primeiras colunas, há ênfase especial à aproximação de Coqueiro e Mme. Brizard. A "situação social insatisfatória" de Coqueiro abrigava-o a aceitar a união com a francesa. Como fruto dessa aliança de interesses, a quinta coluna revela que: “- Casados, poderiam ressuscitariam a antiga casa de pensão [...]". E assim nasce renasce a casa de pensão.

O final deste segmento apresenta a casa de pensão personificada, como um monstro, cuja boca assustava a população. No livro, sua localização é especificada ao Rio de Janeiro. A partir desse momento, um novo personagem é adicionado à narrativa a casa de pensão, ao mesmo tempo em que se caracteriza como espaço fechado, que aprisiona os seres e favorece a disseminação dos vícios.

A analogia feita à casa de pensão se remete à técnica narrativa da "verossimilhança que nunca escorrega para o irracional" [...] porque há "uma explicação real para a verossimilhança dos fatos". A mesma casa de pensão que 
assustava a população, também ressuscitava o cenário da Questão Capistrano, por isso, a casa de pensão surgia ameaçadora, "escancarando para a população a sua boca de monstro".

Uma particularidade especial distingue a organização estrutural deste segmento nas duas versões de Casa de Pensão. Enquanto o romance-seriado insere o número VI, para defini-lo como parte inicial do sexto capítulo, o livro coloca esse texto no meio de outras informações, sem haver parágrafo em seu início. Por outro lado, não tivemos acesso à seqüência que poderia ter registrado o conteúdo que corresponde ao sexto capítulo do livro.

\subsubsection{Conteúdo retirado da versão em livro e não localizado no romance- seriado}

\subsubsection{Apresentação dos espaços e moradores da casa de pensão}

Amâncio chegou ao Rio de Janeiro três anos depois da união de Coqueiro e Mme. Brizard, bem como da reabertura da casa de pensão. Nessa época, a casa da francesa estava no seu apogeu: "de todos os lados choviam hóspedes, entre os quais se notavam pessoas de importância", verdadeiras celebridades.

A proprietária era admirada pela beleza. Apesar dos cinqüenta anos, ela tinha o pescoço e os ombros admiráveis e: "Quem dera a muitas novas um colo daqueles!". A cunhada, por sua vez, é apresentada pelo diminutivo afetivo e pelos dotes culinários: "No Rio de Janeiro ninguém fazia espetadas de camarão tão saborosas como as da simpática irmãzinha do João Coqueiro, a Amelita".

Depois da apresentação de Amélia e sua cunhada, este recorte detém-se à apresentação do interior da casa de pensão, estruturada em dois andares, com uma boa chácara no fundo. O salão de visitas era no primeiro.

Há um aspecto que retoma a nota Antes de principiar - lançada na véspera da publicação da primeira seqüência do romance-seriado -, quando o escritor antecipa que por melhor que seja o hóspede: "Os velhos móveis não lhe falam nada", apesar de representarem muitos para seus proprietários. Como modo de caracterizar a preocupação com os detalhes, a descrição da mobília da casa de 
pensão é feita de modo minucioso, o que também serve para caracterizar o cenário que merecerá grande destaque para o desenvolvimento das principais ações narrativas seguintes.

Depois da apresentação da casa de pensão, há o emprego da técnica de "conduzir para trás" para narrar o momento em que João Coqueiro sai do Hotel dos Príncipes, onde havia conhecido Amâncio. Ao sair do estabelecimento, estava "preocupado; o Simões, que caminhava à sua esquerda um pouco sacudido pelos vinhos, em vão tentou, repetidas vezes, puxá-lo à palestra; o outro respondia apenas por monossílabos e, na primeira esquina, despediu-se e correu logo para casa". Com o plano já tramado, ao "chegar foi direto à mulher, dizendo-lhe em voz baixa, antes de mais nada: Olha cá, Loló”... Mme. Brizard largou o que tinha entre as mãos e seguiu-o atentamente até o quarto, onde o marido lhe diz em segredo:

Sabes? Disse ele, sem transição, assentando-se ao rebordo da cama. - É preciso arranjarmos cômodo para um rapaz que há de vir por aí domingo. Um rapaz! Mas tu sabes perfeitamente que os quartos acham-se todos ocupados. Se tivesses prevenido... $\circ \mathrm{n}^{\circ} 2$ ainda ontem estava vazio...Mas quem é?

Há de se arranjar, seja lá como for! Disse o Coqueiro.

Mas quem é?...insistiu Mme. Brizard.

Coqueiro justifica que o rapaz: "É um achado precioso! Ainda não há dois meses que chegou do Norte, anda às apalpadelas! Estivemos a conversar por muito tempo: - é filho único e tem a herdar uma fortuna! Ah! Não imaginas: só pela morte da avó, que é muito velha, creio que a coisa vai para além de quatrocentos contos!..... Enquanto isso:

Mme. Brizard escutava, sem despregar os olhos de um ponto, os pés cruzados e com uma das mãos apoiando-se no espaldar da cama.

Ora , continuou o outro gravemente. - Nós temos de pensar no futuro de Amelinha... ela entrou já nos vinte e três !... se não abrirmos os olhos... adeus casamento!

Mas daí... perguntou a mulher, fugindo a participar da confiança que o marido revelava naquele plano.

Daí - é que tenho cá um palpite! explicou ele. - Não conheces o Amâncio!... A gente leva-o para onde quiser!... Um simplório, mas o que se pode chamar um simplório!

Mme. Brizard fez um gesto de dúvida.

Afianço-te, volveu Coqueiro, - que, se o metermos em casa e se conduzirmos o negócio com um certo jeito, não lhe dou três meses de solteiro! 
Apesar de não expressar cumplicidade nesse momento, Mme. Brizard ajudaria o marido nesse plano. A partir de então, entra em vigor a estratégia de arranjar um casamento para Amélia e resolver suas "situações sociais insatisfatórias".

\subsection{Capítulo VII - oito segmentos}

Neste capítulo, podemos observar, também, a ampliação do espaço e a inserção de novos personagens à narrativa. Amâncio vai conhecer a casa de Coqueiro e é recebido com um jantar de boas-vindas, quando, então, é apresentado aos demais moradores, no entanto, não há a análise psicológica dos mesmos. Lúcia, por exemplo, foi descrita em seu aspecto físico e alguns "diálogos" com o protagonista the atribuem traços de intelectualidade, o que se assemelha ao conteúdo em livro. A inserção desses novos personagens, sobretudo Lúcia e Amélia, assume um caráter importantíssimo para o desenvolvimento da intriga.

\subsubsection{Primeira seqüência: 27 de março (16)}

As principais ações desta seqüência são decorrentes da tentativa de Mme. Brizard tentar convencer a cunhada de que era necessário aderir ao plano traçado pelo irmão, o que se dá no início desta seqüência. Amélia, por sua vez, tenta contrariar as expectativas dos dois e demonstra não querer ser guiada pelo irmão, no entanto, essa reação da personagem não é preservada na publicação em livro. Por outro lado, alguns trechos inseridos no livro ressaltam o desespero que a jovem tinha em casar-se, porque "não queria ficar solteirona" e, além disso, o casamento significava uma possibilidade de adquirir uma boa posição social.

Como o respeito pelo irmão faz com que Amélia aceite participar do plano, a partir desse ponto, o fio condutor de Casa de Pensão explora a temática dos "aspectos da vida criminosa e miserável e da vida urbana selvagem; maniqueísmo na contraposição entre o bem e o mal: o herói e a sociedade, a felicidade e a desgraça, amor puro ou selvagem, ódio unilateral, a virtude, os vícios e outros; o 
poder dado àquele que é mais forte, mais hábil, mais audaz" ${ }^{13}$. Essas técnicas narrativas remetem-se à armadilha criada por Coqueiro e às possíveis conseqüências que isso teria no desenvolvimento da intriga, pois, apesar de os leitores do romance-seriado não terem acesso aos vinte e dois capítulos do romance, as intenções de Coqueiro e a apresentação da casa de pensão estabelecem relação direta com Alexandre Pereira e com os motivos que resultaram na Questão Capistrano.

Todas as informações destacadas a seguir foram suprimidas ou alteradas no livro, o que demonstra a tentativa de Aluísio abstrair termos característicos da linguagem oral, uma vez que no romance-seriado:

\begin{abstract}
Amélia concentrou-se e pouco depois prometeu que havia de fazer o que pudesse para agradar a Amâncio. Aquela vida de solteira ia com efeito a enfastiando de dia para dia.

Já não estava com idade para ser governada como uma criança. Não sabia o que diabo queria dizer uma mulher como ela ser diariamente tratada com pieguices e com as insuportáveis cautelas com que em geral tratam as meninas. - Não estava para isso! Com a educação que lhe coube e com o meio em que se desenvolveu sabia perfeitamente o que era pão e o que era queijo; por conseguinte as reservas de Mme. Brizard e as discrições do irmão, irritavam-na [livro: tomava para com ela, faziam-na sorrir].
\end{abstract}

$\mathrm{Na}$ continuidade deste segmento, as reflexões de Amélia continuam a apresentar marcas da oralidade: "Se precisavam dela, que se explicassem por uma vez, e se não precisassem que a deixassem em paz com todos os diabos!". Na primeira citação, é utilizado o termo "diabo"; no final da segunda, há esta expressão de revolta: com todos os diabos! - em ambos os casos, esse substantivo foi excluído da versão em livro, embora tenha sido preservado em outras partes do romance.

O conteúdo desta seqüência focaliza a tentativa de Mme. Brizard convencer Amélia a aderir ao plano traçado por Coqueiro. A interrupção feita antes da chegada

13 Conforme nota explicativa de Ribeiro (1996, p.49), ressalta-se que: "adotaram-se no desenvolvimento da análise subseqüente dos romances as noções de Pavel Medvedev/Mikhail Bakthin e de luri Lotman sobre o conceito de tema. Os dois primeiros (1991, p. 132) expõem que o tema da obra 'é o conjunto da enunciação como um ato sócio-histórico definido' e, em conseqüência disso, ele é 'inseparável da situação total da enunciação no mesmo grau em que é inseparável dos elementos lingüísticos'. É importante lembrar que em Pavel Medvedev/Mikhail Bakthin (p. 120) toda enunciação concreta é um 'ato social...', entendem que ao mesmo tempo que ela tem um material individual complexo (articulatório, fonético, etc.), ela é parte de uma realidade social. Advertem ( $p$. 133) que a língua e as suas formas têm um papel fundamental no processo de refração da existência na consciência; no entanto, que a forma da enunciação, não a da língua, que desempenha o mais importante papel na compreensão e na tomada de consciência da realidade". 
de Amâncio à casa de pensão estabelece um gancho com o próximo segmento. Além disso, o corte instaura um grande suspense, pois não foi apresentada nenhuma informação sobre como seria o encontro de Amâncio com a família de Coqueiro e como Amélia agiria ao vê-lo.

\subsubsection{Segunda seqüência: 28 de março (17)}

O gancho inserido no início deste segmento retoma o momento em que Amâncio se aproxima da casa de pensão: "Coqueiro levantou-se prontamente do lugar onde estava e atirou-se para o corredor, com o alvoroço expansivo e alegre de quem recebe um velho amigo, depois de longa ausência".

O autor retoma a descrição feita na primeira seqüência do romance-seriado, para destacar que, agora, o maranhense não tinha "o mesmo tipo mal ajeitado com que se apresentara ao Campos", pois teve o cuidado de ir à casa de Coqueiro com um terno de casimira, que havia comprado naquela mesma manhã, pouco antes de conhecer a família do novo colega.

É com muito esforço que Amâncio tenta "armar bem a frase e fazendo esforço para se mostrar homem de boa educação". É Mme. Brizard que conduz a primeira conversa e quase que não deixa o convidado falar, a não ser quando ela lhe faz alguma pergunta. De modo acentuado, este segmento apresenta "abundância de diálogos", abstraídos, parcialmente, da versão em livro, o que confere ao texto a mudança de ritmo.

No final desta seqüência, Amâncio apresenta seu ponto de vista sobre as travessuras de Cezar, filho mais novo de Mme. Brizard, quando: "Cezar soltou uma risada, e Amâncio apressou-se a declarar que detestava as crianças que não fossem travessas. Ele não queria meninos com propósito de velhos, em velhos com modos de criança". Essa declaração, que sofreu modificações significativas na versão em livro, faz referência ao tipo de liberdade que Amâncio gostaria de ter tido, se não fosse o controle excessivo exercido sobre ele. 


\subsubsection{Terceira seqüência: 29 de março (18)}

Em continuidade à ação descrita na seqüência anterior, há um feito quando: "O moleque aproxima-se com uma bandeja na mão, cheia de copos". Depois disso, a narrativa passa a focar o encanto que Amélia exerce sobre Amâncio e, sem saber que estava perto da isca da armadilha criada por Coqueiro, Amâncio vê-se encantado por Amélia desde o primeiro momento que a observa: "Amâncio considerou intimamente que a achava deliciosa - um mimo!"

Por mais que tentasse prestar muita atenção ao que Ihe diziam os outros, "sua imaginação libertava-se à força e ia cair de novo aos pés da insinuante rapariga, procurando subir e enroscar-se por ela, ao modo do tênue vapor do incenso, quando vai trepando enrolando uma coluna de mármore" ( $3^{a}$ coluna).

$\mathrm{Na}$ versão em livro, foram excluídas as informações destacadas e que se referem ao fato de que "instintos mal-educados de Amâncio latejavam, resolviam-seIhe dentro, formigando num assanhamento crescente" (4 a coluna). Nesta descrição, surge um paradoxo entre o que o protagonista queria parecer e o que realmente era, quando se esforçava para "se mostrar homem de boa educação", conforme ressaltado na seqüência anterior. Então, são delineados alguns dos inúmeros defeitos atribuídos ao protagonista, retomando a segunda seqüência do romanceseriado, na qual consta que: "Amâncio dominava-se, fazia-se sério por medo de apanhar". Por isso, tornou-se reservado e fingido".

Amâncio e Amélia trocam poucas palavras e logo Coqueiro convida o novo amigo a conhecer a casa. Excluído da versão em livro, um episódio sugere uma contraposição entre a liberdade e a prisão, quando Coqueiro, apontando para uma das saídas do terreno, comenta que - "isto é para quando se quiser desfrutar deste outro lado, explicou o Coqueiro. O terraço dava com efeito para uma rua, que passava no fundo da casa" ( $5^{a}$. coluna).

O final desta seqüência ocorre quando Coqueiro mostra a despensa a Amâncio, com a finalidade de ressaltar que ali consumiam "Tudo de primeira, heim?! dizia ele com entonações mercantis, a passar ao colega um punhado de feijões. - É exato! Resmungava este, sem ver", porque, certamente, seu pensamento ainda estava ligado às impressões que Amélia Ihe causara. 
1.7.4 Quarta seqüência: 31 de março (19)

Duas tarjas pretas dificultam a leitura das colunas quatro e cinco, deste segmento. A primeira coluna estabelece continuidade à última do segmento anterior, quando Coqueiro começa a mostrar os quartos dos hóspedes. Quando passam pelas portas, o proprietário também descreve um pouco dos moradores, com a finalidade de mostrar que ali moravam pessoas distintas, o que se estende, também, para as duas colunas seguintes, deixando o maranhense impaciente.

Depois de apresentada toda a casa, a última coluna registra a tentativa de Coqueiro convencer Amâncio das vantagens que teria caso resolvesse hospedar-se ali, pois: "Aqui ficas muito bem! Serás tratado como um filho; em breve terás toda a intimidade com minha família [...]. E, amortecendo a voz, concluiu, com sisudez honesta: Agora, quanto a certas visitas... isso tem paciência...". Para enfatizar essa recomendação, Coqueiro ressalta, cheio de escrúpulos: “- Sim! Sabes que isto é uma casa de família e, para a boa moral...". Amâncio, por sua vez, finge concordar: “- Certamente! E acendeu um cigarro”.

Nesse último parágrafo, podemos verificar a técnica folhetinesca do "corte com gancho". A interrupção, nesse ponto, leva o escritor a estimular o leitor para a continuidade da leitura, estabelecendo uma expectativa em relação à próxima seqüência, pois não sabemos o que Amâncio faria depois de saber que não encontraria ali a liberdade tão ansiada.

\subsubsection{Quinta seqüência: 02 de abril (20)}

Na versão em livro, este segmento corresponde ao início do Capítulo VII.

Contrariando as possíveis expectativas provocadas nos leitores, esta seqüência é iniciada com a apresentação do jantar oferecido a Amâncio, ao qual compareceram apenas três hóspedes "- a Lúcia, o marido e o tal gentleman de nome difícil". A partir de então o foco narrativo é voltado para Lúcia, que se assentou ao lado de Amâncio.

A segunda coluna focaliza o momento em que Amâncio, envolvendo Lúcia "em continente num olhar extenso e observador", descreve a hóspede: "de estatura regular, costas levemente arqueadas, ombros erguidos, como por uma forte impressão de medo: braços descaídos, cintura pouco abaixo dos seios, desenhando 
muito a barriga, que não era pequena". Essa tipificação - feita por intermédio da voz do narrador - revela uma marca característica do estilo de Aluísio Azevedo, que é utilizar vocabulário rebuscado até mesmo para construir descrições grotescas.

Sem perder o foco nas ações ligadas à Lúcia, que futuramente seria amante de Amâncio, a terceira coluna enfatiza o controle que ela exercia sobre o marido, caracterizado como um palerma. Quando se via pressionado: "Ele, porém, não dava resposta, e, quando a mulher insistia a muito nas suas recriminações, fechava os olhos", como se fugisse para dentro de si mesmo.

As três últimas colunas são utilizadas para apresentar Nini e a discussão gerada em torno do seu caso de histerismo. Caracterizada como outra personagem que não tem voz, sua única forma de expressão ocorre por intermédio de crises nervosas, decorrentes do histerismo surgido com a viuvez. Esta seqüência é encerrada com sua chegada à sala de jantar. Esse último evento evidencia a técnica folhetinesca do "corte com gancho" e instaura novo suspense à narrativa.

\subsubsection{Sexta seqüência: 05 de abril (21)}

Este segmento estabelece conexão com o anterior, a partir do seguinte excerto:

Só depois de assentada, Nini desmanchou o ar aflito que fazia, pelo esforço de andar.

- Ah! Respirou ela, quase sem fôlego. E correu os olhos em torno de si, abstratamente, como se despertasse de um desmaio. Ao dar com Amâncio, ficou a tietá-lo, com a insistência que usam as crianças ao encararem alguém pela primeira vez. Depois contraiu ligeiramente os músculos do rosto, desviou a vista dele, vagarosamente, a tomar longos sorvos de ar.

Nini continuava a olhar para Amâncio durante algum tempo, imobilizando o rapaz. Foi apenas depois que Mme. Brizard passou a oferecer a Amâncio os melhores pratos que este desviou a atenção na viúva que embranquecia aos poucos. A terceira coluna cede espaço para uma conversa sobre o Maranhão e à seguinte são acrescentadas as informações de que "os grêmios e jornais literários brotavam ali de toda parte, cada indivíduo era um gramático de pulso", enquanto isso Coqueiro fingia acompanhar Amâncio naquele entusiasmo, "mas ria-se por dentro. O outro parecia-lhe cada vez mais tolo".

As referências feitas ao Maranhão estabelecem um gancho com a pergunta 
feita por Lúcia, que questiona Amâncio se "tinha algumas produções maranhenses, que lhe pudesse emprestar. Amâncio prometeu logo fazer-lhe chegar às mãos o que em casa tivesse de melhor a esse respeito". Fazendo-se conhecedor de literatura, Amâncio sugere que Lúcia leia Entre o Céu e a Terra, de Flávio Renar. O assunto sobre literatura leva-os a citar também o folhetinista Joaquim Serra, Franco Sá, Dias Carneiro e Fagundes Varela.

Apenas a vertente folhetinesca, $4^{a}$ coluna, registra a informação de que "Lúcia já conhecia muito o Serra. Era louca por ele como folhetinista, tanto que fez citações de suas obras. Amâncio não conhecia os folhetins, mas calou-se para fazer acreditar que as conhecia". A dissimulação do protagonista demonstra que o mesmo mantinha-se firme no objetivo de manter as aparências, até mesmo mentindo ou omitindo quando necessário.

Depois disso, Mme. Brizard revela que Coqueiro também escrevia versos, mas este dizia preferir assinar com um pseudônimo. Esse assunto estendeu-se até a última coluna, culminando com a exaltação de Coqueiro, que perdera o controle quando chamava os escritores de pedantes: "Hoje, todos querem ser escritores; sujeitinhos que não sabem ligar duas idéias, ignorantes e viciosos, arrogam-se, da noite para o dia, os foros de literatos! Uma cambada!" Mme. Brizard tenta conter o marido, ao mesmo tempo em que diz no ouvido de Amâncio que "também é só o que Ihe faz sair do sério... a literatura! É falar nisso, e fica assim!"

Nesta seqüência, podemos notar a presença da técnica de construção narrativa da "estética divergente e centrífuga", que tem início com a chegada da histérica Nini, tomando novo rumo com a conversa sobre o Maranhão, depois a respeito dos escritores maranhenses, dos autores brasileiros, dos versos escritos por Coqueiro, sendo encerrado com o descontrole deste último e a tentativa de Mme. Brizard explicar a Amâncio as causas da exaltação do marido. 


\subsubsection{Sétima seqüência: 06 de abril (22)}

O gancho estabelecido com a seqüência anterior ocorre quando Amélia pergunta se Amâncio "também, escrevia... O rapaz disse que sim, sorrindo, desculpando-se com os outros, afiançando que todo o mundo escrevia mais ou menos", esquecendo-se que essa empáfia havia tirado Coqueiro do controle poucos instantes antes e, de repente, a conversa dispersa-se e os grupos passam a falar do preço excessivo dos gêneros alimentícios e de questões sobre higiene, dentre outros assuntos de interesse geral.

Depois de a seqüência anterior ter registrado muitas informações sobre literatura brasileira, na terceira coluna deste segmento, Lúcia retomava a conversa com Amâncio e cita Theóphile Gautier, Theodore de Banville e Baudelaire, após terem falado, brevemente, de alguns escritores portugueses. Nesse momento, a bebida fazia com que Amâncio se imaginasse mais eloqüente: "acudiam-Ihe opiniões e juízos perfeitamente armados; percebia que as suas palavras causavam bom efeito; ia bem".

É também na terceira coluna que ocorre um evento teatral, quase cômico, quando: "Pereira e Nini conservavam-se um defronte do outro, igualmente concentrados e mudos; ela, porém com os olhos muitos abertos sobre Amâncio. O Pereira afinal ergueu-se, atravessou lentamente a sala, como um sonâmbulo, e foi estender-se em uma cadeira preguiçosa, que ficava junto à janela".

Foi só vibrar o piano na sala que Mme. Brizard logo sugeriu que seria melhor mudarem-se para lá. Além de mostrar-se conhecedora de literatura, Lúcia tocou o Guarani "com muita energia e destreza [...] Depois da música principiou a simpatizar com ela; já gostava de a ver, misteriosa e pálida e melancólica e arrastar-se pela casa com a languidez de uma convalescente" [ $4^{\mathrm{a}}$ e $5^{\mathrm{a}}$ Colunas].

O corte desta seqüência ocorre com a chegada dos hóspedes que não estavam na casa de pensão durante o jantar. Paula Mendes e a mulher, no auge de uma briga. 


\subsubsection{Oitava seqüência: 07 de abril (23)}

A chegada do advogado retoma o assunto desenvolvido na seqüência anterior, pois é inserido um novo personagem à narrativa. Enquanto muitos estavam a dormir pelos cantos, o Dr. Tavares estava alegre: "Estivera em casa de um amigo, pessoa de muita consideração, onde se reunia a mais fina sociedade". Sem conseguir cessar aquele entusiasmo, o Tavares orava e "vários hóspedes recolhiamse para os seus quartos, atravessando na ponta dos pés o corredor do fundo da varanda, para não serem obrigados a ouvi-lo".

Tomando como referência um excerto que não foi preservado na versão em livro, a terceira coluna também destaca a voz do advogado que, mais calmo, "assentou-se de novo, disse as causas que havia defendido na província: algumas das quais, exclamava com vanglória, eram de assassinos e criminosos de tal ordem, que, se não fosse ele, nunca obteriam o perdão de um santo!"

Enquanto isso, "Amâncio principiava a sentir-se entediado [...], quis retirar-se; não Iho consentiram". Diante da ameaça de chuva, resolveu ficar e já era mais de uma hora quando todos se recolheram.

O Capítulo VII é encerrado na quarta coluna deste segmento, quando Amâncio se recolhe ao quarto e Coqueiro lê para ele este verso: "Estamos em plena Roma. Os Césares devassos...".

\subsection{Capítulo VIII - dois segmentos}

É também na quarta coluna que se inicia o Capítulo VIII, com o seguinte gancho: "Amâncio sentiu um grande alívio, quando se achou afinal inteiramente só; a porta [do quarto] bem fechada e a luz do bico de gás quase apagado".

Motivada pela técnica folhetinista de "conduzir para trás", a quinta e a sexta coluna apresentam um lance teatral, de modo muito mais acentuado no romanceseriado, decorrente das lembranças que vinham à mente de Amâncio, embaladas pelo barulho da chuva e conduzidas pelo efeito do vinho. Nesse momento, Amâncio deixava-se guiar por pensamentos que the traziam imagens femininas, em procissão: 
Aquilo fazia lembrar a Amâncio as noites de inverno, que passara na fazenda da avó, ouvindo cair a chuva do telhado, - as janelas fechadas, a canja de marrecas a fumegar sobre a mesa, o vinho de caju a luzir nas garrafas de vidro branco.

- Que bom que era! Ele gostava muito dessas ceiatas em casa da boa velha, aí tinha liberdade, podia fumar seu cigarrinho desassombradamente, a mexer com as crias da avó. Bem bom tempo!

$\mathrm{E}$, sem parar ia-Ihe com a imaginação construindo um pedestal, um trono no seu entendimento.

Ela aparecia-lhe agora mais bela, radiante, cercada de um prestigio adorável de talento e ilustração. Amâncio a respeitava instintivamente, sentia-lhes as agulhas do espírito entrarem-Ihe pela pele, e entrarem-se-lhe pelo corpo, até $\left(\ldots{ }^{14}\right)$ o coração.

$\left(\ldots{ }^{15}\right)$ Amelinha em um tom mais duvidoso e mais delicado, aparecia sorrindo com os seus dentes adoráveis, o seu narizinho arrebitado, os seus olhos piscos, mas a imagem desta não se firmava, não se fixava como a outra.

E a procissão continuava (...).

O corte desta seqüência ocorre quando as imagens se fragmentavam e Amâncio: "Não via mais coisa alguma - adormecera".

\subsubsection{Conteúdo retirado da versão em livro e não localizado no romance- seriado}

\subsubsection{De casa de Campos à casa de pensão de Coqueiro}

Há uma descrição romântica do despertar de Amâncio, depois de um dia cheio de novidades. Ao abrir a janela do quarto, um "jato de luz dourada invadiu-lhe a alcova" (CP, 1977, p. 72). A chuva que o impedira de ir embora, havia limpado a atmosfera, deixando aquela manhã com um frescor muito agradável. Enquanto ele observava o vaivém dos trabalhadores, entendia naquele movimento um chamado: "Amâncio sentiu vontade de sair e andar à toa pelas ruas. Todo ele reclamava longos passeios ao campo, por debaixo de árvores, em companhia de amigos" (CP, 1977, p. 73).

O espírito sensual do maranhense foi aflorando quando bate na porta

uma mucamazinha, que já na véspera lhe chamara por várias vezes a atenção durante o jantar [...].

Teria quinze anos, forte, cheia de corpo, um sorriso alvar mostrando dentes largos e curtos, de uma brancura sem brilho.

\footnotetext{
${ }^{14}$ llegível.

15 Ilegível.
} 
Vinha saber se o Dr. Amâncio queria o café antes ou depois do banho.

Amâncio, em vez de responder, agarrou-lhe o braço com um agrado violento e grosseiro. Ela pôs-se a rir aparvalhadamente ${ }^{16}$.

As sensações somadas à atitude atrevida de Amâncio podem ser aplicadas à "temática dos vícios e amor selvagem", embora seja característica do romanceseriado. No entanto, esse acontecimento não é explorado com detalhes, ou seja, apesar de sabermos que Amâncio foi correspondido, não sabemos o que ocorreu entre ele e a jovem mucama.

Pressupomos que tudo que Amâncio vira e sentira naquela casa foi suficiente para convencê-lo de mudar-se, definitivamente, para aquela casa de pensão, o que Ihe fez revelar a Campos: "que afinal descobrira em casa da família de um amigo o cômodo que procurava". O comerciante aprovou a escolha de Amâncio, pois a casa de pensão de Mme. Brizard era extremamente conceituada naquela época. Amâncio agradeceu por todos os favores, despediu-se de Campos e pediu licença para despedir-se de D. Maria Hortênsia, não perdendo a oportunidade de assediá-la, fazendo-a refletir: "- Seria possível, pensava ela - que aquele estudante the quisesse fazer a corte?... Não! não seria capaz disso, e, se fosse, ela saberia desenganá-lo! Ah! com certeza que o desenganava!" (CP, 1977, p. 74).

Ficou decidido que os dois iriam ao baile oferecido na casa do Melo. Amâncio estava surpreso por ver Hortênsia corresponder aos seus sentimentos, por isso torturava-se por saber que logo agora estava saindo de perto dela:

- E agora é que vou deixar a casa!...pensava ele já na rua .- Que tolo fui! Abandonar a empresa, justamente quando me sorri a primeira esperança! "Mas pedaço de asno, argumentava com seus botões - não calculaste logo que aquela mulher mais dia menos dia, havia de escorregar? Porque diabo então não esperaste um pouco?..... Ora! mas que caiporismo o meu! Sair nesta ocasião! Perder uma conquista tão boa! Agora também que remédio Ihe ei de dar? O que está feito, está feito! A este momento minhas malas talvez já tenham chegado à casa do Coqueiro! $E$ com este nome assaltaram-lhe logo o espírito as imagens de Lúcia e Amelinha ${ }^{17}$.

De um dia para o outro, Amâncio se via cercado por muitas mulheres interessantes, o que the fazia lembrar do que dizia o Simões: "Quando te começarem as aventuras, hás de ver o que vai por esta sociedade!"

\footnotetext{
${ }^{16} \mathrm{CP}, 1977$, p. 73

${ }^{17}$ Ibidem, p. 75.
} 
E Amâncio, que não conseguia reter na cabeça as palavras dos seus professores, Amâncio, que era incapaz de guardar na memória um fato, um algarismo, uma fórmula científica, conservava, entretanto, com toda a inteireza aquela frase banal, pronunciada por um pândego em um almoço de hotel, depois de meia dúzia de garrafas de vinho ${ }^{18}$.

A frase dita por Simões estabelece um gancho com o segmento seguinte.

\subsubsection{Primeira seqüência: 11 de abril (24)}

\subsubsection{Principais ações desta seqüência}

Coluna 01 - Início: "O Paiva [livro: Simões] tinha toda a razão... principiavam as aventuras! Diabo era aquela asneira de abandonar tão intempestivamente a casa do Campos! Fora uma triste idéia, que dúvida!"

Coluna 02 - Amelinha, bem contra a sua intenção, soltou uma risada, que desfez por instantes o ar inocente de sua fisionomia. Mas recuperou-o logo, e lembrou à cunhada "que não podiam roubar daquele modo o tempo a seu Amâncio. As malas já estavam no quarto. Ele tinha de arrumá-las!"

Coluna 03 - "Nesse momento Amâncio acabava de abrir as janelas do seu quarto, arrastava as malas para o centro e ia tratando de abri-las. As duas apareceram".

Coluna 04 - "À proporção que se iam tirando as peças de roupa $\left(\ldots{ }^{19}\right)$ do baú uma tepidez doce e confortável, que lembrava o aconchego morno da família. Cada objeto trazia ao provinciano mil reminiscências e mil saudades de sua mãe [...]. Uma vaga tristeza apoderou-se dele [...]. Afigurava-se-Ihe que um pouco da sua infância, um pouco de sua mãe, fugiam para sempre com aqueles perfumes que se evaporavam [...]".

Coluna 05 - "E saiu do quarto para enxugar as lágrimas [...] Quando voltou ao quanto já os baús estavam despejados".

\footnotetext{
${ }^{18}$ Ibidem.

19 Ilegível.
} 
Coluna 06 - "O rapaz estava muito bem provido de um tudo! Não Ihe faltava nada, dizia a velha em voz baixa. E depois de uma pausa, acrescentou mais alto, rindo: Podia até se casar, se quisesse!" "Falta o principal, respondeu ele. - O que é acudiu logo Amélia. - A noiva! Explicou ele, olhando intencionalmente para a rapariga”.

Final: "Não sei porque [não podia casar como uma provinciana], volveu Amâncio, escandalizado. - Na província há meninas [livro: senhoras] muito bem educadas, muito chics!"

\subsubsection{Técnicas básicas do padrão narrativo do romance-seriado}

Além dos diálogos que se acentuam na última coluna deste segmento, a técnica de "conduzir para trás" (RIBEIRO, 1996, p. 45) é retomada quando: “a proporção que se iam tirando as peças de roupa $(\ldots)^{20}$ do baú uma tepidez doce e confortável, que lembrava o aconchego morno da família. Cada objeto trazia ao provinciano mil reminiscências e mil saudades de sua mãe $(. . .)^{21}$. Naquele momento, Amâncio percebia que "à semelhança daquelas arcas, havia também de ir perdendo, pouco a pouco, todas as ilusões, todos os perfumes, com que saíra da casa dos seus pais". Enquanto o romance-seriado apresenta riqueza de detalhes para esta cena, demonstrando a fragmentação das lembranças que Amâncio trazia consigo do Maranhão, o livro editado por Faro \& Lino apresenta uma ilustração da retirada das roupas do baú.

\subsubsection{Segunda seqüência: 12 de abril (25)}

Coluna 01 - Início: "Ah! sei, sei perfeitamente! disse Mme. Brizard, para não contrariá-lo. Sei que as há ... mas o senhor merece ainda mais!”

Coluna 02 - "[as provincianas] Querem sedas, carruagens, teatros e bailes toda a noite, não se contentam com qualquer casa, não admitem menos de seis ou oito criados, enfim todas as suas horas são poucas para cuidar nas festas".

\footnotetext{
20 llegível.

21 llegível.
} 
Coluna 03 - "Amâncio declarou que as exceções não serviam de argumento. - Ele não queria dizer que as fluminenses eram todas exigentes, como não podia afiançar que nunca viria a casar com alguma delas [livro: e não tinha a pretensão de dizer 'desta água não beberei, deste pão não comerei!']"

\subsubsection{Técnicas básicas do padrão narrativo do romance-seriado}

O início desta seqüência ocorre com a continuidade do que estava sendo desenvolvido na anterior, quando Mme. Brizard tenta, embora não consiga, não contrariar Amâncio. A conversa acaba dividindo as opiniões dos dois, à medida que a francesa toma partido das mulheres fluminenses e Amâncio das maranhenses. Daí, há uma continuidade com os diálogos (discursos diretos) iniciados no segmento anterior e interrompidos quando Amélia deixa cair uma pilha de camisas. Novamente, podemos perceber a presença da técnica folhetinesca do "acaso como ponto de convergência entre alguns acontecimentos da narração", causando corte nas ações desenvolvidas até o momento.

\subsection{Capítulo IX - nove segmentos}

\subsubsection{Primeira seqüência: 12 de abril (continuação) (25)}

Coluna 04 - "O baile em casa do Melo esteve bom. A casa [do Melo] prestava-se maravilhosamente, e a noite, um pouco sombra e fresca, concorreu sob maneira para o bom eleito da festa".

Coluna 05 - "Até Carlotinha parecia mais expansiva".

Coluna 06 - "[...] ele empertigava-se todo com graça, cravando o olhar no alto, e a rodar extasiado, embevecido como se fosse arrebatado em sonho por entre nuvens cor de rosa. E [Amâncio] parecia não cansar, só parava quando a dama [Hortênsia] o constrangia a isso". 


\title{
1.9.1.1 Técnicas básicas do padrão narrativo do romance-seriado
}

O corte sistemático realizado no segmento anterior propicia o início de um novo evento, já anunciado no diálogo entre Hortênsia e Amâncio, quando este deixava a casa de Campos para hospedar-se na casa de pensão de Coqueiro. $\mathrm{Na}$ ocasião em que se despediram, ficou combinado que se veriam novamente no baile do Melo, apresentado nesta seqüência. No início, são apresentados muitos detalhes sobre a casa do anfitrião, a alegria dos convidados e a empolgação de Amâncio. O corte deste segmento explora a "temática dos vícios e amor selvagem" de Amâncio:

\begin{abstract}
Seu temperamento, excessivamente lascivo, comprazia-se em sentir ligado ao seu corpo o corpo precioso de uma mulher de estimação; deliciava-se em beber-lhe o hálito acelerado pela dança, embebedava-se com respirarIhe os perfumes agudos do cabelo e o infiltrante cheiro animal da carne (CP, 1977, p. 79).
\end{abstract}

\subsubsection{Segunda seqüência: 13 de abril (26)}

Coluna 01 - Início: "Afinal, depois de uma valsa, infracto estonteado, atirou-se ofegante ao canto do divã em que estava Hortênsia".

Coluna 02 - "Hortênsia procurava uma saída; não se animava a dizer que era para não contrariar o marido, que não gostava de a ver valsar".

Coluna 03 - "Pares cruzavam-se no meio da sala do Melo, formando as marcas da contradança, aos gemidos histéricos das rabecas; um cheiro híbrido de extratos adoríferos das flores que se fanavam em grandes vasos japoneses e de sutil pituita dos corpos fatigados das mulheres, espalhavam-se no ambiente cor de pérola e penetrava a carne com a subtilidade de um veneno lento e delicioso como o fumo de um tabaco".

Coluna 04 - Conteúdo que somente foi registrado no romance-seriado: "Ela não resistiu, levantou-se de um salto e entregou a cintura ao moço, que a prendeu logo nos braços com a delicadeza langorosa de quem toma nas mãos uma imagem de cera".

Coluna 05 - "Quando parou a música Hortênsia, caiu sobre um divã pelos braços de Amâncio". 
Coluna 06 - "Foi a voz do marido que a chamou a si".

Final: "Nessa ocasião, Amâncio encostado ao bufete, pedia que the servissem um grogue à americana".

\subsubsection{Técnicas básicas do padrão narrativo do romance-seriado}

Nesta seqüência ocorrem "lances teatrais abundantes com bruscas mudanças inesperadas nos episódios" (RIBEIRO, 1996, p. 45). No romance-seriado há maiores detalhes e suspense entre os momentos que envolvem Hortênsia e Amâncio, em meio ao embalo de música. Os dois parecem entregues às sensações causadas com o contato dos corpos, até que a chegada de Campos dissipa o delírio que os envolvia. No entanto, Amâncio ignora o mau humor do comerciante.

\subsubsection{Terceira seqüência: 17 de abril (27)}

Coluna 01 - Início: "- Está retemperando a filha? perguntou-Ihe um sujeito magrinho, elegante, meio calvo, a bater-Ihe amigavelmente no ombro".

Coluna 02 - "Amâncio, porém, desculpava-se com a falta de tempo; fazia-se muito ocupado, mas havia de aparecer, mais tarde, mais tarde!"

Coluna 03 - "As mulheres eram o seu fraco, eram o seu vício; várias anedotas suas a esse respeito corriam de boca em boca há vinte anos".

Coluna 04 - "Amâncio protestava com um sorriso pretensioso".

Coluna 05 - "O Freitas deixou-se levar, sempre muito enfastiado; mas, antes de ir, bateu no ombro de Amâncio e segredou-lhe com a sua voz pobre [livro: de tuberculoso]: Aproveita, menino, aproveita! Não mandes nada ao bispo!"

Coluna 06 - Final da festa na casa do melo: "Foi Amâncio que ajudou Hortênsia a entrar na carruagem [...]. Logo, porém, que o cocheiro sacudiu as rédeas, ela chegou o rosto à portinhola, e gritou para fora: - Aparece Domingo! Vá jantar 
conosco. Adeus! [...] - Adeus, minha senhora. Hei de ir [...] $O$ animal disparou, sacudindo as crinas ao vento fresco da manhã".

\subsubsection{Técnicas básicas do padrão narrativo do romance-seriado}

O "corte com gancho no final do segmento" deixa em aberto um novo encontro entre Amâncio e Hortênsia, causando expectativa por parte dos leitores. A despedida descrita na última coluna também pode ser descrita em "lances teatrais abundantes com bruscas mudanças inesperadas nos episódios" e com o indício de que Hortênsia poderia estar envolvida por Amâncio. A terceira coluna retoma tudo o que já foi dito sobre o lado conquistador do maranhense, como se esse vício não pudesse ser desassociado de sua existência. Então, podemos entender que esse é o motor propulsor da narrativa.

\subsubsection{Quarta seqüência: 19 de abril (28)}

Coluna 01 - Início: "Amâncio acendeu um charuto e derreteu-se para trás com os olhos meio cerrados".

Coluna 02 - "Como poderia agora acreditar nas virtudes femininas?... Pois se até aquela! pois se até a mãe a mulher do Campos falhara!...".

Coluna 03 - "Bem me dizia há pouco o Dr. Freitas [no baile do Melo]: - Para conquistar as mulheres são necessárias apenas quatro coisas: 'audácia, boas relações, um pouco de inteligência e não ser seu marido!".

Coluna 04 - "Dormiu mal; os sonhos não o deixaram a noite inteira. A princípio, todavia, foram agradáveis: ternos episódios de amores fáceis que se encadeavam confusamente, e nos quais a sensações vinham e fugiam de um modo vago e delicioso; depois chegavam os sonhos maus, os pesadelos".

Coluna 05 - "Não podia suportar aquele homem! aquele maldito velho Vasconcelos, que no sonho não Ihe aparecia como pai, mas como um senhor mal, bruto". 
Coluna 06 - "Amâncio, enquanto o Lambertosa discorria sobre a dália, leu mais uma vez o cartão. Quando levantou os olhos reparou que Nini o fixava ainda com mais insistência. Amélia dera-se por incomodada e não veio à mesa”.

\subsubsection{Técnicas básicas do padrão narrativo do romance-seriado}

Estabelecendo continuidade com a seqüência anterior, a primeira coluna registra o momento em que Amâncio volta para casa, depois do baile na casa do Mendes, amigo da família de Coqueiro.

Os pensamentos de Amâncio retomavam as imagens absorvidas daquela noite, sentia-se vitorioso, como havia previsto o Dr. Freitas na coluna três. Além de ter conseguido dançar com Hortênsia, na despedida, ela o havia convidado para um jantar em sua casa no próximo domingo, ao qual ele aceitou de imediato. Esses últimos acontecimentos mostravam que Hortênsia não era honesta como havia imaginado. Desse modo, pressentia que ela: "o desejava ardentemente, que se entregaria na primeira ocasião, fazendo loucuras, dando escândalos, que nem uma heroína de romance!"

Os pensamentos de Amâncio, entretanto, nunca vinham sem os pesadelos, que sempre estavam associados à voz grossa do pai, que, inconsciente, lhe repreendia. O recuo temporal, com a técnica de "conduzir para trás", retoma uma das principais técnicas composicionais de Casa de Pensão, alternando os tempos cronológico e psicológico, no vaivém dos pensamentos do protagonista. Na quarta coluna, é descrito seu lado ludibriador, pois:

\footnotetext{
Sem saber a razão por que, todo o seu desejo, todo o seu gosto era enganar os outros homens. Os seus semelhantes apareciam-lhe sempre na figura antipática do seu pai e do seu professor. Nunca os conseguiu amar; nunca compreendeu o altruísmo com que nos sacrificamos pelos outros, não hesitaria em pregar-lhe alguma deslealdade. O mal o atraía com a irresistibilidade de um vício antigo e inconfessável.
}

No romance-seriado, a citação sobre como Amâncio tinha dormido corresponde ao início do Capítulo $X$, da versão em livro. A mesma voz que havia lançado o maranhense em pesadelos é retomada na coluna cinco, quando Amâncio se vê aprisionado: Queria gritar, correr, mas a língua inchava-lhe na boca e as pernas pareciam troncos de árvores, seguras ao chão. 
E instaurado grande suspense no final desta seqüência, quando a última coluna registra um acontecimento inesperado - Amâncio recebe um ramalhete de flores, acompanhado de um cartão com a seguinte frase: ao Dr. Amâncio de Vasconcelos - de uma amiga. Cheirou o pequeno pedaço de papel e pensou sentir o perfume de Hortênsia, "que na véspera havia lhe entrado até a medula".

\subsubsection{Quinta seqüência: 24 de abril (29)}

Coluna 01 - Início: "O jantar correu muito frio e constrangido ao princípio; pouco se conversava e quase ninguém tinha vontade de rir".

Coluna 02 - "- Agora temos choro!... pensou Amâncio com tédio. Nini, como se adivinhara tal pensamento, olhou para ele e pediu-lhe perdão com um grande olhar piedoso e infeliz".

Coluna 03 - "-Esta infeliz menina! exclamou, depois de um entroite de vinte minutos - esta infeliz menina, senhores! nada mais é do que uma imbele vítima de todos os impulsos, que $\left(.{ }^{22}\right)$ haver no coração terno e carinhoso da mulher! Vede como o seu semblante é meigo e dolorido, como seus olhos falam a misteriosa linguagem do amor, como a sua boca...".

Coluna 04 - "O Coqueiro também pediu ao advogado que se calasse". Este fragmento somente existiu no romance-seriado: "Não! não me calarei! berrava ele Não me calarei, porque a causa do oprimido é a minha causa! não me calarei, porque meu silêncio pode fazer vacilar a balança da justiça!"

Coluna 05 - "Amâncio, surpreso e contrariado, quis evitá-la, mas a enferma passouIhe os braços em volta do pescoço, encostou-lhe a cabeça no colo e desatou um choro histérico".

Coluna 06 - "Olhe, disse-Ihe Amâncio. - Lá dentro estão a chamando! Vá! Vá! Ela, nem assim fez caso".

Corte com gancho: (Uma cena de histerismo) "Correram todos par a sala de visitas; acenderam-se os candeeiros. Nini estercia-se no chão, a gritar, esfrangalhando as roupas e mordendo os punhos".

\footnotetext{
22 llegível.
} 


\subsubsection{Técnicas básicas do padrão narrativo do romance-seriado}

Nesta seqüência, podemos notar a presença da "estética divergente e centrífuga", que engloba o desânimo de todos durante o jantar, a discussão sobre casamento como solução para o histerismo e a crise histérica de Nini. Mais uma vez o acaso redireciona o foco narrativo, e todos se esquecem das flores recebidas por Amâncio pouco antes do jantar.

\subsubsection{Sexta seqüência: 25 de abril (30)}

Coluna 01 - Início: "Coqueiro e Mme. Brizard apoderaram-se logo dela [a histérica Nini]. Amâncio apareceu com o seu frasquinho de vinagre".

Coluna 02 - [Comentário sobre Lúcia] "Deram-Ihe professores de francês, de música, de desenho; entregaram-lhe enfiadas de romances banais do gênero de Mistério da Tijuca e livros de maus versos; e, todavia, não Ihe deram moral, nem trataram de lhe formar o caráter".

Coluna 03 - "Pereira deixou-se seduzir, sem mesmo dar por isso. Explicaram-se pela primeira vez no Jardim Botânico! um domingo que Lúcia passou ali com a família".

Coluna 04 - "O velho morreu de repente, de uma congestão apanhada três dias depois que encontrou Lúcia no jardim com um estudante da vizinhança".

Coluna 05 - "Principiou então para eles [Lúcia e Pereira] um viver perfeitamente de boêmios. Sem trates, sem dinheiro, sem futuro, sem relações constituídas [...] sempre sobressaltados, sempre perseguidos pelos credores que iam deixando atrás de si".

Coluna 06 - "O menino fora muito franzino e muito mole - saíra ao pai, o Pereira. Durante o seu pobre mês de vida só abriu os olhos uma vez, ao expirar". 


\subsubsection{Técnicas básicas do padrão narrativo do romance-seriado}

Depois do relato da crise de histerismo de Nini, filha da Mme. Brizard, esta seqüência relata o momento em que Coqueiro tenta acalmar a cunhada. Quando tudo volta à normalidade, o foco recai sobre Lúcia e seu marido Pereira. Como estratégica exclusiva da versão folhetinesca, Aluísio retoma a temática da literatura e a linguagem metalingüística, para caracterizar a educação recebida por Lúcia, pois: "deram-Ihe professores de francês, de música, de desenho; entregaram-Ihe enfiadas de romances banais do gênero de Mistério da Tijuca e livros de maus versos; e, todavia, não Ihe deram moral, nem trataram de lhe formar o caráter". O contraste entre o vasto conhecimento sobre música e literatura e a falta de educação revela que Lúcia vivia de golpes, desprezando todo conhecimento que poderia garantir seu sustento de maneira honesta. Sem preservar a referência do romance-seriado citado, no livro há apenas uma alusão ao gênero, por ter sido substituído por "livros de maus versos" 23 .

Simultaneamente, a temática do "acaso" e a técnica de "conduzir para trás" são aplicadas para explicar os motivos que levaram Lúcia à vida boêmia e desregrada. Das experiências amorosas, a que mais the causou frustração foi provocada pelo primo que, depois de seduzi-la, abandonou-a. De volta para a casa da família, sofrendo humilhações, Lúcia decidiu dar um jeito em sua vida. O golpe planejado por Lúcia pode ser relacionado à técnica folhetinesca que foca "a situação social insatisfatória", pois o casamento por interesse poderia significar mudança de situação, embora não tenha acontecido nesse caso, pois o tio de Pereira não deixou herança para o sobrinho. A coluna três apresenta outro "acaso" para explicar o fato de Lúcia trair o marido - conforme relatado na coluna quatro - considerando o fato de Pereira não satisfazer seus desejos:

Só no fim de quatro dias de lua-de-mel, como ela teimasse nas suas idéias matrimoniais, declarou ele, com toda a calma, que não lhe podia fazer a vontade, porque desde os seus dezoito anos o haviam casado com uma velha, uma fúria, que ele não sabia, nem queria saber, por onde andava.

Além de trair o marido com um estudante, a versão folhetinesca também revela que Lúcia tentou, em vão, fazer aborto. Repetiremos a citação feita no último parágrafo desta seqüência, para ressaltar o humor empregado para comparar o filho

\footnotetext{
${ }^{23}$ Casa de pensão, 1977, p. 88.
} 
ao pai: "- O menino fora muito franzino e muito mole - saíra ao pai, o Pereira. Durante o seu pobre mês de vida, só abriu os olhos uma vez, ao expirar".

\subsubsection{Sétima seqüência: 26 de abril (31)}

Coluna 01 - Início: "A casa de pensão do Coqueiro era a sexta que Lúcia percorria com o suposto marido". "Quando constou a Lúcia que Amâncio era rico e atoleimado, uma esperança nova radiou-Ihe no coração".

Coluna 02 - "E ele, embriagado de satisfação, lia e relia o bilhete, repetindo mentalmente a todo instante: 'Eu te amo Amâncio'”.

Coluna 03 - "Sim tudo estava a dizer que o tal bilhete era de Lúcia!... Aquelas frases poéticas, aquele mistério, aquela franqueza de confessar o seu amor em duas palavras... Não tinha que ver! - era dela! Era da mulher do Pereira!"

Coluna 04 - "Levantou-se, enfiou o sobretudo e saiu do quarto. O sangue não lhe queria ficar quieto".

Coluna 05 - "E o 8 de Lúcia, da misteriosa Lúcia. - Ela estava ali!... Fazendo o quê... pensando nele, talvez... talvez dormindo...”.

Coluna 06 - Corte com gancho: "Hipócritas! resmungou ele. E encaminhou-se para o segundo andar".

\subsubsection{Técnicas básicas do padrão narrativo do romance-seriado}

Esta seqüência é marcada pelo didatismo narrativo, à medida que são retomadas questões interrompidas sem que fossem totalmente desenvolvidas. Além disso, este segmento traz à tona registros anteriores, como gancho para novas situações.

O suspense, causado quando Amâncio recebeu flores, que estavam acompanhadas de um bilhete anônimo, é desvendado quando o autor revela, na primeira coluna, que: "Quando contou a Lúcia que Amâncio era rico e atoleimado, uma esperança nova radiou-lhe no coração. - É agora!... disse. E preparou-se para 
o combate". Depois disso, são acrescentadas reflexões, a partir das quais Amâncio também desvenda o mistério existente por trás do bilhete, quando o personagem chega à conclusão de que apenas Lúcia tinha a habilidade de utilizar as palavras daquela forma. Ao reler este bilhete, registrado na segunda coluna, não lhe restavam dúvidas.

Não saibam nunca espíritos indiferentes, nem mesmo tu, adorado fantasista, quem te envia estas pobres flores. Não o procures descobrir; deixa que o meu segredo viceje e cresça na tepidez do mistério, à semelhança das plantas melancólicas que reverdecem nas sombras ignoradas dos rochedos. Eu te amo!

Após desvendar o mistério, Amâncio não consegue deixar de pensar em Lúcia, o que retoma as informações apresentadas na seqüência do dia 10 de março, quando o protagonista planejava ir para o Rio de Janeiro, onde poderia viver "aventuras inesperadas e amores, amores principalmente". No entanto, nessa noite, Amâncio encontra vários empecilhos, que o impedem de aproximar-se de Lúcia.

No momento em que anda pelos corredores para tentar encontrar o quarto de Lúcia, Amâncio flagra a saída de um casal de um dos quartos: o médico do quarto número 11 estava recebendo visita íntima. Nesse momento, há a aplicação da técnica da narrativa folhetinesca de "conduzir para trás", com a retomada de informações vinculadas ao dia em que Coqueiro lhe apresentou a casa de pensão. No segmento registrado no dia 31 de março, Coqueiro ressalta que Amâncio não poderia receber "certas visitas...", acrescentando: "- Sim! Sabes que isto é uma casa de família e, para a boa moral...". Amâncio, por sua vez, finge concordar: "Certamente! E acendeu um cigarro". Ao perceber que a regra citada pelo proprietário não se aplicava aos demais moradores, o maranhense exprime as seguintes palavras: - "Hipócritas! resmungou ele. E encaminhou-se para o segundo andar". Desse modo, esse último parágrafo apresenta um gancho com o próximo segmento.

A recomendação de coqueiro também representa um gancho ao conteúdo apresentado no Capítulo XII, do livro:

\footnotetext{
- Isto aqui é uma casa de família! Sabes perfeitamente que temos conosco uma menina solteira, - uma virgem! Não é por mim, nem por ti, nem tampouco pela Lúcia; mas é por ela, sebo! por - minha irmã! - a quem sirvo de pai! É por minha mulher, é por minha enteada e pelo menino, é pelos hóspedes, enfim!...

- Pois acredita que não houve nada demais!...balbuciou Amâncio.
} 
- Não, filho, tem paciência! Lá fora o que quiseres, mas daquela porta para dentro, não admito, nem posso admitir!...E passeando pelo quarto com as mãos nas algibeiras: - Que diabo! Eu te preveni!...

- Ora o quê! Resmungou Amâncio , indignado com a hipocrisia do colega, mas sem coragem para dizer o que sabia a respeito dele e dos costumes da casa. - Não abro o exemplo!...acrescentou (CP, 1977, p. 119-120).

\subsubsection{Oitava seqüência: 29 de abril (32)}

Coluna 01 - Início: "Subiu pela escadinha do fundo, a que ficava do lado contrário a outra por onde, ainda há pouco, descera o médico".

Coluna 02 - "E quedava-se encostado à porta do $n^{0} 8$, deixando-se comer aos bocadinhos por suas idéias concupiscentes; ao passo que lhe arfava o corpo inteiro com o resfolegar aflitivo dos pulmões".

Coluna 03 - "Seu desejo, estimulado e inquieto, evocava todos os meios de saciarse; descobria hipóteses absurdas, inventava possibilidades que não existiam. Amâncio pensou em Amélia, em Mme. Brizard, na mucama, e até, que horror! em Nini!"

Coluna 04 - Ao passar pelo quarto de Mendes, pensou: "- É porque a mulher está dormindo, pensou este, lembrando-se [livro: do mau gênio de Catarina] da noite que os viu pela primeira vez. E considerou sobre a existência ordinária que levariam ali, aquelas criaturas tão opostas encurraladas no mesmo quarto, obrigadas a esbarrarse de vez em quando".

Coluna 05 - "A paciência inventou-se para consolar os tolos! Farte-se você com ela! De conselhos estou cheia, meu amigo! Quero obras e não palavras! O Mendes não respondeu".

Coluna 06 - "- Arre, com os diabos! Que nem se pode dormir!"

Coluna 07 - "Ó mulher! Cala essa boca do diabo! Gritou, afinal, o Mendes, arremessando a pena e empurrando os papéis que tinha defronte de si. - Arre! Ë muito! Arre!" 
Final: "Ora, com um milhão de demônios! Gritou o guarda-livros, que ficava no n. ${ }^{\circ} 6$ Não é possível sossegar neste inferno! Quando não é a tosse e o gemido da direita, é a rezinga e a briga da esquerda! Antes morar num hospital de doidos!"

\subsubsection{Técnicas básicas do padrão narrativo do romance-seriado}

Este segmento estabelece conexão com o anterior, ao mesmo tempo em que retoma as descrições feitas na seqüência do 11 de março, quando o protagonista revela os obstáculos que cercaram os seus primeiros amores. Na medida em que percebe que a presença do marido de Lúcia o impedia de aproximar-se, Amâncio passa a vagar pela pensão, continuado a pensar em alternativas para satisfazer seu desejo, quando, mais uma vez, a técnica folhetinesca do "acaso" acaba desviando seus pensamentos e o foco narrativo.

Ao passar pelo quarto 07, Amâncio ouve o gemido do doente que se hospedava ali, então se afasta. À porta do quarto do Mendes, ouve barulho de papéis, o que revela que este ainda trabalhava, enquanto a mulher insistia que o marido fosse dormir. Há um destaque especial ao impasse existente entre Mendes e Catarina, como fruto das diferenças existentes entre o casal. Depois de muito suportar a exasperação da mulher, Mendes manda-a calar a boca, em meio a muitas outras palavras de baixo calão, como traço característico da linguagem oral.

A técnica narrativa do "corte com gancho" é aplicada em tom humorístico, quando, no último parágrafo deste segmento há a inserção de um novo evento: o guarda-livros decide dar um basta aos ruídos que o impedem de dormir, chegando a comparar a casa de pensão de Coqueiro a um hospício. O silêncio evocado com esse "basta" também instaura um suspense quando ao que poderia ser revelado no próximo segmento.

Há uma particularidade estrutural nesta seqüência, que repete a distribuição feita em sete colunas, realizada no segmento publicado no dia 11 de março.

\subsubsection{Nona seqüência: 01 de maio (33)}

Coluna 01 - "Mendes levantou-se, segurando a cabeça com uma das mãos, e começou a passear agitado pelo quarto". 
Coluna 02 - No romance-seriado esta coluna registra o final do Capítulo IX, com este parágrafo: "Amâncio já estava entre os lençóis, quando o Coqueiro percorreu toda a casa, de robe-de-chambre e um castiçal na mão".

\subsubsection{Técnicas básicas do padrão narrativo do romance-seriado}

Esta parte final do Capítulo IX estabelece continuidade com o anterior, apresentando as conseqüências do acúmulo de acontecimentos gerado naquela noite em que muitos dos hóspedes não conseguiam dormir, impedindo que os outros também dormissem. O emprego da técnica narrativa da "estética divergente e centrífuga" revela a progressão do alvoroço e a pressão que Coqueiro sentia para tomar providências imediatas. Desse modo, há um corte com gancho, porém, não há suspense, porque o Capítulo $X$ é apresentado na mesma coluna daquela que interrompe o anterior. Destacamos que, no livro, o Capítulo XI é inserido no lugar do $X$ do romance-seriado, o que significa mudança estrutural da apresentação dos capítulos.

\subsection{Capítulo $X$ - sete segmentos}

\subsubsection{Primeira seqüência: 01 de maio (continuação) (33)}

Coluna 02 - "O guarda-livros ao dia seguinte pela manhã mandou chamar um carregador e disse que deixava definitivamente a casa de pensão".

Coluna 03 - "As duas [Catarina e Mme, Brizard] atracaram-se. Os hóspedes, que estavam em casa, acudiram todos igualmente. Houve bordoada, gritos, palavrões. Nini teve um ataque de nervos".

Coluna 04 - "Virgílio, meus senhores, o imortal Virgílio, o verdadeiro fundador da eloqüência, diz muito acertadamente na sua Eneida, Livro IV, com referência à desditosa Dido - Pendet que iteram narrantis ab ore! Se podemos convencer com palavras, para que havemos de recorrer aos murros?!... [...] Coqueiro espantou-se. Querer trocar o gabinetesinho por um quarto do segundo andar?!...Ora, seu Amâncio!" 
Coluna 05 - "Então, perguntou aquele [Coqueiro], o que temos? Uma conferenciasinha. Ouve cá. E, depois de meterem-se ambos no vão de uma janela. Amâncio principiou com acentuações de quem detesta imoralidades".

Coluna 06 - "E, Amâncio, arrebatado pelos princípios morais, que ele só cultivava teoricamente, patenteou um gesto muito convicto de quem se preocupa em extremo com a pureza dos costumes".

Final: "E depois de trocarem ainda algumas palavras sobre o mesmo assunto, os dois rapazes desceram à chácara [desfecho deste episodio no livro (CP, 1977, p. 98): "os dois rapazes trocaram comovidos um enérgico aperto de mão e desceram juntos à chácara, onde, debaixo das latadas de maracujá, os esperavam as senhoras, palestrando em familiar camaradagem"].

\subsubsection{Técnicas básicas do padrão narrativo do romance-seriado}

Toda a confusão foi direcionada para um novo acaso. Depois de receber um sinal de Lúcia, Amâncio decide mudar-se para o segundo andar, deixando o guardalivros longe dos vizinhos ruidosos, ao mesmo tempo em que ficaria perto de Lúcia.

Na sexta seqüência, Amâncio expõe seu falso lado moralista, para manter as aparências junto a Coqueiro, ao adverti-lo do perigo de Nini assediar outros homens ou cair nas mãos de um "desalmado". Sem que o outro desconfiasse, Amâncio relata o que Ihe havia acontecido na noite anterior, no momento em que foi descrita a primeira crise nervosa de Nini, o que revela a utilização da técnica de "conduzir para trás". Por trás dessa conversa, estava a intenção de Amâncio justificar o porquê de mudar-se para o segundo andar, longe de Nini, mas, na realidade, era para ficar perto de Lúcia.

Ao ser retomado o falso moralismo de Amâncio, há um gancho com a seqüência número quatro, que apresenta a descrição da fisionomia interior do protagonista, e ela permanece inalterada durante toda a intriga do romance, com destaque para os motivos que tornaram Amâncio "reservado e fingido".

No romance-seriado, instaura-se grande suspense no final do episódio que trata da discussão sobre o histerismo de Nini. Na versão em livro, por outro lado, são acrescentadas informações que concluem esse evento, como se não houvesse mais nada a ser conversado sobre esse assunto. 


\subsubsection{Segunda seqüência: 04 de maio (34)}

Coluna 01 - "Dias depois, quando Amâncio já estava transferido para o n. 6 do $2^{\circ}$. andar, chegaram-lhe às mãos duas cartas; uma de sua mãe e outra de seu pai”.

Coluna 02 - "Amâncio releu várias vezes o que lhe dizia Ângela, e respirou largamente, como quem sai de um quarto apertado para um grande ar livre".

Coluna 03 - "Vasconcelos chegou tarde; encontrou já enrijado e duro o coração de seu filho".

Coluna 04 - "Não digo que te faças um santo, mas também não te afogues no torvelinho dos prazeres que aí há. Goza, meu filho, por isso que és moço, mas goza com prudência e com juízo. Diverte-te, mas evitando sempre tudo aquilo que te possa prejudicar".

Coluna 05 - "[...] doía-lhe a consciência por não ter sido melhor filho. Agora apareciam remorsosinhos penetrantes, como se o pobre rapaz contribuísse de qualquer modo para a insuficiência do seu amor".

Coluna 06 - Final - corte com gancho: "Foi desses elementos que Amâncio nunca dispôs para poder amar o pai".

\subsubsection{Técnicas básicas do padrão narrativo do romance-seriado}

O discurso narrativo evidencia a supressão de alguns dias, como se não houvesse nada mais interessante no intervalo entre a decisão de Amâncio mudar-se para o segundo andar e o momento em que o maranhense recebe duas cartas da família. As correspondências dos pais instauram mais uma vez o "acaso", como técnica capaz de redirecionar a narrativa.

A predileção pela mãe impulsiona-o a abrir a carta dela primeiro, mesmo ficando evidente que a carta do pai era a primeira que este escrevia especialmente a Amâncio. Na medida em que Amâncio lê a carta da mãe, a imagem de santa é retomada, à qual pode ser empregada a técnica da narrativa folhetinesca de "conduzir para trás", com a reapresentação do significado da figura materna à vida do protagonista. 
Entretanto, se a carta materna o impressionou, a outra o surpreendeu, pois desde a primeira linha pôde constatar que o pai lhe chamava carinhosamente de "Meu filho":

\begin{abstract}
Era também a primeira vez que apanhava de seu velho pai esse tratamento carinhoso e confortativo que é como um leite espiritual como que se alimentam as almas das crianças. Da viva voz o Vasconcelos nunca o tratara por tu; nunca Ihe dera a beijar [...] nunca Ihe aliviara enfim o coração, quando este se achava ainda brando e maleável, para depor aí um beijo fechado as sementes de ternura, que deveria mais tarde desabrochar $e$ produzir todos os bons sedimentos do homem.

Como poderia exigir de Amâncio que tivesse agora virtudes que não plantaram na estação propícia? Como se haveria de colher dedicação, heroísmo, coragem, energia, entusiasmo e honra, se de nenhuma dessas coisas the inocularam em tempo o germe necessário? [em destaque conteúdo que foi suprimido na versão em livro - CP, 1977, p. 98-99].
\end{abstract}

A presença de "didatismo narrativo" e da técnica da narrativa folhetinesca de "conduzir para trás" balizam as explicações dadas pelo narrador sobre os sentimentos do Vasconcelos, o que faz desta seqüência um marco da descaracterização da figura do pai carrasco. A partir de então, Amâncio chegou à conclusão de que o pai sempre o amara disfarçadamente. Logo é revelado que, por medo de que o filho não lhe respeitasse como deveria, Vasconcelos: "Muita vez chorou de ternura, mas sempre às escondidas; muita vez sentiu o coração saltar para o filho, mas conteve-se convenientemente, com receio de cair no ridículo". Então, são relacionados todos os elementos que faltaram à vida de Amâncio, como justificativa para a falta de amor pelo pai, o que encerra com suspense esta seqüência. Em complemento, o último parágrafo publica a voz do narrador, como forma de ressaltar que Amâncio não tinha culpa de não gostar do pai, uma vez que este nunca se deixou amar pelo filho.

\title{
1.10.3 Terceira seqüência: 09 de maio (35)
}

Coluna 01 - Início: "Depois da leitura da carta, Amâncio, pela primeira vez sentiu vontade de escrever para o pai". "Campos, que Ihe apareceu em seguida, veio corroborar esse desejo em vontade [...]".

Coluna 02 - “- Leia, leia e veja como está triste o pobre velho! Ah! meu amigo, acredite que - possuir um pai é a maior fortuna que se pode ambicionar nesta vida [livro: neste mundo]!" 
Coluna 03 - "Sempre que falar ao meu rapaz, tenha a bondade de aconselhá-lo, de lembrar-Ihe as obrigações, de dizer a responsabilidade que agora the assiste. Ele está se fazendo homem e precisa formar um futuro. Sirva-lhe de pai; acompanhe-o e proteja-o com o mesmo desvelo de que usou meu irmão para guiar a sua mocidade".

Coluna 04 - "Amâncio, que até aí ouvia o Campos em silêncio e com os olhos presos a um ponto, agradeceu-lhe muito aquele interesse e jurou que todo o seu empenho era corresponder à expectativa de seus pais e ser agradável o mais possível aos verdadeiros amigos de sua família".

Coluna 05 - "Oh! Os estudos! Os estudos eram a aza negra de sua vida, o espectro terrível de seus sonhos! por melhores que fossem as regalias que daí pudessem vir, nunca seriam capazes de compensar aquela profunda tristeza, o aborrecimento invencível, que o devoravam naquele momento".

Coluna 06 - "Todavia, desde a visita do negociante, principiou a freqüentar as aulas com mais assiduidade e a reter mais na memória o que lia nos compêndios".

Coluna 07 - "- O guarda-livros, no fim de contas era um tipo impossível: ninguém o podia compreender - tão depressa se passava de azul para o encarnado como do encarnado para o azul [No livro: tão depressa está para o norte como para o sul]!"

Final: Ilegível.

\subsubsection{Técnicas básicas do padrão narrativo do romance-seriado}

A reação surpreendente de Amâncio contradiz as revelações registradas na seqüência anterior, por isso a narrativa toma nova direção. Nessa perspectiva, quando Campos revela a Amâncio o conteúdo da carta que o Vasconcelos lhe escrevera, cresce no maranhense a vontade de escrever para o pai.

$\mathrm{Na}$ terceira coluna tomamos conhecimento de que os favores prestados pelo tio de Amâncio são cobrados, quando Vasconcelos solicita que Campos: "Sirva-Ihe de pai; acompanhe-o e proteja-o com o mesmo desvelo de que usou meu irmão para

guiar a sua mocidade". A esse evento podemos aplicar a técnica do "didatismo narrativo", na medida em que o autor retoma uma informação registrada na primeira seqüência do romance-seriado como justificativa para o pedido registrado na carta. 
$\mathrm{Na}$ sexta coluna, são registradas informações que somente existiram no romance-seriado, que se referem à mudança de comportamento de Amâncio. Desse modo, a informação adicional contesta o registro feito na coluna cinco, quando é citado que: "Os estudos! Os estudos eram a aza negra de sua vida", tendo em vista que na coluna seis, Amâncio: "Todavia, desde a visita do negociante, principiou a freqüentar as aulas com mais assiduidade e a reter mais na memória o que lia nos compêndios".

No padrão narrativo do romance-seriado, o jantar, oferecido por Campos, para comemorar o aniversário de casamento, caracteriza-se como um "índice energético". Essa técnica propicia uma estilização cronotópica, ao mesmo tempo em que registra índices de oralidade como elementos de inversão. Esse último aspecto pode ser evidenciado, quando, em diálogo estabelecido com o protagonista, Carlotinha [irmã de Hortênsia] revela que Amâncio "seria muito bem recebido. Que aparecesse um domingo sim, para jantar, alguém se interessava por essas visitas”. Em dedução, Amâncio conclui que esse "alguém" seria Hortênsia. Esse jantar também estabelece uma quebra do fluxo narrativo, ocasionando interrupção do relato dos efeitos que a leitura das duas cartas haviam causado em Amâncio.

Esta seqüência está organizada em sete colunas, quando grande parte dos segmentos apresenta seis divisões.

\subsubsection{Quarta seqüência: 09 de maio (36)}

Coluna 01 - "Pelo caminho de casa, o Coqueiro não se fartou de elogiar as boas maneiras e a franqueza do Campos; falou respeitosamente da amabilidade de Hortênsia, disse que Ihes havia de fazer uma visita em companhia da mulher e de Amelinha”.

Coluna 02 - "A idéia de que Lúcia estava ali perto a quatro ou cinco passos, mas inteiramente fora de seu alcance o torturava como uma injustiça clamorosa erguida contra o seu amor".

Coluna 03 - "Como podia levar a sério agora a casa de Mme. Brizard?"

Coluna 04 - "Não se pode levantar da cama no dia seguinte". "Mas a febre retrocedeu depois do almoço". 
Coluna 05 - "Amelinha revelava-se extremamente solícita. "Ele, coitado, parecia cada vez pior. Ardiam-Ihe os olhos desabridamente; o hálito queimava; não podia suportar o cheiro do fumo e queixava-se de muita sede e comichão pelo corpo".

Coluna 06 - “- Eu te amo! Eu te amo! dizia ele”.

Final com ganho: "Lúcia, também não deu mais palavra e, logo depois saiu muito enfiada".

\subsubsection{Técnicas básicas do padrão narrativo do romance-seriado}

Diferente do que ocorre na variante em livro, o início desta seqüência elucida o diálogo interior e a reflexão do protagonista, ao mesmo tempo em que destaca o fato de Amâncio ignorar as recomendações de Coqueiro:

E terminou dando ao colega conselhos referentes aos interesses do estudo, ao modo como se devia conduzir na sociedade, como deveria evitar os mil perigos da corte e a atitude que the convinha tomar em certas determinadas conjunturas.

Amâncio ouvia-o distraidamente; já o aborreciam tantos conselhos.

Este solilóquio, com marcas de oralidade do romance-seriado, expressa a vontade que Amâncio tinha de dar um basta àquelas sugestões: "- Ora bolas! todos o queriam guiar!"

Amâncio queria viver livremente e viver aventuras e a idéia de que Lúcia estava tão perto não o deixava dormir. O livro não preserva as impressões que Amâncio levou do jantar oferecido por Campos, nem mesmo o repúdio que sentia pelo anfitrião, mas conserva as intenções que o personagem tem de conquistar Lúcia, também moradora da casa de pensão de Coqueiro.

A inquietude de Amâncio retoma a técnica narrativa que focaliza os "heróis que atuam para conquistar uma mulher ou uma boa posição social” (RIBEIRO, 1998, p. 44-46). Essa técnica narrativa pode ser observada, parcialmente, neste excerto retirado da coluna dois: "A idéia de que Lúcia estava ali perto a quatro ou cinco passos, mas inteiramente fora de seu alcance o torturava como uma injustiça clamorosa erguida contra o seu amor [livro: o indispunha como se fosse uma pirraça levantada com o fim único de o afligir]". Contudo, enquanto Amâncio pretende aventurar-se com Lúcia, ela queria dar um golpe para abandonar a 
"situação social insatisfatória", e esta é mais uma técnica característica no padrão narrativo do romance-seriado.

A técnica da "utilização do acaso como ponto de convergência entre alguns acontecimentos da narração" (RIBEIRO, 1998, p. 44-46) é utilizada na terceira coluna, quando Amâncio flagra mais uma vez um dos hóspedes da casa de pensão receber visita íntima, o que leva o estudante a pensar: "Como podia levar a sério agora a casa de Mme. Brizard?"

No entanto, quando Amâncio desconfia que Lúcia podia estar tendo um caso com o piloto, sente-se traído, apesar de tê-la tido apenas nos pensamentos. Esse conteúdo que somente existiu no romance-seriado, coluna três, revela particularidades dos tormentos vividos pelo protagonista: "Mas a idéia de que Lúcia prestava atenção ao piloto o revoltava, porque Amâncio sentia as pontas de uma traição picarem-Ihe a dignidade como se entre ele e a mulher do Pereira houvesse algum pacto inviolável". Depois disso, Amâncio ficou doente, repetindo a reação das heroínas românticas.

A "estética divergente e centrífuga" caracteriza-se pela exploração de uma multiplicidade de pontos de interesse na intriga e que, de repente, passa a convergir a um único ponto, a doença de Amâncio. Esse "acaso" possibilita estes dois acontecimentos inesperados:

Coluna 05:

Amelinha revelava-se extremamente solícita. Andava no bico dos pés, a borboletear pelo quarto, arrumando os livros sobre a mesa, apanhando a roupa espalhada pelo chão, acudindo a qualquer movimento do estudante, que dormia entanguecido de baixo dos lençóis.

Coluna 06:

Mas, quando Amélia saiu e desceu ao primeiro andar, ele tomou rapidamente as mãos da outra e cobriu-as de beijos que a febre tornava mais ardentes e mais queimosos. "- Eu te amo! Eu te amo! dizia ele.

O último parágrafo apresenta a técnica narrativa do "corte com gancho no final de segmento", instaurando suspense ao texto que se revelava lentamente aos leitores. 


\subsubsection{Quinta seqüência: 11 de maio (37)}

Coluna 01 - "À noite apresentou-se o Campos, a quem de passagem o Coqueiro prevenira dos incômodos de Amâncio. Trazia um médico consigo". "Daquela forma, a casa em breve transformava-se num hospital!"

Coluna 02 - "Depois da cena violenta da sala de visitas, a pobre criatura se quedara mais apreensiva e mais triste".

Coluna 03 - "Amâncio desejava unicamente que o Campos procurasse descobrir onde andava o Sabino, que agora Ihe fazia muita falta".

Coluna 04 - "Mme. Brizard, o Coqueiro e Amelinha não desamparam o quarto do doente até mais de meia-noite".

Coluna 05 - "E todos, com grande espanto, convenceram-se de que o homem [Paula Mendes] estava em efeito ébrio [...]".

Coluna 06 - "Pelas três horas da madrugada [Livro: por volta das quatro da madrugada], Amâncio sentiu passarem-lhe brandamente a mão pela testa, e despertou estremunhado".

Final: "Um candeeiro de azeite derramava no quarto uma luz duvidosa e trêmula. Tudo era silêncio e quietação".

\subsubsection{Técnicas básicas do padrão narrativo do romance-seriado}

A primeira coluna desta seqüência estabelece um gancho com a carta escrita pelo pai de Amâncio, na medida em que Campos se via responsável pelo jovem maranhense. Essa relação de responsabilidade e comprometimento também é constatada na coluna três:

Campos agradeceu por si e pelo seu recomendado tanta delicadeza e tanta boa vontade; recomendou que não poupassem despesas com a moléstia, dessem ao doente do melhor e do mais caro e quando porventura precisassem de alguma coisa mandassem imediatamente à rua Direita, que ele lá estava prontamente para atender a qualquer reclamação.

Os excertos retirados das colunas um e dois retomam a técnica de "conduzir 
para trás". Além disso, esses exemplos apresentam certa carga de humor. $\mathrm{Na}$ coluna 01, Catarina, que há alguns dias tinha iniciado um motim de madrugada, agora apresenta comentários maldosos sobre a casa de pensão:

Daquela forma, a casa em breve transformava-se num hospital! Já lá tinham um tísico, que à noite não deixava ninguém dormir com o gogo: agora era um bexiguento; amanhã seria a febre amarela e depois a lepra! Arre! Em chegando o marido [Paulo Mendes] havia de mostrar o que faria!

A segunda coluna retoma algumas informações sobre a crise histérica que Nini havia sofrido na sala de visitas para então informar, comicamente, como a cunhada de Coqueiro reagia ao ouvir conversas sobre a enfermidade de Amâncio. Embora existisse grande alvoroço "[...] Nini, que estava desde às cinco horas estendida em uma cadeira ao canto da varanda, com um lenço amarrado na cabeça, os escutava silenciosamente, sem mexer os olhos".

Nas colunas quatro é cinco também há muita comicidade por trás deste repertório semântico:

O Melinho, a pérola do n. 9 , também aparecera; e o Piloto, quando soube, ainda na porta da rua, que havia um bexigoso no segundo andar, fez uma careta, benzeu-se comicamente, e voltou pelo mesmo caminho em que viera, afetando trejeitos exagerado de medo.

O corte com ganho instaura suspense em torno do que o enfermo e Lúcia conversariam, pois da última vez Amâncio havia dito que a amava. O último parágrafo revela a atmosfera que os envolvia, a qual também podia refletir seus sentimentos: "Um candeeiro de azeite derramava no quarto a sua meia claridade trêmula e duvidosa. Era tudo silêncio e quietação".

\subsubsection{Sexta seqüência: 13 de maio (38)}

Coluna 01 - "- Lúcia! disse ele, mal acordado, tentando passar-Ihe um braço na cintura". "- Pchit! Fez a mulher do Pereira com o dedo nos lábios - Não faça rumor".

Coluna 02 - "- Ao menos um beijinho... pediu ele".

Coluna 03 - "Mais incomodado com a sua ausência do que com a minha moléstia... respondeu o moço [a Lúcia], fazendo um ar infeliz". "Lúcia sorriu e estendeu-Ihe a 
mão, que ele beijou avidamente, ficando depois a examiná-la, como se contemplasse uma obra de arte".

Coluna 04 - "Coqueiro, que chegou logo depois, deu logo fé de que Lúcia acabava de estar ali, mas não deixou transparecer a sua contrariedade".

Coluna 05 - "Sirigaita! Gritou Coqueiro, depois de uma pausa, batendo sobre a cômoda - Bem desconfiava eu!... Acredita, Loló, que desde a chegada do Amâncio, tive cá um palpite de que aquela mulher seria um estorvo para os nossos projetos!" [em destaque conteúdo que somente existiu no romance-seriado].

Coluna 06 - "E, voltando-se nos projetos a respeito de Amâncio: - Uma ocasião tão boa para a Amelinha cativá-lo!... E lembrar-se aquele espantalho [livro: se o diabo da intrusa] de atravessar-Ihe no caminho [livro: não se metesse entre eles], justamente no melhor da coisa! Ah! peste!"

Coluna 07 - "Lembra-te de que o Amâncio é um bobo [livro, p. 110: não inventou a pólvora] e será muito capaz de deixar-se visgar por aquela lambisgóia!". "Mme. Brizard hesitava".

Final: llegível.

\subsubsection{Técnicas básicas do padrão narrativo do romance-seriado}

A primeira técnica da narrativa folhetinesca é evidenciada no primeiro parágrafo, quando Amâncio, pela primeira vez, tem um contato físico com Lúcia. Segundo Ribeiro (1998, p. 44-46), esse recurso consiste no emprego de "inícios de histórias impressionantes e sensacionalistas que provocam o interesse do leitor". De um lado, as colunas dois e três apresentam a técnica "de priorizar a ação dos personagens como unidade narrativa aglutinadora para o desenvolvimento da história", o que pode ser destacado a partir das revelações que Lúcia faz ao estudante, com a finalidade de alertá-lo do plano armado por Coqueiro. Por outro lado, as três últimas colunas focalizam que os proprietários da casa de pensão tentam encontrar uma alternativa para livrarem-se de Lúcia, no intuito de deixar o caminho livre para Amélia. Esses dois movimentos geram tensão ao discurso narrativo, sobretudo pelo acúmulo de acontecimentos, bem como os dois projetos 
que têm como finalidade para fazer do casamento um trampolim para a projeção social.

As ideologias exploradas por intermédio dos projetos matrimoniais são componentes importantes para o desdobramento da intriga de Casa de Pensão e o desenvolvimento da história. No entanto, enquanto os planos traçados por Coqueiro e Lúcia estão diretamente relacionados à exploração da temática da "vida criminosa e miserável: o poder dado àquele que é mais forte, mais hábil, mais audaz", Amâncio, por sua vez, representa a fraqueza e a vulnerabilidade, que se tornam ainda mais acentuadas quando o protagonista sofre com a catapora, popularmente conhecida como bexiga.

Tanto a conversa de Amâncio com Lúcia, quanto aquela entre Coqueiro e Mme. Brizard apresentam "abundância de diálogos" (RIBEIRO, 1998, p. 44-46), como forma de revelar traços de oralidade, pela reprodução direta do discurso dos personagens.

Como o final deste segmento está ilegível, não será possível avaliar como ocorreu seu corte na sétima coluna.

\subsubsection{Sétima seqüência: 16 de maio (39)}

Coluna 01 - "O Pereira levanta-se da mesa do jantar e, seguindo o costume encaminhava-se tropegamente em busca da sua preguiçosa, quando o Coqueiro, interpondo-se-Ihe no caminho, meteu-lhe na mão uma folha de papel dobrada sobre o comprido, e disse-Ihe em tom seguro e trescalado de urgências: É uma nova continha de suas despesas" [em destaque conteúdo que somente existiu no romance-seriado]".

Coluna 02 - "A mulher leu a conta inteira, depois dobrou-a em silêncio e guardou-a no bolso".

Coluna 03 - “- Não me amole! tartamudeou ele, sem voltar o rosto. Lúcia, que já se não podia conter, saltou-Ihe ao gasganete e encheu-lhe a cara de bofetões".

Coluna 04 - "Pereira vestiu-se demoradamente, sempre abrir a boca, depois seguiu para o primeiro andar, devagarinho, no seu passo miúdo, os braços a sacudirem num movimento pendular, como que despregados do troco". 
Coluna 05 - "Pereira explicou como tinha gasto o dinheiro. Não fora culpa sua Passara por uma confeitaria na rua do Ouvidor... alguns amigos o chamaram e, ofereceram-lhe cerveja e doces. Aceitou, mas depois os $\left(\ldots{ }^{24}\right)$ foram-se embora, e ele teve de pagar".

Coluna 06 - "Amâncio, muito desvigorizado com a moléstia, sentia destecerem-seIhe interiormente os lúbricos impulsos, que a princípio o atraía para ela, e dera lugar a uma simpatia tranqüila e doce, como só experimentara ao lado de sua mãe”.

Final: "Amâncio, às vezes, já se fazia mais doente e mais necessitado de cuidados, só para gozar os mimos da enfermeira".

\subsubsection{Técnicas básicas do padrão narrativo do romance-seriado}

O início deste segmento retoma a temática relacionada à "vida criminosa e miserável", que confere a Coqueiro o poder de desviar do seu caminho Lúcia, hóspede de sua casa de pensão. Desse modo, a estratégia elaborada por Coqueiro Ihe confere poder para pressionar Lúcia, atingindo seu marido Pereira, vulgarmente chamado pelo narrador de palerma, e é sobre sua vagarosidade que tratam as cinco primeiras colunas.

O fato de Lúcia ser pressionada a pagar as despesas relacionadas a sua estadia na casa de pensão, quando não previa essa abordagem de Coqueiro, provoca tensão à narrativa. Como ela e o marido são falidos e Pereira não se esforça para conseguir a quantia solicitada pelo proprietário da pensão, o casal se torna presa fácil diante de Coqueiro, que é caracterizado pela técnica narrativa que distingue aquele que é "mais forte, mais hábil, mais audaz".

O narrador faz uso das técnicas de "conduzir para trás" e "didatismo narrativo" para retomar a conversa entre Amâncio e Coqueiro, quando o pensionista cedeu seu gabinete no primeiro andar para o guarda-livros em troca de um quarto no segundo andar. Esse acontecimento é retomado quando, na quinta coluna, Coqueiro chega à conclusão de que a mudança repentina de Amâncio para o segundo andar foi motivada por Lúcia, a quem Coqueiro chama de velhaca.

\footnotetext{
${ }^{24}$ Ilegível.
} 
Este segmento é permeado por "Lances teatrais abundantes com bruscas mudanças inesperadas nos episódios: propósito de despertar o interesse do leitor sem despertar o seu espírito crítico". Primeiramente é apresentada uma estilização de Pereira, que revela o porquê desse personagem ter dificuldade para tomar qualquer tipo de atitude, o que o torna um ser vegetativo, incapaz, conferindo-lhe inércia física e moral. Posteriormente, assistimos à atuação de Amélia, instruída para conquistar Amâncio, que "muito desvigorizado com a moléstia, sentia desteceremse-lhe interiormente os lúbricos impulsos, que a princípio o atraía para ela, e dera lugar a uma simpatia tranqüila e doce, como só experimentara ao lado de sua mãe".

Se, de um lado temos a fraqueza de Amâncio, do outro encontramos Amélia, caracterizada com uma espécie de heroína nesta etapa do romance, devido ao fato de ser descrita com "traços de pureza, honestidade e desinteresse". A partir do emprego desta técnica narrativa a aproximação dos dois personagens é facilitada, pois Amâncio: "la-se aos poucos familiarizando com aquela criatura branca e ainda tão nova, que Ihe enchia o quarto com o frescor balsâmico de sua virgindade e rociava-lhe os sentidos com a mimalhice trafega de sua ternura".

Ao servir canja para Amâncio, Amélia o tratava como um neném. A irmã de Coqueiro fazia "estalinhos de língua, dizia e repetia que tudo estava muito gostoso". Amâncio, por sua vez: "já se fazia mais doente e mais necessitado de cuidados, só para gozar os mimos da enfermeira". A esta última citação é aplicada a técnica

narrativa de "corte com gancho", que estimula a curiosidade do leitor para o desdobramento da história.

\subsection{Capítulo XI - um segmento}

\subsubsection{Primeira seqüência: 22 de maio (40)}

Coluna 01 - "Dias depois, o médico declarou que Amâncio estava livre do maior perigo". "Logo que abandonou a cama, queixou-se de que sentia dores reumáticas na caixa do peito e nas articulações da perna direita".

Coluna 02 - "Nunca mais Ihe foi possível [a Lúcia] até aí fazer uma ou outra visita noturna ao doente [Amâncio]". 
Coluna 03 - "- Pois não percebes que toda esta gente quer fazer de ti uma propriedade sua; que esta gente te considera um tesouro precioso e teme que lho furtem?" “- Não! Não percebi até agora nada disso!.”... “Não seja hipócrita!... acudiu a outra".

Coluna 04 - "-Se me amasses, já mo terias dado provas. - Provas?" "Não acredito nesse amor medroso e comodista que se arreceia a tudo [...]".

Coluna 05 - “- Amor é o que sinto por ti, entendes?!”

Coluna 06 - "- Se é verdade que me queres ter, arranca-me das mãos de meu marido e leva-me para onde bem quiseres, faze de mim o que entenderes!".

Final:

"Entretanto, acrescentou ela, logo que se convenceu de que Amâncio não queria cair no laço - E no entanto tenho de abafar todos os meus sentimentos, tenho de calcar todos os meus desejos, porque amanhã nos separamos.

Amâncio ergueu-se, espantado.

- Como nos separamos?...interrogou ele".

\subsubsection{Técnicas básicas do padrão narrativo do romance-seriado}

O início desta seqüência não estabelece continuidade com a anterior, que focalizava a aproximação entre Amélia e Amâncio, no entanto, marca uma nova linha de ação à narrativa. Quando Amâncio já estava curado das bexigas, surge outro imprevisto. A técnica da "utilização do acaso como ponto de convergência entre alguns acontecimentos da narração" (RIBEIRO, 1998, p. 44-46) é empregada para analisar esse acontecimento súbito: "Logo que abandonou a cama, queixou-se de que sentia dores reumáticas na caixa do peito e nas articulações da perna direita".

A apresentação da segunda enfermidade é realizada a partir da técnica folhetinesca do "didatismo narrativo", por retomar episódios interrompidos por outras ações. O reumatismo sofrido por Amâncio nos remete ao fato de sua ama-de-leite ter problemas de saúde, o que pode justificar a advertência do médico, no segmento do dia 09 de março: “- Esta mulher tem reuma no sangue, dizia ele, e a criança pode 
vir a sofrer no futuro". A voz do médico é retomada pelo narrador na medida em que se pode concluir que a previsão do doutor se confirmava. Então, o narrador aplica a técnica folhetinesca de "conduzir para trás" (RIBEIRO, 1996, p. 45) à primeira coluna deste segmento, com a dedução de que: "Era o sangue de sua ama-de-leite que

principiava a rabear. Bem dizia outrora o médico a seu pai, quando este a encarregou de amamentar o filho".

Como esta seqüência é a última a que tivemos acesso, percebemos que são inseridas novas "Situações persecutórias no desenvolvimento da intriga". Nas cinco colunas finais deste segmento, a voz narrativa está centralizada em Lúcia, que procura formas para continuar perseguindo seu alvo, apesar de sentir-se acuada por Coqueiro.

Lúcia esperou um pequeno descuido do proprietário da casa de pensão para voltar a fazer uma visita noturna a Amâncio, no momento em que ele lia um volume do Alencar. A oportunidade de estar diante do estudante fez com que Lúcia se expusesse ao máximo. Primeiramente, a mulher de Pereira tenta abrir os olhos do maranhense e denunciar o plano que Coqueiro tinha para tomar sua fortuna, fazendo-o casar com Amelinha. Posteriormente, expressa seus sentimentos a Amâncio.

No final desta seqüência, ocorre um "lance teatral", atribuindo suspense à trama de Casa de Pensão, que seria publicada na íntegra um ano depois deste corte. Lúcia exige que o estudante Ihe dê uma prova de amor: "Entretanto, acrescentou ela, logo que se convenceu de que Amâncio não queria cair no laço - $E$ no entanto tenho de abafar todos os meus sentimentos, tenho de calcar todos os meus desejos, porque amanhã nos separamos".

Os últimos parágrafos evidenciam a presença da técnica folhetinesca de "Finais de histórias com desfechos inconsistentes", pois, diante da revelação de Lúcia, “Amâncio ergueu-se, espantado. - Como nos separamos?...interrogou ele”.

\subsection{Considerações adicionais}

Na nota antes de principiar, publicada na véspera do lançamento da primeira seqüência do romance-seriado, o próprio título Casa de Pensão desperta atenção, 
principalmente, após ter sido associado a acontecimentos que podem estar relacionados ao cotidiano desses estabelecimentos. De acordo com José Alcides Ribeiro (2000, p. 166), esta é uma "técnica folhetinesca de colocar títulos atraentes" para despertar curiosidade, pela carga referencial ligada àquele nome que designa uma residência ocupada por indivíduos, que muitas vezes não têm nenhum tipo de ligação. A familiaridade desse título pode ter possibilitado uma correspondência com o litígio originado em uma casa de pensão, sete anos antes da publicação do romance-seriado homônimo.

No decorrer da narrativa, as ações fluem em função do tempo, os personagens assumem papéis distintos dos iniciais, assim como se transferem de espaço a partir de elementos determinantes pelo meio ou pela circunstância. É assim que se analisa a chegada de Amâncio, sua hospedagem no Hotel Coroa de Ouro, a temporada na casa de Campos e, por último, a mudança para a casa de pensão. Este último espaço é o cenário das principais ações da narrativa, sobretudo por aproximar Amâncio e Amélia e garantir intimidade a Coqueiro, que se vê no direito de tentar dirigir a vida do hóspede e estimular seu envolvimento com a "Amelinha", a "jovem indefesa". Tudo isso caracteriza a técnica da "regra das três multiplicidades de tempo, de lugar e de ação: dilatação dos elementos narrativos de tempo, de lugar e de ação dos personagens no desenvolvimento da intriga do romance". Como marca da oralidade, grande parte das seqüências apresenta "abundância de diálogos".

O conjunto de seqüências do romance-seriado revela a habilidade com que Aluísio utilizava a técnica de "priorizar a ação dos personagens como unidade narrativa aglutinadora para o desenvolvimento da história", porque o corte realizado no quadragésimo segmento instaura um mistério sobre o desenvolvimento do discurso ficcional de Casa de Pensão. Os leitores dessa variante precisariam aguardar a publicação da nova versão, para saberem qual das três roubaria o coração do estudante, Hortênsia, Amélia ou Lúcia; ou, ainda, se alguém realmente o convenceria do casamento. 


\section{TÉCNICAS DE ROMANCE-SERIADO NA PRIMEIRA VERSÃO EM LIVRO}

Após a análise detalhada do processo de produção do romance-seriado, passaremos à análise de três seqüências representativas da parte restante publicada diretamente em livro, no ano seguinte à interrupção da publicação seriada. Destacamos que, na publicação destinada ao jornal, a história foi interrompida no Capítulo XI, o qual corresponde ao Capítulo XII dos XXII que totalizam a versão em livro, lançado por Faro \& Lino Editores, no ano de $1884^{25}$.

Como este capítulo investiga as técnicas de romance-seriado na primeira versão em livro, será empregado o procedimento analítico realizado por José Alcides Ribeiro (1996, p. 94 et seq.) sobre A Narrativa de Arthur G. Pym. Essa escolha se justifica porque a parte final da obra foi concebida para ser publicada diretamente em livro, o que coincide com o processo de publicação adotado no romance cotejado nesta investigação e, por isso, oferece-nos parâmetros para a análise aqui desenvolvida.

Para atingirmos o objetivo destacado, pretendemos apresentar as principais seqüências dos núcleos representativos do conjunto que compõe a diegese, ao mesmo tempo em que procuraremos verificar as técnicas narrativas utilizadas nos últimos capítulos do livro. Adotamos a denominação de núcleos para a reunião de alguns dos principais temas que envolvem o destino dos personagens principais no desenvolvimento da intriga, no entanto, como essas ações estão relacionadas exclusivamente aos objetivos de interesse do processo investigativo, não realizaremos uma análise aprofundada de todos os elementos que compõem a narrativa.

Conforme aludido acima, como esta pesquisa tem como foco a verificação da possível variação de perspectiva em decorrência da mudança de meio de difusão de Casa de Pensão, este processo investigativo procura descortinar os meandros da escrita do romance, no intuito de entender a lógica da organização narrativa, assim como as técnicas empregadas na vertente em livro. Para tanto, selecionamos seqüências de um núcleo que dá continuidade ao desenvolvimento do enredo e dois

${ }^{25}$ Ressaltamos que, como a edição de Casa de Pensão lançada pela Ática, em 1977, apresenta fidedignidade textual quando comparada com a versão de 1884, limitar-nos-emos a informar os números das páginas da edição do texto atualizado. 
grandes núcleos de intriga do romance, que se detêm à focalização de conflitos de interesses. O primeiro núcleo retoma ações interrompidas com o corte e conseqüente interrupção da publicação do romance-seriado, com o desfecho do romance entre Amâncio e Lúcia, a oponente de Amélia e dos planos de Coqueiro. $O$ segundo compreende as estratégias articuladas por Coqueiro e pelas personagens a ele agregadas. O terceiro abrange as ações relacionadas ao personagem Amâncio e sua reificação.

\subsection{Três núcleos narrativos adicionais}

\subsubsection{Primeiro núcleo: Lúcia}

A linha da trama que envolve os planos aplicados por Lúcia para a conquista de seu alvo, Amâncio, tem continuidade na versão em livro, no Capítulo XII. O conteúdo da última seqüência foi interrompido quando Lúcia utilizava-se de diversos artifícios para conquistar Amâncio. A continuidade de diálogos entre os amantes é uma das marcas da técnica da narrativa do romance-seriado, conforme destacamos a seguir: "- É porque não me amas, disse a ilustrada senhora, abaixando os olhos. - Se te amo, minha vida! Se te amo!... E ameigava-a, procurando beijá-la". Percebendo a resistência de Lúcia, Amâncio conclui que: "certas mulheres, quando se negam, estão recuando para melhor armar o salto sobre a presa" (CASA DE PENSÃO, 1977, p. 119).

Há um "corte no desenvolvimento da história" e "diálogos abundantes" quando uma nova direção se aproxima ao desenvolvimento da trama. A partir do momento em que Coqueiro revela a Amâncio que Lúcia havia mentido para fisgar o maranhense, a mulher de Pereira revela as intenções da interesseira:

- Casada o quê!...Da missa não sabes nem a metade!

- Então ela não é casada com o Pereira?...

- Nunca o foi! Com ele, nem com pessoa alguma! Conheço até a mulher do Pereira, a legítima, - uma velhusca, de óculos, gorda, com um olho agachado, cheio d‘água. Mora na Rua da Pedreira (CP, 1977, p. 120). 
A técnica de "priorizar a ação dos personagens como unidade narrativa aglutinadora para o desenvolvimento da história" surge quando Amâncio vai ao encontro de Lúcia, que, algum tempo depois da conversa com Coqueiro, desmascara a interesseira. No final do Capítulo XIV, há o emprego da técnica do "didatismo narrativo", com a retomada do jogada feita por Coqueiro, no final do Capítulo XII, e seu êxito dois capítulos depois. Amâncio tenta até mesmo de violência para seduzir Lúcia, que se esquiva com o pretexto de não poder trair o marido, no entanto, o nortista revela que já sabe que ela não é casada e desmascara sua dissimulação. A partir de então, o caminho fica livre para Amélia, ao passo que Lúcia nunca mais tornaria a ameaçar os planos de Coqueiro e da irmã. A partir desse desenlace, a trama direciona-se, então, para outros pontos.

\subsubsection{Segundo núcleo: Coqueiro e personagens a ele agregadas}

Na medida em que ocorre a dilatação do espaço, há a expansão dos projetos traçados por Coqueiro, orientados por Mme. Brizard e aplicados por Amélia. Da Rua do Rezende, onde Amâncio teve o primeiro contato com a família de Coqueiro, a versão em livro acrescenta dois novos espaços para a casa de pensão. A ampliação espacial contribui para que a atividade-fim perca suas características de ambiente público e passa a se tornar privado.

A técnica do romance-seriado do "acaso como ponto de convergência entre alguns acontecimentos da narração" está presente em duas situações que impulsionam a transferência de endereço dos moradores da casa de pensão. $O$ primeiro devia-se ao aconselhamento dado pelo médico de Amâncio de que seria melhor mudar-se para um lugar que favorecesse o restabelecimento de sua saúde, como Santa Teresa, por exemplo. O segundo está relacionado a um grave acidente que envolveu a personagem Nini, quando a filha de Mme. Brizard estava indo visitar Amâncio e, perdendo o equilíbrio no "patamar da maldita escada", rolou vinte degraus, partindo a cabeça em dois lugares:

Supunham, todavia, que amanhecesse morta. Foi o contrário: Nini melhorou muito de seus antigos padecimentos e apresentou uma inesperada lucidez de idéias, como há muito não possuía. - O choque fizera-lhe bem e não menos o sangue que derramou da cabeça, afiançou o médico (CP, 1977, p. 126). 
Como a melhora de Nini estava condicionada a distância do enfermo, um encontro que Amâncio não pode evitar deixou Nini em tal excitação nervosa, que o médico da histérica proibiu que a consentissem fora do quarto. Ficou presa desde esse dia.

No final do Capítulo XIII, as orientações médicas e os conflitos latentes na casa de pensão estabelecem grande importância para o desenvolvimento da principal intriga do romance. Quando Amâncio pensa em mudar-se da casa de Mme. Brizard, a irmã de Coqueiro percebe que isso significa uma ameaça aos planos idealizados pelo irmão, o que exige dela atitudes que impeçam o egresso de Amâncio:

Amélia não respondeu logo, mas depois, levantando a cabeça, que the havia pousado no colo, exclamou entre soluços angustiados: - Não! não! não hás de ir! peço-te que não vás!

O provinciano quis saber por quê.

- Eu te amo! disse ela, escondendo de novo o rosto. - Eu te amo e não posso me separar de ti! Vejo a sua indiferença ! percebo que me detesta, mas que hei de eu fazer?! Adoro-te, meu amor!

- Ah! se eu não estivesse tão doente!...suspirou Amâncio (CP, 1977, p. 127).

O início do Capítulo XIV insere um acaso que seria decisivo para a saída de Amâncio daquela casa de pensão: "O tísico do $\mathrm{n}^{\circ} 7$ há dias esperava o seu momento de morrer, estendido na cama, os olhos cravados no ar, a boca muito aberta, porque já lhe ia faltando o fôlego" ${ }^{26}$. Nos últimos momentos de vida, foi até o quarto de Amâncio e acabou morrendo na frente do estudante. Depois disso, Amâncio declarou positivamente que não estava disposto a ficar na casa de pensão nem mais um dia, por isso, mudaram-se, no dia seguinte, para Santa Teresa. Por outro lado, os argumentos do médico venceram os escrúpulos da francesa e Nini foi internada na casa de saúde do Dr. Eiras.

O fato é que, depois da morte do tísico, Amâncio tinha sua saúde ainda mais abalada, quase que não podia mexer com as pernas. Por isso, o cômodo que lhe destinaram na nova casa era o mais espaçoso e arejado. Os cuidados também não tinham limite: "Amélia, enfim, se derramava por todo ele, sem Amâncio dar por isso; invadia-o sutilmente, como um bicho que entra na carne"27.

\footnotetext{
${ }^{26} \mathrm{CP}, 1977$, p. 127.

${ }^{27}$ Ibidem, p. 133.
} 
A dilatação do espaço aproxima Amâncio e Amélia, ao mesmo tempo em que favorece o desenlace da intriga: "A nova residência punha-os muito mais juntos, muito mais unidos do que a da Rua do Resende. Os quartos eram pequenos, chegados uns dos outros; havia um sótão com escadaria para a sala de jantar. Amâncio morava aí, sozinho"28.

No início do Capítulo XV, verificamos a ação miraculosa do espaço sobre Amâncio, que um dia, depois de morar em Santa Teresa, parecia ter recuperado a saúde completamente, tanto é que naquela mesma noite teria o primeiro envolvimento carnal com Amélia: "Amâncio, que a esperava na porta, logo que a teve ao alcance da mão, puxou-a para dentro, e deu uma volta à fechadura" ${ }^{29}$. E os proprietários da casa de pensão passaram a fechar os olhos para aquele envolvimento porque sabiam que Amélia era hábil, apesar de inexperiente em matéria de sexo:

\footnotetext{
Desde esse momento, a vida em casa de Mme. Brizard tornou-se para ele uma coisa muito agradável. Ninguém mostrava desconfiar, ao menos, de suas intimidades com Amélia, pelo seu lado parecia satisfeita com o estado das coisas.

Só uma ligeira circunstância covardemente o arreceava: é que a pequena não lhe exibira amor em quarta ou quinta edição, como dizia Paiva, mas em comprometedoras primícias, com todos os cruentos requisitos de uma estréia (CP, 1977, p. 139).
}

Aos poucos, Amélia era o meio que a família encontrava para conseguir quantias significativas. Amâncio, a seu turno, não se sentia lesado por ser o provedor da maioria das despesas da nova casa, pois pensava nos benefícios tirados de tudo isso, então pensava: "Mas que valia tudo isso posto em confronto aos gozos que lhe proporcionava a deliciosa rapariga?" ${ }^{30}$. Aos poucos, Amâncio assumiu o aluguel da casa, a mensalidade da casa de saúde onde Nini fora internada; depois pagava os fornecedores, os produtos consumidos e, até mesmo, os acessórios domésticos comprados por Mme. Brizard. Quase que diariamente, Amélia entregava para Amâncio as faturas. E esse era o preço que Coqueiro cobrava pela irmã, entregue virgem àquele que tinha dinheiro para abafar todas as pressões que Amélia fazia para forçar uma união oficial.

\footnotetext{
${ }^{28}$ Ibidem, p. 133.

${ }^{29}$ ibidem, p. 139.

${ }^{30}$ Ibidem.
} 
Apesar de viverem como casados, novos acontecimentos fazem do "acaso" a ocorrência de pontos fundamentais para o desenvolvimento da intriga. O primeiro deles deveu-se à proximidade que Amâncio estava dos exames finais do primeiro ano de Medicina. O segundo foi motivado pela técnica da "dependência da intriga para o desenvolvimento da história": a morte do velho Vasconcelos e a necessidade que Amâncio via de ir ao Maranhão para consolar a mãe e cuidar do inventário significava para Amélia o risco de seu amado não voltar à Corte. Pressionado por Coqueiro e Campos, Amâncio desiste da viagem e se concentra no exame.

Ao saber que Amâncio recebeu uma grande fortuna de herança, Amelinha intensifica os pedidos de presentes: "então, já não procurava rodeios para lhe arranjar as coisas. Quando precisava de um vestido, de uma jóia, de um chapéu, dizia-lhe secamente: Deixe-me tanto, que amanhã tenho de fazer compras”" ${ }^{31}$.

Como Amâncio reluta para não ceder às novas pressões de Amélia, que exige que seu amante lhe compre um chalé no Bairro das Laranjeiras, Amélia cessa todos os mimos que antes eram destinados a Amâncio. Com isso, o relacionamento passa a ter um sentido especial para o amante, como se ele precisasse de obstáculos para valorizar as conquistas:

\begin{abstract}
Amâncio nunca lhe achou a pele tão fina, os dentes tão brancos, os olhos tão vivos e tão formosos. O pálido e ondulante pescoço da menina jamais Ihe pareceu tão misterioso: a sua garganta, macia e doce, jamais o cativara tão despoticamente. Ele, enfim, nunca a sentira tão necessária, tão indispensável.

E as cenas venturosas dos seus primeiros dias de amor lhe perpassaram vertiginosamente diante dos olhos, derramando-lhe por todo o corpo um apetite brutal que lhe fugia por entre os dedos, como um vinho precioso que se derramava (CP, 1977, p. 142).
\end{abstract}

Depois que Amélia convenceu Amâncio de que não poderia mais ficar naquela casa, afinal de contas não conseguia descansar porque precisava esperar que todos fossem dormir para entrar no quarto do amante, bem com acordar mais cedo do que todos da casa, para que a família não descobrisse aqueles encontros noturnos, o provinciano resolveu comprar o chalé. A partir de então, há uma inversão do sentido de propriedade, pois os amasiados passam a assumir a propriedade, enquanto Coqueiro e Mme. Brizard tornam-se hóspedes.

A nova casa seria o espaço ideal para a concretização das aventuras dos

\footnotetext{
${ }^{31}$ Ibidem, p. 141.
} 
amantes, além de garantir lugar para Coqueiro e Mme. Brizard. Depois desta descrição da casa, Amâncio dava toda razão à Amélia:

- Daí... esclareceu Amélia - é que nessa tal casa de que lhe falei, e que está para se vender muito em conta, há, além dos cômodos necessários para Loló e Janjão dois quartos magníficos, com entradas independentes e comunicáveis entre si por uma pequena alcova. Ora, um dos quartos dá para a sala de visitas e o outro para a sala de jantar; no caso que arranjássemos o negócio, você ficaria com um e eu ficaria com o outro, e dessa forma acabavam-se os sustos e as canseiras; porque durante o dia abriam-se as do lado de fora e fechavam-se as de dentro, mas à noite praticava-se justamente o contrário, e ficávamos nós em completa liberdade! Compreende você agora?... (CP, 1977, p. 143).

Posteriormente, à nova conquista de Amélia no mercado matrimonial, a técnica da "dependência da intriga para o desenvolvimento da história" reaparece quando Amélia encontra uma carta em que Amâncio declara seu amor à Hortênsia. Amélia sente-se ameaçada de perder as regalias e pressiona o companheiro ao casamento. Amâncio esquiva-se mais uma vez e então joga-lhe algumas verdades e julgamentos: “- Ora, filha! Nós, antes de cairmos na asneira em que caímos, não tocamos uma só vez em casamento! E, se queres que te diga com franqueza, eu até nem supunha ser o primeiro com quem tivesses relações!..."32.

Por temer ser deixada, Amélia abala as estruturas da intriga ao mostrar a Coqueiro a carta interceptada. O irmão: "abismou-se logo desde as primeiras palavras: "Minha adorada e incompreensível Hortênsia"33. E acrescenta: "- Bem. Em todo o caso, não te dês por achada! Nem uma palavra a este respeito! Precisamos dar tempo ao tempo... podes, todavia, ficar desde já tranqüila, que o que tem de ser - traz força! A justiça não se fez para os cães!..."34.

Mme. Brizard pensava diferente, pois a experiência possibilitava que a francesa soubesse que Coqueiro não tinha com o que se preocupar:

- Tolo! Bem que se vê que não conheces os homens!... Pois acredites lá que o Amâncio despreze a rapariga por ter agora um capricho pela outra?... Não sabes que a única mulher capaz de prender o homem é aquela com quem ele convive dia e noite; aquela com quem ele se habituou; aquela que já lhe conhece as fraquezas, os ridículos, as pequeninas misérias da intimidade?! Abandoná-la!... Digo-te mais: - Hortênsia é até necessária! Deixa que ele a persiga, que ele a conquiste à força de mil sacrifícios e de mil sofrimentos; deixe que ele a possua, que a tenha inteira na mão! Deixa, porque ele há de voltar, e voltar farto!... Meu amigo, paixão é fogo de palha!

\footnotetext{
${ }^{32}$ Ibidem.

33 Ibidem, p. 159.

${ }^{34}$ Ibidem, p. 160.
} 
-não dura! Nas ocasiões de fadiga e abatimento é com o amorzinho de casa que a gente se acha! E, fica então sabendo que, para um homem amar deveras uma mulher, é preciso que ele se tenha já desiludido com muitas outras! Tristes de nós, se assim não fosse! Há maridos que, ao voltar de suas correrias, apaixonam-se pelas mesmas esposas, a quem dantes só se chegavam por obrigação! (CP, 1977, p. 161-162).

Embora Coqueiro parecesse entender os conselhos da mulher, um novo conflito favorece o emprego da técnica "do fluxo alternado de tensão". Amâncio resolveu mentir que não pretendia mais viajar. Amélia compreendeu o disfarce e, "no dia seguinte, tratou de prevenir o irmão de que abrisse os olhos, se não queria ver o senhor Amâncio escapar-lhe por entre os dedos. João Coqueiro ficou de orelha em pé"35.

Coqueiro, desde a prevenção que lhe fez a irmã, não se descuidou de vigiar os passos de Amâncio. Por isso, foi fácil descobrir que ele havia comprado um bilhete de passagem para o Norte, o que lhe deu tempo para ir à casa do Dr. Teles de Moura e, seguindo as orientações do advogado, surpreendeu o fugitivo antes do embarque. Depois disso, a diegese apresenta muitas semelhanças com o desenlace da Questão Capistrano.

A técnica utilizada para descrever "os vilões da história com traços grosseiros e satânicos" é empregada para a apresentação do Dr. Teles:

Era um advogado velho, muito respeitado no foro; não pelo caráter, que o não mostrava nunca, nem pela sua ciência, que a não tinha; nem tampouco pelos seus cabelos brancos, que a estes nem ele próprio respeitava, invertendo-lhes a cor; mas sim pela sua proverbial sagacidade, pelas suas manhas de chicanista, pela sua terrível figura de raposa velha, pelos seus olhinhos irrequietos e matreiros, pelo seu nariz à bico de pássaro e pela sua boca sem lábios, donde a palavra saía seca e penetrante como uma bala (CP, 1977, p. 170).

Embora Amâncio não tivesse a proteção familiar no Rio de Janeiro, Campos havia se disposto a ajudar o maranhense a livrar-se das acusações. No entanto, quando o guarda-livros estava prestes a resolver os últimos detalhes para a contração do advogado Saldanha Marinho, um "acaso" e o "didatismo narrativo" convertem o aliado em inimigo, abalando, completamente, a imagem do provinciano. Coqueiro, em um gesto desesperado, envia ao comerciante a carta que havia sido interceptada por Amélia. A partir disso, Campos perde as forças, abala-se e toma partido do oponente de Amâncio.

\footnotetext{
${ }^{35}$ Ibidem, p. 168.
} 
Três meses depois de ter sido iniciado o processo judicial, Coqueiro chega ao tribunal para defender a honra da irmã, no entanto, Amâncio é absolvido. Um grupo enorme de rapazes, liderado pelo Paiva Rocha e pelo Simões, aguardava o colega à saída do júri, para conduzi-lo em triunfo ao Hotel Paris, onde havia à sua espera um almoço e a banda de músicos alemães.

A comemoração é contraposta pelo tema da revolta: "[...] Coqueiro se dirigia tristemente para casa. As mãos cruzadas atrás, a cabeça baixa, as sobrancelhas franzidas, com o ar trágico de um herói vencido"36. Os tormentos foram intensificados por Mme. Brizard, que passou a culpar o marido da situação miserável em que sua família ficou com a saída de Amâncio de perto deles.

O autor utiliza "didatismo narrativo" para justificar o julgamento feito por Mme. Brizard, que se fundamenta na tentativa que ela teve de impedir que Coqueiro pressionasse Amâncio a casar-se com Amélia, porque a francesa sabia muito bem como agir para prender um homem. Depois de agir contra as orientações da companheira, o inferno provocado com a absolvição de Amâncio foi maximizado pelos julgamentos da mulher:

- Mas, o culpado foste tu e tu! berrou de supetão Mme. Brizard, erguendose da cadeira com um movimento de cólera. - Se me tivesse ouvido, não ficarias agora com essa cara de asno. «Quem tudo quer, tudo perde!» Foi bem-feito, para que, de hoje em diante, preste mais atenção ao que te digo! - Agora - pega-Ihe com trapos quentes! (CP, 1977, p. 183).

Enquanto a absolvição de Amâncio calou para sempre a voz da personagem Amélia, Coqueiro passou a ser atormentado pela idéia de ter fracassado duplamente: Capistrano foi absolvido e a desonra de sua irmã foi ridicularizada publicamente. Depois de pensar em uma maneira de livrar-se daquele tormento, o antagonista "maquinalmente foi à secretária e tirou o velho revólver que fora do pai" ${ }^{37}$. A ação de pegar a arma instaura a técnica de "conduzir para trás", por se remeter aos momentos em que Lourenço, pai de Coqueiro, forçava o filho a hábitos e práticas que poderiam transformá-lo em um homem corajoso. Então:

Que estranhas recordações à vista daquela arma! daquela arma que na sua infância o fizera chorar tantas e tantas vezes!... Belos tempos que não voltam!...

[...] - Ah! bem que se recordava de tudo isso!... Parecia-lhe ouvir ainda gritar o pai, quando lhe metia à força o revólver entre os dedos. «Não! Isso

\footnotetext{
${ }^{36}$ Ibidem, p. 183.

${ }^{37}$ Ibidem, p. 185.
} 
agora hás de ter paciência! tu, ao menos, ficarás sabendo dar um tiro!» (CP, 1977, p. 185 - destaque nosso).

Coqueiro, como se previsse o início de uma vida miserável devido às crescentes humilhações sofridas, viu o ódio apoderar-se de seus pensamentos e aumentava na medida em que as provocações se intensificavam:

\begin{abstract}
Três, nada menos do que três cartas anônimas, e cada qual a mais insultuosa e mais perversa; não Ihe poupavam coisa alguma: - a vergonha real da situação, o ridículo que havia de o acompanhar para sempre, a ojeriza que o público lhe votava espontaneamente; tudo lá estava; tudo vinha descrito com uma minuciosidade cruel, e com pequeninas considerações ultrajantes, com o terrível cuidado de quem se vinga (CP, 1977, p. 185).
\end{abstract}

A intriga assume seu ponto máximo quando Coqueiro, já atormentado pela absolvição de Amâncio, pelos julgamentos de Mme. Brizard, pelas cartas anônimas, também ouve insultos enquanto tenta encontrar uma solução para livrar-se dos tormentos. Essas novas provocações são feitas por jovens que, acabando de sair da festa da vitória de Amâncio, decidem insultar Coqueiro com estes insultos: "- Dorme, dorme! É assim que fazem os sem-vergonhas de tua espécie! - vendem a irmã e põem-se a descansar no colchão que the deixou o amante!"38. A ira e o desejo de vingança têm sua culminância quando "João Coqueiro presenciara tudo aquilo, grudado a um canto da janela, mordendo os nós da mão, os olhos injetados, o sangue a saltar-lhe nas veias" ${ }^{\prime 3}$. Atormentado pelas vozes que imprimiam a felicidade de Amâncio diante de seu fracasso, Coqueiro entendeu que somente poderia acabar com todas aquelas injúrias depois de matar Amâncio e assim o fez.

A concretização do assassinato é realizada com o emprego da técnica de "lances teatrais abundantes", pois as ações que motivaram o irmão de Amélia são enfatizadas por expressões dramáticas, como se o ato fosse programado: "O Coqueiro olhou um instante para ele, sem pestanejar; depois, sacou tranqüilamente o revólver da algibeira e deu-lhe um tiro à queima-roupa. Amâncio soltou um ai". Depois de esvaziar a arma, a seqüência de tiros fez com o Coqueiro deixasse cair o revólver: "Nisto, como se acordasse de uma vertigem, saiu a correr tropeçando em tudo" 40 .

\footnotetext{
${ }^{38}$ Ibidem, p. 186.

${ }^{39}$ Ibidem, p. 187.

40 Ibidem, p. 189.
} 
Um novo "acaso" faz com que Coqueiro seja pego em flagrante. Um policial estava no hotel no momento em que o assassino de Amâncio tenta fugir: "No primeiro andar um polícia lançou-Ihe as garras aos cós das calças e o foi conduzindo à sua frente, sem Ihe dizer palavra" ${ }^{41}$. $O$ assassinato fecha o Capítulo XXI e o seguinte está centralizado no enterro do maranhense.

Ao dialogar com a ironia do destino ligada ao fato de Pereira, assassino de Capistrano, ter sido absolvido pelas mesmas pessoas que absolveram o sedutor de sua irmã, Júlia, a ficção mostra que muitos dos amigos de Amâncio passaram para o lado de Coqueiro depois da morte do maranhense. Até mesmo Paiva Rocha, que herdou todas as roupas do falecido, passou a discursar a favor do assassino de seu conterrâneo e colegas desde os tempos do Lyceu. Portanto, Coqueiro é absolvido, publicamente, pelo assassinato que se converteu em símbolo de restabelecimento da honra de sua família, embora a narrativa não relate seu julgamento judicial.

\subsubsection{Terceiro núcleo: a fragmentação de Amâncio}

Amâncio é alvo de Amélia e de Lúcia, por isso ele permeia os interesses delas em todas as ações e conflitos voltados para a realização de seus projetos, relacionados ao "mercado matrimonial". O nortista via em Hortênsia a mulher ideal. No entanto, como a mulher do Campos não Ihe dá esperança, o jovem entrega-se aos prazeres encontrados ao lado de Amélia que, por sua vez, pressionara Amâncio ao casamento. Porque a viagem de Amâncio ao Maranhão estava condicionada à formalização do compromisso, o nortista é persuadido pelo conterrâneo Paiva Rocha a viajar às escondidas, mas é pego por Coqueiro, que denuncia o sedutor da irmã, não deixando alternativas ao fugitivo, porque: "o crime era inafiançável e que por conseguinte não se podia evitar a prisão! ${ }^{42 "}$

Como os motivos que levaram Amâncio ao julgamento são semelhantes àqueles que oito anos antes da publicação do livro desencadearam no assassinato de Capistrano, tanto na ficção como no drama intitulado Questão Capistrano, os inquéritos dos estudantes são descritos como fatores que desencadearam grande comoção na sociedade carioca do período. $O$ início do relato sobre o julgamento de

\footnotetext{
${ }^{41}$ Ibidem.

42 Ibidem, p. 175.
} 
Amâncio é atraente, o que, possivelmente, tem como objetivo atrair o leitor, da mesma forma que esse drama também foi divulgado, amplamente, pelos jornais, que "começavam a explorá-lo": "E o escândalo, como um líquido derramado, ia escorrendo pelas ruas, pelos becos, penetrando por aqui e por ali, invadindo as repartições públicas, os escritórios comerciais, as redações das folhas e as casas particulares" ${ }^{43}$.

Mesmo dissolvida a casa de pensão de Mme. Brizard, a expectativa gerada em torno do julgamento do provinciano reunia muitos dos antigos pensionistas, dentre os quais destacamos o advogado Dr. Tavares, que, nesse momento, não se cansava de citar o artigo 222 do Código Criminal, para justificar a inocência do maranhense: "Amâncio nada mais fez do que desflorar mulher virgem maior de dezessete anos, o que, perante a nossa lei, não constitui crime! Por conseguinte, a prisão preventiva não devia ser efetuada!" ${ }^{4}$.

O início do Capítulo XX destaca os primeiros impactos acarretados pelo julgamento aberto contra Amâncio. O desespero de Campos fez com que o comerciante corresse até a Casa de Correção do Conde $^{45}$ para ajudá-lo no que fosse preciso. No entanto, a carta que lhe foi entregue por Coqueiro fê-lo descobrir as más invenções que o nortista hipócrita tinha sobre sua mulher: "Este surgia-Ihe agora à imaginação, como que um Satanás de mágica que deixou de fugir de repente, pelo alçapão do teatro, com a sua túnica de bom velho peregrino" 46 . Depois disso, Campos passou para o lado de Coqueiro, enquanto Hortênsia caiu de amores por Amâncio. Este último fato revela uma reação surpreendente por parte da mulher do guarda-livros, o que até parecia piada para Amâncio. Porém, esse acaso fez com que Hortênsia passasse a sentir-se culpada pelo sofrimento do provinciano, como se o sentimento dela estivesse vinculado à concretização de episódios lidos em romances e ela quisesse fazer parte daquele "lance teatral":

Amava-o agora. Seu espírito atrasado e muito brasileiro descobria nele uma vítima de fatalidades amorosas, e esse prisma romântico emprestava ao

\footnotetext{
${ }^{43}$ Ibidem, p. 176.

44 Ibidem, p. 177.

${ }^{45}$ Em 1834, Aureliano de Souza e Oliveira, futuro Visconde de Sepetiba, Ministro da Justiça, mandou lavrar a escritura da compra de uma chácara para nela construir a Casa de Correção que foi assim construída na Rua Conde D’Eu n. 277, atual Rua Frei Caneca. Lá foi construído um complexo penitenciário onde também abrigou a Casa de Detenção - onde ficavam os presos que ainda não tinham sido julgados e o Calabouço - prisão para escravos.

${ }^{46}$ Op. Cit., p. 178
} 
estudante uma irresistível simpatia de tristeza, uma deliciosa atração de desgraça (CP, 1977, p. 179).

E a mulher de Campos, que até aí não sentira dificuldade em resistir às seduções do estudante, agora, fascinada pela dramatização daquela catástrofe que o heroificava, via-o belo, indispensável, grande na sua situação especial, conhecido das mulheres, temido e odiado dos homens, vivendo na curiosidade do público, percorrendo todas as fantasias, sobressaltando todos os corações (CP, 1977, p. 180).

Uma das características marcantes do protagonista é a "temática dos vícios e amor selvagem". O desejo da conquista aguçava os sentimentos de Amâncio, portanto, tudo o que era fácil Ihe parecia suspeito ou sem sentido, conforme pode ser observado no solilóquio a seguir, em que Amâncio desmistifica a personagem Hortênsia:

- E agora?... além de perder a amizade de Campos, justamente quando mais precisava dela, havia de suportar a prosa lírica da Sra. D. Hortênsia!... "Que estava arrependida, que o adorava, que seria capaz de tudo por the dar um momento de ventura e que o esperava de braços abertos, logo que ele se achasse em liberdade" (CP, 1977, p. 180).

A exploração da "temática de aspectos da vida miserável" é explorada no momento em que Amâncio se encontra na Casa de Correção, sozinho, sem o apoio da família ou de Campos: "E chorava, o infeliz, chorava como se quisesse vingar nas lágrimas" 47 . Desafortunado, Amâncio via tudo piorar progressivamente, como se fosse perdendo todas as ilusões; a imagem de Hortênsia se desfazia e "a vida se lhe fazia mais escura e mais apertada entre as paredes da sua prisão". Então, a narrativa incorpora a técnica de "conduzir para trás" e a imagem tranqüila e doce de sua mãe vem a sua mente: "permanecia com a mesma consoladora suavidade; sempre aquela mesma carinhosa figura de cabelos brancos, aquele corpo fraco, vergado e tão mesquinho que parecia pequeno demais para sustentar tamanho amor"48.

Há uma progressão temporal no início do Capítulo XXI, com a supressão de detalhes do período em que separava Amâncio do julgamento. Primeiro o narrador revela que três meses depois de surpreendido em fuga o acusado foi absolvido, depois apresenta detalhes do processo judicial que o absolveu. De modo semelhante ao que ocorre no romance-seriado, a "estrutura sinusoidal da intriga",

\footnotetext{
${ }^{47}$ Ibidem, p. 180.

${ }^{48}$ Ibidem, p. 181.
} 
com a técnica de contar a história, provocando um fluxo alterado de tensão e distensão por meio da organização dos elementos da narrativa nas seqüências, provoca expectativa por parte do leitor e atenção diante da necessidade da organização lógica por intermédio da leitura.

Conforme apresentado anteriormente, o momento em que Coqueiro esvazia a arma em direção de seu alvo Amâncio é descrito como em um "lance teatral", com destaque para as expressões produzidas no semblante dos dois estudantes. Depois de disparados diversos tiros à queima-roupa, Coqueiro deixa o quarto de hotel onde estava o provinciano, como se estivesse acordado de uma perturbação:

\footnotetext{
Entretanto, Amâncio despertou com um novo gemido e levou ao peito as mãos que se ensoparam no sangue da ferida. Olhou em torno, à procura de alguém; mas o quarto estava abandonado.

Então, fechou novamente os olhos estremecendo, esticou o corpo - e uma palavra doce esvoaçou-lhe nos lábios entreabertos, como um fraco e lamentoso apelo de criança: - Mamãe!... E morreu (CP, 1977, p. 188).
}

O final do Capítulo XXI apresenta o "gancho" característico do romanceseriado, ou seja, a morte de Amâncio instaura um novo ponto de interesse da intriga, introduzido pelo impacto provocado pela morte do estudante que estava descansando depois de comemorar a absolvição.

\subsubsection{1 Último capítulo do romance Casa de Pensão: a reificação de Amâncio}

O último capítulo de Casa de Pensão retoma as ações vinculadas às estratégias traçadas por Coqueiro e personagens a ele agregadas, e desenvolve os últimos pontos da intriga do romance. Nessa etapa, são acrescentadas as principais ações ocorridas depois que Amâncio foi julgado por abuso sexual; o inquérito que o absolveu e sua reificação.

A morte do protagonista estimulou o sobressalto da população e de repórteres, com a formação de grandes grupos em torno do Hotel Paris. Em meio ao tumulto surgiam inúmeros comentários sobre o acontecimento, dentre eles se destacava a voz de Lambertosa, que relembrava da figura de Amâncio: "sempre distinto, sempre viajado, pronto sempre a explicar as coisas cientificamente" 49 , o que faz uma analogia ao fato de Amâncio cursar Medicina e à linguagem naturalista. A

\footnotetext{
${ }^{49}$ Ibidem, p. 189.
} 
fala do ilustre gentleman da casa de pensão da Mme. Brizard inicia a reorganização da trama, por intermédio do "didatismo narrativo" que retoma a voz dos antigos pensionistas que conviveram com Amâncio. Muitos dos antigos inquilinos de Mme. Brizard também apareceram no necrotério, como se esses personagens voltassem à cena para assistir ao desfecho da história.

Da mesma forma que ocorreu com o relato da Questão Capistrano, no momento da morte de Amâncio, toda a população só pensava na tragédia que o vitimou. Para registrar o impacto desse drama "os jornais saíam carregados de notícias e artigos sobre ele, esgotavam-se as edições da defesa e da acusação de Amâncio" ${ }^{50}$. A técnica de "priorizar a ação dos personagens com o recurso de expressão para esse fim" é enfatizada na medida em que se agravava a situação do maranhense.

Hortênsia, que para Amâncio parecia ser a única mulher que poderia ser comparada com sua mãe Ângela, passou a perder as características que lhe conferiam integridade, como se o meio e as circunstâncias tivessem corrompendo-a. A força que contribuiu para a ascensão do marido Campos se fragmenta na medida em que Hortênsia se entregava à fantasia criada depois da prisão de Amâncio. Então, "quando lhe constou o terrível desfecho daquele episódio que, na sua fantasia romântica, tomava as proporções de um poema, caiu sem sentidos e ficou prostrada na cama por uma febre violenta" ${ }^{51}$. No entanto, se por um lado Hortênsia se converteu, progressivamente, de mulher realista à romântica, por outro lado, há indícios de que se Amâncio não tivesse morrido, dificilmente se entregaria à mulher de Campos, ressaltando a característica romântica do personagem que associava a figura angelical da mãe à mulher idealizada, ou seja, na medida em que Hortênsia se tornava acessível, deixava de ser desejada.

Outra analogia estabelecida com a morte de Capistrano ocorre com a referência feita a Saldanha Marinho, defensor do paranaense e do personagem que o representa. Essa informação se remete à técnica narrativa da "verossimilhança que nunca escorrega para o irracional", ou seja, sempre há "uma explicação real para a verossimilhança dos fatos". No entanto, no momento da morte de Amâncio, o nome do advogado é citado indiretamente: "Por influência do advogado de Amâncio,

\footnotetext{
50 Ibidem.

51 Ibidem.
} 
que era político e bem relacionado, compareceram muitos figurões e até alguns homens do poder" ${ }^{\prime 2}$.

Outra característica presente neste núcleo narrativo é a retomada de espaços percorridos pelo protagonista, que no epílogo representam lugar destinado à platéia que assistiu ao funeral do maranhense. O sobressalto causado na cidade estabelece analogia com o momento em que a procissão fúnebre de Capistrano foi acompanhada por parcela significativa da população carioca. Se, por um lado, o Jornal do Comércio e a Gazeta de Notícias registraram que, aproximadamente, duas mil pessoas acompanharam o fúnebre cortejo de Capistrano, Casa de Pensão registra que na morte de Amâncio:

\begin{abstract}
O funeral atingiu dimensões gigantescas; parecia que se tratava da morte de um grande benemérito da Pátria.

Veio muita gente dos arrabaldes. De todos os cantos do Rio de Janeiro acudia povo e mais povo a ver o enterro. As ruas, os largos, por onde ele ia, ficavam acogulados de gente; os garotos grimpavam-se aos muros, escalavam as árvores, subiam às grades das chácaras; as janelas regurgitavam, como num domingo de festa.

O caixão foi carregado a pulso, coberto de coroas; no cemitério ninguém se podia mexer com a multidão que afluía. Um delírio! (CP, 1977, p. 189-190).
\end{abstract}

O diálogo com a Questão Capistrano vai além da referência ao tema, pois, o romance também registra a repercussão do acontecimento que se tornou notícia: "E no dia seguinte, descrições e mais descrições jornalísticas; necrológios, artigos fúnebres, notícias biográficas e poesias dedicadas à 'triste morte daquelas vinte primaveras"”53. Da mesma forma que Alexandre Pereira foi indiciado alguns meses depois de ter assassinado o colega da Escola Politécnica, em Casa de Pensão existe a informação de que "o fato não caiu logo no esquecimento, porque aí estava o novo processo do assassino para lhe entreter o calor, à feição de um banhomaria" 54 . O romance destaca que a notícia causava grande agitação naqueles que ainda lembravam do julgamento anterior, como se fosse seu desdobramento.

Embora a ficção não relate a sentença atribuída a Coqueiro, o "final da história tem desfecho inconsistente" ironiza o desfecho dado ao assassino de Capistrano. Enquanto o drama apresenta a inversão de perspectiva e de valores por trás da absolvição de Alexandre Pereira, vinda das mesmas pessoas que

\footnotetext{
${ }^{52}$ Ibidem.

53 Ibidem, p. 190.

${ }^{54}$ Ibidem.
} 
absolveram Capistrano, Casa de Pensão destaca os fatos que antecederam o inquérito, ironizando a volatilidade do ser humano.

Apesar de ter se revoltado contra Amâncio, Campos decide escrever para a família de Amâncio. Sem relatar o que descobrira sobre os escrúpulos do jovem maranhense, o guarda-livros apenas escreve à Ângela para comunicá-la da prisão do filho. Com efeito, ela resolveu seguir para a Corte, imediatamente, no primeiro vapor. O último episódio existente no último capítulo narra a chegada da mãe de Amâncio ao Rio de Janeiro. Pouco depois do enterro do filho, Ângela, já idosa, saltava no cais Pharoux coberta de luto, acompanhada por uma mulata, cuja voz não é registrada, e de um senhor que ela conheceu na viagem.

O desespero da mãe à procura do filho confunde-a entre a busca na direção da Rua Direita, de onde Campos havia endereçado a última carta e a Rua das Laranjeiras, endereço registrado nas cartas enviadas por Amâncio.

No momento da procura, Ângela mostrava-se "sempre inquieta, a olhar para todos os lados, como se esperasse, por um acaso feliz, descobrir Amâncio, de um momento para outro" ${ }^{55}$. É foi então que o "acaso", comumente empregado no romance-seriado, surpreende a mãe de Amâncio. Se, por um lado, o desfecho retoma o caráter mercantil atribuído ao símbolo criado em torno de Amâncio, quando registrado que no momento de julgamento do maranhense "vendia-se na rua o retrato deste em todas as posições, feitios e tamanhos; moribundo, em vida, na escola, no passeio. E tudo ia direto para os álbuns, para as paredes e para as coleções de raridades" 56 . Por outro lado, a morte estabelece o "didatismo narrativo" com a vendagem de produtos vinculados à imagem de Amâncio.

Na Rua Direita, Ângela, de repente, ficou imóvel quando identificou na vidraça de um armarinho chapéus dedicados "à Amâncio de Vasconcelos". Como não entendia o sentido da menção feita ao filho, o senhor que estava com ela precisou explicar que: "- É o título! disse. - Eles agora batizam as mercadorias com os nomes que estão na moda. Algum tenor!" Apesar de o senhor tentar convencê-la de que o nome lido poderia ser de outra pessoa:

D. Ângela fugira-lhe outra vez do braço para correr a uma nova vidraça. Eram agora bengalas e gravatas «à Amâncio de Vasconcelos» que lhe prendiam a atenção.

Acabavam de entrar na Rua do Ouvidor [...]. D. Ângela aproximou-se do retrato, correndo, e soltou logo uma exclamação:

\footnotetext{
${ }^{55}$ Ibidem, p. 191.

${ }^{56}$ Ibidem.
} 
- Mas é ele! É meu filho! o meu Amâncio!

[...] Tinha visto seu filho, representado na mesa do necrotério, com o tronco nu, o corpo em sangue.

E por debaixo, em letras garrafais:

«Amâncio de Vasconcelos, assassinado por João Coqueiro no Hotel Paris, em tantos de tal» (CP, 1977, p. 191-192).

A morte de Amâncio é caracterizada como um episódio que irá banalizar a figura do estudante. Se antes somente as pessoas mais próximas tentavam extorquir o dinheiro do nortista, a morte favorece a ampliação do conceito de alienação, como a transferência da propriedade de Amâncio àqueles que poderiam lucrar com o símbolo de drama. Quando vivo, Amâncio foi atraído para duas armadilhas que pretendiam fazer dele uma pessoa reificada - transformada numa coisa, numa simples propriedade. Por intermédio do contrato matrimonial, idealizado por Coqueiro para Amélia, e do golpe traçado por Lúcia, definiam-se os dois movimentos para que Amâncio passasse a ser propriedade daquela que o fisgasse. Enquanto a "situação social insatisfatória" das duas personagens está ligada à necessidade que elas tinham de fazer de Amâncio uma propriedade que "pudesse ser dominada pelo seu novo dono" (MESZAROS, 2006, p. 38), a síntese atribuída ao protagonista de Casa de Pensão dialoga com a teoria extraída da transformação da noção de trabalho, com a redução do ser humano em coisa e a perda de suas características edificantes.

\subsection{Considerações adicionais}

Chegamos, então, ao final do capítulo. Julgamos pertinente destacar, portanto, que a análise dos núcleos com o conteúdo restante da história demonstra que $\mathrm{o}$ autor preservou algumas das características que norteou os segmentos publicados no formato de romance-seriado, sobretudo pela continuidade no emprego de algumas técnicas do romance-seriado, como: abundância de diálogos; técnica de priorizar a ação dos personagens com o recurso de expressão para esse fim; conduzir para trás; verossimilhança que nunca escorrega para o irracional; lances teatrais; acaso como ponto de convergência entre alguns acontecimentos da narração; corte com gancho entre os capítulos; didatismo narrativo, dentre outras.

Outra particularidade interessante ao desfecho da narrativa de Casa de 
Pensão é o emprego da técnica do romance-seriado de inserir "vilões da história com traços grosseiros e satânicos", que se torna ainda mais enfática com a zoomorfização. Vendo o ser humano por intermédio de uma perspectiva biológica, os traços e atributos de alguns dos personagens recebem características animalescas. Ao focalizarmos o antagonista, percebemos que na medida em que Coqueiro se encaminha para o fracasso, é intensificada a utilização de procedimentos deformadores, utilizados para reduzir o personagem a formas animais, com simbologia ligada à fraqueza.

Como o advogado carola Teles Moura, caracterizado como uma raposa velha, não conseguiu a vitória dos interesses do seu cliente, Coqueiro entrou em um botequim para esconder-se dos risos e comentários cheios de escárnio por sua derrota. Nesse momento, inicia-se o sentimento que levará Coqueiro à vertigem, então: "uma raiva negra, um desespero surdo e profundo entraram-lhe no corpo, que nem um bando de corvos, para lhe comer a carniça do coração" 57 .

Quando chega à sua casa, Mme. Brizard o compara a um asno, por não ter seguido seus conselhos: "Se me tivesse ouvido, não ficarias agora com essa cara de asno. 'Quem tudo quer, tudo perde!"”58. A francesa ressalta o fato de "suas cabeçadas", provocadas por suas atitudes inconseqüentes iriam afetar a todos, então acrescenta: "É preciso ser muito cavalo, para ter a fortuna nas mãos e atirá-la pela janela fora! Agora é que eu quero ver! Anda! Vai arranjar hóspedes!”59.

De repente, os motivos propulsores de seu tormento são retomados, para então aflorarem de modo mais intenso e carregados de carga semântica ligada à zoomorfização do antagonista: "Não podia sossegar um minuto - era deixar-se ir consumindo pelo sofrimento, até que a dor cansasse de doer e os tais bichos negros do coração lhe comessem o último bocado de carniça" 60 . No momento em que Coqueiro pensava no fato de Amâncio ter dormido meio ano com Amélia, também ligava a popularidade do maranhense à facilidade que ele tinha para fazer novas amizades, enquanto ele se achava um infeliz, que todos evitavam, como se fosse um leproso, que via seu coração ser comido pelos "bichos negros" que o contaminavam de ódio.

\footnotetext{
${ }^{57}$ Ibidem, p. 183.

${ }^{58}$ Ibidem.

${ }^{59}$ Ibidem, p. 184.

${ }^{60}$ Ibidem.
} 
Enquanto se via atormentado pelo inferno instaurado em seus pensamentos, aproximadamente dez convidados que haviam comemorado a absolvição de Amâncio se aproximavam da casa de Coqueiro. Quando chegaram à Rua das Laranjeiras, os estudantes começaram a gritar, em fúria: “- Estás dormindo, ó Joãozinho dos camarões?! [...] - Dorme, dorme! é assim que fazem os semvergonhas de tua espécie! - Vendem a irmã e põem-se a descansar no colchão que Ihe deixou o amante!"61. Conhecida por Amélia dos camarões, por fazer as melhores espetadas de camarão do Rio de Janeiro, Coqueiro é motivo da ironia que o coloca no mesmo naipe da irmã.

Os insultos se intensificam com este grito: "- Sai, parasita!", reduzindo Coqueiro à mesma condição de organismos que vivem à custa de um hospedeiro, que nada mais é do que Amâncio e de seus bens. E continuam os insultos: "- Sai, cão! - Deixa a casa, que não é tua! - Fora! - Fora o cáften!". Depois de comparar Coqueiro a um ser sórdido, que vende sua irmã, como em um comércio de meretrizes, os estudantes passam a compará-lo com um porco. Conseqüentemente, os vizinhos não poderiam calá-los porque: "Quem mora junto ao chiqueiro sente o fedor da lama! gritou um segundo ${ }^{62 "}$.

Até mesmo no momento de assassinar Amâncio, Coqueiro é comparado a um otário: "A segunda bala já não o pilhou, mas o irmão de Amélia, abstrato, pateta, continuava a disparar os outros tiros até que a arma lhe caiu das mãos" ${ }^{\text {"63 }}$. Então, é fechado o ciclo de entorpecimento envolvendo Coqueiro, ciclo esse que teve início com os insultos iniciados à saída do tribunal, que, por sua vez, aplicou a Coqueiro a pena do fracasso.

\footnotetext{
61 Ibidem.

${ }^{62}$ Ibidem.

${ }^{63}$ Ibidem, p. 188.
} 


\section{DO ROMANCE-SERIADO AO LIVRO}

A plasticidade do discurso de Casa de Pensão é produto da plurissignificação dos discursos absorvidos e sintetizados em um gênero híbrido, que se molda às técnicas do romance-seriado e, posteriormente, recebe o formato de livro. Em menor ou maior grau, as duas publicações refletem a dimensão histórico-cultural que a concepção de gênero implica, em decorrência do caráter dialógico e social que o romance absorve. No livro, há a identificação das transformações diferenciais em termos de técnicas de criação adotadas no romance-seriado, as quais nos impulsionam à investigação do processo criativo adotado por Aluísio Azevedo na composição de Casa de Pensão. Nessa perspectiva, partimos do pressuposto de que a escrita das duas versões do romance é motivada pela dupla natureza que lhe é conferida e pelos códigos semióticos que permeiam a estrutura narrativa: notícia e referencial criativo; romance-seriado e livro; leitores e críticos; efemeridade e permanência.

No intuito de apresentar particularidades do percurso criativo de Casa de Pensão e, ao mesmo tempo, apresentar duas etapas de elaboração do conteúdo narrativo, na vertente do romance-seriado e em livro, entendemos a necessidade de aproximar a lente investigativa sobre o movimento de composição do romance focado neste estudo. As especificidades que podem definir as estratégias utilizadas por Aluísio Azevedo vão além do que se refere à adequação ao formato, pois são capazes de evidenciar em que medida o escritor também tinha consciência da necessidade de revisar o que os leitores que lhe eram contemporâneos haviam lido, para, então, lançar a história em livro para um público mais amplo.

Além de seguir uma tendência editorial em voga no segundo meado do século XIX, tanto no Brasil quanto na Europa, o romance publicado em periódico, na seção folhetim, caracteriza-se como uma espécie de prova tipográfica: modificando o texto impresso, alertando o autor sobre o possível sucesso ou fracasso que a edição em livro alcançaria. Este último aspecto pode ser evidenciado no romance-seriado Casa de Pensão - publicado, parcialmente, no jornal Folha Nova - RJ, entre março e maio de 1883 - cuja suspensão ocorreu antes mesmo da apresentação do clímax, o que nos leva a crer que o autor havia constatado o sucesso que a história atingira entre 
os leitores e críticos e, por isso, houve a redefinição da estratégia e do momento de publicação.

Com a divulgação dos segmentos suspensa, Aluísio pode se dedicar à elaboração dos demais capítulos e modificar os já escritos. Para entender como ocorreu o processo de alteração nos onze primeiros capítulos do romance-seriado, quando foram reorganizados para anteceder o texto complementar com a hipertrofia da intriga, apresentaremos algumas tipologias na tentativa de caracterizar as técnicas composicionais utilizadas na escrita de Casa de Pensão. Como todo esse discurso romanesco carrega, em menor ou maior proporção, as marcas ideológicas de quem o construiu, esta análise procura verificar em que medida o ponto de vista de Aluísio pode ter sido redefinido em função das mudanças de perspectivas do texto.

Araripe Júnior já havia antecipado, em 1884, por ocasião do surgimento da versão de Casa de Pensão em livro, que o movimento criativo do romance redefiniu a escrita do conteúdo publicado em 1883. Por acompanhar bem de perto o percurso de produção do romance em análise, o crítico revela essas impressões acerca da nova versão: "Amigo Aluísio Azevedo. - Acabo de reler a sua Casa de Pensão. Digo reler porque já a conhecia pelos fragmentos publicados na Folha Nova, que, hoje refundidos, castigados, formam o formoso livro que tenho diante dos olhos" (GAZETA DE NOTÍCIAS - RJ, 1884, ago. p. 1).

A constatação de Araripe revela que no momento em que foi publicada a segunda versão de Casa de Pensão, já eram perceptíveis as alterações realizadas pelo autor. Como as mudanças ocorridas no processo de escrita podem revelar particularidades do movimento criativo adotado por Aluísio Azevedo, selecionamos variantes representativas desse procedimento, as quais convivem com as unidades estáveis, que podem deslizar no tempo e adquirir sentidos diversos, sem, necessariamente, estarem ligados ao século XIX, afinal de contas, tanto os sentimentos humanos como o material da ficção busca na realidade a essência para compor o texto poético.

Ao conceber a obra literária em dois momentos criativos, Aluísio teve a oportunidade de revisar o que já havia escrito, tanto no papel de leitor do próprio texto, como no papel de avaliador da técnica ligada ao meio de divulgação. A habilidade exercitada na combinação de códigos semióticos atribui plasticidade à linguagem literária, que se molda em função dos meios aos quais ela se vincula por 
intermédio da publicação. Por isso, as modificações realizadas configuram-se como elementos fundamentais para a caracterização do contexto comunicativo.

\subsection{Pressupostos da análise}

Para a análise de Casa de Pensão, optamos pela seleção de variantes representativas das alterações ocorridas nas versões cotejadas, sem a pretensão de contemplar toda a diversidade presente nas duas versões que compõem o corpus desta pesquisa. O eixo que norteia as categorias selecionadas está ligado à linguagem híbrida, que se alterna entre a utilização de traços característicos da estética romântica e naturalista; a dialogia entre ficção e notícias sensacionalistas registradas por jornais cariocas de grande circulação; as representações que se moldam em indivíduos ligados à Questão Capistrano e a outras pessoas selecionadas pelo autor; a representação de um microcosmo da sociedade a partir do contexto literário comum ao tempo histórico da narrativa e outro que se perpetua pelo temas publicados no formato de livro; dentre outros aspectos apresentados no decorrer desta avaliação.

\subsection{A voz e o ponto de vista}

A escolha do tema e dos objetos de estudo sobre os quais incide esta investigação foi motivada pelo fato de se tratar de um episódio "real" que a mídia impressa acompanhou e transformou em "acontecimento" e que a ficção reapresentou como romance. Trata-se do drama notabilizado como Questão Capistrano e do romance de Aluísio Azevedo - Casa de Pensão - que retoma alguns elementos da tragédia. O romance-seriado, divulgado no jornal Folha Nova (1883), dialoga com esse assunto polêmico que abalou a sociedade carioca no ano de 1876, a partir dos relatos do Jornal do Comércio e da Gazeta de Notícias.

Para entender como a presença da dialogia e da intertextualidade pode influenciar as modificações das versões do romance, utilizamos três categorias conceituadas por Genette (1995, p. 27-30) como visão (aspecto), que se remete a 
questões de ponto de vista narrador; registro (modo), abrangendo os problemas de representação e narração (distância); e voz que designa, ao mesmo tempo, às relações entre narração e narrativa e entre narração e história. Para as finalidades propostas neste estudo, privilegiaremos as categorias voz e ponto de vista, com a finalidade de entender a construção do discurso a partir do olhar de quem o definiu e delineou.

Conforme apresentado no primeiro capítulo deste estudo, a versão projetada para o jornal corresponde a um conjunto de textos, com o registro de, praticamente, a metade dos capítulos de Casa de Pensão. Embora não saibamos qual é o número exato dos segmentos publicados no jornal Folha Nova (1883), devido às lacunas constatadas durante a análise, tivemos acesso a quarenta seqüências, que representam grande parte do conteúdo publicado em livro. A seleção de exemplos comuns às duas publicações demonstra a preocupação do escritor de estabelecer relações de sentido, progressão narrativa e temática, que encontram no contexto um elemento chave para a interpretação das vozes da narrativa e o ponto de vista impresso no discurso ficcional.

Apesar de preservar elementos característicos do padrão narrativo do romance-seriado, a mudança de formato e a ampliação do universo de leitores exigem a reestruturação da diegese, com a revisão das marcas próprias da narrativa como discurso e como história. Caso contrário, se cada unidade de sentido que integra o contexto da publicação do romance-seriado for analisada fora dele, a interpretação poderá diferenciar-se de acordo com cada leitura e a sensibilidade ao contexto. Ricoeur ressalta que "a polissemia das palavras" está relacionada "ao papel seletivo dos contextos relativamente à determinação do valor atual que adquirem as palavras numa mensagem determinada, veiculada por um locutor preciso a um ouvinte que se encontra em uma situação particular" (RICOEUR, 1990, p. 19).

Genette e Ricoeur apresentam elementos capazes de nos auxiliar a responder "quem fala" em Casa de Pensão, bem como conduzem ao elemento da narrativa voz, para distinguir de modo que respeita à questão: procuramos desvendar em que medida o ponto de vista dos personagens e do narrador orientam a perspectiva narrativa nas duas versões cotejadas. 


\subsection{Ponto de vista do narrador}

A tipologia de Casa de Pensão somente pode ser entendida diante de uma atividade interpretativa, com base em conhecimentos prévios tais como a ideologia do autor, os padrões estéticos e morais, as circunstâncias históricas presentes no grupo sociocultural contemporâneo à publicação do romance-seriado. Como a mudança de público também pode interferir no foco narrativo, e o livro traz inúmeras alterações, selecionamos alguns exemplos representativos desse processo, no intuito de criar uma tipologia das variantes, bem como de confrontar características distintivas já apresentadas separadamente.

Em contato com o texto, a atividade de leitura por analogia poderá levar à modelização ${ }^{64}$ e à formalização, com a compreensão de um recorte feito em um microcosmo carioca, o que se dá com o conhecimento perceptivo da Questão Capistrano ou de temas que se remetem ao imaginário do leitor. A poética de Aluísio demonstra sua habilidade para construir uma linguagem plástica que se alterna entre o concreto e o abstrato, o real e o imaginário, um drama e uma releitura deste. Segundo Edgard Morin (1996),

a compreensão é o conhecimento que aprende tudo aquilo de que podemos fazer uma representação concreta, ou que podemos captar de maneira imediata por analogia. Assim, a representação é compreensiva porque transmite um conhecimento no próprio ato que faz surgir uma analogia do fenômeno percebido [...] (MORIN, 1996, p. 135).

A efetividade da comunicação pelo viés do duplo requer proximidade física ou noológica (espiritual) entre os interlocutores. Edgar Morin atribui a esses mecanismos a denominação de identificação/projeção. No plano de Casa de Pensão, essas construções podem ser vistas nas relações e situações estabelecidas entre os personagens, que dialogam com fatos presentes na memória de alguns leitores. Porém, somente o conhecimento antropossocial revelará que o romance apresenta referencial jornalístico e histórico.

A efetividade da compreensão ocorre na medida em que: "comporta uma projeção (de si sobre outrem) e uma identificação (de outrem consigo)" (MORIN, 1996, p. 135-136), como se o duplo movimento de sentido unisse todos os

\footnotetext{
${ }^{64}$ Iuri Lotman define modelização como um processo pelo qual o texto utiliza diversos mecanismos semióticos para produz um modelo do mundo específico. Cf. Lotman, I. 1978, p. 76.
} 
integrantes no ato comunicativo. Portanto, esse elo de projeção - identificação que um ego alter (de personagens) se torna um alter ego com quem há uma identificação - torna possível compreender sentimentos, desejos e receios.

Nesse aspecto, compreender os conflitos que atormentam o personagem Amâncio pode substituir o conhecimento e as explicações atreladas ao seu modelo, inspirado, parcialmente, por Capistrano da Cunha.

Do mesmo modo que ocorre com a construção de alguns dos personagens, em alguns momentos da narrativa, Aluísio parece projetar-se no protagonista, ao utilizar a voz de Amâncio para expressar o sentimento de revolta guardado de seu professor Pires, no intuito de compreender as dores do seu personagem. No entanto, por trás dessa mimesis, revelam-se duas instâncias representativas, por um lado a de Aluísio que se revê criança injustiçada e que, por outro lado, continua sendo o autor.

Esta investigação procura verificar em que medida o movimento criativo revela que: a) Aluísio utilizou técnicas narrativas diferentes nos textos focados neste estudo; b) a supressão ou inserção de conteúdo teria significado primordial para o estudo desses dois gêneros, principalmente na definição do romance-seriado; c) a dialogia estabelecida entre ficção e relatos jornalísticos se alterna nas duas versões de Casa de Pensão; d) o ponto de vista do autor e as vozes narrativas se constroem em harmonia com o projeto criativo do autor.

\subsection{Tipologias anunciadas no romance-seriado}

$\mathrm{Na}$ tentativa de construir um quadro tipológico capaz de caracterizar as estratégias adotadas por Aluísio, nos dois momentos de produção do discurso ficcional de Casa de Pensão, criamos categorias representativas dos procedimentos utilizados pelo autor. Primeiramente, destacamos que o início da história é marcado pela chegada de Amâncio ao Rio de Janeiro e a descrição dos aspectos físicos do personagem. Nos seis primeiros segmentos, há a predominância de anacronismos temporais, motivados pela vertigem que Amâncio sofre durante a viagem à Corte, pela saudade que sente da mãe e de alguns de seus amores, sem deixar de

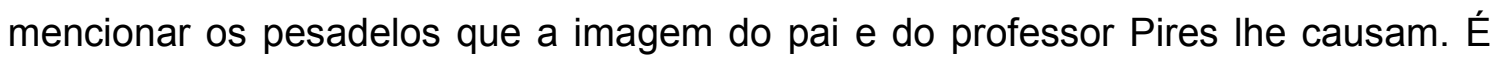


por intermédio dessas lembranças que sabemos como foi a infância do protagonista e, principalmente, como se estruturou o seu (ou a falta de) caráter.

$\mathrm{Na}$ seqüência 07 , surgem aspectos naturalistas, na relação que o personagem estabelece com o curso de Medicina. Por outro lado, os pensamentos românticos sugerem a necessidade que Amâncio sentia de viver novos amores. $O$ contato com outros personagens estabelece a organização da trama. Amâncio depara-se com um mundo repleto de pessoas interesseiras e que dissimulam falsos sentimentos a fim de explorá-lo. Sua fraqueza moral o enfraquece e ele se vê em uma casa de pensão, cercado por estranhos, sem refúgio, sem o amor materno.

Estruturas características do romance-seriado são evidenciadas com: a presença abundante de diálogos; apresentação gradativa de detalhes sobre o caráter dos personagens; suspense de episódio para episódio, o que motiva a curiosidade do leitor; a apresentação de Amâncio como um anti-herói, homem medíocre que prefere dissimular seus sentimentos para ser aceito em sociedade, e que por isso vive em constantes conflitos: ora freqüenta festas em hotéis cariocas e se entrega à boemia, ao consumo desregrado de bebidas alcoólicas e aos amores proibidos, ora participa de jantares em família, tenta estudar para as provas do curso de Medicina, mas não tem a mínima vocação para o estudo. Embora Amâncio tente conviver em dois extremos, sua fragilidade, fraqueza e inesperiência fazem com que o personagem passe por constantes crises e sofrimento e consome.

Como o significado do discurso de Casa de Pensão está atrelado ao contexto de sua produção, torna-se relevante ao seu entendimento o estudo do processamento da linguagem das duas variantes, assim como a visão que Aluísio tinha a respeito dos leitores do romance-seriado, no intuito de entender com se moldou o significado em um nível social da crítica na época. Para tanto, as variantes em negrito destacam as alterações ocorridas no movimento criativo do romance.

\subsection{Cronótopo}

O cronótopo de Casa de Pensão é configurado por uma unicidade indissociável. Podemos caracterizar o tempo como equivalente de histórico; e espaço, de social. Nessa perspectiva, tempo-espaço corresponde a históricosocial. Porém o tempo-espaço também pode ser pensado como uma refração do 
histórico-social internalizado, como um tempo-espaço interior, psicológico, motivado pelo fluxo da memória dos personagens principais e pelas analepses temporais.

\subsubsection{Espaço}

No romance-seriado Casa de Pensão, a seqüência 03, $1^{\text {a }}$ coluna, revela o Rio de Janeiro desejado pelo protagonista, em que seria: "a primeira vista uma Babilônia, onde ninguém se conhecia, onde cada um podia correr à vontade as suas aventuras, sem fazer escândalo como na província". O livro, por outro lado, apresenta uma visão idealizada da Corte, como "um Paris de Alexandre Dumas ou de Paulo de Kock, um Paris cheio de canções de amor, um Paris de estudantes e costureiras, no qual podia ele à vontade correr as suas aventuras, sem fazer escândalo como no diabo da província". Nos dois textos, a cidade é vista como um lugar de se viver livremente, com liberdade e sem receio de censura (CP, 1977, p.18).

Com o passar dos anos e na medida em que sentia grande desejo de aventurar-se livremente sem a censura de quem quer que fosse, o maranhense decidiu partir para o Rio de Janeiro para entregar-se, completamente, à vida libertina que não poderia ter na província do Maranhão. A seqüência 03 ( $2^{a}$ coluna) relata que "Amâncio sentia necessidade de aventurar algumas das cenas românticas, com que Ihe havia enchido a cabeça. Todo ele reclamava amores, segredos de alcova, loucuras de paixão". No livro, a menção ao Romantismo é retirada e cede espaço ao projeto de Amâncio de "dar começo àquela existência que encontrara nas páginas de mil romances. Todo ele reclamava amores perigosos, segredos de alcova e loucuras de paixão". Essa hipérbole utilizada pelo personagem será explicada na seqüência 05, quando Amâncio está no paquete rumo ao Rio de Janeiro e algumas recordações lançam-no à época em que fugia à noite para entregar-se à boemia maranhense, inspirado nas aventuras lidas em romances românticos.

Apesar de Amâncio chegar em casa ao amanhecer, a agitação era tanta que não o deixava dormir. Enquanto o romance-seriado registra que o maranhense ficava "excitado pelas impressões e pelo vinho da noite" (SEQÜÊNCIA 05, 5 Coluna), no livro (CP, 1977, p. 25), vinho é substituído por bebedeira. Na seqüência, 
se, por um lado, a versão em livro descreve que o personagem: "Atirava-se à rede, com uma vertigem impotente de conceber poesias byronianas, escrever coisas no gênero de Álvares de Azevedo, cantar orgias, extravagâncias, delírios”, por outro lado, o romance-seriado não cita Byron, dando a entender que Amâncio pretendia escrever poesias românticas do "gênero de Álvares de Azevedo", limitando a informação ao poeta brasileiro, o que se remete ao conhecimento prévio que os leitores dos dois grupos poderiam ter da literatura romântica, inglesa e brasileira. Nas duas variantes, há menção a romances franceses: "e afinal adormecia, lendo Mademoiselle de Maupuin, Olympia de Clèves ou Confession d'un enfant du siècle” e, mesmo não conseguindo entender bem este último livro, o conhecimento que tinha da biografia de Musset "embriagava-se com essa leitura; ficava a sonhar fantasias estranhas, amores céticos, viagens misteriosas, amores arriscados e romanescos". No livro ${ }^{65}$, a expressão "amores impossíveis" é alterada por "paixões indefinidas"; o qualitativo de amor "romanesco" é suprimido, o que deixa mais evidente no romance-seriado que o imaginário criado a partir de romances românticos pode ser relacionado ao desejo que Amâncio nutriria por Hortênsia, esposa de Campos.

Amâncio se via no direito de ter experiências sexuais na juventude, pois, nessa época, entendia-se que isso se devia ao instinto sexual masculino:

\footnotetext{
Desde que guarde comedimento pessoal e respeito aos costumes, às leis e ao direito dos outros, um homem solteiro pode muito bem obter seu prazer como o quiser; e seria bem difícil, mesmo nessa moral austera, impor-lhe abstenção absoluta desse prazer enquanto não contrair um casamento (FOUCAULT, 1997, p. 36).
}

Ainda, na quinta coluna da seqüência 05, do romance-seriado Casa de Pensão, podemos perceber que a leitura motivava Amâncio a querer mais do que simplesmente "as criadas da casa ou as da fazenda da avó, ou as mulatas da vizinhança", porque elas "já o enjoavam; era preciso arranjar amores mais finos, mais dignos, que lhe contentassem igualmente as exigências da imaginação". No livro ${ }^{66}$, há um aprimoramento na escrita e referência à satisfação de desejos carnais: "As criadas da casa da avó ou as mulatinhas da vizinhança já o enfaravam: era preciso descobrir amores mais finos, mais dignos, que, nem só lhe contentassem a

\footnotetext{
${ }^{65}$ CP, 1977, p. 25.

${ }^{66}$ Ibidem.
} 
carne, como igualmente the socorressem as ânsias da imaginação". O imaginário criado pela leitura de romances românticos motivou o desenvolvimento de uma das passagens mais românticas de Casa de Pensão. Por esse tempo:

\begin{abstract}
leu a Graziella e o Raphael de Lamartine. Ficou possuído de uma grande tristeza; as lágrimas saltaram-lhe sobre as páginas do livro. Sentiu necessidade de amar por aquele processo, mergulhar na poesia, esquecerse de tudo o que o cercava, para viver mentalmente ${ }^{67}$ nas praias de Nápoles, ou nas ilhas adoráveis da Sicília, cujos nomes sonoros e musicais Ihe chegavam ao coração como o efeito de uma saudade, amarga e doce ${ }^{68}$, de uma nostalgia inefável, profunda, sem contornos, que o atraía para outro mundo desconhecido, para uma existência, que the acenava de longe, a puxá-lo com todos os tentáculos de seu mistério e da sua irresistível melancolia.

Uma ocasião lia a Graziella, deitado ao pé da janela de seu quarto. A tarde precipitava-se no crepúsculo, e enchia a natureza de tons melancólicos e doloridos. Um italiano tocava na rua o seu realejo (SEQÜÊNCIA 05, col. 06).
\end{abstract}

Na versão em livro ${ }^{69}$, o último parágrafo na citação acima é condensado: "Uma ocasião, deitado ao pé da janela de seu quarto, pensava em Graziella".

A seqüência 24 ( $3^{a}$ coluna) descreve quando Amâncio instalou-se na casa de pensão e "nesse momento Amâncio acabava de abrir as janelas do seu quarto, arrastava as malas para o centro e ia tratando de abri-las. As duas apareceram [Amélia e Mme. Brizard]". Acreditamos que o quarto do pensionista era grande, afinal de contas tinha mais de uma janela. No livro $^{70}$, não há menção às janelas e a invasão no quarto é relatada deste modo sucinto: Nesse momento, o rapaz acabava de abrir as malas. As duas apareceram no quarto [...]".

Através das janelas da casa de pensão Amâncio e os colegas de hospedagem observavam o que acontecia nas ruas e casas da vizinhança. $O$ segmento 33 ( $5^{\mathrm{a}}$ coluna) descreve um diálogo entre os jovens:

\footnotetext{
Então, perguntou aquele, o que temos?

- Uma conferenciasinha. Ouve cá.

- $\quad$ E, depois de meterem-se ambos no vão de uma janela, Amâncio principiou com acentuações de quem detesta imoralidades: [...].
}

\footnotetext{
${ }^{67}$ A palavra "mentalmente" foi inserida na versão em livro.

${ }^{68} \mathrm{O}$ aspecto antitético da saudade está presente nas duas versões do romance.

${ }^{69} \mathrm{CP}, 1977$, p. 25.

70 Ibidem, p. 76.
} 
No livro ${ }^{71}$, por outro lado, há uma condensação das informações que descrevem esse episódio; o discurso direto é substituído pelo indireto: "Os dois rapazes meteram-se ambos no vão de uma janela da sala de visitas. E Amâncio com acentuações de quem detesta imoralidades, disse ao outro, sem transição: $[\ldots] "$.

Como morar na casa de pensão confundia as esferas do público e do privado, a seqüência 23 ( $5^{\mathrm{a}}$ coluna) descreve uma situação em que o jantar se prolongou e o advogado Tavares começou a discursar, então, como era de costume: "Enquanto ele orava, vários hóspedes recolhiam-se para os seus quartos, atravessando na ponta dos pés o corredor do fundo da varanda, para não serem obrigados a ouvi-lo". O livro ${ }^{72}$ especifica que os hóspedes iam para os seus "competentes quartos, atravessando a varanda pelo fundo na ponta dos pés, com medo da “caceteação'”.

A festa oferecida na casa do Melo é um modo de Amâncio aproximar-se de Hortênsia. Como o romance-seriado apresenta fragmentos da história, as descrições são mais ricas de detalhes; o cenário e as sensações assumem linguagem plástica. "Os Pares cruzavam-se no meio da sala do Melo, formando as marcas da contradança, aos gemidos histéricos das rabecas; Um cheiro híbrido de extratos odoríferos das flores que se fanavam em grandes vasos japoneses e de sutil pituita dos corpos fatigados das mulheres, espalhavam-se no ambiente cor de pérola e penetrava a carne com a subtilidade de um veneno lento e delicioso como o fumo de um tabaco" (SEQÜÊNCIA 26, $3^{\mathrm{a}}$ coluna).

No livro, a amada de Amâncio aparece na posição de observadora: "Hortênsia olhava para isso, enquanto, ao gemer das rabecas, cruzavam-se na sala os pares, marcando contradanças. $O$ aroma das flores que se fanavam em grandes vasos japoneses, misturava-se ao cheiro das mulheres, e penetrava a carne com a sutilidade de um veneno lento e delicioso como o fumo do charuto" ${ }^{\text {"73. }}$.

É interessante o modo como ocorre o comentário sobre o passeio realizado pelos donos da casa de pensão. No romance-seriado, o narrador exerce função de intermediário do diálogo, que resulta na mistura do discurso direto e indireto e a presença de três vozes:

\footnotetext{
${ }^{71}$ Ibidem, p. 97.

72 Ibidem, p. 71.

${ }^{73}$ Ibidem, p. 80.
} 
O Campos está de passeio com a família lá para...

Não se lembrava o nome do jardim.

- Ora senhores um jardim tão falado!

- Botânico?! Ajudou o outro.

- Isso - Jardim Botânico! Eu ainda não fui lá, mas dizem que é muito lindo!

- Esplendido!" (SEQÜÊNCIA 17, 2ª coluna).

O livro apresenta a narração desse episódio de maneira direta, com supressão de marcas da oralidade: "O Campos está de passeio com a família para o tal Jardim Botânico"74.

A seqüência $22,3^{\text {a }}$ coluna e o conteúdo registrado na versão em livro dialogam com a Questão Capistrano ao mencionar que: "Vibrou então o piano na sala. Mme. Brizard lembrou que seria melhor mudarem-se para lá. Amâncio que não parara de conversar com Lúcia, ofereceu-Ihe o braço e seguiram juntos". No livro $^{75}$, essa passagem sofre algumas alterações: "Vibrou então o piano no salão de visitas.

- É melhor irmos todos para lá, alvitrou a dona da casa.

O marido e o Lambertosa aceitaram logo a idéia, e Amâncio, sem interromper a conversa com a mulher do Pereira, a esta deu o braço e seguiu o exemplo daqueles".

A dialogia entre ficção e história ocorre pela coincidência de existir piano na casa de pensão ocupada por Amâncio, assim como onde Capistrano da Cunha era hóspede. Destacamos que dona Júlia Clara Pereira, mãe do assassino de Capistrano, era modesta professora de piano. Na ficção, Amélia e Lúcia tocam piano.

\subsubsection{Tempo}

A analepse empregada ao longo do Capítulo 1 da versão em livro se aproxima muito da técnica do romance-seriado de "conduzir para trás" e condensação de acontecimentos não finalizados, que o autor utiliza para mergulhar seu leitor na ação das seqüências curtas do romance-seriado, como a carta escrita à mãe, os amores vividos pelo protagonista, a retirada do enxoval da arca, apesar de essas passagens sofrerem muitas modificações na variante em livro.

\footnotetext{
74 Ibidem, p. 57.

75 Ibidem, p. 69.
} 
As anacronias, denominadas por Gérard Genette (1995) como analepses, estão presentes no discurso de Casa de Pensão como recuos no tempo. O início da narrativa apresenta a chegada de Amâncio ao Rio de Janeiro e seu primeiro contato com Campos. Posteriormente, ocorrem recuos temporais, tais como à infância do protagonista e aos momentos que antecederam sua partida do Maranhão. A figura da mãe é uma espécie de atalho ou link para as melhores lembranças tidas em sua vida, por isso, cada reminiscência da mãe traz consigo analepses que se remetem a ela.

Silva (1983, p. 293-306) destaca que:

\begin{abstract}
a analepse é um recurso de que os romancistas se servem com freqüência, porque permite comodamente esclarecer o narratório sobre os antecedentes de uma determinada situação [...]. A narrativa analéptica desempenha uma função muito relevante no romance naturalista, em estreita interdependência com a concepção positivista do mundo que rege este romance. Após a apresentação das personagens principais, o romancista naturalista recorre logicamente a analepses mais ou menos extensas para analisar, segundo a ótica positivista, as forças determinantes - hereditariedade, influência do meio, constituição fisiológica e temperamental - que modelam aquelas personagens.
\end{abstract}

A dor, revolta e falta de vocação para o estudo também marcam os primeiros anos escolares de Amâncio e estabelecem conexão com a necessidade de ser confortado pela mãe. A cronologia marcada nos primeiros capítulos de Casa de Pensão, tanto na versão em livro quanto no romance-seriado, é definida pelo fluxo da consciência impulsionado pelas lembranças desse tempo, que ainda não podiam ser apagadas devido às marcas profundas que os castigos imprimiram em Amâncio.

Antes de serem apresentadas informações sobre sua ama-de-leite e seus primeiros dias de vida, são reveladas as experiências que o protagonista teve no ambiente escolar:

\footnotetext{
- Aos sete anos entrou para a escola. Que horror!

O mestre, um tal José Antonio Pires, homem grosseiro, bruto, de cabelo negro e olhos de touro, batia nas crianças por gosto, por um habito do ofício.

$\mathrm{Na}$ aula falava a berrar, como se dirigisse uma boiada. Tinha as mãos grossas, a voz dura, a catadura selvagem. Quando bebia demais ao jantar, ficava pior. (SEQÜÊNCIA 03 - Col. 03).
}

Aos dez anos, depois que Amâncio havia sofrido muitos castigos, convenceuse de que era melhor omitir seu ponto de vista a respeito das injustiças que 
observasse. A dissimulação do personagem pode ser observada neste excerto: - É uma menina! dizia a mãe, convicta - Amancinho tem dez anos e é um anjo de candura! (SEQÜÊNCIA 04, coluna 03).

A próxima marca temporal é realizada no relato de que "Só aos doze anos fez o seu exame de português na aula do Pires". Se fosse aprovado, poderia ingressar no Lyceu: “E só de pensar n'isso, só de se lembrar que já não estava ao alcance das garras do Pires, o coração saltava-Ihe de alegria" (SEQÜÊNCIA 04, Coluna 06).

Aos vinte anos, Amâncio parte para o Rio de Janeiro, afinal de contas: "Há muito tempo já devia ter ele partido-o filho de fulano fora aos quinze anos, o de beltrano voltara com vinte e três, e Amâncio já tinha vinte. la tarde!" (SEQÜÊNCIA 06, Coluna 02).

A partir das informações extraídas do romance-seriado, que estabelecem semelhanças com o sentido impresso no livro, podemos constatar que a duração dos acontecimentos na sucessão diegética, em relação à temporalidade do segmento diegético da chegada de Amâncio à Corte, configura-se em uma temporalidade segunda, dando assim lugar à analepse.

No espaço do Rio de Janeiro, a marca temporal da diegese de Casa de Pensão está delimitada e caracterizada pela indicação do calendário escolar -, pois Amâncio chegou ao Rio quando o período de matrícula já havia passado, por isso Campos precisou ajudá-lo a conseguir matricular-se fora do prazo. Como parte da cronologia ligada ao calendário escolar foi registrada apenas no livro, na medida em que a hipertrofia da intriga foi desenvolvida, essa foi a fonte de onde foram extraídas estas informações complementares:

Queria ver se era possível matricular-se esse ano na Escola de Medicina. Não negava que se havia demorado um pouquito nos preparatórios...mas seria dele a culpa?... Só com umas sezões [febres] que apanhara na fazenda da avó, perdera três anos (CP, 1977, p. 14).

Afinal, graças aos esforços de Campos, conseguiu matricular-se na academia, duas semanas depois de ter chegado ao Rio de Janeiro (CP, 1977, p. 28).

Soubera do resultado no mesmo dia da prova oral, por intermédio de um dos professores. - Saíra aprovado plenamente. Vencera! [...].

Todavia, Amâncio, em ar feliz e pretensioso, confessava o pouco que estudara e gabava-se de sua fortuna. - Podia dar a palavra de honra em como mal havia tocado nos livros durante o ano. - O Coqueiro e a família estavam ali, que dissessem!... (CP, 1977, p. 148). 
Além disso, as cartas de Ângela repetiam-se agora desesperadamente. "Estaria a pobre mãe com efeito em risco de vida?...". pensava Amâncio.

Dependeria dele o salvá-la? ... E os seus interesses que havia tanto tempo o reclamavam?... E as saudades da pátria? E os prazeres que encontraria à volta do primeiro ano acadêmico? (CP, 1977, p. 166).

Na comparação das duas versões de Casa de Pensão, podemos constatar que Amâncio tinha plena consciência da falta de vocação para os estudo. $\mathrm{Na}$ seqüência $35,5^{\text {a }}$ coluna, o protagonista desabafa: “- Oh! Os estudos! Os estudos eram a aza negra de sua vida, o espectro terrível de seus sonhos! por melhores que fossem as regalias que daí pudessem vir, nunca seriam capazes de compensar aquela profunda tristeza, o aborrecimento invencível, que o devoravam naquele momento". No livro ${ }^{76}$, lemos: "- Oh! Os estudos! Os estudos eram o ponto negro de sua vida, o seu desgosto, o terrível espectro de todos os seus sonhos! As regalias que daí viessem mais tarde, fossem elas quais fossem, nunca poderiam compensar aquela profunda tristeza, aquele aborrecimento invencível, que o devoravam".

No entanto, a citação abaixo apresenta um paradoxo se comparada às anteriores, ou seja, mesmo sem vocação para os estudos ou esforço, Amâncio obtém êxito. A aprovação obtida no primeiro ano do curso de Medicina projeta em Amâncio imagens da glória que teria ao ser aplaudido pelos conterrâneos:

\footnotetext{
Os prazeres, sim, que Amâncio, pelo derradeiro paquete, recebera em uma das principais folhas diárias de sua província a seguinte notícia:

"MARANHENSE DISTINTO. Acaba de fazer brilhantemente o primeiro ano de seu curso na Escola de Medicina na Corte o nosso talentoso comprovinciano Amâncio da Silva Bastos e Vasconcelos, filho de há pouco falecido e sempre chorado Comendador Manoel Pedro de Vasconcelos, um dos mais estimados negociantes que foi desta praça, enquanto não podemos pessoalmente abraçar o digno jovem e esperançoso discípulo de Hipócrates, apressamo-nos a enviar-Ihe daqui os nossos sinceros parabéns, faturando em S. S.a mais uma glória legítima para a nossa Atenas, já tão rica, aliás, em talentos privilegiados!” (CP, 1977, p. 166).
}

Em meio a analepses longas, a narração de acontecimentos segue um ritmo lento. O cronótopo central é Maranhão/infância-adolescência e Rio de Janeiro/juventude desregrada. O discurso diacrônico das notícias que sintetizam a Questão Capistrano assume caráter sincrônico no livro.

${ }^{76}$ CP, 1977, p. 101 


\title{
3.6 Personagens
}

A diegese de Casa de Pensão é caracterizada pela referência a um acontecimento, assistido por muitos leitores do romance-seriado, e pela construção de uma história que carrega marcas dessa época, cujos valores são apresentados pelos personagens e o narrador, como fruto do posicionamento ideológico do autor. Nessa perspectiva:

\begin{abstract}
Uma história descreve uma seqüência de ações e de experiências feitas por um certo número de personagens, quer reais, quer imaginários. Esses personagens são representados em situações que mudam ou a cuja mudança reagem. Por sua vez, essas mudanças revelam aspectos da situação e das personagens e engendram uma nova prova (predicament), que apela para o pensamento, para a ação ou para ambos. A resposta a essa prova conduz a história à sua conclusão (RICOEUR, 1995, 214).
\end{abstract}

Nos estudos realizados em Prosa de Ficção, Lúcia Miguel Pereira (1950, p. 126 apud SÜSSEKIND, 1984, p. 121) observa que, nas últimas décadas do século XIX, portanto, na época em que Casa de Pensão surgia, coincidia com um momento em que "se processavam experiências raciais da maior importância, onde as condições de existência variavam dos requintes sofisticados da Corte ao primitivismo das populações rurais, onde as relações de senhores e escravos suscitavam um sem número de problemas", em meio a essas transformações, "os romancistas que se criam realistas voltavam-se de preferência para os casos de alcova, para a análise de temperamentos doentios".

Ao focalizar um recorte de mundo ligado a acontecimentos relacionados com o desenvolvimento sociocultural brasileiro, Aluísio Azevedo atribui historicidade ao texto literário, ao mesmo tempo em que registra vozes de uma época em que o escritor testemunhara. A segmentação dos capítulos em um conjunto de seqüências da obra resulta na fragmentação do discurso. Com a descontinuidade, o discurso de Casa de Pensão apresenta indícios organizacionais que se remetem a questões que vão além do universo estrutural do texto, tendo em vista que essa estratégia narrativa articula-se a perspectivas ligadas a imagens preservadas na memória de muitos leitores ou expectadores da Questão Capistrano, que transparecem em meio à odisséia da vida de Amâncio de Vasconcelos.

Assim como a publicação, a descrição da personalidade do protagonista também é apresentada de modo segmentado, a partir de analepses, suscitadas em 
momentos em que Amâncio sente saudades de Ângela, sua mãe e protetora, o que denota a configuração de um sujeito vulnerável a crises de ordem emocional e perturbado quando se via sozinho. A partir da terceira seqüência do romanceseriado, a identidade do personagem é apresentada de modo que a unidade identitária seja dificultada entre o ser e o parecer - criança doente, aluno indisciplinado, filho fingido, neto rebelde, aventureiro, pervertido, conquistador, oportunista, inconseqüente - constroem o perfil do personagem.

O jogo de antíteses na definição do caráter multifacetado de Amâncio transparece no universo interno e externo do romance, na medida em que o personagem é descrito, em meio às peripécias que o envolvem. Na primeira seqüência há a apresentação de Amâncio a partir de seus aspectos físicos. Nas seqüências três e quatro é revelado é apresentado o perfil psicológico do personagem.

Como o fio condutor da narrativa está profundamente ligado às ações que envolvem os interesses de Amâncio e a sua dificuldade de vencer os obstáculos que Ihe atormentam, os demais personagens se aproveitam da fraqueza do maranhense e tentam tirar proveito da falta de perspicácia dele. Na medida em que a hipertrofia da intriga se desenvolve, Amâncio parece reproduzir a voz de Capistrano, ao mesmo tempo em que mostra grande semelhança entre o espaço e os espectadores das duas tragédias. Portanto, a relação dialógica entre ficção e a Questão Capistrano passa por reformulação no movimento criativo de Casa de Pensão e aproxima os personagens de seus modelos.

Brayner (1973, p. 44) destaca que: "Diferente de O Cortiço, Casa de Pensão ainda possui um personagem principal em torno do qual se engloba a intriga"; no entanto, é evidente a "predileção por seqüências em que um maior número de participantes age e se entrecruza em diálogos na caracterização de tipos e ambientes".

\subsubsection{A construção da psicologia do protagonista}

Publicado em 1888, O Ateneu tem como base experiências vividas pelo próprio autor, no Colégio interno Abílio. Em 1873, Raul Pompéia inicia uma fase nova, deixando para trás o ambiente familiar. $\mathrm{Na}$ análise de $\mathrm{O}$ Ateneu, Brayner (1979, p. 144-145) destaca que: 
O recurso do romance autobiográfico em que um narrador em profundo de frustração resolve contar uma situação de crise existencial vai ter, a partir do final do século XIX, no Brasil, uma crescente importância. A fratura de uma vida interior torna-se a perspectiva de análise de um sujeito atemorizado, satírico ou melancólico [...].

Memória de adolescente ou de adulto, estará cristalizada em torno de um desejo impossível, de uma questão insolúvel. Em volta haverá como realidade, apenas as fantasmagorias do presente e a dor da solidão: consciência e ação estão radicalmente separadas.

Se em O Ateneu há a imagem caricata do diretor Aristarco, em Casa de Pensão são pintados os defeitos de José Antonio Pires, professor que Aluísio teve nos primeiros anos de estudo. Em meio à projeção do escritor, narradorpersonagem, há uma mescla entre experiência e o discurso ficcional das duas variantes. Embora a seqüência 03 ( $3^{\text {a }}$ coluna) apresente o nome completo do seu professor "um tal José Antônio Pires" e a variante em livro exclua o primeiro nome do mestre, limitando-se a denominá-lo como "um tal Antônio Pires", ambas as versões descrevem-no como "homem grosseiro, bruto, de cabelo negro e olhos de touro, batia nas crianças por gosto, por um hábito do ofício".

Ao retratar o método de ensino pelo viés do autoritarismo, Aluísio revela que os dois professores se valiam da crueldade física para manter a disciplina em sala. Menezes (1958, p. 56), estudioso da biografia de Aluísio Azevedo, ressalta que Dona Ângela superprotegia Amâncio o filho, da mesma forma que Dona Emília, mãe de Aluísio, pois:

não concordava, em absoluto, com tal tratamento dispensado ao filho querido [Aluísio]: 'fosse-o apanhar palmatórias de um brutalhão daquela ordem! Ora isso não tinha jeito!' Mas, o Vice-Cônsul [pai de Aluísio], com outra mentalidade, costumava retrucar: 'Que deixasse lá o pequeno com o mestre!...Mais tarde ele havia de agradecer aquelas palmatoadas'. O certo é que o aluno Aluísio 'fora sempre tido e havido pelo pior dos meninos da aula, pelo mais atrevido e insubordinado.

Segundo Bakhtin em Questões de Literatura e de Estética (1998, p. 417), o romancista pode trabalhar em relações dialógicas híbridas, tanto no discurso do narrador/testemunha quanto no dos personagens, pois:

[...] aparecer no campo da representação em qualquer atitude, pode representar os momentos reais da sua vida ou fazer uma alusão, pode se intrometer na conversa dos personagens, pode polemizar abertamente com os seus inimigos literários, etc. Não se trata somente da aparição da imagem do autor no campo da representação, trata-se também do fato que 
o autor autêntico, formal e primeiro (o autor da imagem do autor) redunda em novas relações com o mundo representado: elas se encontram agora naquelas mesmas medidas exiológicas e temporais, que representam num único plano o discurso do autor com o discurso do personagem representado e que pode atuar junto com ele (mais exatamente: não pode deixar de atuar) nas mútuas relações dialógicas e nas combinações híbridas.

Se o autor-criador estabelece uma relação oxióloga com o herói, evidenciada pelas vozes dos homônimos professores Pires, dos seus alunos Aluísio e Amâncio, ou ainda de Amâncio e Capistrano, alguns receptores imanentes conseguirão perceber uma correspondência dialógica com os modelos projetados pela ficção. A focalização (ou ponto de vista) permite ao autor uma construção mais livre, privilegiada por ter sido testemunho e participante de algumas das situações narradas. No entanto, "o mundo representado, mesmo que seja realista e verídico, nunca pode ser cronotopicamente identificado como o mundo real representante, onde se encontra o autor-criador dessa imagem" (BAKHTIN, 1998, p. 360).

Com a apresentação do excerto acima e a partir de estudo iniciado por Meneses (1958), constatamos que o protagonista é, em certa medida, uma espécie de alter ego do autor, pois, além de ser maranhense, existem outras informações e experiências biográficas análogas, sobretudo quando se trata do ódio nutrido por Pires e da proteção e do amor recebidos da mãe, Dona Emília, que pode ter sido o modelo para a criação da personagem Dona Ângela, mãe de Amâncio. Apesar de ser evidente o recorte de mundo feito por Aluísio, o discurso ficcional passa por alterações no momento em que os onze capítulos do romance-seriado são revidados para a publicação do livro, o que também pode resultar na alteração de ponto de vista. Nos dois casos as mudanças são destacadas em negrito.

Enquanto a seqüência 01 ( $2^{a}$ coluna) destaca que o personagem é conterrâneo do autor, descrito como um tipo do "Norte do Brasil", de "estatura mediana, pescoço fino, cabelos crespos e olhos muito vivos e inteligentes, se bem que constrangidos por um leve estrabismo", a variante em livro ${ }^{77}$ registra apenas que se trata de um "tipo do Norte, franzino, amorenado, pescoço estreito, cabelos crespos e olhos vivos e penetrantes, [mas não inteligentes] se bem que alterados por um leve estrabismo".

Quando o autor tipifica o protagonista, o faz a partir de um retrato dos efeitos das pressões naturais e sociais, já que a visão determinista aponta o comportamento

${ }^{77}$ CP, 1977 , p. 13. 
dos personagens como decorrente de forças que escapam a seu controle. Essas marcas aparecem como resultado da observação, com características muito fortes e concretas.

Depois de descrever as características físicas, que atribuem delicadeza a Amâncio, o narrador revela o que há por trás da máscara do protagonista porque: "Ninguém, vendo aquele pequeno rosto moreno, um pouco chupado, com as maçãs salientes, os olhos pretos, de uma vivacidade infantil, a boca estreita, guarnecida de bons dentes, claros e bem alinhados" poderia imaginar, "que ali estava um sonhador e um sensual daquela força" (SEQÜÊNCIA 03, $2^{a}$ coluna). No livro $^{78}$, a alteração de alguns sinônimos não modifica a caracterização gradual da fisionomia do personagem, diferenciando-se apenas na descrição deformadora escondida por trás das características singelas, na medida em que o conteúdo do livro acentua que "[...] ninguém acreditaria que ali estivesse um sonhador, um sensual, um louco".

Como nada foge ao olhar do narrador, que acompanha o movimento dos personagens, da mesma forma que o autor acompanha os bonecos de cartolina sobre a mesa de trabalho (MENEZES, 1958), a seqüência 27 ( $3^{a}$ Coluna) revela a voz do narrador, que desvenda o protagonista, um rapaz de vinte anos: "Em questão de saias principalmente ninguém lhe levava a melhor. As mulheres eram o seu fraco, eram o seu vício; várias anedotas suas a esse respeito corriam de boca em boca [...]". O livro ${ }^{79}$, por sua vez, não apresenta alguns dos elementos que intensificavam o vício de Amâncio, limitando-se a revelar que: "As mulheres eram o seu fraco, o seu vício mais acentuado; várias anedotas suas, inspiradas neste assunto, corriam de boca [...]".

Além das mulheres, a bebida era outro vício na vida de Amâncio. Em uma dada ocasião, quando já não suportava mais ficar debaixo das asas de Campos, estava andando pelas ruas do Rio de Janeiro e deparou-se com Paiva, com quem havia estudado quando era aluno do professor Pires. Nesse mesmo dia, Amâncio sugeriu pagar-Ihe um almoço para comemorarem o reencontro. Ao se aproximarem do estabelecimento, Paiva encontra, casualmente, dois colegas da Politécnica, um deles era Coqueiro, e todos acompanharam Amâncio no almoço, que, por sua vez, deixa claro que irá pagar a conta. A falta de limite para a bebida faz com que Paiva

\footnotetext{
${ }^{78}$ Ibidem, p. 18-19.

79 Ibidem, p. 82.
} 
provoque um escândalo, enquanto Amâncio passa muito mal. A seqüência 09 (5 $5^{a}$ coluna) relata que: "Paiva pretendia provar o contrário, gritando e batendo punhaladas sobre a mesa. Havia já dois copos quebrados. No livro ${ }^{80}$, o nome de Paiva é suprimido, como marca do discurso que condensa informações: "O outro protestava, gritando e batendo sobre a mesa. Havia já dois copos quebrados”. Segundo Luccok (1975, p. 85 apud RIBEIRO, 2000, p. 170) "[...] o caráter reservado, que raramente deixa de se mostrar exagerado nas primeiras horas da festa, vai-se esbatendo e, freqüentemente, as pessoas se atiram ao extremo oposto".

Como Amâncio extrapolou os limites da bebida, precisou ser levado para a casa de Paiva, seu conterrâneo. Lá: "Atirou-se sobre a primeira cama que encontrou e começou a gemer [...] completamente pálido; [...] sem poder fechar a boca e os olhos reviravam-Ihe como em uma crise nervosa" (SEQÜÊNCIA 11, $1^{\text {a }}$ coluna). Sobre esse mesmo episódio, o conteúdo em livro ${ }^{81}$ destaca que, durante a embriaguez, Amâncio ficou "gemendo e resbunando ao peso de uma grande aflição. Estava mais branco do que a cal da parede; o suor escorria-lhe por todo o corpo; respirava com dificuldade; a abrir a boca e a retorcer os olhos". Nas duas citações, podemos visualizar Amâncio como marionete de seus vícios.

Lúcia Miguel Pereira (1975 apud SODRÉ, 1992, p. 215), destaca que: “Em Casa de Pensão ainda há um herói, que é, justamente por ser a mais estudada, a pior personagem do romance, a que mais sofre do determinismo exagerado, por demais evidente, que manietou tantas das figuras da ficção naturalista".

Arrastado pelas leis da hereditariedade, pelos vícios que o consumiam e pela educação opressora que recebera, no decorrer da narrativa o comportamento do personagem é moldado pelos papéis que ele assume, por razões alheias à sua vontade, pois é dominado pelos impulsos. A habilidade de utilizar a máscara social torna-se essencial para que Amâncio seja aceito no meio em que vivia. $\mathrm{Na}$ seqüência 04 ( $2^{a}$ coluna), há uma analepse que retoma acontecimentos ocorridos em sua infância e que o levavam a desenvolver o autocontrole: "Amâncio dominavase, fazia-se sério, com medo de apanhar. Por essa forma foi se tornando reservado e fingido. Sabia afetar seriedade, quando tinha vontade de rir [...]". No

\footnotetext{
${ }^{80}$ Ibidem, p. 37.

${ }^{81}$ Ibidem, p. 40.
} 
livro ${ }^{82}$, esse episódio é descrito com algumas diferenças, pois, por medo da bordoada, o personagem "fazia-se grave, e cada vez ia-se tornando mais hipócrita e reservado [...]". Se, no romance-seriado, o adjetivo "fingido" denota que o personagem fazia com que os outros acreditassem que ele era o que sua imagem transparecia, na versão em livro, o termo "hipócrita" vai além do fingimento, pois o personagem ressalta virtudes e sentimentos que não tem.

Em um momento de descuido, Amâncio, que sempre dissimulou seus sentimentos, mostra-se a favor de que as crianças cometessem travessuras. $\mathrm{Na}$ seqüência 17 ( $6^{a}$ coluna), o pensionista está na sala quando: "Cezar soltou uma risada, e Amâncio apressou-se a declarar que detestava as crianças que não fossem travessas. Ele não queria meninos com propósito de velhos, nem velhos com modos de criança”. No conteúdo do livro ${ }^{83}$, toda parte destacada é suprimida e, em seu lugar, consta apenas que: "César abaixou o rosto com uma risada, e Amâncio declarou que a travessura era própria daquela idade!", sem, contudo, estender seus comentários moralistas. No entanto, essa supressão não significa que o ponto de vista empregado na narrativa é totalmente reformulado no livro. Ao realizar sua apreciação crítica sobre o romance Casa de Pensão, Valentim Magalhães aplaude-o, classificando-o "profundamente moral como o Primo Basílio" (MAGALHÃES, 1894, p. 96).

No Rio de Janeiro, a liberdade que possibilitava a Amâncio viver livremente sem a censura do pai, acaba por deixá-lo à vontade, sem o uso da máscara no novo meio, por isso, deixava transparecer suas virtudes e defeitos, o que o tornava um jovem oportunista, fútil e extremamente infantil. Como sua fragilidade e riqueza eram notadas facilmente, o maranhense acaba por tornar-se alvo de interesses. Como fora moldado por forças biológicas e sociais, não desenvolveu seu lado espiritual e reflexivo. Movidas pela lei da causalidade, as atitudes do personagem são gratuitas e fundamentadas numa explicação científica presumível, na qual tanto os homens quanto os animais estão sujeitos à mesma lei. Inserido nesse sistema, Amâncio, caracteriza-se como um jovem sem escrúpulos ou objetivos; ao mesmo tempo em que foge dos estudos, entrega-se às paixões inconseqüentes, à luxúria e à vaidade, que culminam em sua morte.

\footnotetext{
82 Ibidem, p. 21.

${ }^{83}$ Ibidem, p. 59.
} 
A seqüência 19 ( $6^{\text {a }}$ coluna) apresenta o momento em que Amâncio chega à casa de pensão, e Coqueiro o trata da melhor maneira possível, escondendo que, por trás disso, há a intenção de casá-lo com sua irmã Amélia. O colega da Escola Politécnica chega a dizer que "- Aqui ficas muito bem! Serás tratado como um filho; em breve terás toda a intimidade com minha família". O livro ${ }^{84}$, no entanto, omite alguns desses detalhes, preservando apenas a informação de que: “- Ficas aqui muito bem! Serás tratado como um filho". Esse momento, descrito nas duas versões de Casa de Pensão, assume grande proximidade com a Questão Capistrano, na medida em que é possível ver em Coqueiro a imagem de Alexandre Pereira, que, em 1876, convidou o colega da Escola Politécnica para ser pensionista na casa em que morava com a mãe e a irmã.

A entrada de Amâncio à casa de pensão pode ser entendida como o momento em que o personagem cai na armadilha criada por Coqueiro. A análise do comportamento do personagem e das estratégias criadas para sobreviver em seu meio caracteriza uma visão biológica do ser humano em sua inclinação para o duplo, que se alterna de acordo com as situações e os interesses. Desse modo, tanto Amâncio quanto os personagens a ele relacionados na intriga agem de acordo com seus interesses, de forma análoga aos indivíduos envolvidos com Capistrano.

A caracterização dos elementos presentes em Casa de Pensão é, portanto, esquemática e, por "referir-se à aparência física ou aos processos psíquicos de um objeto ou personagem (ou de ambientes ou pessoas históricas etc.), podem salientar movimentos visuais, táteis, auditivos etc" (CANDIDO, 1998, p. 13-14). Como grande parte das ações está voltada para Amâncio, os demais personagens a ele relacionados também são tipificados de acordo com traços concretos, moldados com características de pessoas comuns, com todos os seus contrastes (beleza/feiúra; bondade/maldade; rudeza/requinte, etc.).

Tanto no romance-seriado quanto no livro, a caracterização do protagonista é realizada por meio de linguagem plástica, como se Amâncio fosse uma marionete, que ora é lançada para dentro das aventuras de romances românticos e ora veste a máscara criada para o convívio social. Essa plasticidade remete-nos ao fato de que Aluísio desenhou os personagens de Casa de Pensão em cartolina, cortou-os e depois que todos estavam dispostos sobre sua escrivaninha, deu vida e voz a eles e

\footnotetext{
${ }^{84}$ Ibidem, p. 64.
} 
ao narrador (MENEZES, 1958, p. 150-151). Mario Vargas Lloza, por sua vez, destaca que:

\footnotetext{
O narrador é sempre um personagem inventado, um personagem, um ser de fiç̧ão, igual aos outros, aqueles sobre os quais ele "conta", mas mais importante que eles, porque da maneira como atua - revelando-se ou ocultando-se, demorando-se ou precipitando-se, sendo explícito ou alusivo, falador ou contido, lascivo ou sério - depende que estes nos persuadam de sua verdade ou nos dissuadam dela e nos pareçam marionetes ou caricaturas (LLOZA, 1997, p. 63 - tradução nossa).
}

Nesse mesmo sentido, as representações criadas por Aluísio Azevedo, na tipificação dos personagens, desvendam formas de organização da sociedade através de um microcosmo, como fragmento da realidade apreendida pelos sentidos do escritor, que as técnicas apropriadas permitem que sejam representadas na voz dos personagens e mediadas pelo narrador.

\subsubsection{A figura feminina}

Hortênsia e Ângela são as únicas mulheres que fogem à visão negativa apresentada sobre a mulher. Embora o romance-seriado não apresente as transformações ocorridas com Hortênsia, o desfecho da intriga a desmistifica e de mulher idealizada passa a ser acessível. As demais personagens podem ser qualificadas como mulher-sujeito (Mme. Brizard); mulher-objeto (Amélia); mulhersujeito-objeto (Lúcia), em trocas sexuais.

Nos primeiros momentos na Corte, Amâncio era atormentado pela profunda nostalgia que a distância da mãe Ihe causava. A única forma de aproximar o que estava distante no tempo e no espaço era a lembrança de todo o carinho recebido de Ângela, o seu anjo, e, assim, via-se mergulhado no sonho de revê-la. Se por um lado Ângela e Hortênsia assumiam o papel de mulheres-anjo, Lúcia e Amélia eram vistas como mulheres-diabo, pela forma como levavam Amâncio a aventuras libidinosas.

Embora não tenhamos provas de que Aluísio lia teorias psicanalíticas, o amor incondicional que Amâncio nutria pela mãe e o ódio sentido pelo pai é uma evidência de que o protagonista tinha o "complexo de Édipo" e o medo da castração, 
provocado pelas constantes censuras do pai. Exemplo disso pode ser retirado da seqüência 12 ( $4^{a}$ coluna - que se assemelha ao conteúdo do livro ${ }^{85}$ - quando:

\begin{abstract}
A própria idéia de sua mãe nunca lhe vinha só - havia sempre ao lado dela alguma lembrança enfadonha e constrangedora. Quando estavam juntos, o pai chegava sempre no melhor da intimidade. Ângela retraía-se, cortava em meio às carícias do filho, como se as recebesse de um amante, em plena ilegalidade do adultério. E a lembrança desses beijos furtados, desses carinhos cheios de sobressalto, trouxeram-Ihe logo a idéia as vezes que ele ia se meter no quarto do engomado, de camaradagem com as mulatas da casa, que aí trabalhavam conjuntamente.
\end{abstract}

Sua dependência dos carinhos maternos era alimentada pela superproteção e cumplicidade que o amparava em momentos de sofrimento e dificuldade financeira. Quando estava no Rio, Amâncio recebeu uma carta na qual Ângela dizia: "Se não te chegar a mesada, ou se te vierem a faltar os recursos, escreve-me logo duas linhas, que eu te mandarei o que precisares. Mas não convém que teu pai saiba disso..."86.

Hortênsia foi idealizada como uma substituta da mãe. Embora soubesse dos riscos de se envolver com a mulher de Campos, é difícil imaginar que Amâncio conseguiria ser mais forte que o desejo que o inclinava a ela. A seqüência 13 ( $2^{a}$ coluna) mostra que: Amâncio via-se "aguilhoado pelos sentidos, perdia-se em cálculos, em suposições; tentando penetrar todos os segredos do amor de Hortênsia, fantasiando-se ao lado dela surpreendendo-Ihe os pensamentos, sorvendo-Ihe os olhares". O livro ${ }^{87}$, por sua vez, descreve que o protagonista tenta, em vão, entender os pensamentos da amada, por isso "perdia-se em cálculos infames, em degradantes suposições; tentando, embalde, adivinhar-lhe os pensamentos, penetrar-Ihe nos escaninhos do coração e devassar-Ihe todos os segredos do corpo".

A seqüência 24 ( $4^{a}$ e $5^{a}$ colunas) registra o momento em que Amélia e Mme. Brizard procuram se aproximar de Amâncio com a desculpa de ajudá-lo a organizar o que havia trazido em sua arca:

À proporção que se iam tirando as peças de roupa $\left[\ldots^{88}\right]$ do baú uma tepidez doce e confortável, que lembrava o aconchego morno da família.

\footnotetext{
${ }^{85}$ CP, 1977 , p. 43.

${ }^{86}$ Ibidem, p. 27.

87 Ibidem, p. 45.

88 Ilegível.
} 
Cada objeto trazia ao provinciano mil reminiscências e mil saudades de sua mãe. Um perfume ideal de beijos parecia desprender-se, quando se desdobravam os brancos lençóis de linho. Compreendia que muita lágrima e muito soluço ficaram abafados no fundo daquelas arcas.

Uma vaga tristeza apoderou-se dele, ficou distraído, a olhar silenciosamente para as roupas que as duas mulheres empilhavam no chão e sobre a cama. Afigurava-se-Ihe que um pouco da sua infância, um pouco de sua mãe, fugiam para sempre com aqueles perfumes que se evaporavam. E compreendeu, sentiu, que seu coração, à semelhança daquelas arcas, havia também de ir perdendo, pouco a pouco, todas as ilusões, todos os perfumes, com que saíra da casa dos seus pais, e que seus afetos, até o próprio amor que dedicara à sua mãe, desarrumadas a primeira vez, nunca mais possuiriam a mesma forma de inocência, a mesma tepidez embalsamadas dos outros tempos.

A versão em livro ${ }^{89}$ apresenta a supressão de grande parte dos textos destacados em negrito acima e acrescenta algumas alterações, dentre as quais destacamos estas principais: "À proporção que se iam tirando as peças de roupa, uma tepidez embalsamada respirava dentre elas; parecia que um perfume ideal de beijos se exalava ao [...]". "percebia-se que muita lágrima e muito soluço ficaram abafados no fundo daquelas arcas. Vieram ao provinciano novas e mais vivas saudades de Ângela". Além disso, a versão em livro apresenta o diálogo entre a linguagem verbal e a pictórica, com a união de códigos semióticos para atribuir movimento ao discurso de Casa de Pensão.

\footnotetext{
${ }^{89}$ Ibidem, p. 76.
} 


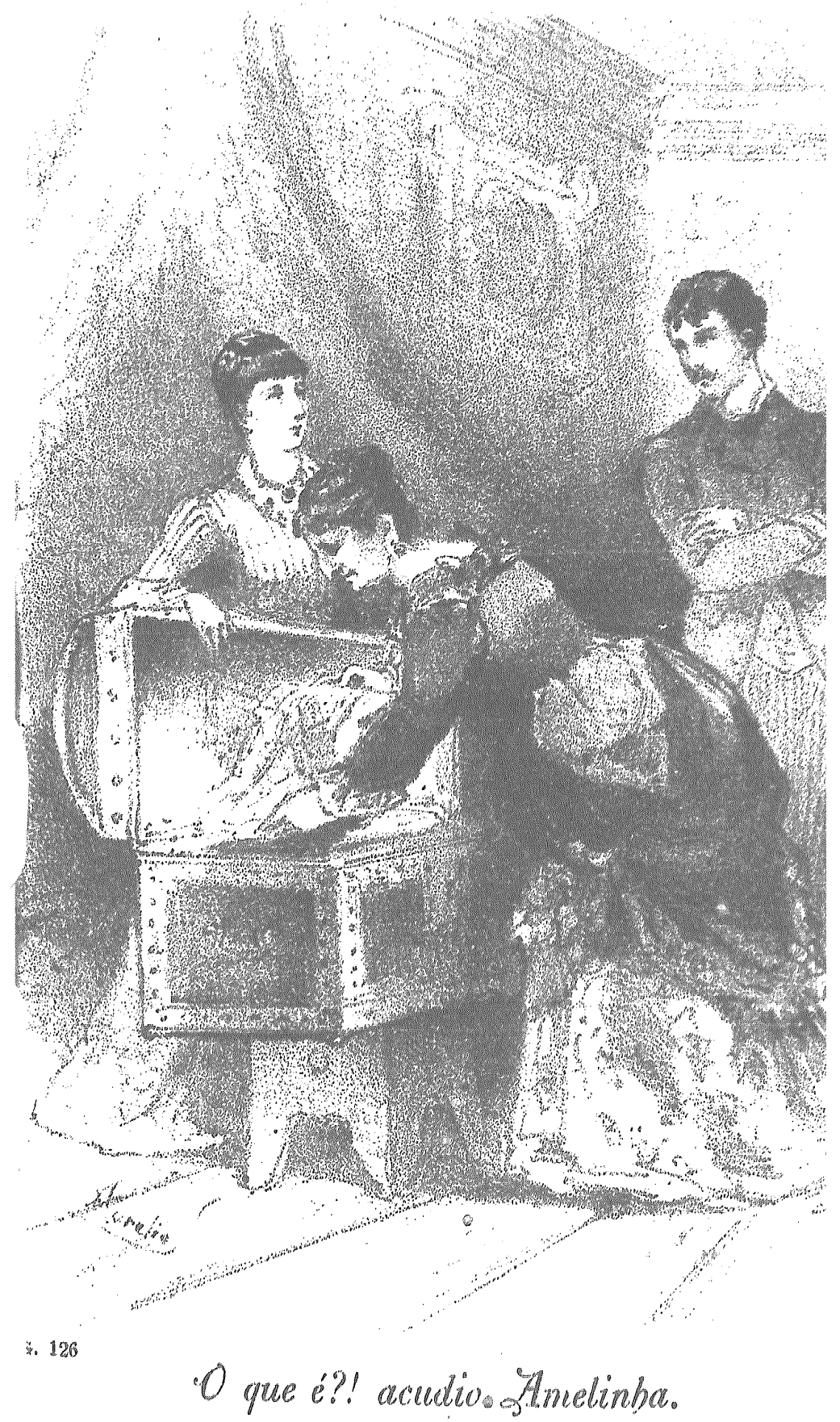

Figura 1: estampa litrografada pelo pintor Aurélio Figueiredo, localizada entre as páginas 48 e 49 primeira edição (popular) de Casa de Pensão, editada por Faro \& Lino - RJ, em 1884. 
Durante essa cena, o narrador de Casa de Pensão apresenta o diálogo entre Amâncio e a dona da casa de pensão, no qual discutem sobre os conceitos de mulher. No romance-seriado Amâncio defende a mulher da província, conforme pode ser observado a seguir.

O pobre marido é quem menos as possuem por que elas nem se lembram que o desgraçado existe!

- Não é tanto assim, Mme. Brizard! Respondia Amâncio - não é tanto assim! Acredito que as mulheres em geral são exigentes, mas não acredito que as da corte sejam menos que as da província; são a mesma coisa, com a diferença que a provinciana é muito mais modesta e simples nas suas aspirações. Por isso mesmo que o Rio de Janeiro é para ela um sonho dourado, um ideal, contenta-se simplesmente com isso; ao passo que a outra, não! Visto que a corte é comum, é o vulgar, ela estende a sua ambição e quer Paris (SEQÜÊNCIA 25, $2^{\mathrm{a}}$. coluna).

As alterações realizadas na versão em livro demonstram a preocupação do autor quanto à representação da figura feminina:

E o pobre marido de semelhante gente, depois de arruinado e depois de passar uma existência sem amor e sem aconchegos de família, ainda terá de suportar as queixas e os ressentimentos de uma mulher desiludida e blasé 90 .

- Perdão! Replicou o estudante. Isso prova simplesmente que toda a mulher, seja da província ou da Corte, apresenta sempre certa dose de ambições. Com a diferença, porém, de que a provinciana, por isso mesmo que o Rio de Janeiro é o seu ideal, é o seu sonho dourado, contenta-se com ele; enquanto que a outra, visto que o supradito Rio de Janeiro para ela nada mais é que o comum, estende naturalmente a sua ambição - e quer Paris [...]. (CP, 1977, p. 77).

O fato de Mme. Brizard possuir pensamento próprio e defender sua opinião quando se via inserida em uma discussão polêmica fazia com que Amâncio a visse como um perigo. A seqüência 17 ( $2^{a}$ coluna) destaca que: "Amâncio principiava a desconfiar que Mme. Brizard não morria de amores pelo silêncio, e que talvez estivesse ali uma dessas caceteadoras de enlouquecer um sujeito". No livro ${ }^{91}$, não consta o constrangimento que sentia pela falação de Brizard: "Amâncio principiava que aquela francesa não era nada menos que uma formidável 'cacete'”.

${ }^{90}$ Blasé é uma expressão francesa que denomina o comportamento indiferente em relação às "novidades" do mundo.

${ }^{91}$ CP, 1977, p. 59. 
Embora tivesse consciência de que os leitores da época estavam habituados à leitura de romances românticos, Aluísio não deixava de apresentar um retrato da realidade a que assistia. Segundo Araripe (1959, p. 375 apud BRAYNER 1973, p. 18): "as mulheres, brasileiras pelo menos, não querem que lhes pinte os defeitos. Ficam muito mal acostumadas com as exibições dos tipos louros e amoráveis de Alencar e os irrequietos e mimosos de Macedo [...]". Por outro, o crítico ressalta "as mulheres são de carne e osso e concentram muita maldade e leviandade".

Mesmo tentando controlar a vontade de intrometer-se na vida do hóspede, Mme. Brizard não conseguia respeitar algumas atitudes tomadas por Amâncio. Ele era constantemente vigiado e não se via livre para fazer agrados com o que a mãe havia Ihe enviado do Maranhão. Na seqüência 38 ( $6^{a}$ coluna), a francesa coloca-se no direito de desaprovar o fato de Amâncio presentear hospedes da casa: “- Oh! fez a Mme. Brizard escandalizada - Isso é que não foi nada bonito! A gente aqui a matar-se, a desfazer-se em carinhos, e ele a socar os presentes que recebe da família no bandulho daquela bicha! Não! Isso não Ihe perdôo!”. Na versão em livro $^{92}$, as alterações realizadas não modificam a insatisfação demonstrada pela dona da casa de pensão.

A seqüência 29 ( $3^{\mathrm{a}}$ e $4^{\mathrm{a}}$ colunas) contém um relato de uma crise de histerismo sofrida por Nini, filha de Mme. Brizard:

- Esta infeliz menina! exclamou, depois de um entroite de vinte minutos. - Esta infeliz menina, senhores! nada mais é do que uma imbele vítima de todos os impulsos, que $\left[. .{ }^{93}\right]$ haver no coração terno e carinhoso da mulher! Vede como o seu semblante é meigo e dolorido, como seus olhos falam a misteriosa linguagem do amor, como a sua boca... Mme. Brizard ergueu-se para pedir ao Dr. Tavares que se deixasse daquilo, por amor de Deus!

No livro, esse episódio ganha maior destaque. A voz do hóspede Dr. Tavares sufoca a voz de Nini. A voz dele representa o posicionamento de um advogado em pleno tribunal, como se Nini fosse sua cliente. Com muita veemência e linguagem ritmada, finaliza seu discurso dizendo que Nini precisa casar-se para poder viver:

Pintou floreadamente o lamentável estado de Nini. Qualificou-a de "vítima inocente dos impenetráveis caprichos de Deus" descreveu a dolorosa expressão do semblante da "infeliz moça", disse que os olhos dela falavam a misteriosa linguagem do amor, e, quando se dispunha a dar afinal a sua esperada opinião sobre o casamento, a pobre enferma,

\footnotetext{
92 Ibidem, p. 109-110.

93 llegível.
} 
muito vendida com o que vociferava o tagarela a seu respeito, abriu a soluçar estrepitosamente. A francesa ergueu-se, de mau humor, para pedir ao Dr. Tavares que se calasse, "por amor de Deus!". Doutro lado o Coqueiro também Ihe suplicava ao advogado que se calasse.

Mas o demônio do homem já se não podia conter. As palavras borbotavam-lhe da língua, como o sangue de uma facada. Fez imagens poéticas sobre o casamento, citou nomes históricos, e jurou, à fé de suas convicções, "que aquela desventurada criatura precisava de um esposo, mais do que as flores carecem do orvalho, mais do que as aves carecem do ar; mais do que os cérebros carecem de luz!" (CP, 1977, p. 86)

A esse respeito, Süssekind (1984, p. 126) destaca que: "Resta às histéricas buscar os laços femininos na reprodução dos comportamentos prescritos médica e moralmente para a mulher: o casamento e a procriação". Como são freqüentes as imagens de histerismo nos romance de Aluísio Azevedo, o exemplo acima retoma o comportamento histérico de Ana Rosa, de O Mulato, que tinha constantes crises de choro. Além disso, grande parte dos romances que retratam os costumes da sociedade brasileira da segunda metade do século XIX descreve que à mulher existiam dois sonhos: o matrimônio e a maternidade.

No romance Casa de Pensão, o comportamento de Amélia denota, em maior grau da versão em livro, que a sexualidade é analógica ao dinheiro. Se, por um lado, o romance-seriado apresenta uma Amélia reflexiva, contrária ao plano ambicioso do irmão e da cunhada, por outro lado, o livro suprime esse fato, o que resulta na alteração da caracterização do caráter da jovem. Na seqüência 16, coloca-se em evidência o ponto de vista de Amélia e a revolta que sentia por ser guiada pelo irmão, o que não é preservado na publicação em livro. Por outro lado, alguns trechos adicionais ressaltam o medo que ela tinha de não se casar, porque "não queria ficar solteirona" e, além disso, o casamento significava uma possibilidade de adquirir uma boa posição social. A primeira Amélia desaparece na versão romântica da personagem. Em uma crônica publicada no jornal $O$ Pensador, em São Luís do Maranhão, Aluísio apresenta uma visão positivista: “Do procedimento da mulher (...) depende o equilíbrio social, depende o equilíbrio político, depende todo o estado patológico e todo o desenvolvimento intelectual da humanidade" (O PENSADOR, 10 dez. 1880 apud MÉRIAN, 1988, p. 166-167).

Quando Walnice Nogueira Galvão (1981, p. 8 apud SÜSSEKIND, 1984, p. 147) destaca que: "Mulher, maior de um lado, acima da determinação anatômica; menor, de outro, suspensa de acesso à maturidade, presa ao laço paterno, mutilada 
nos múltiplos papéis que natureza e sociedade the oferecem", podemos imaginar Amélia atormentada pelo desejo de casar-se e acabar com a intromissão de Coqueiro e Mme. Brizard. Essa Amélia que desenvolve um solilóquio para abafar os conselhos da francesa revelam uma jovem reflexiva e crítica:

Aquela vida de solteira ia com efeito a enfastiando de dia para dia. Já não estava com idade para ser governada como uma criança. Não sabia o que diabo queria dizer uma mulher como ela ser diariamente tratada com pieguices e com as insuportáveis cautelas com que em geral tratam as meninas. - Não estava para isso! Com a educação que Ihe coube e com o meio em que se desenvolveu sabia perfeitamente o que era pão e o que era queijo; por conseguinte as reservas de Mme. Brizard e as discrições do irmão, irritavam-na (SEQÜÊNCIA 16, colunas 01,02 e 03).

Na versão em livro ${ }^{94}$ a conversa é reformulada, os solilóquios suprimidos, o que delineia uma Amélia submissa, que se dispõe a ouvir e aceitar que lhe guiem a própria vida:

Ardia, com efeito por achar marido, por se tornar dona-de-casa. A posição subordinada de menina solteira não se compadecia com a sua idade e com as desenvolturas do seu espírito.

Graças ao meio em que se desenvolveu, sabia perfeitamente o que era pão e o que era queijo; por conseguinte as precauções e as reservas, que o irmão tomava para com ela, faziam-na sorrir.

Foi durante a doença de Amâncio que Amélia, cercando-o de cuidados, começou a conquistá-lo, fazendo com que o maranhense visse nela a possibilidade de sentir-se tão bem como se estivesse com a própria mãe. Na seqüência 39 (6 $6^{a}$ coluna), penúltima publicação do romance-seriado, o personagem:

Amâncio, muito desvigorizado com a moléstia, sentia destecerem-se-lhe interiormente os lúbricos impulsos, que a princípio o atraía para ela [Amélia], e dera lugar a uma simpatia tranqüila e doce, como só experimentara ao lado de sua mãe. la-se aos poucos familiarizando com aquela criatura branca e ainda tão nova, que the enchia o quarto com o frescor balsâmico de sua virgindade e rociava-lhe os sentidos com a mimalhice trêfega de sua ternura.

Na versão em livro ${ }^{95}$, Amélia assume uma imagem fraterna que mexia com os sentimentos de Amâncio. Depois que ele ficou enfermo: "sentia perfeitamente que os lúbricos impulsos, que dantes lhe inspirava a graciosa rapariga, iam-se agora destecendo e dissipando à luz de um novo sentimento de gratidão e respeito".

\footnotetext{
${ }^{94}$ CP, 1977 , p. $55-56$.

95 Ibidem, p. 112.
} 
Com isso: "A primitiva Amélia desaparecia aos poucos, para dar lugar àquela extremosa criança, àquela irmãzinha venerável [...]".

Se tomarmos emprestado o que José de Alencar denomina "mercado matrimonial" para caracterizar os interesses de Amélia, Coqueiro e Mme. Brizand, podemos dizer que para Amâncio isso significa um envolvimento puramente circunstancial, estimulado pela liberdade recebida dos donos da casa de pensão. A sala é penetrável - os quartos são utilizados para romances libertinos. A habitação coletiva se apossa de todo espaço da intimidade familiar. Ninguém se casa. A instituição do casamento fica em segundo plano.

A seqüência 20 ( $2^{a}$ coluna) descreve as primeiras impressões que Amâncio tem de Lúcia. Apesar de descrevê-la de um modo que se assemelha ao grotesco, a linguagem empregada é extremamente formal: "Ao lado dele assentou-se gravemente a Lúcia Pereira. Amâncio envolveu-a em continente num olhar extenso e observador [...]". Então é descrita como uma mulher: "de estatura regular, costas levemente arqueadas, ombros erguidos, como por uma forte impressão de medo: braços descaídos, cintura pouco abaixo dos seios, desenhando muito a barriga, que não era pequena".

O conteúdo registrado no livro ${ }^{96}$ é apresentado de modo mais direto: "E voltou o olhar a sua direita, onde Lúcia acabava de tomar assento. Examinou-a logo, à primeira vista, sem o dar a conhecer, e a impressão recebida não foi das melhores [...]". Suas características físicas a definem como uma mulher: "de estatura regular, tinha as costas arqueadas e os ombros levemente contraídos, braços moles, cintura pouco abaixo dos seios, desenhando muito a barriga". É interessante esse olhar masculino sobre o corpo de Lúcia porque a gordura e falta de postura denotam falta de delicadeza, o que revela a visão naturalista do escritor.

Lúcia, principal rival de Amélia, é vista como uma pessoa com poucos escrúpulos e educação, apesar de ser culta. "Deram-lhe professores de francês, de música, de desenho; entregaram-lhe enfiadas de romances banais do gênero de Mistério da Tijuca e livros de maus versos; e, todavia, não Ihe deram moral, nem trataram de Ihe formar o caráter" (SEQÜÊNCIA 30, $2^{a}$ coluna). O livro suprime a menção feita ao romance-seriado Mistérios da Tijuca, publicado pouco tempo antes de Casa de Pensão. A metalinguagem significa uma forma de Aluísio dialogar com

\footnotetext{
${ }^{96}$ Ibidem, p. 64-65.
} 
os leitores dos romances-seriados, pois o livro não o cita. Sobre a função metalingüística, Jakobson (1970, p. 213-221) oferece a seguinte explicação:

\begin{abstract}
Cada vez que o destinador e ou o destinatário acha necessário verificar se eles utilizam bem o código, o discurso é centrado sobre o código: preenche uma função metalingüística (ou de crítica): 'não o estou a seguir - que quer dizer?' pergunta o ouvinte, ou, em estilo de realce: 'que se poderá dizer?'. O locutor, antecipando-se, inquieta-se: 'Compreenderam o que quero dizer?
\end{abstract}

Ironicamente, o mesmo Amâncio que descrevera os defeitos de Lúcia agora passava a desejá-la ardentemente: "E nada de vir o sono [...]. Desejava Lúcia, mas desejava que ela viesse naquele mesmo instante, que ela the aparecesse ali, no silêncio daquele quarto, enquanto o palerma do marido dormia lá em cima [...]" (SEQÜÊNCIA 31, 3a coluna). No entanto, parece que sempre tem alguém atrapalhando a vida de Amâncio. Primeiro foi o pai, depois o professor Pires, agora o palerma marido da Lúcia. A distância entre os quartos significa um obstáculo para Amâncio chegar até Lúcia. Na versão em livro, as palavras em negrito são suprimidas.

Na seqüência 40 ( $3^{\mathrm{a}}$. coluna), último segmento do romance-seriado, Lúcia senta-se "à beira da cama de Amâncio". Lúcia tenta seduzir o nortista "sacudindo romanticamente os cabelos, que ela trazia soltos sobre as costas, perguntou com ímpeto: [...]" (6 $6^{\mathrm{a}}$ coluna).

No livro ${ }^{97}$, ocorre um diálogo entre os amantes, no qual Lúcia pressiona Amâncio a tomá-la do marido:

- Eu?! - Sim, tu! E, assentando-se à beira da cama, para lhe ficar mais perto, continuou, diminuindo o tom da voz: [...].

E Lúcia, agitando romanticamente os cabelos, que ela por cálculo trazia soltos essa noite, perguntou com ímpeto: [...] (CP, 1977, p. 115).

Como a publicação do romance-seriado foi interrompida antes de Amâncio definir se ficaria com Amélia ou Lúcia, ou se ainda lutaria pelo amor de Hortênsia, o final da seqüência quarenta estabelece um grande corte e instaura suspense à intriga de Casa de Pensão.

\footnotetext{
${ }^{97}$ Ibidem, p. 114.
} 


\subsubsection{A figura masculina}

\subsubsection{A voz do pai: o odioso Vasconcelos}

O ódio que Amâncio sentia pelo pai pode ser exemplificado pela "voz grossa e insociável" que lhe atormentava quando fazia algo que o pai não aprovaria. Como era de costume, Amâncio ficava muito agitado quando freqüentava festas e, ao voltar do baile dado na casa do Melo, não conseguindo dormir, começou a pensar em ternos episódios de amores fáceis até lhe surgiram pesadelos com o pai. $\mathrm{Na}$ seqüência 28 ( $5^{\mathrm{a}}$. coluna), destacamos detalhes que somente estão presentes na variante folhetinesca. Amâncio é atormentado pela voz do pai, dizendo-lhe:

\footnotetext{
- Anda daí, mandrião! Basta de cama! Vê se queres que eu te vá buscar! E aquela voz terrivel dava-Ihe a todo o corpo tremor de medo. Não podia suportar aquele homem! Aquele maldito velho Vasconcelos, que no sonho não lhe aparecia como pai, mas como um senhor mal, bruto. Aquela voz grossa e insociável, vultos cor de rosa, de cabelos louros, fugiam espavoridos, para os lados e sumiam-se rapidamente, como rãs que se atiram n'água, assustadas pela presença de um boi.

No mesmo instante achava-se a sós com a maldita voz, que se condenava, formando nuvens negras e pesadas. Queria gritar, correr, mas a língua inchava-Ihe na boca e as pernas pareciam troncos de árvores, seguras ao chão.

Acordou muito fatigado e aborrecido às duas horas da tarde.
}

$\mathrm{Na}$ variante em livro ${ }^{98}$, são suprimidos os detalhes destacados acima, relacionados ao pesadelo que a lembrança do pai despertava em Amâncio.

Quando Amâncio recebe a primeira carta do pai, uma nova imagem se configura. A seqüência 34 ( $4^{\mathrm{a}}$ e $5^{\mathrm{a}}$ colunas) relata que: "Sentia certo gostinho em merecer aqueles conselhos de amigo íntimo [...]. Agora apareciam remorsosinhos penetrantes, como se o pobre rapaz contribuísse de qualquer modo para a insuficiência do seu amor". O livro ${ }^{99}$ apresenta esta reflexão diretamente: "Desfrutava um certo gosto em merecer aquela intimidade paterna; mas, por outro lado, doía-lhe a consciência por não ter sido melhor filho; como se o pobre rapaz de qualquer forma contribuíra para semelhante falta".

\footnotetext{
${ }^{98}$ CP, 1977, p. 84-85

99 Ibidem, p. 99.
} 


\subsubsection{Coqueiro}

A habilidade que Aluísio tinha com os pincéis também pode ser vista nos contornos traçados por sua pena. Ao retratar a sociedade como se estivesse desenhando um quadro, a linguagem que constrói a caricatura de alguns de seus tipos é capaz de alcançar a redução do aspecto humano ao animal e, assim, como os aspectos físicos, a imagem moral também sofre deformação. Brayner (1979, p. 142) ressalta que o: "Sensacionístico por excelência, o artifício caricatural constrói a maioria dos personagens, numa redução do humano, ora acentuando os aspectos analógicos com o mundo animal, ora visando a agravar a inversão comum traço grotesco rebaixador e concreto".

A seqüência 09 ( $5^{a}$ coluna) relata que o antagonista Coqueiro ouvia Amâncio "com muita atenção, em silêncio". Enquanto Paiva e Amâncio estavam tontos, ele observava os colegas, "seus olhos, pequenos e de cor incerta, conservavam a mesma penetração e a mesma fixidez incisiva. Sua boca quase sem lábios e guarnecida de bons dentes tinha o mesmo riso arqueado, indeciso e frio". A descrição caricata é aprimorada no livro, o que ressalta a intensificação do discurso naturalista de empregar características zoomorfizantes, ou seja, a animalização do comportamento e traços humanos. Dessa forma, a citação a seguir destaca as alterações constatadas na passagem do conteúdo para o formato de livro:

\footnotetext{
Coqueiro estudava-o de socapa, a seguir-Ihe os gestos, a fariscar-Ihe as intenções. Dos quatro, era o único que não estava tonto: seus olhos, pequenos e de cor duvidosa, conservavam a mesma penetração e a mesma fixidez incisiva de ave de rapina; sua boca estreita, bem guarnecida e quase sem lábios, tinha o mesmo riso arqueado, mal seguro e frio, de quem escuta e observa (CP, 1977, CP, p. 37).
}

Esse mesmo comportamento observador pode ser notado na seqüência 21 ( $4^{a}$ coluna), quando: "Coqueiro fingia acompanhá-lo [Amâncio] naquele entusiasmo, mas ria-se por dentro". Porque, na verdade: "O outro parecia-Ihe cada vez mais tolo". Na versão em livro ${ }^{100}$, o comportamento simulado de Coqueiro é alterado pela mudança do termo fingia para o sinônimo afetava.

Na seqüência $29\left(1^{\text {a }}\right.$ coluna $)$, como comportamento característico de fim de festa: "Parecia que Amâncio comunicara a todos o seu fastio e o seu cansaço.

${ }^{100} \mathrm{CP}, 1977$, CP, p. 67-68. 
Embalde tentava o Coqueiro distraí-los, lembrando fatos engraçados; ninguém o secundava". No livro ${ }^{101}$, por outro lado, a tentativa de Coqueiro animar Amâncio foi suprimida. A seqüência $36\left(1^{\text {a }}\right.$ coluna) também apresenta detalhes sobre o entusiasmo de Coqueiro, enquanto Amâncio se mostra apático:

Pelo caminho de casa, o Coqueiro não se fartou de elogiar as boas maneiras e a franqueza do Campos; falou respeitosamente da amabilidade de Hortênsia, disse que Ihes havia de fazer uma visita em companhia da mulher e de Amelinha. E terminou dando ao colega conselhos referentes aos interesses do estudo, ao modo como se devia conduzir na sociedade, como deveria evitar os mil perigos da corte e a atitude que lhe convinha tomar em certas e determinadas conjunturas.

Amâncio ouvia-o distraidamente; já o aborreciam tantos conselhos.

- Ora bolas! todos o queriam guiar! e a insistência [...].

Nos destaques acima, o negrito enfatiza o conteúdo que apenas existiu no romance-seriado, o sublinhado ressalta a tentativa de Coqueiro incorporar a voz paterna, o que irritava Amâncio. No livro ${ }^{102}$, esse episódio não merece muito destaque, pois consta que: "Quase nada conversaram pelo caminho. Amâncio parecia aflito por se meter na cama; uma vez, porém, recolhido ao seu novo quartinho do segundo andar, não sentia a menor disposição para dormir [...]".

Em continuidade, a seqüência 36 ( $2^{\mathrm{a}}$ Coluna) revela que Amâncio apresenta certa preocupação por não se dedicar aos estudos: "[...] no mesmo ponto, como que encarecia a sua espécie de remorso pelo mau cumprimento das obrigações", mas, por mais que tentasse, dormia antes de conseguir assimilar uma só página do seu manual de Medicina, ou então começava a pensar em Lúcia e fechava o livro. Os impulsos que dominavam Amâncio também o afligiam no dia em que: "Chegaram a casa às quatro horas da manhã. Coqueiro recolheu-se logo e o outro subiu ao quarto, sem a menor disposição para dormir". Afinal de contas, a "idéia de que Lúcia estava ali perto a quatro ou cinco passos, mas inteiramente fora de seu alcance o torturava como uma injustiça clamorosa erguida contra o seu amor". No livro ${ }^{103}$, por outro lado, a curta distância que separava Amâncio de Lúcia, representava uma "pirraça levantada com o fim único de o afligir".

Seguindo a mesma perspectiva descritiva com que foi apresentado Amâncio, como produto do meio e das experiências, o antagonista João Coqueiro também é focalizado em sua meninice débil. A seqüência 14 ( $2^{\mathrm{a}}$ coluna) fala do amor

\footnotetext{
101 Ibidem, p. 85.

${ }_{102}$ Ibidem, p. 103.

${ }^{103}$ Ibidem.
} 
incondicional que a mãe tinha pelo "primeiro filho - Juca. Criancinha feia, sem sangue, cheia de asma. Até os cinco anos parecia idiota; passava os dias a babarse debaixo da mesa de jantar ao pé do moleque que tomava conta dele". O livro ${ }^{104}$ não apresenta alterações significativas, limitando-se a trocar o epíteto Juca por Janjão, sangue por dessangrada, reformulando, também, a parte final, na qual descreve que o menino: "passava os dias a babar-se debaixo da mesa de jantar, ao pé de um moleque encarregado de vigiá-lo".

Dando seqüência à apresentação de acontecimentos que marcaram a infância do antagonista, o romance-seriado, seqüência 14 ( $5^{\mathrm{a}}$ coluna), dá pouca ênfase ao fato de Coqueiro brincar com armas de brinquedo, o livro ${ }^{105}$ ressalta que o antagonista recebera do pai "uma bela pistolinha de brinquedo, que estalava fulminante, e depois uma outra, mais séria, que admitia carga de pólvora". Os termos em destaque evidenciam a ação das leis deterministas de que o homem é produto do meio em que vive, portanto, o fato de Coqueiro brincar com armas de fogo na infância pode tê-lo influenciado no momento em que decidiu assassinar Amâncio à queima roupa, em uma emboscada.

\subsubsection{Campos, o comerciante íntegro}

Distante do Brasil e dos amigos, Aluísio encontrara nas cartas uma maneira de obter informações das transformações ocorridas em seu país e um meio de thes solicitar favores. No dia 23 de outubro de 1903, escreve de Salto Oriental ao "Querido Florindo": "Fala-me tua carta das transformações que vai sofrer o Rio de Janeiro, e a leitura que tenho feito dos jornais do Rio, confirmando tuas palavras, produzem em mim o mais singular efeito que é possível imaginar". As informações apresentadas por Florindo, somadas àquelas lidas em jornais cariocas, pareceriam corroborar as mudanças que a Corte passaria naquela época e se intensificaria nas décadas seguintes. No entanto, mesmo com tantas evidências, Aluísio ainda tentava encontrar argumentos que o fizesse acreditar que isso não aconteceria, então perguntava ao amigo:

\footnotetext{
${ }^{104}$ Ibidem, p. 47.

105 Ibidem, p. 48.
} 
Será com efeito possível que o Rio de Janeiro perca o seu velho feitio colonial português e dê em capital sadia e limpa, com avenidas arborizadas e casas com estilo? Na mesma carta, Aluísio revela que não lê tais notícias sem pensar logo no Bilac, porque aí, quando andávamos juntos por essas ruas cor de tijuco e cheiro de vasilhame sujo, levávamos a reconstruir platonicamente toda a cidade, arrasando quarteirões, furando bairros, abrindo praças e até dando reviravoltas nas casas como se elas fossem de brinquedos (destaque nosso).

E é pensando em seu amigo Bilac que antecipa: "Vou escrever uma carta ao Olavo a esse respeito, sem falar que, a meu ver, ele é dos que mais tem contribuído moralmente para a grande revolução estética do Rio ${ }^{106 " .}$

Logo no início do romance Casa de Pensão, quando o narrador apresenta a primeira cena, que se dá com o encontro de Amâncio e Campos, amigo de sua família, a descrição da residência do comerciante relembra aquelas de "velho feitio colonial português" descritas acima. A seqüência 01 ( $5^{\text {a }}$ coluna) informa que a "casa comercial de Luís Campos era na rua Direita. Um desses casarões do tempo antigo cujas paredes não dão idéia da cor que possuíam e cujo ar severo e concentrado diz ainda os rigores do velho comércio português". No livro ${ }^{107}$, a descrição da casa de Campos é alterada na parte final, e, por isso, é caracterizada como um "desses casarões do tempo antigo, quadrados e sem gosto cujo ar severo está a dizer no seu silêncio os rigores [...]".

Para atingir seu objetivo de retratar fielmente a realidade, o escritor naturalista liga as características arquitetônicas à integridade de Campos. Esse viés dá-nos a impressão de que as escolhas são moldadas pelo meio e as sensações dele resultantes. Apesar de o ambiente condicionar grande parte dos personagens de Casa de Pensão, Campos foge à regra e não apresenta mudanças em seu comportamento. Por isso, destacamos que existe uma nítida relação entre o casarão, aos moldes daqueles "do tempo antigo, quadrados e sem gosto" e a postura conservadora de seu proprietário.

Enquanto o romance-seriado, seqüência 01 ( $5^{\text {a }}$ coluna) enfatiza que: "Apesar de brasileiro, Campos nunca conseguiu espantar de sua casa o ar triste que a ensombrecia", o livro ${ }^{108}$ adjetiva a nacionalidade de Campos, pois não se trata de um cidadão qualquer, isto é, antes ser mencionado o adjetivo pátrio, insere-se

\footnotetext{
${ }^{106}$ O Touro Negro, 1961, p. 204-205.

107 Op Cit, p. 14

${ }^{108}$ CP, 1977, p. 14.
} 
"inteligente", que o distingue dentre todos os personagens de Casa de Pensão, embora não seja suficiente para espantar o ar triste de sua casa.

Como se distinguia da coletividade, composta por seres medíocres e acomodados, Campos tinha seu modo de vida, guiado por projetos capazes de fazêlo progredir: "Amaldiçoado por uns, bem ausentado por outros, ora elogiado, ora mal falado, mas sempre a caminhar, sempre a prosperar" (SEQÜÊNCIA 02, $4^{a}$ coluna). Os meios que o personagem encontrará para o êxito profissional não ficam claros no livro ${ }^{109}$, porque: "[...] o caso era que Campos, ou devido à fortuna ou ao bom tino para os negócios, prosperava sempre". Diferente do livro, o romance-seriado descreve com mais detalhes, não apenas a apresentação de Campos, mas também de outros personagens e elementos constitutivos da narrativa e, por isso, a variante em jornal apresenta ritmo lento e linguagem minuciosa. Isso se deve ao fato de a linguagem naturalista valorizar a clareza, simplicidade e exatidão das descrições, como quem desenha um quadro rico em detalhes, a fim de impedir que não se veja o que não fora retratado. Se, por um lado, o livro apresenta a predominância de períodos curtos, favorecendo o entendimento literal, por outro lado, o romance-seriado apresenta especificidades direcionadas aos leitores dessa variante, que podem ter acompanhado a Questão Capistrano e o progresso urbanístico, que marcaram as duas últimas décadas do século XIX. Em meio a tantas transformações, à época de Casa de Pensão, grande parte dos leitores ainda preferia a literatura romântica, talvez, por isso, a linguagem híbrida seja menos evidente no livro.

\subsubsection{O homem-objeto}

Tanto o escravo Sabino quanto o marido de Lúcia não têm voz. Eles representam o silêncio daqueles que vivem à margem da sociedade. Sabino foi um presente dado pela avó. Ele tomava conta de Amâncio no Maranhão e o acompanhou quando este se mudou para o rio, no entanto, da mesma forma que o dono, Sabino também se entregou à boemia carioca.

O marido de Lúcia era um ser apático, desleixado, quase um vegetal. Sempre que tentava expressar sua opinião, sua mulher o insultava, obrigando-o a ficar

${ }^{109}$ Ibidem, p. 16. 
calado. Diante de insistências e provocações: "Ele, porém, não dava resposta, e, quando a mulher insistia a muito nas suas recriminações, fechava os olhos" (SEQÜÊNCIA 20, $3^{a}$ Coluna). No livro ${ }^{110}$, é inserido o mundo subterrâneo criado pelo personagem como saída para esquivar-se dos insultos da mulher. Dessa maneira, "[...] quando a mulher insistia, cerrava os olhos como se fugira para dentro de si mesmo".

A seqüência 39 ( $5^{\mathrm{a}}$ Coluna) revela um momento em que Lúcia pressiona o marido para saber onde ele havia gasto os cinco mil-réis que ela lhe dera no dia anterior: "Pereira explicou como tinha gasto o dinheiro. Não fora por culpa sua Passara por uma confeitaria na rua do Ouvidor... Alguns amigos o chamaram e, ofereceram-Ihe cerveja e doces. Aceitou, mas depois os $\left[. .{ }^{111}\right]$ foram-se embora, e ele teve de pagar". De forma sintética, no livro ${ }^{112}$ consta que: "Pereira explicou que os havia gasto contra a vontade, porque uns sujeitos o obrigaram a pagar cerveja e doces numa confeitaria".

\subsection{As vozes e os elos}

A sobreposição de vozes, entre o que Amâncio expressa e o que o narrador formula sobre os personagens nas duas esferas do romance, instaura duas forças discursivas. Conforme estabelece Bakhtin (1988), no que tange ao aspecto interacional da linguagem no texto literário, o estudo do discurso dialógico possibilita identificar posicionamentos sobre questões sociopolíticas, reproduzidas no universo diegético ficcional. A ambivalência da voz do narrador, que se dedica, principalmente, à descrição de Amâncio e que lhe cede espaço para expressar seu ponto de vista, instaura a plasticidade da voz narrativa e dramaticidade às cenas. Essas duas vozes conferem pluralidade ao discurso narrativo de Casa de Pensão, abrindo-o, na medida em que apresenta o horizonte plural da linguagem literária. A análise do texto e do contexto, na atmosfera e na relação comunicativa, denota que a produção de sentido em Casa de Pensão considera a relação entre escritor e leitor, aspectos do discurso sócio-histórico.

\footnotetext{
${ }^{110}$ CP, 1977, p. 65.

111 llegível.

112 Op Cit, p. 112
} 
O romance-seriado cria o cenário e apresenta as personagens, cujas vozes podem ser relacionadas àquelas que dizem respeito à Questão Capistrano, que ainda estão vivas na mente de muitos leitores contemporâneos à variante do jornal. Para a composição do livro, o conteúdo passa por revisão: a nota que sumariza o romance-seriado é retirada; há alterações de ordem gramatical e estrutural; algumas marcas do discurso indireto livre são suprimidas. Amélia, por exemplo, que no romance-seriado parecia reflexiva e contrária à pressão exercida pelo irmão e pela cunhada para convencê-la a seduzir Amâncio, no livro o narrador não descreve esse sentimento, colocando-a como um ser passivo que aceita o que lhe é imposto:

A ficção do fluxo da consciência ao usar técnicas como as do monólogo interior, direto ou indireto, o solilóquio ou a descrição dos estados psíquicos feita por um narrador onisciente, entre outras, não pretendeu apenas reformar o conhecido discurso interior da ficção. Invertendo o nível da comunicação racional e controlada de um personagem tomado como unidade reflexiva, abre mão da análise psicológica e penetra nos domínios mais indevassados das manifestações psíquicas, na fluidez contínua das sensações, fantasias e aspirações, a fim de desvendar os fatos da consciência em contato com os fatos sociais, ambos de percepção fragmentária - $\mathrm{a}$ atomização da realidade convoca o indivíduo a valer-se de um enfoque cada vez mais subjetivo (BRAYNER, 1979, p.180).

Caracterizando o modo de pensar da época, a personagem do romanceseriado parecia tentar contrariar o que é dito à sua homônima em o Jornal das Famílias (16 jul. 1878):

\footnotetext{
"Amélia"

Um namoro velho, minhas leitoras, é muito prejudicial às moças, porque se o namorado por qualquer circunstância deixa de casar, nenhuma outra pessoa se anima pedi-la, se não pelo receio de uma recusa formal, ao menos pela bem fundada suspeita de que ela possa ainda sentir algum tictac de tempos passados.

Assim é que d'estas delongas resulta muitas vezes o alistamento de mais uma praça para o batalhão das involuntárias tias!
}

Além de condensar parte das informações que poderiam traçar o perfil psicológico dos personagens, a versão em livro apresenta parágrafos mais sintéticos; capítulos são suprimidos enquanto outros se fundem. Mesmo sem apresentar a história na íntegra, pois é interrompida antes do clímax e desfecho, o romance-seriado desvenda os principais elementos da narrativa, tais como: tempo psicológico (marcado por analepses) e cronológico, apresentação do espaço, personagens e conflitos. 
O livro apresenta três grandes núcleos ou direções da diegese. A primeira corresponde ao conteúdo publicado no romance-seriado, com a história da vida em casa de pensão e a construção do caráter dos personagens, delimitação do espaço e as analepses do tempo, que são projetadas pela saudade que Amâncio sente do Maranhão e retomam a ordem cronológica no espaço do Rio de Janeiro, na medida em que o personagem se convence da necessidade de entregar-se à vida libertina $e$ ao caso com Lúcia, ao mesmo tempo em que revela sua falta de vocação para os estudos. A segunda acrescenta novos núcleos para a história, tais como o envolvimento de Amâncio e Lúcia e as estratégias de Coqueiro e Brizard para tirá-la do caminho, a fim de favorecer as investidas de Amélia, até que esta consegue seduzir o pensionista e, mesmo sem casarem e Amâncio ter certeza de que seu verdadeiro amor é Hortênsia, vão morar em um chalé. A terceira focaliza a surpreendente aprovação de Amâncio no primeiro ano da Escola de Medicina, mesmo sem ter empenhado esforços para isso; depois disso, Amélia lê a carta de amor que Amâncio havia escrito à Hortênsia e o medo de Amâncio fugir do compromisso impulsiona-a a entregar a carta ao irmão, que, por sua vez, abre um inquérito contra Amâncio. Depois de vê-lo absorvido, Coqueiro se desespera e assassina o colega como forma de restabelecer a honra à irmã.

A versão em livro representa a conclusão do projeto que fora descrito na nota Antes de principiar, na véspera da publicação da primeira fatia de Casa de Pensão, ao mesmo tempo em que revela o ponto de vista do escritor naturalista sobre a Questão Capistrano, aludida na história do romance. 


\section{CONTEXTO DO PROCESSO DE CRIAÇÃO}

No universo artístico que compreende o processo criativo de Casa de Pensão, jornalismo e literatura representam duas modalidades que estão profundamente associadas, seja no momento de selecionar informações a partir de notícias, na elaboração das vertentes do romance e na divulgação das mesmas. Essa estreita relação contribuiu para que os discursos se fundissem, resultando em uma nova linguagem, híbrida, entre literatura e jornalismo. Nesse aspecto, em Casa de Pensão (1883-1884), há o retrato pessimista e, ao mesmo tempo, revelador do cotidiano em casas de pensão do Rio de Janeiro, apresentado no mundo do texto.

$\mathrm{O}$ fato de a origem de Casa de Pensão estar profundamente relacionada à linguagem e a notícias registradas no meio jornalístico, possibilita um diálogo entre arte e experiência, na medida em que a ficção incorpora informações lidas e assistidas pelo autor e pelos leitores contemporâneos à obra de arte. Como resultado, temos um limite, por mínimo que seja, "como um cristal que separa dois ambientes; e a percepção de fronteira é testada pela consciência do escritor, enquanto testemunha. Ele sabe que o objeto da sua escrita é a sua experiência, e é uma experiência que ele pode atestar, empiricamente verificável: o real que aconteceu" (BOSI, 1997, p. 12).

Se pensarmos a partir dessa ótica, chegaremos à conclusão de que Aluísio assumiu o plano da memória ao retomar um acontecimento assistido por ele e por muitos leitores que Ihe eram contemporâneos. Ao analisar as notícias transmitidas pela imprensa, podemos detectar algumas das informações absorvidas pela ficção, bem como delinear a trama criada pelo autor, com a finalidade de retratar a sociedade assistida no movimento do cotidiano carioca desse período. Da mesma forma, os leitores, dependendo da proximidade que tiveram da Questão Capistrano, puderam identificar em que momentos o ficcionista "mentiu", ou seja, quando a ficção insere informações ligadas às notícias e quando a narrativa apresenta elementos criados pelo autor.

Por outro lado, por mais que o romancista inclua na ficção fatos que dialogam com registros jornalísticos, pressupomos que esses episódios passam pelo viés interpretativo do autor, por intermédio do qual se torna possível filtrar o conteúdo a 
ser romanceado. Depois desse procedimento, ainda que o quantum do real histórico seja cogitado, o modo de trabalhar, que é essencial à criação literária, é ficcional. Nessa perspectiva, podemos dizer que Aluísio não teria mentido, mas criado:

\footnotetext{
O romancista não mente nunca, porque ele efetivamente mexe com representações da imaginação que podem, ou não, ter um conteúdo empírico historicamente atestado. Mesmo que maciçamente seja documentado o fato que ele está contando, o regime do texto no seu conjunto é de ficção (BOSI, 1997, p. 13).
}

Em continuidade aos apontamentos realizados por Alfredo Bosi (1997, p. 14), no entanto, sem descartar outras especulações sobre esse nó teórico [entre a separação de ficção e não-ficção], parece-nos pertinente dizer: "que ao fazer discurso histórico ou memorialista, a consciência autoral sabe que há momentos que são puras transcrições jornalísticas do acontecimento e momentos em que opera toda uma fenomenologia do desejo e em que entram elementos imaginários". Portanto, é válido observar que é nessa fronteira que ocorre o hibridismo discursivo e se efetiva a construção discursiva de Casa de Pensão.

Ao apresentarmos a Questão Capistrano, em um conjunto de "transcrições jornalísticas", a partir das publicações do Jornal do Comércio e da Gazeta de Notícias, também podemos constatar nesses registros noticiosos elementos característicos de apresentações literárias, como se a reportagem tivesse em sua essência características semelhantes às das crônicas, porque ambas brotam do cotidiano.

Como a produção artística de Aluísio Azevedo estava inserida no mercado editorial do jornal e livro, o autor declarava-se atento aos temas que poderia encontrar na atmosfera do meio jornalístico, levando em consideração o interesse do público, a exemplo das notícias sobre a morte de Capistrano. Essa escolha pelo noticioso poderia significar ao autor um vôo maior, tanto no que tange ao aspecto social quanto político. Outra justificativa pode estar relacionada ao fato de a notícia representar novidade para o período, ou seja, ela está ligada ao que a opinião pública da época define como informação nova, no sentido de atualidade. Atento às perspectivas que moviam o interesse do público e as transformações da mídia, Aluísio também se mostra atento para acompanhar o momento em que os jornais e a literatura dialogavam cada vez mais próximos, por isso, Aluísio recolhe o material dos jornais e cria Casa de Pensão. 
Com o projeto literário traçado, o Jornal do comércio e a Gazeta de Notícias podem ser classificados como sistemas semióticos modelizantes por conferirem parâmetros interpretativos aos leitores do período, dentre os quais poderia se inserir Aluísio Azevedo, que chegou ao Rio de Janeiro no mesmo ano da Questão Capistrano.

Apesar de termos consciência das inúmeras possibilidades de explorar as informações jornalísticas, ressaltamos que o objetivo apresentado neste estudo nos limita à focalização do eixo que une as notícias ao contexto do processo criativo de Casa de Pensão, no intuito de perceber de que modo Aluísio entendia as mudanças de perceptiva, advindas dos efeitos das tecnologias sobre os indivíduos. Por isso, o diálogo intertextual torna-se essencial para apresentar os conflitos do romance, ao mesmo tempo em que registra os conflitos socioculturais do período.

A partir dessa contextualização basilar, podemos pressupor que Casa de Pensão é a materialidade de um acontecimento, transformado em texto na medida em que o distanciamento temporal concede ao escritor condições de construir, por intermédio da ficção, um horizonte capaz de fundir linguagens vinculadas a meios de produção distintos.

Com o material em mãos, ao escritor é dada a tarefa de organizar as palavras, os acontecimentos assistidos, lidos ou ouvidos (atrás de uma porta ou de uma parede). Então, para produzir cada vertente do texto, ele escolhe um modo, constrói c enár i a dsp̃e seus per sonagens nos espaços traçados e elałrra as falas ligadas à temática, à vida em casa de pensão. Depois de tudo isso, surgem as tipologias, agrupadas ao mote arquitetado.

\subsection{Intertexto}

Dando seqüência à apresentação do contexto produtivo de Casa de Pensão, esta etapa apresenta elementos intratextuais e extratextuais, no intuito de caracterizar o ponto de vista do autor e o gênero de Casa de Pensão, em função da plurissignificação discursiva. O romance-seriado, publicado no jornal Folha Nova (1883), é a primeira versão do romance estudado, conforme pode ser verificado na 
nota Antes de principiar, considerada como nota introdutória ao romance, por apresentar particularidades sobre a publicação, em função das expectativas dos leitores e das vozes inerentes à temática abordada. Suprimido da variante em livro, o conteúdo da nota sumariza a diegese e cria um horizonte de leitura para o público que, a partir do dia seguinte a essa publicação, passaria a ter acesso aos segmentos que compõem o romance-seriado, os quais representam doze dos vinte e dois capítulos do livro.

No movimento criativo de Casa de Pensão, escrever sobre o gênero ou a pluralidade de vozes discursivas que compõem a trama do romance requer uma análise prévia sobre a origem do referencial que está associado ao seu pano de fundo. Como este estudo se detém ao contexto que abrange as décadas de 70 e 80 do século XIX, procuramos focar a Questão Capistrano, enquanto relato noticioso, para, posteriormente, concebê-la como elemento essencial para a construção de um texto ficcional plurissignificante. Nesse caso, como o processo criador abrange o período de 1883 a 1884, com o registro de dois momentos criativos, consideramos que o ponto de vista de Aluísio se alterna entre o literário e o informativo, entre o gênero do romance-seriado e do livro, a partir dos modos de ver, ligados à visão conceitual de um microcosmo da sociedade carioca.

Como nosso estudo analisa duas vertentes de Casa de Pensão, uma delas publicada em romance-seriado e a outra em formato de livro, acrescentadas, ainda, as notícias sobre a Questão Capistrano, faz-se necessário analisar alguns aspectos característicos dos textos jornalísticos, para delinear o diálogo da notícia com a ficção. Nessa perspectiva, encontramos em van Dijk elementos úteis para uma leitura da notícia enquanto discurso.

\subsection{A narrativa de Casa de Pensão: a voz e o ponto de vista}

Este estudo contempla o conceito de narrativa que Genette (1995, p. 24) diz ser o mais difundido: "sucessão de acontecimentos, reais ou fictícios, que constituem o objeto desse discurso, e as suas diversas relações de encadeamento, de oposição, de repetição, etc". Aplicando essa noção de narrativa ao romance em análise e ao referencial jornalístico nele marcado, se tomarmos por base analítica as 
duas categorias que podem ser consideradas como constitutivas da estrutura narrativa dos onze primeiros capítulos do romance-seriado, que correspondem aos doze primeiros do livro, a história real e a releitura da história real no texto fictício, devemos considerar que: a) apesar de a história real estar explicita nas duas variantes, há variações significativas de texto para texto; b) a variação não se refere apenas ao âmbito da apresentação, mas também no modo como os fatos são inseridos na trama; as escolhas textuais representam o modo como Aluísio textualiza a representação do mundo e o modo como expressa a sua identidade e a identidade do outro; c) essas escolhas textuais são estratégias ideológicas que revelam, não apenas o posicionamento do autor relativamente à história real, mas também as estratégias que usa para posicionar, de modo particular, os seus leitores e a exigência dos críticos. A nota introdutória à Casa de Pensão cede espaço para a voz de um "narrador confiável", cheio de boas intenções, que explica de modo pedagógico os motivos que o levaram à escrita desse romance-seriado. Direcionado ao leitor de romance-seriado, esse texto foi suprimido na versão em livro.

Como uma das intenções de Azevedo e da escola Realista-Naturalista era criar tipos que denunciassem a sociedade como um tecido adoecido, na parte final da nota introdutória, lançada no jornal Folha Nova na véspera da publicação da primeira seqüência do romance-seriado, Aluísio alerta o público leitor de que: "se descobrir em alguns dos meus folhetins qualquer cena de sua vida, queira de antemão perdoar-me semelhante coisa, porque em tal fato não haverá intenção de ofensa ou maldade", porque "os males reais só podem ser combatidos pela própria realidade". Esse paratexto que apresenta a modelização (ou modelo de mundo, segundo Lotman, 1978) de Casa de Pensão, aponta para a organização do material narrativo do romance-seriado e caracteriza a voz narrativa.

Os pressupostos apresentados por Aluísio Azevedo enfatizam que: "O papel de uma narração não é apenas informar sobre acontecimentos, mas mostrá-los de modo a prender nosso interesse" (CABRAL; MINCHILLO, 1991, p. 11). O empenho do escritor em caracterizar personagens e espaços conhecidos pelos leitores contemporâneos à publicação de Casa de Pensão pode dar vida aos seres fictícios dentro de seu universo narrativo:

Uma caracterização bem-feita é aquela que torna viva a presença das personagens na imaginação do leitor. [...] A caracterização de uma personagem pode ser feita pela descrição dos aspectos físicos, psicológicos 
e sociais, ou por suas ações. De qualquer modo, é necessário selecionar as características que sejam significativas para a unidade do texto, para a obtenção do sentido geral da narração.

A definição realizada por Genette ${ }^{113}$ sobre os tipos de narrador nos leva a crer que em Casa de Pensão há um narrador heterodiegético, ou seja, aquele que narra em terceira pessoa e, interagindo com os outros, tomará parte do corpo do romance, em que o autor saberá dar a devida importância a cada um dos personagens. No entanto, há um filtro narrativo entre a voz do narrador e do escritor que se torna mais evidente na variante em livro. O narrador de Casa de Pensão utiliza a nota para revelar a alma da diegese. Sua voz revela os propósitos, as denúncias e o ponto de vista assumido. Esses aspectos também podem caracterizar o perfil dos leitores potenciais e a capacidade que eles têm de interpretar o romance-seriado.

Podem ser encontradas analogias entre a nota Antes de principiar, na qual se encontra o ponto de vista de Aluísio, e aquela definida por Flaubert: "Depois da falência de todos os ideais, de todas as utopias, a tendência agora é manter-se dentro do campo dos fatos, e de nada mais do que de fatos". Como a ficção tem o poder de transpor para o texto literário, dramas extraídos do cotidiano, Aluísio antecipa o fio basilar de seu novo romance e pormenores que irão culminar o conflito central da diegese.

Nesse sentido, a nota que antecede a publicação do romance-seriado Casa de Pensão, apresentando o posicionamento de Aluísio Azevedo pelo viés do texto literário, como um modelo de mundo. Criada pelo autor-emissor e direcionada ao receptor-leitor, contemporâneo à publicação dessa variante, a mensagem é o meio que o autor encontra para expor os motivos que o impulsionara à retomada de um tema polêmico, por isso prevê que os propósitos almejados com a escrita do romance somente serão efetivos se houver aceitação de um determinado número de convenções. Segundo Aguiar e Silva:

Em relação ao emissor, o código literário constitui um programa, isto é, uma série de instruções e de operações ordenadas que lhe possibilitam praticar uma determinada escrita e produzir uma peculiar modalidade de textos, nos quais e através dos quais organiza de modo específico um modelo do mundo. Em relação ao receptor, o código representa também um programa que lhe permite ler, isto é, reconhecer e interpretar o texto literário como texto literário. (SILVA, 1983, p. 246).

${ }^{113}$ Cf. AGUIAR E SILVA, Vitor Manuel de (1983, p. 761-762). 
Sob o ponto de vista de Michael Riffaterre (1979, p. 7), "o fenômeno literário não é apenas o texto, mas também o seu leitor e o conjunto das reações possíveis do leitor ao texto - enunciado e enunciação. [...] O texto é um código limitativo e prescritivo".

No diálogo proposto pelo escritor de Casa de Pensão apresenta-se um painel temático familiar aos leitores da época, com a união dos códigos jornalístico e literário, Romantismo e Naturalismo, que resulta em um gênero híbrido em meio ao movimento criativo do romance. A tentativa de normalização da metalinguagem literária - pela nota que debate questões tratadas nos microcosmos das folhas diárias - expõe o pressuposto na lógica do código literário organizado para aquele momento e visando aos propósitos fixados por intermédio da ficção.

Para entender um pouco mais do efeito que esse drama causou na população carioca daquele período, retomamos a carta escrita no dia 27 de maio de 1883 e publicada no dia 02 de junho, sob o título Casa de Pensão, na qual Araripe Júnior indaga ao escritor: "se Ihe aprazia assanhar essa fera chamada - público, atirandoIhe pedaços de carne crua e ensangüentada, como costumam fazer os domadores, para mostrar mais realçadas as suas qualidades dominadoras". Segundo o crítico: "A resposta a estas e outras injunções foi o aparecimento de Casa de Pensão" (ARARIPE JR apud BOSI, 1978, p. 135).

Essa preocupação do crítico traz à tona o fato de que a notoriedade conquistada por Aluísio o colocava em evidência tanto perante a crítica quanto perante os leitores, sobretudo aqueles que acompanhavam seus romances-seriados. Por isso, o sucesso adquirido na variante para o jornal poderia garantir à publicação uma dimensão maior, em livro, garantindo ampla circulação e retorno financeiro significativo. O movimento criativo das versões do romance analisado estabelece relações com o apontamento de Bakhtin, no qual o semioticista russo enfatiza as alterações que um discurso pode apresentar, pois: "Na conversa mais desenvolta, moldamos nossa fala às formas precisas de gêneros, às vezes padronizados e estereotipados, às vezes mais maleáveis, mais plásticos e mais criativos" (BAKHTIN, 1992, p. 301).

O gênero de Casa de Pensão se caracteriza pelo seu conteúdo temático, a referência à Questão Capistrano, as estruturas composicionais específicas, em jornal e em livro e pelos recursos lingüísticos utilizados pelo autor. Apesar de o eixo 
narrativo ser o mesmo nas duas variantes, o estilo do autor sofre interferência dessas duas esferas comunicativas, caracterizando-as nas publicações.

Aplicamos as definições de Genette (1995), relacionados às versões de Casa de Pensão, nos seguintes aspectos da realidade narrativa: "história" refere-se ao significado atribuído ao conteúdo narrativo; "narrativa" designa o enunciado narrativo, "o discurso oral ou escrito que assume a relação de um acontecimento ou de uma série de acontecimentos", também concebido como o discurso ou texto narrativo que apresenta "a sucessão de acontecimentos, reais ou fictícios" contado por alguém; "narração" caracteriza-se como "a instância produtiva da enunciação" que imprime uma voz (a do narrador), que se distancia dos acontecimentos para narrá-los, estabelecendo uma relação temporal entre eles. Se, por um lado, Todorov propõe diferenciar a "narrativa como discurso" e a "narrativa como história", por outro lado, Genette emprega o termo diegese com esse duplo sentido (GENETTE, 1995, p. 23-25).

Como a metodologia proposta por van Dijk (1990) abrange a análise de diferentes níveis do discurso, em diferentes sistemas semióticos, utilizamos esse procedimento para o estudo de documentos relacionados ao jornalismo e à literatura e demais elementos relacionados ao contexto produtivo de Casa de Pensão.

Sobre o discurso jornalístico, Vivaldi (1979, p. 353) observa que a reportagem [que compõe o pano de fundo do romance focado] apresenta a informação com maior liberdade de exposição na ordem do trabalho; define-a como um texto no qual se tem um relato informativo e também um relato narrativo mais ou menos noticioso, tendo, portanto, aspectos duplamente pertencentes à técnica informativa e à narrativa, como crônica do cotidiano.

Sendo assim, o que ocorre com a referência noticiosa quando o discurso se torna texto? No discurso oral, nas transcrições de falas da população que permearam a Questão Capistrano, isso se resolve no assunto ostensivo do discurso, pois aquela era uma realidade comum aos interlocutores do romance-seriado. Como os registros extraídos de jornais da época conferem a referência última desse discurso, há uma ruptura com a linguagem cotidiana e as técnicas jornalísticas sistematizam as informações.

Em Casa de Pensão, ficção publicada sete anos depois da morte de Capistrano, a realidade se metamorfisa em favor de que a literatura opera sobre um fato. No entanto, "o ter-sido é problemático, na medida exata em que não é 
observável, quer se trate do ter-sido acontecimento, quer se trate do ter-sido do testemunho. A passadidade de uma observação no passado não é ela própria observável, mas memorável" (RICOEUR, 1995, 274).

Em continuidade, Ricoeur acrescenta que as construções da história são representações que pretendem reconstruir, objetivamente, o passado que ficou para trás, representando-o por intermédio da ficção. Nessa perspectiva, Casa de Pensão, pode ser caracterizada como uma narrativa historiográfica, na medida em que as categorias de representância ou lugar-tenência permitem que a ficção procure reconstruir a história, atribuindo-Ihe significância. Ricoeur (1995) ressalta que a ficção representa a vida cotidiana. Nesse contexto, às práticas cotidianas, a ficção tem a função de revelar características implícitas, expostas explicitamente pelo viés da narrativa. Se, por um lado, é a narrativa que nos comunica os acontecimentos que descreve, por outro lado, também informa o meio que a traz à tona, ou seja, o conhecimento direto ou indireto, por intermédio do discurso da narrativa. Quando Aluísio se apresenta e expõe seu plano composicional, também imprime o ponto de vista assumido ao recontar um fato retirado do cotidiano, por isso deixa explícitas essas marcas autorais:

Amanhã o leitor encontrará neste canto mal aproveitado da 'Folha Nova' o primeiro folhetim do meu novo trabalho - Casa de Pensão. Além disso: Não o qualifico de romance, porque tal não é o caráter que lhe tenciono imprimir. Não tenho igualmente a pretensão de fazer dele um livro acientífico (sic), nem tão pouco realizar uma obra de arte. Apenas me proponho estudar uma das faces mais características e mais antipáticas de nossa sociedade a vida em casa de pensão ${ }^{114}$.

O posicionamento do autor parece essencial para o estabelecimento de um diálogo com os leitores e uma oportunidade de expor as motivações que o levaram à escrita desse romance. Por trás dessa nota, há a preocupação de Aluísio em expressar que a leitura de Casa de Pensão é uma atividade necessária para que a produção artística cumpra sua missão, pela representação de um drama histórico. No entanto, o excerto acima nos alerta para o que Genette (1995) caracteriza como dificuldade em se respeitar a autonomia do processo de produção do discurso narrativo, ou em reconhecer a sua especificidade, correndo o risco de se restringir a instância narrativa àquela exposta pelo autor, ou seja, ao que Aluísio escreve na

${ }^{114}$ Nota Antes de principiar. Folha Nova - RJ, 05 de março, 1883. 
nota Antes de principiar. Genette destaca essa possível identificação entre autor e narrador em narrativas de cunho histórico e em "biografias reais", o que nos motiva a tentar identificar essa aproximação nos textos que compõem o corpus deste trabalho, como uma forma de entender a relação do escritor com seu público.

\subsection{Gênero ou a pluralidade discursiva de Casa de Pensão}

Quando Mikhail Bakhtin (1992) enfatiza o caráter social dos fatos de linguagem, concebe o enunciado como o produto da interação social, que tanto pode consistir-se em uma situação material concreta, como pelo contexto mais amplo que constitui o conjunto das condições de vida de uma dada comunidade lingüística. Se aplicarmos o conceito de Bakhtin ao contexto criativo de Casa de Pensão, podemos entender que o discurso ficcional revela modos de interação social, que pode encontrar na Questão Capistrano um de seus registros materiais mais importantes.

Quando aplicamos esses conceitos bakhtinianos para caracterizar o enunciado de Casa de Pensão, como o produto da interação social, podemos dizer que os elementos derivados dos gêneros de discursos primários, também classificados como livres, são aquelas informações registradas pelos jornais, na medida em que transmitem o cotidiano dos espectadores nas entrelinhas da Questão Capistrano. O impacto que esse acontecimento provocou em suas vidas pode ser medido pela informação registrada por jornais de grande circulação, de que, aproximadamente, duas mil pessoas acompanharam o enterro de Capistrano. Nessa fração da população carioca, possivelmente existiam pessoas que mantinham uma relação imediata com as situações nas quais o discurso jornalístico era produzido e, portanto, o discurso noticioso imprime essas vozes, ao mesmo tempo em que registra o ponto de vista do periódico. No plano de Casa de Pensão, os gêneros de discursos secundários caracterizam-se pela linguagem verbal que recupera e registra os discursos primários e, a partir disso, a escrita perde sua relação direta com a Questão Capistrano e adquire a característica de linguagem referencial, que transcende os limites do tempo e do espaço, pela literatura.

Para compreendermos o nível referencial contido no romance estudado, precisamos analisar as marcas de tempo espaço, ou seja, o cronótopo narrativo de 
Casa de Pensão. Essas características composicionais cronológicas podem ser encontradas quando a narrativa registra os espaços abertos que compreendem ruas do Rio de Janeiro, largos e o Jardim Botânico, o cais Pharoux; espaços fechados de estabelecimentos de ensino no Rio de Janeiro e no Maranhão, restaurantes, hotéis, lojas; o tempo que se remete ao calendário escolar. O diálogo entre ficção e o acontecimento tem em comum a apresentação dos espaços e o tempo que marca a rotina de Capistrano, estudante da Escola Politécnica e modelo de Amâncio.

Se observarmos a diversidade das atividades exercidas pelos diversos grupos que acompanharam a Questão Capistrano e a publicação de Casa de Pensão, poderemos citar a língua e a linguagem registradas nas produções literárias, no formato de romance-seriado (1883) e em livro (1884); as notícias transmitidas pelo Jornal do Comércio (1876) e pela Gazeta de Notícias (1876); as peças jurídicas descritas pelos periódicos; a língua usada no cotidiano carioca da segunda metade do século, dentre outros.

No Brasil, os dois primeiros recenseamentos foram realizados em $1872 \mathrm{e}$ 1890 (IBGE, 2007). Em decorrência da proximidade temporal da Questão Capistrano (1876) com o censo realizado em 1872, optamos pelas informações nele registradas, para caracterizar quais eram as principais atividades da população carioca desse período, no intuito de entender o perfil dos leitores da época. Em 1872, a população carioca era de 274.972 habitantes (em 1890, esse número seria praticamente duplicado, chegando a 522.651). Nessa época, grande parte dos trabalhadores masculinos pertencia à classe operária, enquanto a feminina se destacava no ramo da costura. Quando analisamos o número de leitores existentes no Brasil de 1872, deparamo-nos com a falta de informação sobre a população alfabetizada, pois apenas há o registro de que $84,4 \%$ da população brasileira eram analfabetos, de um total de, aproximadamente, 10 milhões de habitantes. Destacamos esse registro devido ao fato de que em algumas cenas de Casa de Pensão a personagem Amélia aparece cosendo, enquanto seu irmão Coqueiro trabalhou na estrada de ferro Pedro II, depois que os pais morreram.

O fato de a crônica ser um ponto de encontro entre o texto literário e o jornalístico confere à mistura de gêneros a possibilidade de atingir outro grupo de leitores em uma época que o analfabetismo era expressivo. Nesse aspecto, Susana enfatiza que "Martí parecia consciente de que o jornalismo permitia aos escritores o que não Ihe deparava o mercado dos livros: a democratização da escritura. É dizer, 
acesso a maior quantidade de público através de um instrumento no qual podiam trabalhar não só as elites, senão as classes médias" (ROTKER, 1991, p. 120).

Amalio Pinheiro, Doutor em Comunicação e Semiótica, destaca que:

\begin{abstract}
A mobilidade em mosaico do jornalismo impresso aproveitou-se, neste continente, de uma sorte de montagem sintática das "culturas em ritmo rápido", aptas para incorporar os agregados metonímicos provenientes dos mais diversos códigos e linguagens. Trata-se de processos de produção e recepção desdobrados, em interações múltiplas, pelo caráter migrante, mestiço e solar da sociedade. (AMALIO PINHEIRO, 2004, p. 13).
\end{abstract}

Nesse aspecto, as relações de hibridismo, como base de produção material da América Latina podem ser caracterizadas como modos de apresentar o mundo em transformação por intermédio de textos, cujos gêneros se ligam à literatura, do mesmo modo em que encontram em notícias transmitidas pelos jornais um panorama dos principais temas relacionados à organização da sociedade da América Latina, assim da Hispânica nas últimas décadas do século XIX. Os estudos vinculados a esse período revelam que os principais escritores e jornalistas tinham a preocupação de registrar essa tendência. Rotker, por exemplo, encontra nas crônicas de José Martin provas de que muitos dos escritores da América Latina sempre se aproveitaram desse meio híbrido.

Martín-Barbero (2001, p. 229) destaca que o século XIX foi cenário de um novo nacionalismo, no qual a cultura nacional sintetizaria a particularidade cultural e a generalidade política em expressões de diferentes culturas étnicas e regionais. $O$ autor acredita que analisar o espaço cultural significa focalizar o lugar onde se articula o sentido que a sociedade atribui aos seus processos políticos e econômicos.

No Brasil, Aluísio Azevedo acompanha esse movimento por retirar de notícias do cotidiano a matéria-prima para a composição de seus romances-seriados e, até mesmo, seus romances elaborados diretamente em formato de livro. Desse modo, Aluísio se encaixa na tese de que os grandes escritores nasceram da escritura para a crônica. A partir disso podemos confirmar que Aluísio acompanhou essa regra, ou seja, o hibridismo era uma condição necessária.

A reflexão sobre a necessidade de acompanhar o ritmo da modernidade, que já era percebida por Aluísio Azevedo, instaura: "O questionamento que as novas tecnologias produzem acerca das identidades culturais, opera assim, sobre 
diferentes registros, que precisam ser distinguidos" (BARBERO, 2001, p. 266). Nesses dois movimentos conflitantes:

\begin{abstract}
Um é o desafio que se impõe às tentativas de fuga para o passado, à velha tentação idealista de postular uma identidade cujo sentido se acharia na origem ou, de todo modo, lá atrás por debaixo, fora do processo e da dinâmica da história e da atualidade. Outro é o sentido assumido pelas novas tecnologias como ponto culminante da "operação antropológica", isto é, a reativação da lógica evolucionista que reduz, agora radicalmente e sem fissuras, o outro ao atrasado, que converte o que resta de identidade nas culturas diversas em mera identidade reflexa - não tem valor senão para valorizar pelo contraste, a identidade da cultura hegemônica - e negativa: o que nos constitui é o que nos falta, o que nos constitui é a carência. E o de que carecemos, o que mais nos faltaria hoje seria isto: a tecnologia produzida pelos países centrais, esta que nos vai permitir afinal dar o salto definitivo para a modernidade (MARTIN-BARBERO, 2001, p. 266).
\end{abstract}

Na época de Aluísio, a indústria cultural e o mercado editorial pareciam andar no mesmo ritmo. Por isso, cada esfera de atividade artística de Casa de Pensão possui particularidades relacionadas à linguagem do meio de publicação sem, no entanto, deixar de destacar as semelhanças, - que se justificam pela estreita relação entre essas duas atividades no séc. XIX. Por esse aspecto, as duas variantes de Casa de Pensão estão em um liame propício para o desenvolvimento de um gênero híbrido, ou seja, a partir de dois discursos, vozes emergem das esferas externa e interna do texto, ao mesmo tempo em que revela marcas do processo que transita do Romantismo para o Naturalismo, em uma comunhão que Aluísio Azevedo encontrava para satisfazer leitores e críticos, ao mesmo tempo em que procurava se adequar às evoluções tecnológicas.

No contexto específico das trocas simbólicas desenvolvidas a partir de uma dialética reiterativa entre o romance Casa de Pensão e a Questão Capistrano, os tipos de sociedade representados nas variantes aparecem sujeitos da experiência do espaço, ou seja, sua culminância ocorre de acordo com um corpo social, historicamente determinado, que a realiza. Desde o momento em que os leitores se propõem a desvendar o que há de imaginário em Casa de Pensão, a sociologia da arte se autentica pelo caráter de representação de conhecimento ligado ao contexto carioca do século XIX.

A estrutura artística de Casa de Pensão pode ser vista pela via dupla, tanto pela linguagem intertextual, que influencia as escolhas lingüísticas e a construção de sentido do texto, da mesma forma que pode influenciar os leitores e uma sociedade 
pelo ponto de vista expresso nas entrelinhas do discurso literário. Quando Aluísio opta por inserir, gradativamente, o Naturalismo, respeitando o hábito que o público ainda cultivava pelos romances românticos, expressa a intenção de familiarizar o leitor com o novo gênero em plena atividade na Europa graças à produção artística de Émile Zola, que influencia a literatura brasileira, principalmente as produções de Aluísio Azevedo. A preocupação com a elaboração de uma obra literária representa um sistema dialógico integrado pelo leitor e escritor. Sobre o sistema de comunicação, o estruturalista Lootman destaca que:

\begin{abstract}
A escolha pelo escritor de um gênero, de um estilo ou de uma tendência artística determinados é também a escolha da linguagem na qual ele pensa falar ao leitor [...] A transcodificação de uma linguagem noutra, extremamente produtiva na maioria dos casos e que surge em ligação com os problemas interdisciplinares, descobre num único objeto, tal como parecia antes, os objetos de duas ciências ou leva à elaboração de um novo domínio do conhecimento e de uma nova metalinguagem que lhe é própria (LOTMAN, 1978, p. 50-51).
\end{abstract}

A leitura intratextual do romance Casa de Pensão pode identificar códigos ligados ao gênero da publicação. No entanto, apenas os leitores contemporâneos à publicação do romance-seriado, ou aqueles que têm acesso ao conjunto de quarenta seqüências e das notícias da Questão Capistrano poderão identificar facilmente os códigos extratextuais, que ajudam o leitor a entender a situação comunicativa do discurso ficcional. Quando Aluísio elaborou a nota Antes de principiar, utilizou uma linguagem individualizada para dialogar com os leitores da publicação seriada, enquanto na versão em livro, que atinge uma dimensão social mais ampla, a nota foi suprimida.

Como ocorre na interpretação, os diferentes processos de produção são estratégicos e variáveis. O fato de Aluísio utilizar informações de diferentes níveis e fontes pode estar vinculado ao processo de formulação efetiva de significados e modelos que o autor deseja transmitir para seus leitores (GARGUREVICH, 1982, p.155).

Duas publicações envolvem diferentes estâncias de leitura de mundo, porque nem mesmo os documentos que envolvem o processo de produção das duas versões de Casa de Pensão e os jornais da época desvendam todos os códigos extratextuais do romance ou sua dialogia externa. No entanto, por intermédio do texto artístico, a leitura de um microcosmo da sociedade carioca pode ser feita em 
diferentes épocas, a partir da compreensão intratextual, limitada ao que o formato em livro conseguiu absorver e cristalizar na linguagem literária.

\subsection{Jornalismo, literatura e o híbrido}

Gargurevich apresenta na obra Géneros periodísticos uma visão ampla sobre os gêneros jornalísticos, a partir dos cinco gêneros principais: nota informativa; entrevistas; crônicas; reportagens; gêneros gráficos; exemplificativos. Na seqüência, também são tratados outros gêneros, tais como: coluna, artigo, testemunho, resenha, crítica, polêmica, campanha, folhetim. Considerando a diversidade de gêneros jornalísticos e a proximidade que eles têm com a literatura, possíveis combinações podem caracterizar formas jornalístico-literárias. Se, por um lado, o estilo jornalístico se caracteriza, principalmente, pelo seu objetivo de transmitir informação e não necessariamente o prazer estético, que é o caso da literatura, por outro lado, o "Novo jornalismo" utiliza a informação com refinadas técnicas literárias, capazes de transformar uma "notícia" em obra de arte (GARGUREVICH, 1982, p. 12).

Ao aplicarmos as definições de Gargurevich (1982) ao contexto que envolveu o processo de produção de Casa de Pensão, a Questão Capistrano (1876) situa-se na esfera jornalística, como registro de um acontecimento que, por ter atingido grande repercussão, foi noticiado com proeminência por dois dos mais representativos periódicos cariocas da década de 70 do século XIX. Embora não saibamos como os jornalistas interpretaram a Questão Capistrano e os contextos que permearam as notícias, ou, ainda, como essas interpretações garantiram o sucesso do discurso informativo, a microanálise, à qual se dedica esta etapa da pesquisa, pode levantar hipóteses sobre o processo de produção textual dessas notícias, a partir do momento em que desvenda vozes que reaparecem em Casa de Pensão. No entanto, não temos a pretensão de reconstruir uma imagem da realidade, que poderia resultar em um panorama concreto ou deformado, por isso, os acontecimentos que envolveram a sociedade carioca em fins do século XIX, registrados em narrativas jornalísticas, representam pontos de vistas sobre um fato, 
por meio do qual se torna possível construir, de maneira representativa, o universo social daquele período e em diálogo com a diegese que lhe serviu de ensejo.

Como o livro reflete dimensões sociais e ideológicas da construção da notícia, o texto informativo configura-se como pano de fundo da ficção, enquanto o romanceseriado referencia diretamente o drama na nota que introduz as seqüências publicadas no jornal Folha Nova - RJ. Para entendermos esse processo, os procedimentos devem considerar os elos comuns entre as notícias e o desfecho do romance, além de outros aspectos pertinentes para o estudo do processo de criação utilizado por Aluísio Azevedo.

Ao aproximar literatura e jornalismo, Aluísio apresenta Casa de Pensão como um "momento do encontro dos meios, é um momento de liberdade e libertação do entorpecimento e do transe que eles impõem aos nossos sentidos" (MCLUHAN, 1964, p. 75). Desse modo, procuramos revelar que o hibridismo discursivo configurase como uma linguagem capaz de fundir gêneros estanques, o que nos possibilita lançar um novo olhar para o contexto do processo de criação de Casa de Pensão.

\subsection{Duas narrativas jornalísticas de um crime}

Esta pesquisa elege dois jornais de grande circulação para a análise das notícias sobre a Questão Capistrano, sendo: o Jornal do Comércio, um dos mais tradicionais periódicos cariocas e a Gazeta de Notícias, cuja fundação ocorreu um ano antes da ocorrência do assassinato de Capistrano. Apontamentos realizados por Sodré (1966, p. 127) revelam que, desde 1827, o Jornal do Comércio era o único jornal respeitável por sua já consolidada reputação de conservador, destacando-se, principalmente, pela ênfase dada aos assuntos políticos e à abrangência nacional e internacional das notícias. Sodré (1966, p. 257) também destaca que, em 1875, foi fundada a Gazeta de Notícias, causando impacto, naquele momento, pelo estilo "barato, popular, liberal, vendido a quarenta réis o exemplar". Considerando as especificidades ligadas ao perfil de cada jornal, pressupomos que os leitores dos dois periódicos poderiam compartilhar do posicionamento de cada um dos jornais. Por essas razões, apresentaremos uma cronologia dos acontecimentos relativos ao assassinato de Capistrano da Cunha, publicada pelo Jornal do Comércio e pela 
Gazeta de Notícias, ambos jornais cariocas, no mês de novembro de 1876. Além disso, o entendimento do modo como o conjunto de notícias foi transmitido permitenos construir grandes narrativas de um acontecimento, o que estabelece correspondência com a crônica e com o método utilizado por Aluísio, como leitor e escritor de narrativas do cotidiano; ao mesmo tempo, Casa de Pensão sintetiza aspectos da cultura brasileira do seu período:

Escrevendo com os olhos sobre a realidade, atento ao acontecimento imediato, Aluísio Azevedo não despreza - como nenhum outro romancista de sua época - a matéria ficcional que se oferece. É sobre essa matéria ficcional, resultante do complexo cultural brasileiro, que se debruça para erguer a melhor parte de sua obra novelística ${ }^{115}$.

Do mesmo modo que a nota que introduz o romance-seriado Casa de Pensão se dirige diretamente ao leitor, van Dijk (1990, p. 122) destaca que o discurso jornalístico, assim como qualquer outro texto informativo, possui uma relação com o contexto comunicativo. Desse modo, os leitores, enquanto participantes no processo de comunicação, fazem parte, mesmo que indiretamente, do discurso jornalístico. Assim como o Jornal do Comércio, a Gazeta de Notícias também não se dirige diretamente aos leitores com a menção a um "vós", mas ambos contam com um "ele", Capistrano, muitas vezes citado sem o sobrenome da Cunha, o que sugere certa popularidade do estudante, gerada pela repercussão do episódio. Apesar disso, a Gazeta de Notícias, no dia 20 de novembro, refere-se a "eles", "aos nossos leitores", para definir o direcionamento dado pelo jornal, ao mesmo tempo em que se configura como um diálogo com os receptores.

No contexto comunicativo, é em Capistrano que estão centralizadas as informações noticiosas, mesmo quando são descritas as manifestações da população que acompanhava o desfecho da trama que o vitimou. Também estão ligadas ao "ele" as vozes dos "eles", que se referem aos operadores do discurso, envolvidos no processo aberto por Alexandre Pereira, com a finalidade de restituir a dignidade de sua irmã, Júlia.

Como as notícias transmitidas pelos dois jornais que compõem o corpus deste estudo não são assinadas, torna-se difícil identificar a autoria das notícias que, segundo van Dijk, poderiam ser caracterizadas como "identificações secundárias de

${ }^{115}$ Adonias Filho (introdução ao Touro Negro, 1961, p. 3). 
uma voz institucional" (VAN DIJK, 1990, p. 113), apesar de o jornalista representar um ser social e o processo de produção de notícias não ser inseparável do contexto em que são produzidas.

Sobre a produção das notícias, van Dijk (1990, p. 256) destaca que "a reconstrução e a reprodução dos acontecimentos informativos no processo da escritura jornalística incluem tanto formas altamente complexas do processamento do texto como estratégias e representações cognitivas subjacentes a estes processos". Por outro lado, a compreensão da notícia está relacionada com os efeitos que o contato com o texto provocara sobre os leitores. Nessa perspectiva:

\begin{abstract}
As estruturas das informações jornalísticas condicionam em muitos níveis aos leitores para que desenvolvam esses marcos interpretativos e não os alternativos, que utilizam outros objetivos, normas, valores e ideologias para proporcionar contrainterpretações dos acontecimentos informativos (VAN DIJK, 1990, p. 259).
\end{abstract}

A partir dos pressupostos teóricos de van Dijk, realizamos uma leitura de como foram elaboradas as notícias sobre o julgamento e o assassinato de Capistrano da Cunha, a partir de exemplos representativos, com a finalidade de verificar de que maneira o discurso da notícia foi construído. Ressaltamos que, nesta pesquisa, a interpretação dos títulos e demais particularidades dos discursos jornalísticos transmitidos está diretamente relacionada aos conceitos de Genette (1995), os quais se referem à focalização e ao ponto de vista. De modo semelhante ao que ocorre com o romance Casa de Pensão, os jornais analisados, enquanto organizações institucionais de ampla circulação, possibilitam a abrangência dos desdobramentos de cada notícia, como forma de apresentar recortes de mundo, sob a perspectiva textual.

\title{
4.5.1 Jornal do Comércio
}

No dia 18 de novembro de 1876, o Jornal do Comércio apresenta uma notícia intitulada "Júri". Como o título sugere apenas que a informação ali registrada está relacionada a um julgamento, os leitores precisariam encontrar no texto detalhes sobre a temática anunciada. 
A notícia relacionada ao tema "Júri" apresenta um relato descritivo e rico em detalhes do julgamento de Capistrano. Nela, são apresentados todos os integrantes do conselho. De acordo com os relatos apresentados, depois da acusação alegar que Júlia Pereira sofreu agressões físicas e violência sexual, Capistrano defende-se dizendo que:

não praticara tais violências; que a contusão nos lábios que a ofendida apresentou fora devida a um soco que o irmão dela quis dar nele acusado, e que ela metendo-se de permeio recebeu em cheio. Disse que mais atribui o processo ao ódio que lhe vota a mãe da ofendida.

Como resultado das revelações feitas por Capistrano e a defesa apresentada pelos advogados o Sr. Dr. Busch Varella e os outros patronos do réu, os Srs. Dr. Duque-Estrada Teixeira e conselheiro Saldanha Marinho: "O conselho respondeu negativamente aos quesitos, e à idéia das respostas foi unanimemente absolvido". Quando saíram do tribunal, Capistrano e os seus advogados foram "saudados e acompanhados com vivas por grande parte do povo". Depois do julgamento, o juiz apelou da sentença.

Pressupomos que representantes do Jornal do Comércio entrevistaram pessoas que acompanharam essa audiência ou acompanharam esse momento, pois, de acordo com relatos presentes no mesmo jornal, ao meio-dia, fora necessário pausar a sessão, em conseqüência dos "sussurros produzidos pela grande afluência do povo que queria lugar no recinto do tribunal já de todo cheio".

No dia seguinte, ou seja, no dia 19 de novembro de 1876, o Jornal do Comércio registrava na $8^{a}$ coluna, o título "Processo Capistrano", cujo tema representa um resumo do texto da notícia, pois, de um dia para o outro, Capistrano deixou de ser anônimo. Busch Varella, um dos advogados do acusado, relata que, depois de retornar do tribunal do júri: "fui agradavelmente surpreendido pela esplendida manifestação com que imerecidamente me vitoriou a briosa mocidade acadêmica, que à frente de mais de duas mil pessoas se dirigiu à minha residência" (destaque nosso). Como resposta à gratidão manifestada pelos estudantes, o advogado registra que: "Debalde tentaria traduzir, em palavras a gratidão profunda de que me sinto penhorado, a linguagem convencional é pálida e frouxa para exprimir sentimento que irrompem espontâneos do íntimo da alma, 
limito-me a registrar no coração". Porém, essa publicação é um modo de apresentar um diálogo do advogado com a população que lhe demonstrou gratidão.

Se observarmos as características estruturais da notícia, a organização temática obedece a regras que consistem em chamar para o título um resumo da notícia e para o primeiro parágrafo, a síntese do texto, na medida em que apresenta as informações mais importantes, sob o ponto de vista do autor-jornalista (como voz do jornal); em seguida são relacionados os demais elementos, organizados cronologicamente. Para entendermos como foi apresentada a segunda notícia, citamos o relato datado de 20 de novembro de 1876, intitulado "assassinato", também importante porque os detalhes nele registrados contêm informações homólogas às do romance Casa de Pensão, ao mesmo tempo em que retoma a primeira notícia dada sobre o inquérito de Capistrano da Cunha.

Este parágrafo resume a notícia a ser apresentada, ao mesmo tempo em que situa os leitores que estão tendo o primeiro contato com a Questão Capistrano: "Teve ontem lúgubre desfecho um drama começado no recesso da vida íntima e que ultimamente foi trazido a público perante o tribunal do júri”.

As variações de ponto de vista, que de informativo passa a inserir marcas do gênero narrativo, comuns à linguagem literária, podem sugerir a mudança de focalização. Jogando com o duplo sentido da palavra modo, Genette (1995) apresenta a noção de modo dominante para caracterizar as alterações detectadas de maneira significativa no decorrer do discurso, que passa a apresentar mais informações que nos primeiros dias, compreendendo o conjunto de notícias.

Apresentando características composicionais de um texto ficcional, a narrativa descrita no segundo dia do desenrolar do drama apresenta espaço, tempo, personagens, clímax e desfecho. Nos dois últimos parágrafos, podemos detectar o ponto de vista moralizador impresso pelo Jornal do Comércio, como desfecho de um episódio, que alerta para os perigos existentes por trás de uma vida desregrada e inconseqüente:

Não poderemos terminar tão dolorosa narração sem lamentar esses dois malfadados moços, que, colegas, vivendo na mesma academia, em vez de amigos, se tornaram irreconciliáveis inimigos. As reflexões tristes que acaso desperta seriam talvez mal exibidas nesta ocasião.

Sirva, ao menos, este tremendo exemplo pra conter alguma vez os intentos da mocidade que, generosa, mas exaltada, não mede, nem o pode fazer sempre, porque tudo nessa quadra da vida é espontâneo, o alcance de seus atos (JC, 20 nov. 1876, destaque nosso). 
Em 21 novembro, o Jornal do Comércio lança o título "ASSASSINATO CAPISTRANO" (em caixa alta), seguido de 100 linhas organizadas cronologicamente. Essa notícia expõe os efeitos que esse caso provocou naqueles que acompanharam o desenrolar do drama, descritos a partir da comoção causada pelo velório de Capistrano, sem deixar de informar o andamento da investigação sobre o crime.

Nesse mesmo dia, o Jornal do Comércio relata que: "Ontem, logo depois do meio dia, algumas ruas das mais centrais, e com especialidade a da Quitanda [onde Capistrano foi assassinado], $\left(. .{ }^{116}\right)$ de povo". Se no início a multidão, possivelmente formada por curiosos, movia-se lentamente, "foi depois formado, pouco a pouco, compactos grupos". Na seqüência, acrescentam-se estas informações, que se confundem com um texto literário, pela linguagem empregada: "Esperavam todos o anunciado sabimento (sic), e, como era natural, e comentava-se à meia voz a tão lamentável ocorrência da véspera, triste desfecho de um drama íntimo". A linguagem alegórica e antitética descreve o impacto que essa morte causou sobre o destino de dois jovens: "para quem o futuro tanto deveria sorrir, arremessou um no túmulo e o outro no cárcere".

Com o passar das horas, e na medida em que se espalhava a notícia desse homicídio, a população se aglomerava em torno do falecido, então: "era quase impossível o trânsito pela rua da Quitanda".

Os mesmos advogados que defenderam Capistrano no tribunal, também ajudaram a carregar seu caixão: "Carregaram a princípio o caixão os Srs. conselheiro Saldanha Marinho, Drs. Duque-Estrada Teixeira, Busch Varela, Pinto Júnior e os Srs. Matos Cruz e Nunes de Sá"; e, depois, os estudantes e amigos do finado, "que assim foram a pé e de chapéu na mão até o largo de Valdetaro".

Considerando a notícia divulgada no dia 21 de novembro, não podemos afirmar se "contagia-se o coração de quantos viram o fúnebre cortejo, e não poucos olhos se umedeceram de lágrimas", ou se está contagiado o coração daquele que descreveu esse momento emocionante. Nossa hipótese fundamenta-se neste excerto, que estabelece continuidade com o anterior:

Era na verdade uma cena bem comovente aquele féretro, rodeado de mancebos, que, trajados de preto e com a tristeza estampada no rosto iam levar à última morada o companheiro de todos os dias, tanto nas árduas lidas do estudo, como nos descuidosos prazeres da mocidade.

${ }^{116}$ Ilegível. 
Essa linguagem antitética une dois extremos pelo pesar: de um lado, estava a lembrança dos dias felizes que a juventude, o companheirismo e a riqueza haviam proporcionado a Capistrano e, do outro, a posição trajada de preto acompanhava os últimos momentos fúnebres, que logo os separariam para sempre.

Quando o cortejo atingiu o "largo do Valdetaro foi o caixão posto em um carro, que seguiu a passo até o cemitério de $S$. João Batista, aonde chegou até as "5 1,4 horas"117, sempre acompanhados pelo mesmo crescido número de estudantes e amigos do finado".

À medida que chegavam à porta do cemitério "o conselheiro Saldanha Marinho e uma comissão de estudantes pegaram de novo nas argolas do caixão e carregaram-no até a sepultura, a cuja beira os Drs. Duque-Estrada Teixeira e Ferreira de Menezes pronunciaram algumas palavras repassadas de saudade". A comoção envolvia todos os que participaram do velório e, possivelmente, também motivou o autor deste relato a utilizar uma linguagem revestida de metáforas, para descrever aqueles que estavam: "Pagando assim o último tributo de amizade ao desditoso colega, que a mão da fatalidade acabava de lazer tombar o túmulo tão inesperadamente antecipando-se à da terrível enfermidade que o tinha de roubar talvez em bem pouco tempo", como se a fatalidade estivesse, de alguma forma, ligada à vida de Capistrano.

A partir desse ponto, há um gancho que estabelece conexão com as notícias apresentadas no dia anterior, como se fosse um segundo tema dentro do primeiro, que noticiou o velório de Capistrano: "Em aditamento às notícias que demos ontem, temos agora o depoimento de mais duas testemunhas e o resultado do exame feito no cadáver pelos médicos da polícia”. Depois o jornal (JC, 21 nov. 1876) transcreve o depoimento de Manuel José Pinto, caixeiro da casa de molhados n. 128, da rua da Quitanda, em que Capistrano tentou refugiar-se quando foi ferido pelo primeiro tiro, e quem declarou ter visto Alexandre Pereira com um revólver: "Capistrano deu então um grito, pedindo socorro, e, correndo, entrou no mencionado armazém, onde o acusado deu-Ihe mais dois tiros". Posteriormente, são apresentados os outros depoentes e o resultado da autópsia que, além de esclarecer que "a causa imediata da morte fora um ferimento penetrante do coração, pulmão esquerdo e hemorragia consecutiva, sendo encontrada uma bala cônica de revolver na cavidade do

${ }^{117}$ Possivelmente seja 5h15. 
pericárdio", também foi constatado que o "pulmão direito de Capistrano achava-se atrofiado e com tubérculos milhares".

Para entendermos a proximidade dos jornalistas com a tragédia noticiada, destacamos que o Jornal do Comércio, publicado no dia 22 de novembro de 1876, registra que dentre as pessoas que assistiram à necropsia de Capistrano estavam: "[...] os Drs. Carlos Frederico, S. G. ${ }^{118 ", ~ o ~ f u n d a d o r ~ e ~ r e d a t o r ~ d a ~ G a z e t a ~ d e ~ N o t i ́ c i a s ~}$ "Ferreira de Araújo e alguns estudantes de medicina".

Depois do triste desfecho, o Jornal do Comércio traz estas informações adicionais:

- Os alunos da Escola Politécnica resolveram tomar luto por sete dias pelo infeliz e desastroso fim do seu colega. O Sr. Visconde do Rio Branco, diretor da mesma escola, acompanhando-os no pesar, mandou que os trabalhos escolares fossem suspensos durante dois dias (JC, 22 nov. 1876).

\subsubsection{Gazeta de Notícias}

Em 20 de novembro de 1876, a Gazeta de Notícias anuncia "O ACONTECIMENTO DO DIA", em 123 dramáticas linhas.

Quando o primeiro parágrafo apresenta um resumo da Questão Capistrano, a gazeta deixa transparecer que, desde o primeiro momento, as informações direcionavam-se para a construção de uma narrativa do drama, empregando, para isso, linguagem poética, repleta de alegorias e metáforas, e que, possivelmente, poderia ser confundida com um trecho retirado de um romance, seguindo a tendência fixada pelo Jornal do Comércio. Nesse sentido, aquele periódico destaca que: "A população da nossa cidade foi ontem sobressaltada por um triste acontecimento, terrível desenlace de um drama, que há pouco todos presenciamos e que além de duas famílias, veio encher de luto a mocidade acadêmica, roubando-lhe um de seus membros" (GN, 20 nov. 1876).

O parágrafo seguinte também enfatiza a idéia de totalidade, para caracterizar a abrangência que esse drama teve em meio à população carioca, no ano de 1876: "Está ainda na memória de todos o processo Capistrano, causa primeira do terrível caso que vamos narrar aos nossos leitores". Como muitos leitores acompanharam o drama e o ponto de vista do jornal não conseguiria abranger todas as

${ }^{118}$ Somente foi possível ler as iniciais do nome. 
particularidades, o autor desse texto justifica a eventual omissão de algum detalhe importante, pois o texto foi escrito "conforme as informações que nos foi possível obter".

Nos parágrafos seguintes, são apresentadas informações muito parecidas daquelas noticiadas pelo Jornal do Comércio do mesmo dia. Vejamos a marca temporal no exemplo a seguir.

Jornal do Comércio:

Às dez horas da manhã, na rua da Quitanda, o estudante da Escola Politécnica João Capistrano da Cunha, que há três dias o júri absolveu da acusação de ter violentado D. Júlia foi assassinado com dois tiros de revolver por Alexandre Pereira, irmão de D. Júlia (JC, 20 nov. 1876).

Gazeta de Notícias:

Ontem, cerca de 10 horas da manhã, encontraram-se na rua da Quitanda Antônio Alexandre Pereira e João Capistrano da Cunha. O que se passou entre eles, ou se mesmo se chegaram a falar, não o podemos afirmar, porque nada nos consta a tal respeito (GN, 20 nov. 1876).

Na seqüência, o modo como as informações são apresentadas revela o estilo da Gazeta de Notícias (20 nov. 1876), como se houvesse um tratamento da linguagem sob a perspectiva de um escritor que domina tanto a linguagem literária e seus elementos constitutivos, quanto os níveis descritivos da notícia:

O que é porém infelizmente certo é que Alexandre Pereira, desfechou alguns tiros de revolver sobre Capistrano, o qual entrou agitado e precipitadamente pelo armazém no. 128 da rua da Quitanda, indo refugiarse em um pequeno compartimento que ali existe, tendo sempre perseguido por Alexandre que ainda da porta do pequeno gabinete disparou dois tiros sobre ele, saindo em seguida do armazém e indo colocar-se no passeio do lado oposto do estabelecimento, carregando de novo a arma que tinha em seu poder.

Capistrano, ferido mortalmente, chegou cambaleando à porta do armazém e caiu. A esse tempo já Alexandre Pereira havia sido preso por César Augusto de Abreu Mascarenhas, que segurando-o pelas costas, pediu a Antonio Pereira Barbedo, dono do armazém que lhe tirasse o revolver, o que obteve facilmente, visto Alexandre Pereira não oferecer a maior resistência [...].

Nesse momento, há uma interrupção no relato do homicídio para o comentário do autor dessa notícia, como se entrasse em cena a voz do narrador, 
elaborada nos seguintes termos: "Esse acontecimento, como era natural, atraiu extraordinária concorrência, a qual não se demorava em fazer os mais extraordinários comentários". Posteriormente, é dada continuidade à apresentação dos eventos que envolveram a morte de Capistrano da Cunha.

O Jornal do Comércio cita que Alexandre Pereira utilizou um revólver para matar Capistrano e a Gazeta de Notícias descreve que o revólver utilizado pelo "preso era novo, com a marca P. Lavanit, de seis tiros e conservava ainda uma carga, tendo três cápsulas de tiros disparadas. Foram também encontradas em poder dele dezessete cargas iguais a do revolver". Essa menção à arma de fogo estabelece uma aproximação com o romance-seriado Casa de Pensão, uma vez que o personagem Coqueiro recebeu uma "pistolinha" de presente na infância; e a vertente em livro descreve que Amâncio teve uma morte semelhante à de Capistrano.

Ao ser interrogado pelo Sr. Dr. Torquato Couto, o acusado respondeu o seguinte: "Chama-se Antônio Alexandre Pereira, filho de Alexandre Pereira, já falecido e de Júlia Clara Pereira, ter 23 anos de idade, ser solteiro, estudante da escola Politécnica, natural da Bahia e morador na travessa do Meirelles n. 2, em Santa Tereza".

Sem subterfúgios, Alexandre:

Declarou que foi ele quem desfechou os tiros sobre João Capistrano da Cunha, não se recordando de quantos tiros disparou em desafronta da honra de sua família que foi ofendida por Capistrano na pessoa de sua irmã, e que, se bem se recorda, praticou o ato de que é acusado, na rua da Quitanda, e que no estado de agitação em que se acha não pode mais responder a coisa alguma (GN, 20 nov. 1876).

Depois de acrescentar mais alguns detalhes sobre o futuro julgamento do acusado, esse parágrafo encerra a notícia desse dia 20: "São estas, por enquanto, as informações que temos acerca de tão lamentável acontecimento, a respeito do qual iremos informando os nossos leitores". 
As notícias do dia 21 de novembro de 1876 estabelecem continuidade ao relato da Questão Capistrano, com a inserção de seu desdobramento: "Ontem à tarde foi levado à sua última morada, no cemitério de $\mathrm{S}$. João Batista, o cadáver do estudante João Capistrano da Cunha, vítima de lamentável desgraça que já noticiamos e que consternou toda cidade".

Nos dois jornais não há menção à família de Capistrano, talvez porque naquela época era impossível sair de Campo Largo - PR e chegar ao Rio de Janeiro - RJ em um dia. Por esse motivo, os amigos e advogados do estudante eram as pessoas mais próximas e foram eles os que mais demonstravam padecer com a perda. Carregaram o "caixão à mão, pegando nas argolas os Sr. conselheiro Saldanha Marinho, Drs. Bush Varela, Duque Estrada Teixeira, Pinto Júnior, Macedo B (...) (juiz de direito em Campo Largo, onde residia o finado) e o Sr. Mattos Cruz". As ruas na cidade do Rio de Janeiro são destacadas - começando por aquela onde o estudante foi abordado por Pereira e seguindo por outras localizadas no centro da cidade: "ruas da Quitanda, Ouvidor, Largo São Francisco, rua do Teatro, Rocio, Visconde do Rio Branco, Lavradio, Arcos, Mangueiras, Lapa, Catete, Botafogo". Quando o cortejo chegou ao cemitério, sobre o caixão seus colegas e amigos colocaram "duas coroas de saudades, em cujas fitas se lia - Eterna saudade - do nosso colega - e uma senhora, da rua da Quitanda [talvez vizinha do local onde Capistrano foi baleado], colocou também sobre o caixão uma coroa de saudades naturais".

O momento mais comovente do funeral ocorreu quando, junto à sepultura, "o Sr. conselheiro Saldanha Marinho duas vezes tentou falar, mas a emoção embriagava-Ihe a voz". Unida a esse momento, uma parcela da população carioca comparecia de modo massivo ao espetáculo propiciado pelo desfecho dramático da Questão Capistrano:

Por todas as ruas aglomerava-se o povo para ver passar o fúnebre cortejo, composto de cerca de 2000 pessoas ${ }^{119}$ de diversas classes da sociedade, destacando-se entre todas a mocidade acadêmica, mais que finalizada pelo triste fim de seu companheiro de estudos (GN, 20 nov. 1876).

No mesmo jornal, duas colunas depois da notícia acima, podiam ser lidas as seguintes informações: "Ontem à tarde distribuiu-se um folheto com o título - $A$

\footnotetext{
${ }^{119}$ Mesmo número estimado pelo Jornal do Comércio do dia posterior ao crime.
} 
honra das famílias -, que se ocupa com o desastroso acontecimento que enlutou esta cidade - a morte do estudante Capistrano". Esse dado revela que, mais do que noticiar um drama, a Gazeta de Notícias também elaborou um folheto destinado às famílias envolvidas direta ou indiretamente com esse episódio dramático e aos leitores que teriam acesso a esse texto pelo jornal.

\subsubsection{Construção do ponto de vista}

Ao fixar "marcos interpretativos", o jornal é capaz de guiar o leitor à recepção do texto, graças ao horizonte criado por intermédio do discurso jornalístico. No entanto, como a retórica do estilo jornalístico está relacionada ao modo como cada jornal informa o público sobre o desenrolar da Questão Capistrano, o prolongamento desse episódio e a comoção causada por seu desfecho também podem ter provocado mudança de perspectiva por parte dos jornalistas. Considerando isso, destacamos os apontamentos de Genette (1995, p. 163), ao dizer que: "A narrativa de acontecimentos, porém, qualquer que seja o seu modo, é sempre narrativa, isto é, não-verbal em verbal: a sua mimese nunca será mais que uma ilusão de mimese, como toda a ilusão dependendo de uma relação eminentemente variável entre o emissor e o receptor".

Quando Gargurevich (1982, p. 11) apresenta especificidades sobre os gêneros que se ligam à notícia, o autor evidencia que os gêneros jornalísticos são "formas que buscam o jornalista para expressar-se, devendo fazê-lo de modo diferente, segundo a circunstância da notícia, seu interesse e, sobretudo, o objetivo de sua publicação".

Seguindo a linha de raciocínio estabelecida a partir da leitura dos conceitos citados de Genette (1995) e Gargurevich (1982), podemos dizer que, em um primeiro momento, o Jornal do Comércio apresentou as notícias como se estivesse apenas transcrevendo o que foi visto ou relatado. Em um segundo momento, ocorre mudança de ponto de vista, aprimoramento estrutural e de linguagem, como se o próprio jornalista, ao acompanhar o sobressalto que a morte do estudante causou sobre a população carioca do período, compartilhasse a dor assistida. A Gazeta de Notícias, por outro lado, assumiu o posicionamento de porta-voz das dores dos 
leitores, desde o primeiro dia em que foi lançada a primeira notícia, como se estivesse apresentando uma narrativa da informação.

Em momentos e proporções diferentes, ambos os jornais utilizam linguagem plástica, retórica característica do texto poético, que transforma a notícia em história de um acontecimento e se delineia na medida em que esse tema adquire proporções significativas e culmina com o assassinato do estudante da Escola Politécnica.

\subsection{A nota Antes de principiar e o encontro de dois gêneros}

Em 1883, o escritor Aluísio Azevedo anuncia seu novo romance Casa de Pensão, que passaria a ser publicado no jornal Folha Nova, a partir do início de março daquele ano. Como a finalidade do escritor era explicitar o que havia de ruim no cotidiano das casas de pensão, apresentou aos leitores contemporâneos à publicação do romance-seriado a nota Antes de principiar $(A P)$, vista como uma apresentação sumária da diegese. Esse paratexto delineia: tema, ponto de vista, espaço, gênero e objetivo.

No tempo histórico da narrativa, o autor tinha consciência de que muitos leitores ainda estavam habitados à leitura de romances românticos. No entanto, motivado pela visão naturalista, Azevedo ressalta que pretendia: "[...] rasgar aos olhos do leitor a parede de uma dessas velhas casas de pensionistas e expor sua nudez fria e profundamente comovedora os dramas secretos que ali dentro se consomem, terríveis e obscuros, como a luta dos monstros no fundo do oceano".

Se, por um lado, o autor diz querer revelar o que vira ou ouvira, a fim de que o leitor pudesse conceber sua narrativa como descrição de uma realidade, na qual arte e natureza se fundem em nome de uma verdade e se tornam literatura, por outro lado, usa a metáfora "rasgar os olhos" que se assemelha ao ato de abrir as cortinas de um palco. Além disso, impulsionado pelo desejo de verdade, o autor descreve uma fábula que sugere fantasias e imaginações românticas, mediadas pelos princípios básicos do maniqueísmo. Jean-Yves Mérian (1988), estudioso da obra de Aluísio Azevedo, defende a tese de que: 
[...] o caráter híbrido que ressaltamos a propósito dos folhetins no plano estético, encontra-se também no plano das intenções do autor. Seus folhetins não são romances de tese, mas o autor desenvolve neles teses sociais e políticas claras ao mesmo tempo em que, por outro lado, faz descrições de cenas irreais e fantásticas (MÉRIAN, 1988, p. 494).

Aluísio se propõe a revelar "toda a hediondez dessa existência artificial e hipócrita que corrompe nossa sociedade, como uma moléstia secreta e inconfessável corrompe o organismo humano". Portanto, pautado no posicionamento naturalista de apresentar a sociedade como uma organização adoecida, o escritor destaca: "Desejo patentear ao leitor todo o mal, todo o desmantelamento, todo o desequilíbrio e toda a miséria”.

Então, perguntamos-nos se o crime cometido por Alexandre Pereira e o comportamento da mãe e da irmã são referenciais explicativos do "que podem resultar a uma família, sempre que ela comete a imprudência de introduzir no seio pessoas", como Capistrano da Cunha, "que não são solidárias de sua dignidade, que não são responsáveis pela sua honra, que não se acham ligadas, nem pelo parentesco, nem pelo amor, nem pelo respeito". Por isso, seduzir a filha da proprietária assumiria o aspecto de aventura, e que, por conseguinte, os hóspedes "nunca poderão compreender essa religião do lar, que nos conduz a todos os heroísmos, essa vigilância carinhosa e venerada com que cercamos os entes fracos confiados a nossa guarda". Essa visão positivista evoca o leitor a zelar da instituição sagrada chamada família contra possíveis pensionistas oportunistas.

Para Lewis (apud MCLUHAN, 1964, p. 85), o ponto de vista privilegiado mostra que "o artista está sempre empenhado em escrever a minuciosa história do futuro, porque ele é a única pessoa consciente da natureza presente!". Em Casa de Pensão ele evoca os leitores à análise da realidade, como se buscasse acordá-los do entorpecimento provocado pela ingenuidade de não se refletir sobre as relações efêmeras e o perigo de inserir um estranho no convívio familiar.

Embora não esteja explícita a referência à família Pereira, os sete anos que separam a Questão Capistrano da publicação do romance-seriado Casa de Pensão são um período curto, o que possibilitava o encontro de ficção e história. Júlia, por exemplo, poderia ler, aos trinta anos, o drama vivido aos vinte e três, quando se envolveu com Capistrano. Ao ler algumas das seqüências folhetinescas, poderia se imaginar como referência da personagem Amélia. E, dessa forma, muitos outros leitores poderiam reconhecer alguma familiaridade nas representações. 
Prevendo essas possibilidades e esses efeitos, o autor exime-se, antecipadamente, na parte final da nota introdutória, com o seguinte apelo:

\begin{abstract}
Agora resta-me apenas pedir ao leitor que, se por ventura se reconhecer em alguns dos tipos, ou se descobrir em alguns dos meus folhetins qualquer cena de sua vida, queira de antemão perdoar-me semelhante coisa, porque em tal fato não haverá intenção de ofensa ou maldade, porque os males reais só podem ser combatidos pela própria realidade $(A P)$.
\end{abstract}

A esse respeito, inserimos a constatação realizada por Lúcia Miguel Pereira (1975, p. 126-127 apud SODRÉ, 1992, p. 216) de que Casa de Pensão é um livro "cujos métodos constatam, um pouco paradoxalmente, com as simetrias, os métodos rígidos, os esquemas estabelecidos e rigorosos de sua construção. Surge dele algo que tem vida própria e que ganha os nítidos contornos da realidade".

Por ter sido direcionada para uma "sociedade de leitores" específica, pertencente ao contexto produtivo da obra, a nota foi suprimida na versão em livro. Essa estratégia instaura o duplo horizonte: o primeiro caracteriza-se como interno ou literário, implicado pelos efeitos que a obra produz em seus leitores, receptores, enquanto o segundo é o "mundivivencional" (ISER, 1979, p. 50), ou seja, um universo restrito ao leitor-testemunho da Questão Capistrano, inserida nas entrelinhas do pano de fundo de Casa de Pensão. Portanto, leitor da nota: "É em torno dessa verdadeira calamidade que se propõe girar o meu novo livro. Ele pretende bater o mal e encher o abismo da Casa de Pensão com algumas cem páginas de oitavo francês". Mesmo sabendo que: "Talvez seja até irrisório tentar entupir um abismo com papel, mas em todo o caso a intenção é legítima”. Portanto, a visão naturalista de Aluísio Ihe fazia crer que "os males reais", testemunhados ou lidos em relatos jornalísticos "só podem ser combatidos com a própria realidade", ou seja, buscando em acontecimentos o material para compor seu novo romanceseriado.

Hans Robert Jauss ${ }^{120}$ destaca a dimensão comunicativa da obra literária ao reinterpretar a noção de fusão de horizontes de Gadamer ${ }^{121}$. Segundo Jauss, cada participante do ato comunicativo da literatura, o escritor e seu público histórico, possui um horizonte existencial em que repousam valores, regras sociais e

\footnotetext{
${ }^{120}$ Cf. JAUSS, Hans Robert (1994).

${ }^{121}$ Horizonte de expectativa é um conceito originário de Husserl, foi posteriormente reelaborado por Gadamer, e refere-se ao sistema de referências forjadas pelas tradições culturais anteriores.
} 
artísticas. O escritor, no papel de criador, produz sua obra, admitindo ou opondo-se ao seu horizonte existencial.

Em Casa de Pensão, o pano de fundo reproduz um drama que fora anunciado no "Jornal do Comércio" e na "Gazeta de Notícias", no ano de 1876, ano em que Aluísio Azevedo chegou ao Rio de Janeiro, e apenas sete anos antes da apresentação do romance-seriado. Nesse pequeno intervalo de tempo, ainda era possível conservar a lembrança dos detalhes do drama. Segundo Gadamer (1997), leitores contemporâneos à obra e leitores de diferentes épocas apresentam diferentes horizontes que, em contato com o texto, interagem com o conjunto de valores proposto e a consciência histórica dos receptores. Na medida em que o discurso suscita posições contrárias às dos leitores, a obra artística conseguirá questioná-los e agirá sobre a sociedade e a história.

Nos exemplos abaixo, apresentamos fragmentos de três documentos: os dois primeiros têm como fonte o Jornal do Comércio e a Gazeta de Notícias, com registros da Questão Capistrano; o terceiro corresponde ao romance Casa de Pensão ${ }^{122}$, em formato de livro, com recortes de notícias sobre o julgamento e assassinato de Amâncio. Esse corpus está ligado pela dialogia discursiva, evidenciada pela apresentação dos motivos que levaram Capistrano e Amâncio ao tribunal, bem como o impacto que suas mortes causaram sobre os que se compadeceram de suas dores. Além de aproximar as vozes dos dois estudantes, fazendo uma comparação entre Amâncio e seu modelo, ilustramos a presença do discurso híbrido em Casa de Pensão, manifestado na semelhança entre as duas linguagens, a jornalística e a literária. Ressaltamos, ainda, que, como o desfecho da história foi apresentado apenas na vertente em livro, o diálogo intertextual não contempla o romance-seriado.

\footnotetext{
${ }^{122}$ Embora tenhamos como ponto de referência o romance-seriado, estes exemplos foram extraídos da parte final do livro, porque a variante publicada no jornal Folha Nova contempla apenas doze dos vinte e dois capítulos que integram o livro.
} 


\section{Quadro 01 - Fragmentos dos dois julgamentos e os assassinatos de Capistrano e Amâncio}

\begin{abstract}
Os estudantes formigavam assanhados como se acabassem de ganhar uma vitória. O nome do [...] era repetido com transporte; um grupo enorme de rapazes [...] aguardava o colega à saída do júri, para o conduzir em triunfo ao Hotel Paris, onde havia à sua espera um almoço e a banda de músicos alemães.
\end{abstract}

Disse [...] no tribunal que não praticara tais violências; que a contusão nos lábios que a ofendida apresentou fora devida a um soco que o irmão dela quis dar nele acusado, e que ela metendo-se de permeio recebeu em cheio.

Já ninguém se entendia com o estardalhaço das vozes, da música e dos foguetes. [...] carregado em triunfo nos ombros dos colegas, entrou no hotel ao som do grande hino, chorando de emoção e agitando freneticamente o seu velho chapéu de feltro, desabado e boêmio.

Ao meio dia suspendeu o presidente do tribunal a sessão em conseqüência sussurros produzidos pela grande afluência do povo que queria lugar no recinto do tribunal já de todo cheio.

A população da nossa cidade foi ontem sobressaltada por um triste acontecimento, terrível desenlace de um drama, que há pouco todos presenciamos e que além de duas famílias, veio encher de luto a mocidade acadêmica, roubando-lhe um de seus membros.

Esperavam todos o anunciado sabimento, e, como era natural, e comentava-se à meia voz a tão lamentável ocorrência da véspera, triste desfecho de um drama íntimo, que marcaria para sempre dois moços, para quem o futuro tanto deveria sorrir, arremessou um no túmulo e o outro no cárcere.

A cidade inteira abalou-se, demoveu-se, para deixar passar aquela estranha procissão de um magro cadáver de vinte anos.

Era na verdade uma cena bem comovente aquele féretro, rodeado de mancebos, que, trajados de preto e com a tristeza estampada no rosto iam levar à última morada o companheiro de todos os dias, tanto nas árduas lidas do estudo, como nos descuidosos da mocidade.

Pagando assim o último tributo de amizade ao desditoso colega, que a mão da fatalidade acabava de lazer tombar o túmulo tão inesperadamente antecipandose à da terrível enfermidade que o tinha de roubar talvez em bem pouco tempo.

O funeral atingiu dimensões gigantescas; parecia que se tratava da morte de um grande benemérito da Pátria.

O caixão foi carregado a pulso, coberto de coroas; no cemitério ninguém se podia mexer com a multidão que afluía. Um delírio!

Sobre o caixão [...] deposto seus colegas e amigos duas coroas de saudades, em cujas fitas se lia - Eterna saudade - do nosso colega - e uma senhora, da rua da Quitanda, colocou também sobre o caixão uma coroa de saudades naturais.
$\mathrm{CP}, \mathrm{p}$ 189

J.C

$21 / 11$

$\mathrm{CP}, \mathrm{p}$. 189

$\mathrm{CP}, \mathrm{p}$. 190

$\mathrm{CP}$, 1977,

p. 181

J.C

18/11, 1876

$\mathrm{CP}, \mathrm{p}$. 182- 
Nos exemplos acima, o livro caracteriza-se como agente produtor de conhecimento, na medida em que Casa de Pensão descreve acontecimentos, mas não é produtor de consciência, por isso o livro apenas estabelece índices relacionais com a Questão Capistrano. Segundo Mcluhan (1964, p. 68), de todas as grandes uniões híbridas que geram furiosa liberação de energia e mudança, nenhuma supera o encontro entre as culturas letradas e as culturas orais.

Quando confrontamos os textos informativos da Questão Capistrano e o desenrolar da diegese com o assassinato de Amâncio, podemos evidenciar que este último apresenta marcas do gênero e estilo que são próprios do texto jornalístico, pela presença de textos condensados de informações. No entanto, não podemos deixar de citar o grau de proximidade entre as duas linguagens, na medida em que esses registros jornalísticos apresentam alegorias e metáforas, caracterização de personagens, espaço, tempo, com elementos constitutivos do texto ficcional.

Se por um lado o registro jornalístico, que imprimiu os efeitos e a comoção que a morte de Capistrano provocou sobre a comunidade acadêmica da Escola Politécnica, descreve que os colegas estavam: "Pagando assim o último tributo de amizade ao desditoso colega, que a mão da fatalidade acabava de fazer tombar o túmulo tão inesperadamente [...]”. (JC, 21 nov. 1876). Por outro lado, o livro destaca que, após a morte de Amâncio: "A cidade inteira abalou-se, demoveu-se, para deixar passar aquela estranha procissão de um magro cadáver de vinte anos"123. A morte do protagonista - que poderia ter sido o herói de Casa de Pensão, se os vícios não o tivessem arrastado para a devassidão -, é característica do romance Naturalista; o que mais interessa é o caráter banal da existência comum. Segundo as leis externas, todos são determinados e regidos pelo meio, no ciclo vida-morte.

Em continuidade ao conteúdo do livro, o enterro do maranhense é apresentado como uma verdadeira apoteose: "o caixão foi carregado a pulso, coberto de coroas; no cemitério ninguém se podia mexer com a multidão que afluía. Um delírio!”.

O diálogo entre as linguagens literária e jornalística apresenta indícios de que o texto noticioso encorpou tipologias características do texto literário, e a diegese de Casa de Pensão, por sua vez, preservou traços da técnica jornalística. Essa simbiose se liga pelo eixo temático, que pode perpassar vários gêneros, e pela

${ }^{123}$ CP, 1977, p. 189-190. 
linguagem híbrida, oriunda de influências recebidas dos meios jornalístico e literário, como crônicas do cotidiano.

A relação intertextual utilizada por Aluísio configura-se como um procedimento capaz de reativar estruturas relacionais. As vozes discursivas de Casa de Pensão estabelecem unidades de sentido para aqueles que acompanharam, direta ou indiretamente a morte de Capistrano. Para confirmar as dimensões e os efeitos desse acontecimento, Menezes (1958, p. 147) ressalta que: "[...] o carioca da época não fala de outra coisa, não discute outro assunto, não se preocupa senão com os dois processos criminais, apesar de rotineiros, em que se misturam a honra de uma moça e o homicídio do seu sedutor".

Menezes (1958, p. 329-332), biógrafo de Aluísio Azevedo, acrescenta que Aluísio chegou ao Rio de Janeiro em 1876, aos 19 anos de idade, e pôde acompanhar, nos principais jornais cariocas, o desdobramento do drama, popularmente conhecido por Questão Capistrano. O fato de ter testemunhado esse episódio Ihe permitia utilizar informações ainda vivas em sua memória para a composição de um romance. Reconhecido em seu meio pela polêmica suscitada em suas produções, Aluísio encontrou nas notícias a matéria criativa, compartilhando o método utilizado por jornalistas e repórteres, como uma forma de acompanhar o desenvolvimento midiático.

Assim como o discurso apresentado pelos jornais de grande circulação na década de 70 do século XIX, Aluísio, escritor-jornalista, desenvolveu seu estilo ímpar, rico de alegorias e representações imagéticas, a partir de sua visão de mundo e em defesa de suas crenças. Nessa perspectiva, o jornalismo é algo muito mais que a técnica, as fórmulas, o trabalho e a habilidade (VIVALDI, 1979).

\subsection{Aventura, intriga e morte: das páginas policiais à Casa de Pensão}

A Questão Capistrano tem início em 1876, quando o paranaense Capistrano da Cunha prefere não ceder às pressões de Alexandre, por isso tenta fugir do Rio de Janeiro e do casamento com Júlia. Não encontrando outra saída, Alexandre presta queixa contra Capistrano, que por sua vez contrata três advogados para a sua defesa. Para esquivar-se da acusação, diz ao tribunal que não praticara nenhum tipo 
de violência contra Júlia, esclarecendo "que a contusão nos lábios que a ofendida apresentou fora devida a um soco que o irmão dela quis dar nele acusado, e que ela metendo-se de permeio recebeu em cheio" (JC, 18 nov. 1876).

Nessa época, os jornais favoreceram a divulgação do julgamento, e a dimensão desse assunto era tão grande, que se formaram partidos no tribunal: o público não conseguia conter a emoção, então se formava certo alvoroço. "Ao meio dia suspendeu o presidente do tribunal a sessão em conseqüência dos sussurros produzidos pela grande afluência do povo que queria lugar no recinto do tribunal já de todo cheio" (JC, 18 nov. 1876). Na versão em livro, esse episódio é transcrito da seguinte forma: "já ninguém se entendia com o estardalhaço das vozes, da música e dos foguetes", principalmente quando tudo levava a crer que Amâncio seria absolvido. Por fim, declarada a inocência, Amâncio foi carregado "em triunfo nos ombros dos colegas, entrou no hotel ao som do grande hino, chorando de emoção e agitando freneticamente o seu velho chapéu de feltro, desabado e boêmio"124.

Tanto nos relatos apresentados pelos jornais quanto no desfecho da intriga do romance, o julgamento e a absolvição dos estudantes geraram grande expectativa e comoção de parcela significativa da sociedade carioca. No livro, depois da sentença favorável a Amâncio:

Os estudantes formigavam assanhados como se acabassem de ganhar uma vitória. O nome do nortista [Amâncio] era repetido com transporte; um grupo enorme de rapazes, capitaneado pelo Paiva Rocha [seu conterrâneo] e pelo Simões [amigo do antagonista Coqueiro], aguardava o colega à saída do júri, para o conduzir em triunfo ao Hotel Paris, onde havia à sua espera um almoço e a banda de músicos alemães (CP, 1977, p. 181).

Embora houvesse grande festa em torno de Amâncio, na qual os estudantes da escola Politécnica e de Medicina comemoravam a absolvição do colega, por outro lado, Coqueiro via-se fracassado. Depois de sair do tribunal, ele isolou-se na casa de pensão, atormentado pela idéia de ter perdido a batalha, e envergonhado por não ter honrado a irmã. Nesses momentos, vinham-lhe em mente pensamentos dolorosos, afinal: “- Que faria agora de uma irmã prostituída, e de uma mulher desesperada?!..."125. Foi então, que movido por um impulso, decidiu pegar o revólver que foi do seu pai, primeiro pensou em dar cabo à própria vida, ridícula. Mas, antes

\footnotetext{
${ }^{124}$ CP, 1977, p. 181.

${ }^{125}$ Ibidem, p. 184.
} 
que tal delírio se concretizasse, ouviu vozes de estudantes que, ao retornar da festa comemorativa pela vitória de Amâncio, resolveram insultar Coqueiro e Amélia. "João Coqueiro presenciara tudo aquilo, grupado a um canto da janela, mordendo os nós da mão, os olhos injetados, o sangue a saltar-lhe nas veias. [...] - Se Amâncio estivesse ali, naquela ocasião, por Deus, que o estrangulava!"126. Deixando-se guiar pela ira, foi ao Hotel Paris e assassinou Amâncio à queima-roupa, até deixar a arma vazia.

Se esse mesmo desfecho for analisado sob a perspectiva dos relatos jornalísticos, podemos encontrar semelhança no posicionamento dos irmãos que processaram os jovens que se envolveram com Amélia e Júlia. Em 1884, a ficção dialoga com o caso jurídico ocorrido em 1876, quando Capistrano foi absolvido. Portanto, assim como Coqueiro, Alexandre Pereira não poderia aceitar esse final à desonra da irmã. Essa revolta se deve ao fato de que, na sociedade brasileira desse período, o corpo feminino estava sob cuidado e responsabilidade de seus genitores. Como Júlia e a personagem Amélia não tinham pai, o desfloramento sofrido ia além do limite de seus corpos, pois atingia seus responsáveis, isto é, Alexandre Pereira e João Coqueiro. Nesse ano de 1876, encontrava-se ainda em vigência o Código Criminal de 1830, no qual constava que as ofensas sexuais eram consideradas "crime contra a segurança da honra e honestidade das famílias", mantendo-se sob o capítulo dos "crimes contra a segurança da honra e honestidade das famílias e do ultraje público ao pudor" no Código Penal dos Estados Unidos do Brasil, publicado em 1980, ano da Proclamação da República. Por outro lado, apesar de a lei estabelecer subsídios para assegurar a honra das famílias, o comportamento do agressor poderia ser considerado, assim como possibilitou a Capistrano e Amâncio a absolvição:

[...] ao ser julgado um crime de defloramento, estupro ou atentado ao pudor, resultante da quebra de uma norma jurídica sexual, emergiam os valores sociais mais amplos da sociedade, pois eram também na quebra de outras normas morais e sociais que se determinava a absolvição e condenação do réu. Ou seja, a conduta total do indivíduo é que iria, ou não, redimi-lo de um crime; não estava em pauta apenas o que havia sido feito, mas aquilo que o acusado e a ofendida eram, poderiam ser ou seriam (ESTEVES, 1989, p. 41).

\footnotetext{
${ }^{126}$ Ibidem, p. 187.
} 
O paralelo entre ficção e realidade e o eixo temático comum evidenciam que o recorte final de Casa de Pensão parafraseia com o drama ocorrido em 1876, sem, com isso, representar uma cópia deste. Essa hipótese se fundamenta em dois argumentos. Em primeiro lugar, destaca-se que a literatura naturalista, difundida pelo mestre Zola (1995, p. 10), estabelece que: "Cada romance descreve a mecânica humana em funcionamento". Em segundo lugar, ao analisar o drama supracitado, Aluísio teve a oportunidade de observar os efeitos que esse acontecimento causou naqueles que o acompanharam, além de ter a oportunidade de tomar notas e, talvez, "entrevistar" protagonistas e testemunhas desse drama.

Da mesma forma que, para escrever Germinal, Zola morou em cortiços e observou o comportamento de trabalhadores de uma mina de carvão por meses, a fim de conhecer certos tipos de pessoas e seus comportamentos para, depois, escrever seu romance, Aluísio hospedou-se em casas de pensão e observou como era o cotidiano nesses ambientes. Azevedo infiltrava-se em ambientes propícios para anotar informações, diálogos e costumes de pessoas que iria pincelar em suas personagens, uma vez que ele "sabe dizer o que viu" (DUARTE, 1884, p. 314).

A partir desses exemplos, podemos levantar uma hipótese sobre as intenções do escritor naturalista: apresentar o mecanismo da vida em casa de pensão, permeada por vícios, jogo de interesse, falsidade e intriga. A nota Antes de principiar (1883) revela que Azevedo tinha plena consciência dos efeitos que a ficção poderia causar na mente dos leitores, que, a exemplo dele, leram ou acompanharam o desenrolar do drama íntimo apresentado por jornais cariocas de grande circulação.

O contexto do processo de criação confere a Aluísio a possibilidade de atribuir dupla natureza do modelo artístico. Isso é realizado quando o romance-seriado e, posteriormente, o livro, ao reproduzir um acontecimento particular, passam a espelhar uma imagem do mundo. Nesse sentido, Casa de Pensão configura-se como retrato de um microcosmo da sociedade carioca, ao mesmo tempo em que representa dramas que abalavam, de um modo geral, a sociedade contemporânea à ficção. Portanto, ao retratar o destino trágico de Amâncio, a diegese apresenta uma narração sobre a tragédia do mundo em seu conjunto (LOTMAN, 1978, p. 358).

Seguindo o percurso de produção, concebemos essa história como um romance de crítica social. A estratégia de verossimilhança adotada por Aluísio Azevedo é semelhante àquela utilizada em reportagens, o que se justifica pela escolha do pano de fundo ou pela descrição de hábitos e costumes. Por essas 
razões, os personagens referenciam pessoas envolvidas em um drama, em uma construção mimética. Ao utilizar a palavra verdade, Aluísio elabora retratos fiéis do cotidiano com o realismo do cenário e das situações. O estilo híbrido empregado no plano estético do romance encontra-se também no plano das intenções do autor. Aluísio desenvolve em Casa de Pensão uma tese de caráter sociopolítico ao mesmo tempo em que faz descrições de cenas irreais e fantásticas.

Enquanto diferentes leitores, em diferentes momentos, possuem expectativas diversas, uma pequena parcela de leitores tem a possibilidade de associar expectativa e experiência na recepção do romance. Nesse aspecto, a ficção tem o poder de cristalizar acontecimentos, como um registro histórico, sob o ponto de vista de quem o contou. E, assim, a sociedade carioca, retratada na ficção, identificou o tempo histórico da narrativa graças às vozes vindas da memória. Contudo, a distância temporal do fato que inspirou o romance não impede que essas vozes possam ser ouvidas nas entrelinhas da ficção, ou seja, à medida que os leitores de diferentes épocas têm acesso a informações sobre a origem do romance e ao processo criativo da obra, o horizonte do texto também se abrirá ao contexto.

Nos dois episódios, as leituras de cenas do cotidiano seguem a ordem apresentada por Jobim (1992, p. 48), em que o jornal, que chega primeiro, pode recolher e dramatizar os fragmentos da realidade, e o livro, que chega depois, é uma segunda operação de tiragem e de transformação do material semi-acabado do jornal. Nesse sentido, numa classificação clássica dos gêneros, o jornalismo deveria entrar entre a épica e o drama, entre a narração dos fatos e a ação entre os homens (LIMA, 1990, p. 58).

\subsection{Romantismo, Naturalismo e o híbrido}

As inúmeras transformações ocorridas na década de 1880, época em que Aluísio consolidou-se como escritor, não foram suficientes para romper completamente com a tradição romântica e, dessa forma, constrói-se o "hibridismo" da obra aluisiana, refletindo, concomitantemente, o passado ainda latente e o novo que se impõe. De um lado, estava o passado, balizado pela teoria econômica escravista colonial e ligado a uma dimensão romântica idealizadora e conservadora; 
do outro lado, o presente, impulsionado pela teoria econômica liberal, com os ideais de democracia que dominou parte da Europa, no século XVIII, e associado ao cientificismo, sob a bandeira do Naturalismo. Apesar das mudanças, a estrutura sociocultural continuou pautada pelo ranço do autoritarismo e resistente à renovação. A literatura brasileira, por sua vez, vivia dois dilemas antagônicos, por um lado procurava conservar o Romantismo para agradar os leitores, por outro, viase impulsionada a introduzir o Naturalismo para atender às exigências da crítica.

Diante desse impasse, construiu-se o duplo horizonte literário em torno de romances publicados no início da década de oitenta do século XIX. A linguagem "híbrida", otimizada por Aluísio Azevedo, reflete a harmonia entre Romantismo e Realismo na base estrutural da Literatura Brasileira, desse período. Casa de Pensão, por exemplo, fixa um momento de transição e definição de novas perspectivas para o discurso literário. Desse modo, embora exista o caráter antagônico do Romantismo e do Naturalismo, ambos podem conviver no interior do mesmo enunciado romanesco, apesar de que um aponte para o passado e outro para o futuro, um aponte para dentro do texto e ou outro para dentro da vida.

É com o status de verdade, declarado na nota Antes de principiar (1883), no sentido positivista da história, que se levanta a ficção em análise. Ao inserir registros jornalísticos e uma perspectiva histórica no romance, tendo em vista os propósitos da ficção, Aluísio Azevedo demonstra habilidade de armazenar, em Casa de Pensão, índices do passado, caracterizando-os como um episódio de nossa história, extraído do cotidiano carioca, que passava por grandes transformações, na década que antecedia à Proclamação da República.

O desenvolvimento social e tecnológico crescente no final do século XIX revela que: "O caminho de Aluísio Azevedo para o romance da coletividade é a ampliação da imaginação da vida orgânica no sentido de maior complexidade de organismos". Destacamos, também, que o autor acompanha essa evolução na medida em que não apresenta apenas "o homem só contra os preconceitos do meio e da hereditariedade de O Mulato, O Homem, O Coruja", pois: "A pequena comunidade de Casa de Pensão prenuncia a comunidade de O Cortiço" (BRAYNER, 1973, p. 41).

Ao realizar um retrato de mundo graças à reunião de modalidades artísticas combinadas em Casa de Pensão, o sucesso do romance-seriado compartilha do sucesso adquirido pelo drama narrado pelo Jornal do Comércio e pela Gazeta de 
Notícias; a dimensão desse acontecimento é ampliada com o aparecimento da versão em livro, em função dos propósitos comunicativos do autor com seus interlocutores, com o intuito de atingir um público mais amplo, especializado, sem deixar de citar o retorno financeiro.

Segundo Sodré (1992, p. 192), no contexto sociocultural no qual se desenvolveu o Naturalismo: "Os acontecimentos artísticos são marcados pelo público e não pelo autor; pela aceitação e não pela invenção". Ao assistir as mudanças ocorridas no Brasil do século XIX, Aluísio preocupou-se em focar alguns microcosmos que retratassem os efeitos dessas transformações, como quem olha pelo buraco de uma fechadura, ou ouve diálogos do povo. Ao infiltrar-se nos espaços, que seriam transformados em cenário, e convivendo com pessoas, que, posteriormente, poderiam ser tipificadas em seus romances, o escritor conseguia entender os temas que eram de interesse do público e que acontecimentos poderiam ser romanceados.

Em continuidade, Sodré (1992, p. 215-216) destaca que Casa de Pensão não é apenas "um de seus melhores romances, mas é aquele que traz a marca inconfundível do processo naturalista". Essa constatação parte do pressuposto de que Aluísio Azevedo seguiu a método utilizado por Zola, ao mergulhar no recorte de mundo com o qual iria dialogar na ficção e, além disso, foi autêntico ao enfocar temas nacionais.

Também não podemos deixar de citar que, como o percurso criativo de Casa de Pensão apresenta traços de maleabilidade do gênero, é possível constatar que o âmbito textual absorve marcas de uma dimensão intertextual, produzindo relações intragenéricas e/ou intergenéricas. Como conseqüência da linguagem dialógica, expressa em Casa de Pensão: o romance se remete a textos de gêneros diferentes, primários ou secundários, relacionados à Questão Capistrano, com os quais interage intertextualmente. Como exemplo de relação intergenérica (textos que não pertencem ao mesmo gênero), no processo intradiscursivo do romance focado neste estudo, podemos citar os diversos textos publicados no Jornal do Comércio e na Gazeta de Notícias, que descrevem os pormenores do julgamento, da absolvição e do posterior assassinato de Capistrano da Cunha, como registro da comoção que esse drama causou na população carioca do período.

A mistura de gêneros adotada como recurso literário no processo composicional do romance Casa de Pensão é marca do hibridismo discursivo, do 
Romantismo ao Naturalismo, como característica da poética em transitoriedade, apontando a plasticidade da escrita de Aluísio Azevedo. Se, por um lado o autor preocupa-se em manter os leitores já conquistados, por outro, também se preocupava com a crítica do período.

Da mesma forma que o escritor pôde escolher pelo híbrido na definição de modo narrativo, também Ihe foi dada a opção de moldar os personagens a partir da dupla natureza que representam. A natureza ambígua carrega vozes que se remetem ao jornalismo e se misturam à literatura; o gênero transita entre o Romantismo e o Naturalismo. De um lado os personagens são descritos através da lente naturalista; na luta pela sobrevivência; na vitória dos mais fortes e aptos; nos aspectos doentios da sociedade carioca retratada no romance; no mercado matrimonial, entre outros. Por outro lado, o personagem Amâncio é guiado pelas fantasias românticas; na imagem que o protagonista faz da mãe, um anjo; na idealização de Hortênsia, que apenas é desejada enquanto é incessível; na reminiscência ao byronismo da entrega aos vícios, à bebida e ao sexo; no nacionalismo latente na figura do maranhense Amâncio, o autor faz exaltação à Pátria, o Maranhão, dentre outros aspectos. Essas escolhas contribuem para a caracterização dos personagens, que incorporam traços expressivos, que, por sua vez, são incorporados aos demais elementos narrativos. Portanto:

\begin{abstract}
A personagem é um ser fictício, - expressão que soa como um paradoxo. De fato, como pode uma ficção ser? Como pode existir o que não existe? No entanto, a criação literária repousa sobre este paradoxo, e o problema da verossimilhança no romance depende desta possibilidade de um ser fictício, isto é, algo que, sendo uma criação de fantasia, comunica a impressão da mais lídima verdade existencial. Podemos dizer, portanto, que o romance se baseia, antes de mais nada, num certo tipo de relação entre o ser vivo e o ser fictício, manifestada através da personagem, que é a concretização deste ${ }^{127}$.
\end{abstract}

Como a natureza híbrida cerca diversos campos composicionais, é difícil classificar cada elemento por seu mote de origem, ou diferenciá-los entre si. Por esses aspectos, Casa de Pensão de Aluísio Azevedo é uma obra de caráter híbrido, de forma inovadora e valor inquestionável, representando um fenômeno cultural que une texto e contexto e atribui historicidade a um texto literário.

\footnotetext{
${ }^{127}$ CANDIDO, Antonio. A personagem do romance. In: CANDIDO, Antonio (Org.). A Personagem de
} Ficção, cit. p. 55. 
Considerado por muitos críticos como papa do Naturalismo brasileiro, Aluísio foi um escritor profissional que, segundo Ramalho Ortigão, fez da literatura seu "ganha pão", sem garantir a manteiga. Se no teatro e na poesia não obteve êxito, seu primeiro talento artístico, as artes plásticas, conferiu-lhe a possibilidade de pintar quadros da sociedade maranhense e carioca. Pintor, ficcionista de peso, homem do jornal no Maranhão, sua terra natal; da caricatura e do romance-seriado em periódicos cariocas, consideramos que Aluísio fixou-se na história da Literatura Brasileira como um dos principais expoentes do seu tempo por seguir a tipologia do romance moderno do século XIX. O universo representativo do romance permite que, mais de um século transcorrido desde a aparição do romance-seriado Casa de Pensão, seja possível visualizar na diegese desse romance um verdadeiro quadro da sociedade brasileira, vista pela lente de um jornalista literato. 


\section{CONCLUSÃO}

As duas variantes do romance analisado têm como eixo temático a vida em casa de pensão, caracterizada pelo comportamento de tipos que representam seus habitantes. Tanto no recorte dos primeiros onze capítulos do romance-seriado, quanto em sua formatação em doze capítulos e a hipertrofia da intriga, que totaliza vinte e dois capítulos na versão em livro, as diferenças estruturais e de repertório semântico representam elementos que nos conduzem à constatação da habilidade que Aluísio possuía para entender a mudança de perspectiva que se vinculava ao gênero de publicação. Se ultrapassarmos os limites do romance-seriado e focarmos a narração do inquérito na versão em livro, constataremos que as analepses centram-se no personagem Amâncio, do mesmo modo que o discurso noticioso centrou-se em Capistrano, que é indiciado por Alexandre Pereira, sob a acusação de abuso sexual.

Enquanto a técnica narrativa do romance-seriado de "conduzir para trás" (RIBEIRO, 1996, p. 45) pode ser constatada nos primeiros segmentos de Casa de Pensão, os primeiros capítulos do livro apresentam grandes analepses (GENETTE, 1995). Nas duas variantes, esse descompasso do ritmo narrativo é guiado pelo fluxo de consciência de Amâncio, por meio do qual são narrados pormenores de acontecimentos que marcaram a infância do personagem. No desenvolvimento narrativo, os recuos temporais desaparecem à medida que as ações de Amâncio se direcionam ao espaço do Rio de Janeiro. No entanto, o cronótopo de Casa de Pensão preserva os fatores responsáveis pela formação do caráter de Amâncio, de suas atitudes hipócritas e dissimuladas, que explicam a propensão que o protagonista tinha para a transgressão às normas sociais.

Embora o narrador seja onisciente nas duas variantes, apenas no romanceseriado ele apresenta, com riqueza de detalhes: os amores que Amâncio teve na adolescência, os quais indicam a inclinação que o protagonista tinha para aventurarse em amores proibidos; o fato de Coqueiro ter ganhado uma pistolinha do pai na infância aponta para a familiaridade que o antagonista tinha com armas de fogo; a tentativa de Amélia libertar-se do projeto matrimonial idealizado para ela também pode ver evidenciada no romance-seriado. Nesses dois últimos exemplos, pode ser 
identificado o cruzamento de vozes das personagens e seus modelos: Coqueiro/Pereira e Amélia/Júlia, ao passo que o discurso narrativo é conduzido pelo narrador, por intermédio do discurso indireto livre.

As descrições ricas em detalhes e os finais das seqüências com gancho instauram unidades de ação a cada segmento narrativo, conferindo suspense e expectativa quanto à continuidade da história. $O$ corte repentino quebra o ritmo narrativo e interrompe as ações. Nesse discurso que sofre mutações e se aprimora na versão em livro, a técnica narrativa com os "lances teatrais" revela dois modos de representação, nos quais os personagens têm suas linhas de ações quebradas e se reformulam por intermédio de diálogos, como marca da oralidade, o que é mais enfático no romance-seriado.

Tanto no romance-seriado quanto no livro, o "didatismo narrativo" retoma episódios interrompidos por outras ações e, assim, os núcleos são desenvolvidos em meio a técnicas comuns às duas versões, porém, apenas no livro, as soluções são reveladas na medida em que a narrativa se encaminha para a intriga.

A narrativa apresenta a casa de pensão personificada, como um monstro, que assusta a população e assiste à doença de Amâncio. Limitados ao espaço fechado, os hóspedes têm suas vidas aprisionadas e a disseminação dos vícios torna-se oportuna. Essa analogia feita à casa de pensão remete à técnica narrativa da "verossimilhança que nunca escorrega para o irracional [...]", porque a mesma casa de pensão que assustava a população, também ressuscitava o cenário da Questão Capistrano. No livro, a dilatação do espaço transfere os personagens para Santa Teresa, onde a saúde de Amâncio é restabelecida. Depois desse acontecimento, o romance de Amélia e Amâncio concretiza-se, e a irmã de Coqueiro pressiona o maranhense para mudarem-se para um chalé, justificando que a disposição dos quartos, com ligações internas, daria mais liberdade para os amasiados em seus encontros noturnos.

A organização estrutural dos segmentos é reformulada e os capítulos sofrem alterações de ordem organizacional. Os onze capítulos do romance-seriado são revidados para a publicação do livro e compreendem os doze primeiros capítulos do livro.

Veiculada à poética do escritor, nas duas variantes, a caracterização dos personagens é realizada por intermédio de linguagem plástica. Como se Aluísio visualizasse Amâncio e os personagens a ele relacionados sobre sua escrivaninha; 
o escritor atribui movimento às ações, ora lançando-os para dentro das aventuras de romances românticos, ora atribuindo-Ihes máscaras criadas à atuação em sociedade e obtenção de seus propósitos. Ao lado das peripécias que envolvem os personagens, com maior visibilidade estão aqueles para os quais a voz não é dada, como sinal de preconceito ou símbolo de franqueza, que reduz os seres. O escravo Sabino e Pereira, marido de Lúcia, e a histérica Nini, por exemplo, vivem no subsolo narrativo e têm suas vidas limitadas ao que outros façam por elas.

A descrição caricata é aprimorada no livro, destacando o emprego da técnica narrativa do romance-seriado, da descrição do vilão com traços grosseiros e satânicos, o que ressalta o diálogo dos gêneros e a intensificação do discurso naturalista. Na medida em que o desfecho revela os vencedores e perdedores, a sensação de fracasso estimula o emprego de características zoomorfizantes à descrição de Coqueiro, antagonista do romance.

A análise dos núcleos narrativos não publicados no romance-seriado evidencia que o autor preservou grande parte das técnicas utilizadas na versão destinada para o jornal, o que demonstra um diálogo das duas versões e com o contexto criativo.

Nas duas etapas criativas, a ficção retrata um microcosmo da sociedade carioca, representado por personagens inspiradas no drama, a fim de mostrar "a mecânica humana em funcionamento". As duas etapas de publicação caracterizamse como documentos para a compreensão do processo criativo. Enquanto a primeira versão revela o que impulsionou o escritor a definir os elementos ligados ao romance, na descrição dos personagens, espaço, tempo, enredo e apresentação do tema, a segunda mostra que por trás do texto há um escritor-revisor, preocupado em preparar o livro para atingir ampla circulação.

$\mathrm{Na}$ organização textual, o narrador onisciente revela os pensamentos dos personagens e as ações deles resultantes. Amâncio de Vasconcelos é o fio condutor da narrativa e ao mesmo tempo assume o papel de vítima dos próprios erros, evidenciando que em sua voz há muito de Capistrano. A intercessão de linguagens, jornalística e literária, no romance-seriado e em livro, evidencia uma das características do processo criativo de Aluísio Azevedo, que denota sua habilidade de atender às exigências do mercado editorial, ao mesmo tempo em que revela sua sensibilidade para entender o impacto que o romance moderno poderia provocar sobre os indivíduos. 
Susana Rotker (1991) optou pelo estudo das crônicas de José Martí (1853-95) pelo fato de encontrar, nesse gênero, um modo de entender a escritura do escritor cubano. Assim como cada autor, cada época tem sua linguagem, Martí e os modernistas de seu grupo criaram uma nova prosa na América Hispânica. Nessa perspectiva, ao definir a representatividade de temas ligados ao texto derivado de notícias, Rotker (1991, p. 252) destaca que: "A crônica, como o jornalismo, não inventa os feitos que retrata; mas sua maneira de reproduzir a realidade é outra".

Contemporâneo de Martí, Aluísio Azevedo (1857-1913) esteve presente no espaço concreto da cidade do Rio de Janeiro, nas décadas de 1870-1880, por essa razão lhe foi possível conferir à narrativa de Casa de Pensão laços que estabelecem essa relação por intermédio do texto. O lugar ocupado por Aluísio favoreceu essa participação, do mesmo modo que pode contribuir para o registro dos modos de agir e de pensar da população responsável por algumas das vozes presentes no discurso ficcional, caracterizadas pela presença do aspecto popular na cultura, contribuindo, assim, para a potencialidade do social em Casa de Pensão. A partir dessa constatação, podemos pressupor que os dois modos de representar e apresentar o romance são formas de acompanhar o movimento midiático, ao mesmo tempo em que procura atingir as expectativas dos leitores e críticos.

Atento às transformações decorrentes do efeito da tecnologia sobre os indivíduos, Aluísio Azevedo encontrou, nas notícias da Questão Capistrano (1876), uma oportunidade de dialogar com valores e posicionamentos dos leitores, em função do efeito que o drama causou sobre aqueles que acompanharam o desenrolar desse episódio, a partir das descrições apresentadas pelo Jornal do Comércio e pela Gazeta de Notícias. Por um lado, encontramos, no romanceseriado, a nota Antes de principiar, na qual Aluísio se dirige ao público contemporâneo a essa publicação, expondo os motivos e objetivos que o levaram à criação desse romance, do mesmo modo em que pede desculpas se os efeitos provocados com a leitura desagradar os que o lêem. Por outro lado, a versão em livro representa a conclusão do projeto que fora descrito na nota Antes de principiar, na véspera da publicação da primeira fatia de Casa de Pensão, ao mesmo tempo em que revela o ponto de vista do escritor naturalista sobre a Questão Capistrano, aludida na história do romance.

Como há aspectos culturais apresentados no mecanismo que traduz plasticidade às duas versões de Casa de Pensão, esses textos compreendem 
sistemas de signos, como síntese de unidades mínimas de um recorte cultural, cuja organização interna definida, preserva seus traços distintivos, embora possam gerar novos significados. Nesse aspecto, "cultura é memória, ela relaciona-se necessariamente com a experiência histórica passada. [...] A própria existência da cultura pressupõe a construção dum sistema de regras para a tradução da experiência imediata em texto" (LOTMAN; USPENSKI, 1981, p. 41).

De acordo com Martín-Barbero:

O folhetim [francês] fala do popular-urbano: sujo e violento, o que geograficamente se estende desde o subúrbio até a penitenciária, passando pelos hospícios e as casas de prostituição. (...) Além de divórcios e adultérios, há incestos e abortos, mães solteiras e operárias seduzidas por patrões, dos quais se vingam cruel e fatalmente. Existe moralismo, mas também ligação entre a repressão sexual e as condições sociais de vida. $O$ universo operário que aí aparece é o de um proletariado sem consciência de classe - mas quantos romances tinham, antes, tematizado esse universo de miséria, do medo e da luta pela sobrevivência? (MARTíN-BARBERO, 2001, p. 199).

Seguindo a tendência do romance-seriado francês, Aluísio desnuda comportamentos pretensiosos, movidos pelo jogo de interesses que movem os seres humanos. Os vícios arrancam Amâncio do aconchego da mãe e o arremessam para duas arapucas matrimonias; o sexo é a moeda de troca utilizada por Amélia, enquanto o casamento não se concretiza, por fim, sua virgindade é perdida e Amâncio é assassinado por Coqueiro, que, por ironia do narrador, torna-se herói depois de ter honrado a irmã.

O movimento criativo de Casa de Pensão revela a habilidade de Aluísio Azevedo de se destacar na prática de uma tendência em voga no século XIX. Ao unir jornalismo e literatura para escrever uma espécie de crônica do cotidiano, o escritor revela grande capacidade criativa de conferir plasticidade à linguagem utilizada no romance cotejado neste estudo. 


\section{REFERÊNCIAS}

A CIGARRA. Fantasio. Rio de Janeiro, 01 ago. 1895. p. 2.

A BAGAGEM. Casa de pensão. Bagagem - Minas Gerais, 04 dez. 1884 - 08 out. 1885.

AGUIAR E SILVA, Vitor Manuel de. Teoria da literatura. 5 ed. Coimbra: Livraria Almedina, 1983. V. 1.

ALBÉRÈS, René Marill. Histoire du roman moderne. Paris: Éditions Albin Michel, 1962.

ARARIPE JR. Obra crítica de Araripe Júnior. V. I (1868 - 1887). Rio de Janeiro:

Casa de Rui Barbosa - Centro de Pesquisa, 1958.

. Obra crítica de Araripe Júnior. V. II (1888 - 1894). Rio de Janeiro: Casa de Rui Barbosa - Centro de Pesquisa, 1960.

AZEVEDO, Aluísio. Casa de pensão. Folha Nova: Rio de Janeiro, 08 mar. 1883 - 22 maio 1883.

. Casa de pensão (Ed. Popular). Rio de Janeiro: Faro \& Lino, 1884.

. Casa de pensão. Rio de Janeiro. São Paulo: Ática, 1977.

. Fora de horas. In: Demônios. Rio de Janeiro: Granier, 1894. p. 130.

. Filomena Borges. Gazeta de Notícias: Rio de Janeiro, 11 out. 1883 - 16 fev. 1884.

- Girândola de amores (romance-seriado: Mistérios da Tijuca) Rio de Janeiro: F. Briguiet, 1939.

. Mistério da Tijuca. Folha Nova: Rio de Janeiro, 23 nov. 1882 - 18 fev. 1883. 
. O homem. Rio de Janeiro: Adolfo de Castro Silva, 1887, p. 1.

. O touro negro. São Paulo: Martins Editora: 1961.

BAKHTIN, MIKHAIL MIKHAILOVITCH. Gêneros do discurso. In: Estética da criação verbal. São Paulo: Martins Fontes, 1992.

. Questões de literatura e de estética (A teoria do romance). 4 ed. São Paulo: Editora da UNESP, 1998.

BEVILAQUA, Clóvis. Epochas e Individualidades: estudos literários. 2 ed. Rio de Janeiro: Garnier, 1988.

BILAC, Olavo. Crônica livre. Gazeta de Notícias. Rio de Janeiro, 17 out. 1893.

BOSI, Alfredo. Araripe Júnior: Teoria, Crítica e História Literária. Rio de Janeiro: Livros Técnicos e Científicos; São Paulo: Edusp, 1978. p. 139.

As fronteiras da Literatura. In: Flávio Aguiar et al. Gêneros de fronteira. São Paulo: Xamã, 1997.

. História concisa da literatura brasileira. São Paulo: Cultrix, 1994.

BRAYNER, Sonia. A metáfora do corpo no romance naturalista. Rio de Janeiro: São José, 1973.

. Labirinto do espaço romanesco. Rio de Janeiro: Civilização Brasileira, 1979.

BRUNETIĖRE, Ferdinand. Le roman naturaliste. Paris: Calman-levy, 1883.

CABRAL, Isabel Cristina Martelli; MINCHILLO, Carlos Alberto Cortez. A Narração: teoria e prática. São Paulo: Atual, 1991. p. 27-28.

CASTELLO, José Aderaldo. A literatura brasileira: origens e unidade (1500-1960). V. I. São Paulo: Edusp - Editora da Universidade de São Paulo, 1999.

CANDIDO, Antonio. Literatura e sociedade. São Paulo: Editora Nacional, 1965. 
CANDIDO, Antonio. A personagem de ficção. 8 ed. São Paulo: Perspectiva, 1998.

DANTAS, Paulo. Aluísio Azevedo. O romancista do povo. São Paulo: Melhoramentos, 1954.

DIJK, Teun A. Van. La noticia como discurso: comprensión, estructura y producción de la información. Barcelona: Paidós, 1990.

DOSTOIEVSKI, Fiodor Mikhailovitch. Memórias do subsolo. Tradução Boris Schnaiderman. São Paulo: Paulicéia, 1992.

ESTEVES, Martha de Abreu. Meninas perdidas: os populares e o cotidiano do amor no Rio de Janeiro da Belle Époque. Rio de Janeiro: Paz e Terra, 1989.

FILHO, Mello Barreto; LIMA, Hermeto. História da polícia do Rio de Janeiro. V. 3. Rio de Janeiro: A Noite, 1942. p.128.

FONSECA, Gardin. Biografia do jornalismo carioca. Rio de Janeiro: Quaresma, 1941.

FOUCAULT. A mulher os rapazes: História da sexualidade. V. 3. Rio de Janeiro: Paz e Terra, 1997.

FRANCASTEL, Pierre. 1968. Esthétique et Ethnologie. In: J. Poirier (ed.), Ethnologie Générale. Encyclopédie de la pléiade (vol. XXIV). Paris: Gallimard. pp. 1706-1729.

GADAMER, Hans-Georg. Verdade e método. Petrópolis, Vozes, 1997.

GARGUREVICH, Juan. Gêneros periodisticos. Quito: Belén, 1982.

GAZETA LITERÁRIA. Casa de pensão. Rio de Janeiro, 10 ago. 1884 n.16, p.313315.

GAZETA DE NOTÍCIAS. Notas à margem: da Casa de pensão. Rio de Janeiro, 3, 5, 12 e 13 jul. 1884 , p. 1.

GAZETA DE NOTÍCIAS. O acontecimento do dia (Questão Capistrano). Rio de Janeiro, 20 nov. 1876. p. 1. 
. João Capistrano. Rio de Janeiro, 21 nov. 1876. p. 1.

GENETTE, Gérard. Discurso da narrativa. Tradução Fernando Cabral. Lisboa: Veja, 1995.

GRANDO, Marizete Liamar. O Processo de produção ficcional do romance Casa de pensão. São Paulo. 2004. Dissertação (Mestrado em Literatura Brasileira) Faculdade de Filosofia, Letras e Ciências Humanas - Universidade de São Paulo FFLCH/USP.

IBGE. Censos demográficos 1872 e 1890. Dados extraídos de: Estatísticas do século XIX. Disponível em: http://biblioteca.ibge.gov.br/visualizacao/monografias/visualiza_colecao_digital.php?ti tulo=Recenseamento\%20Geral\%20do\%20Brasil\%201872\%20\%20Imp\%C3\%A9rio\%20do\%20Brazil\&link=Imperio\%20do\%20Brazil. Acesso em: 12 fev. 2007.

ISER, Wolfgang. A interação do texto com o leitor. In: JAUSS et al. A literatura e o leitor: textos de estética da recepção. Coordenação e tradução Luiz Costa Lima coleção Literatura e teoria literária. V. 36. Rio de Janeiro: Paz e Terra, 1979. p 50.

JAKOBSON, Roman. Essais de Linguistique Générale. Paris: Les Éditions de minuit, 1970.

JAUSS, Hans Robert. A História da literatura como provocação à teoria literária. Tradução Sergio Tellaroli. São Paulo: Ática, 1994.

JOBIM, Danton. Espírito do Jornalismo. São Paulo: Edusp: Com-Arte, 1992.

JORNAL DAS FAMÍLIAS. Tomo 16, jul. 1878, p. 211-216. Disponível em: <http://www.caminhosdoromance.iel.unicamp.br/biblioteca/0212/index.htm>. Acesso em: 25 jul. 2008.

JORNAL DO COMÉRCIO. Jury. Rio de Janeiro, 18 nov. 1876. p. 3.

JORNAL DO COMÉRCIO. Processo Capistrano. Rio de Janeiro, 19 nov. 1876, p. 2. 
JORNAL DO COMÉRCIO. Assassinato. Rio de Janeiro, 20 nov. 1876, p.1.

JORNAL DO COMÉRCIO. Assassinato Capistrano. Rio de Janeiro, 21 nov. 1876, p. 3.

JORNAL DO COMÉRCIO. Questão Capistrano. Rio de Janeiro, 22 nov. 1876. p. 2.

JÚNIOR, Raimundo Magalhães. Olavo Bilac e sua época. Rio de Janeiro: Americana, 1975. p. 146-156.

LIMA, Alceu Amoroso. 0 jornalismo como gênero literário. São Paulo: Com Arte, Edusp, 1990.

LLOZA, Mario Vargas. Cartas a um novelista. Barcelona: Editorial Ariel S.A., 1997. p. 63.

LOTMAN, luri. A estrutura do texto artístico. Editora Estampa: Lisboa, 1978.

. La semiosfera. Tradução Desidério Navarro. Madrid: Ediciones Cátedra, 1996.

LOTMAN, luri e Bóris USPENSKII. Sobre o Mecanismo Semiótico da Cultura. In: Ensaios de semiótica soviética. Lisboa: Livros Horizontes, 1981.

MARTÍN-BARBERO, Jesús. Dos meios às mediações: comunicação, cultura e hegemonia. 2. ed. Rio de Janeiro: Ed. UFRJ, 2001.

MACLUHAN, Marshall. Os meios de comunicação como extensões do homem. São Paulo: Cultrix, 1964.

MAGALHÃES JÚNIOR, Raymundo. Olavo Bilac e sua época. Rio de Janeiro: Editora Americana, 1974.

MAGALHÃES, Valentim (1889). Escritores e Escritos (perfis literários e esboços críticos). Rio de Janeiro: Domingos de Magalhães editor, 1894.

MENEZES, Raimundo de. Aluísio Azevedo, uma vida de romance. São Paulo: Livraria Martins, 1958. 
MÉRIAN, Jean-Yves. Aluísio Azevedo, vida e obra (1857-1913): O verdadeiro Brasil do século XIX. Rio de Janeiro: Espaço e Tempo, 1988.

MOISÉS, Massaud. Historia da literatura brasileira: romantismo, realismo, parnasianismo. V. 2. São Paulo: Cultrix/Edusp, 1984.

MONTELLO, Josué. Aluísio Azevedo e a polêmica d'O Mulato. Rio de Janeiro: José Olympio, 1975.

Aluísio Azevedo: uma vida de romance. São Paulo: Martins Fontes, 1957.

MESZAROS, Istvan. A Teoria da Alienação. São Paulo: Boitempo Editorial, 2006, p. 38.

MEYER, Marlyse. Folhetim: uma história. São Paulo: Companhia das Letras, 1996.

MORIN, Edgar. Método 3 - o conhecimento do conhecimento. Lisboa: Publicações Europa - América, 1996.

NETO, Coelho. A conquista. Porto: Chardron, 1913.

O meu dia. Porto: Chardron, 1922, p. 105-106.

NOVIDADES. Eloy, o heroy [Artur Azevedo]. Do palanque. Rio de Janeiro, 3 out. 1887.

PELLEGRINI, Tânia. Narrativa verbal e narrativa visual: possíveis aproximações. In: et al. Literatura, cinema e televisão. São Paulo: Editora Senac, 2003.

O COMBATE. 12 de março de 1892. In: Azevedo, Aluísio. O touro negro. São Paulo: Martins Editora: 1961. p. 64.

O IMPARCIAL. Aluísio Azevedo: O que nos diz Coelho Neto. Rio de Janeiro, 25 jan. 1913. p. 07.

O MEQUETREFE. Casa de pensão. Sá Pinho. Rio de Janeiro, 30 maio 1883. p.6.

. Casa de pensão. k. Loiro. Rio de Janeiro, 10 jun. 1883. p. 07. 
. Casa de pensão. Rio de Janeiro, 20 fev. 1884. p. 6.

. Casa de pensão. Rio de Janeiro, 30 maio 1884. p. 5.

. Casa de pensão. Rio de Janeiro, 30 jun.1884. p. 6.

PONTES, Elói. A vida inquieta de Raul Pompéia. Rio de Janeiro: Olympio, 1935. p. 240-245.

PINHEIRO, Amalio. Jornal: cidade e cultura. In: Manuscritica 12: Revista de Crítica Genética. São Paulo: Editora Annablume, 2004.

RIBEIRO, José Alcides. Ficção brasileira e imprensa: um fenômeno inicial de linguagens em interface. In: Fragmentos de Cultura. Goiânia, Editora da Universidade Católica de Goiás, v.10, n.1, p. 163-180, jan./fev. 2000.

. Imprensa e ficção no século XIX. Edgar Allan Poe e a Narrativa de Arthur Gordon Pym. São Paulo: Editora UNESP, 1996.

RICOEUR, Paul. Interpretação e ideologias. Rio de Janeiro: Francisco Alves, 1990.

RICOEUR, P. Mundo do texto e Mundo do leitor. In: Tempo e Narrativa Vol. III, Campinas, editora Papirus, 1995.

RIO, João do. O movimento literário. Rio de Janeiro: Garnier, 1905. p. 10.

Michael Riffaterre. La Production du Texte, Seuil, Paris, 1979. p. 7ss.

Rotker, Susana: Fundación de una escritura. Las crónicas de José Martí. Cuba: Casa de las Américas, 1991.

SODRÉ, N. W. História da imprensa no Brasil. Rio de Janeiro: Civilização Brasileira, 1966.

SODRÉ, Nelson Werneck. O Naturalismo no Brasil. Belo Horizonte: Oficina de Livros, 1992. 
SUPLEMENTO LITERÁRIO DE A MANHÃ. Autores \& Livros (dedicado a Aluísio Azevedo). N. 11. Rio de Janeiro, 5 abr. 1942. p. 167-182.

SUSSEKIND, Flora. Tal Brasil, qual romance? Rio de Janeiro: Achiamé, 1984.

TERROU, F. \& ALBERT, P. História da imprensa. São Paulo: Martins Fontes, 1990

TODOROV, Tzvetan. Os gêneros do discurso. Lisboa: Edições 70, 1978.

VERÍSSIMO, José. José Veríssimo. Teoria, crítica e história literária. Rio de Janeiro: Livros Técnicos e Científicos; São Paulo, 1977.

VIVALDI, Gonzalo Martin. Géneros periodísticos. Madrid: Paraninfo, 1979.

ZOLA, Emile. Do romance. Tradução Plínio Augusto Coelho. São Paulo: Imaginário/Edusp, 1995. 